SOIL-WATER HYDROLOGY AND GEOCHEMISTRY OF A COAL SPOIL AT

A RECLAIMED SURFACE MINE IN ROUTT COUNTY, COLORADO

By Robert S. Williams, Jr., and Stephen E. Hammond

U.S. GEOLOGICAL SURVEY

Water-Resources Investigations Report 86-4350

Prepared in cooperation with the

U.S. BUREAU OF LAND MANAGEMENT

Denver, Colorado 1988

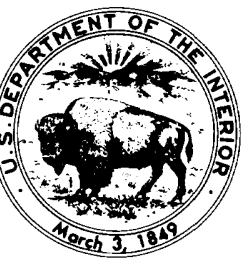


DEPARTMENT OF THE INTERIOR

DONALD PAUL HODEL, Secretary

U.S. GEOLOGICAL SURVEY

Dallas L. Peck, Director

For additional information write to:

District Chief

U.S. Geological Survey

Water Resources Division

Box 25046, Mail Stop 415

Federal Center

Denver, CO 80225-0046
Copies of this report can be purchased from:

U.S. Geological Survey

Books and Open-File Reports

Federal Center, Bldg. 810

Box 25425

Denver, CO 80225-0425 
Abstract-1.

Introduction-

Purpose and scope-1.

Acknowledgments

Previous work-10

Description of study area-

Description of instrumentation-

Lysimeters

Soil-water access tubes-

Neutron-probe calibration-

Periods and types of data collection-

Soil water-10

Comparison of sites-

Soil-water profiles-

Soil-water content at the undisturbed site-

Coal-spoil recharge--

Geochemistry-

Acceptance of chemical data-

Lysimeter leachate quality-

Dissolved-solids concentration-

Piper-trilinear diagram-

Sources of dissolved solids-

Atmospheric carbon dioxide, decay of organic matter, and

plant respiration-

Mineral weathering-

Summary and conclusions-

References cited---

Supplementary water-quality data-

Page

\section{FIGURES}

Figure 1. Map showing location of study area and the Piceance basin---

2. Map showing geology near the Seneca Mine--.-

3. Generalized columnar section of exposed rocks in parts of Routt and Moffat Counties.-.

4. Average monthly maximum and average monthly minimum temperatures at Hayden, Colo._. 10

5. Average monthly precipitation at Hayden, Colo........ 10

6. Average monthly snowfall at Hayden, Colo._. 11

7. Schematic of lysimeters at reclaimed coal spoil-a. 13

8. Plan view of lysimeters and soil-water access tubes at reclaimed coal spoil-_.

9. Pressure-vacuum soil-water sampler-_ 16

10. Plan view of porous-cup lysimeters and soil-water access tubes at undisturbed site-..

11. Average soil-water content in the top 6 feet of soil for the lysimeter site, the coal-spoil soil-water access-tube site, and the undisturbed site, and monthly total precipitation-..- 
Figures 12-21. Plots showing:

Page

12. Comparison of average maximum and average minimum soil-water content at the undisturbed site for

1979 and 1980-1-0

13. Comparison of average maximum and average minimum soil-water content at the coal-spoil site for 1978, 1979, and 1980-1

14. Increase in soil-water content: Soil depth compared to water content and soil porosity at undisturbed

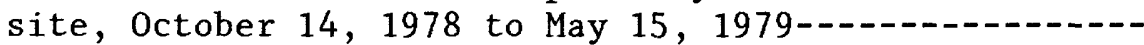

15. Decrease in soil-water content: Soil depth compared to water content and soil porosity at undisturbed site May 15, 1979 to October 15, 1979-_-_-_-

16. Increase in soil-water content: Soil depth compared to water content and soil porosity at coal-spoil soil-water access-tube site, October 14, 1978 to March 29, 1979-water content: Soil depth compare

17. Decrease in soil-water content: Soil depth compar
to water content and soil porosity at coal-spoil soil-water access-tube site, March 29, 1979 to October 15, 1979-_-

18. Increase in soil-water content: Soil depth compared to water content and soil porosity at lysimeter site, October 14, 1978 to March 29, 1979-_-.......-.

19. Decrease in soil-water content: Soil depth compared to water content and soil porosity at lysimeter site, March 29, 1979 to October 15, 1979-_-.-.-.--

20. Cations (calcium + magnesium + sodium + potassium) compared to anions (bicarbonate + sulfate + chloride + fluoride) in water from the lysimeters-.--..--

21. Dissolved-solids concentration in samples of water from the five lysimeters compared to date of

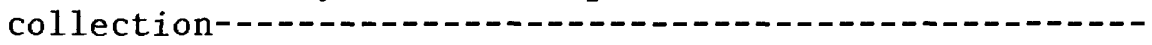

22. Piper-trilinear diagram showing lysimeter data--_-.---.--

23-25. Plots showing:

23. Saturation indices for calcite compared to date samples were collected from the lysimeters--..--

24. Saturation indices for dolomite compared to date samples were collected from the lysimeters-.--.-.---

25. Saturation indices for gypsum compared to date 


\section{TABLES}

Table 1. Minerals or mineral groups detected by X-ray diffraction

Page

in coal-spoil material from locations throughout the

Seneca Mine-1....- 28

2. Coal-spoil annual water balance-1...- 29

3. Lysimeter deep-percolation recharge-1- 30

4-8. Water-quality data from:

4. Lysimeter 1- 51

5. Lysimeter 2-10 59

6. Lysimeter 3-67

7. Lysimeter 4-14

8. Lysimeter 5-10 80

9-13. Water-quality data from Yampa River above Hayden:

9. First application each day-1 87

10. Second application each day-nes 88

11. Third application each day-1... 89

12. Fourth application each day-at 90

13. Fifth application each day-ar.- 91

14-18. Water-quality data from Yampa River water, after transportation to lysimeter site:

14. First application each day-1 92

15. Second application each day-nation 93

16. Third application each day-_as 94

17. Fourth application each day-na-n 95

18. Fifth application each day-ne 96

19-22. Water-quality data from:

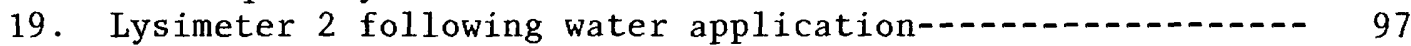

20. Lysimeter 3 following water application--.-.-.-.-.-. 98

21. Lysimeter 4 following water application--.-...- 99

22. Lysimeter 5 following water application---n 100 


\section{CONVERSION FACTORS}

Inch-pound units used in this report may be converted to metric (International System) units by using the following conversion factors:

$\begin{array}{lcl}\text { Multiply inch-pound unit } & B y & \text { To obtain SI unit } \\ \text { atmosphere (atm) } & 6.895 & \text { kilopascal } \\ \text { cubic foot }\left(\mathrm{ft}^{3}\right) & 0.028317 & \text { cubic meter } \\ \text { cubic foot per second }\left(\mathrm{ft}^{3} / \mathrm{s}\right) & 0.028317 & \text { cubic meter per second } \\ \text { foot (ft) } & 0.3048 & \text { meter } \\ \text { gallon (gal) } & 3.785 & \text { liter } \\ \text { gallon per minute (gal/min) } & 0.0630 & \text { liter per second } \\ \text { inch (in.) } & 25.40 & \text { millimeter } \\ \text { inch per year (in/yr) } & 25.40 & \text { millimeters per year } \\ \text { mile (mi) } & 1.609 & \text { kilometer } \\ \left.\text { square foot (ft }{ }^{2}\right) & 0.0929 & \text { square meter } \\ \text { square mile (mi } & & \text { square kilometer } \\ \text { British thermal unit (BTU) } & 2.590 & \text { joule }\end{array}$

Temperature in degree Celsius $\left({ }^{\circ} \mathrm{C}\right)$ may be converted to degree Fahrenheit $\left({ }^{\circ} \mathrm{F}\right)$ by using the following equation:

$$
{ }^{\circ} \mathrm{F}=9 / 5{ }^{\circ} \mathrm{C}+32 \text {. }
$$

Temperature in degree Fahrenheit $\left({ }^{\circ} \mathrm{F}\right)$ may be converted to degree Celsius $\left({ }^{\circ} \mathrm{C}\right)$ by using the following equation:

$$
{ }^{\circ} \mathrm{C}=\left({ }^{\circ} \mathrm{F}-32\right) \times 5 / 9 \text {. }
$$

The following terms and abbreviations also are used in this report:

$$
\begin{aligned}
& \text { milligram per liter }(\mathrm{mg} / \mathrm{L}) \\
& \text { microgram per liter }(\mu \mathrm{g} / \mathrm{L})
\end{aligned}
$$

microsiemens per centimeter at $25^{\circ}$ Celsius $(\mu \mathrm{S} / \mathrm{cm})$

Sea level: In this report "sea level" refers to the National Geodetic Vertical Datum of 1929 (NGVD of 1929)--a geodetic datum derived from a general adjustment of the first-order level nets of both the United States and Canada, formerly called "Mean Sea Level of 1929." 


\title{
SOIL-WATER HYDROLOGY AND GEOCHEMISTRY OF A COAL SPOIL AT A RECLAIMED SURFACE \\ MINE IN ROUTT COUNTY, COLORADO
}

By Robert S. Williams, Jr., and Stephen E. Hammond

\begin{abstract}
Coal-spoil water quantity and quality were monitored, by five drainagetype lysimeters installed in a reclaimed coal spoil. Soil-water access tubes were used to monitor soil-water content at the coal spoil and at an adjacent undisturbed area.

Results of the monitoring indicate that the undisturbed soils are nearly saturated at 4.5 to 5 feet. Coal spoils are not near saturation at similar depths. Normal recharge in the nearby unmined area is estimated to be about 0.5 inch per year. At a depth of 8 feet, 2 to 6 inches of water per unit surface area is percolating through the coal spoil in the lysimeters. The water is potential recharge to a coal-spoil aquifer.

The coal-spoil leachate has an average dissolved-solids concentration of 3,600 milligrams per liter. Calcium (460 milligrams per liter), magnesium (370 milligrams per liter), and sulfate (2,540 milligrams per liter) are the dominant ions in the leachate; sodium (111 milligrams per liter) and bicarbonate (224 milligrams per liter) are present in lesser concentrations. Gypsum dissolution and carbonate dissolution by carbonic acid from carbon dioxide and by sulfuric acid from pyrite oxidation account for most of the dissolvedsolids concentration. Saturation indices indicate that the water is saturated with many minerals and is composed of the aforementioned ions.
\end{abstract}

\section{INTRODUCTION}

Increasing energy demands throughout the United States have resulted in a renewed interest in using coal as a source of energy. In northwestern Colorado, as in other parts of the United States, surface mining is an economical way of mining the coal reserves.

During surface mining the overburden is broken up and removed from above the coal seams; this destroys the natural layering found in sedimentary deposits. The overburden material is placed in coal-spoil piles that are eventually recontoured to approximate the original land surface. 
During spoil-pile placement and after the coal spoil is reclaimed, water from precipitation can enter the coal spoil. The ease of water movement, the quantity of water moving, and the quality of the water in a coal spoil may be different from a similar undisturbed area. The quantity and quality of water in the semiarid West is a prime concern to water users. Water from precipitation may percolate to ground water more easily or less easily through a coal spoil than through an undisturbed area. If water infiltrates into the coal spoil more easily than through the undisturbed area, then more water may be available for ground-water recharge; thus the volume of water in ground-water storage can increase. Evapotranspiration also can limit the quantity of ground-water recharge by removing the water from the subsurface. If the ground-water recharges a stream, then base flow can increase. However, if the coal-spoil recharge is less than the undisturbed area recharge, then the reverse of the condition mentioned before may exist, and ground-water and surface-water sources may decrease in areas of coal surface mining.

The quality of water that moves through a coal spoil is as important as the quantity. The water flowing through the coal spoil generally will have increased concentrations of dissolved solids. This increase in dissolvedsolids concentrations can be detrimental, if the spoil water is a source of surface or ground water. For instance, crop production may be decreased or even unfeasible as a result of increased dissolved-solids concentrations. Use of the water by downstream municipalities also may be affected, because of the extra water purification required to make the water potable. Domestic use of ground water also may be limited by increased concentration of dissolved solids.

Some of the surface coal mines in northwestern Colorado are found throughout much of the area of recharge in their respective drainage basins. As a result, the mine may have a considerable effect on the hydrology of that basin. The water flowing from the basin then can affect adjacent larger basins. In locations where a number of separate surface coal mines affect small separate drainage basins, the cumulative effect on a larger drainage basin may be substantial. Therefore, surface coal mining has the potential to alter the natural hydrologic system. The alteration may result from changes in both the quantity of water and the quality of water.

In 1977, the U.S. Geological Survey, in cooperation with the U.S. Bureau of Land Management, began a study to determine and compare the quantity and quality of water in a coal spoil and in an adjacent undisturbed site in northwestern Colorado. The objectives were to define water movement, water chemistry, and chemical processes in the unsaturated part of the coal spoil and in the undisturbed area. 


\section{Purpose and Scope}

This report describes:

1. Water movement through the unsaturated top $6 \mathrm{ft}$ of a reclaimed coal spoil. The water percolating through the reclaimed coal spoil can evaporate, can be used for plant respiration and growth, or can percolate to the ground-water system. Soil-water movement also was monitored at a nearby undisturbed site. The undisturbed site was used to compare natural conditions with reclaimed coal-spoil disturbed conditions; and

2. Water chemistry and chemical processes in the unsaturated top $6 \mathrm{ft}$ of a reclaimed coal spoil. The reclaimed coal spoil in this study is an area of recharge for the drainage basin. The relatively unpolluted precipitation that enters and flows through the reclaimed coal spoil may undergo a very different chemical evolution than precipitation that enters and flows through an undisturbed soil. The difference may determine if the reclaimed coal-spoil water continues to be suitable for its previous use or for any intended use.

The approach to monitoring the quantity and quality of water moving through the coal spoil and the unditurbed area was to use lysimeters and soilwater access tubes. The lysimeters at the coal spoil were used to collect water for measuring water quantity flowing out of the lysimeters and also to obtain water samples for chemical analysis. The soil-water access tubes were used to measure soil-water content, so that comparisons could be made between soil-water content in the coal spoil and a nearby undisturbed soil.

The report evaluates water-quantity and water-quality data collected at a coal spoil at the Seneca Mine, operated by Peabody Coal Company ${ }^{1}$, in Routt County, Colo. Data collection began in 1978 and continued through 1980 .

\section{Acknowledgments}

This study was funded in cooperation with the U.S. Bureau of Land Management. The study was done at the Seneca Mine, and the authors would like to thank the mine operators and employees of Peabody Coal Company for the use of their property and their cooperation throughout the study.

\section{PREVIOUS WORK}

The geology of northwestern Colorado has been described by many authors: Berman and others, 1980; Campbe11, 1923; Pear1, 1974; Gaffke, 1979; Miller, 1975; Parsons and Lidde11, 1903; Ryer, 1977. Maps of the area also are available (Dames and Moore, 1980a, 1980b; Tweto, 1976). The American Geological Institute (1976) published a bibliography and index of Colorado geology.

${ }^{1}$ The use of trade, product, industry, or firm names in this report is for identification or location purposes only and does not constitute endorsement of products by the U.S. Geological Survey nor impute responsibility for any present or potential effects on the natural resources. 
Both surface-water and ground-water chemical properties have been studied in northwestern Colorado. Basic data are available for water quality of surface water and ground water in northwestern Colorado (Giles and Brogden, 1978; Gaydos, 1980). Brogden and Giles (1977) discussed the availability of ground water, the quality of ground water, and ground-water circulation near the study area. Chemical and bacteriological data were collected by Covay and Tobin (1981) to describe the quality of water from selected geologic units in Routt County, Colo. Boettcher (1972) reported on the occurrence of ground water in the area.

The U.S. Geological Survey studied the effect of coal mining on regional water resources (Steele and others, 1979; Steele and Hillier, 1981). The Yampa River is the major river draining near the Seneca Mine. Changes in surface-water quantity and quality at the Seneca Mine and adjacent mines may affect the Yampa River. A general survey of the water quality of the Yampa River was conducted during 1972 by the Colorado Department of Health (Misbach, 1972). At that time it was determined that, "The Yampa River is meeting water-quality standards for the State of Colorado with the exception of $\mathrm{pH}$ violations exceeding the 8.5 maximum allowable limit in 17 of 28 river sampling points." Wentz and Steele (1980) analyzed the stream quality of the Yampa River and found a 14-percent increase in specific conductance since 1951. They attributed the change to increased agricultural and municipal use of water. Small streams near the study area were found to be saturated with respect to common carbonate minerals (calcium, magnesium, iron, manganese, and lead) (Turk and Parker, 1982).

Revegetating disturbed lands has been a prime concern in mine-land reclamation. "Reclamation of drastically disturbed lands" (Schaller and Sutton, 1978) encompasses a wide range of topics on reclamation. Techniques for vegetation analysis and measurement at mine sites are given by Cook and Bonham (1977). Revegetation and stabilization guidelines for mine sites are reported by Cook and others (1974). A series of workshop proceedings was published through Colorado State University (Berg and others, 1974; Zuck and Brown, 1976; Kenny, 1978; Jackson and Schuster, 1980). The topic of the workshops was revegetation of high-altitude disturbed lands, which includes reclamation of mined land as well as other disturbed lands.

The Piceance basin is about $70 \mathrm{mi}$ southwest of Hayden, Colo. (fig. 1). The topography, vegetation, and precipitation are similar in the Piceance basin and in the study area for this report. Therefore, some of the results of work done in the Piceance basin will be used in this report to estimate conditions in the study area. Ficke and others (1974) and Weeks and Welder (1974) published basic data on the hydrology of the Piceance basin. A water balance for the Piceance basin was estimated by Wymore (1974). Weeks and others (1974) used a digital watershed model and a digital ground-water model to simulate the effects of oil-shale development on the hydrology of the Piceance basin. A digital model was used to simulate ground-water flow in the Piceance basin (Weeks, 1978). A detailed description of the model is in the report. A mathematical model was used to simulate the ground-water-quality changes that would occur as a result of mine activities in the Piceance basin (Robson and Saulnier, 1981). 
Mine drainage can contaminate natural water resources, both during and after mining. A reconnaissance study of the effect of mine drainage on water quality in Colorado was designed to identify areas of surface-water degradation (Wentz, 1974). Subsequent to the study, 17 areas within Colorado were chosen for additional study (Moran and Wentz, 1974). The study concluded that significant quantities of trace elements are added to streams from metal-mine drainage, but that, with enough time and downstream distance, the streams can recover naturally. Turk (1982) investigated the thermodynamic controls on water quality from underground coal mines in Colorado. Turk determined that the water quality had developed by interaction of calcite-saturated ground water with sodium-rich marine shales.

The effects of soil-surface manipulation on water pollution at semiarid mined lands were investigated by Dollhopf and others (1977). The authors, in their interim report, stated that watersheds that contain topsoil produce less runoff than watersheds without topsoil. The authors also stated that unsaturated soil-water flow is an important component of the coal-spoil hydrologic cycle and actually may control the long-term success of vegetation reclamation procedures.

Hounslow and others (1978) used factor analysis to establish relations among rock and water variables. The predictive method was designed to be an efficient and economical means of predicting potential changes in ground-water quality that result from surface mining of coal.

McWhorter and others (1977) studied various aspects of coal spoil. Some of their conclusions follow and are of interest for this report. The coal spoil has no layers; thus, water percolates vertically through the coal spoil, until it reaches a water table or rock stratum. The deep percolation enables considerable dissolution of soluble minerals, and there is a resulting large dissolved-solids concentration in the ground water. The ions most commonly found are calcium, magnesium, sodium, bicarbonate, and sulfate. The large concentrations are not expected to decrease for many decades.

\section{DESCRIPTION OF STUDY AREA}

The coal-spoil study area is $6 \mathrm{mi}$ southeast of Hayden, Colo., in secs. 34 and 35 of T. 6 N., R. 87 W., within the Grassy Creek drainage (fig. 1). Grassy Creek, the main drainage, flows to the north. The study area is at the Seneca Mine, which is operated by the Peabody Coal Company. Because coal mining began during 1968, a large part of the study area previously has been strip mined and subsequently reclaimed. The original southwesterly aspect still remains; however, the altitude and the surface contours have changed a little, and components of the hydrologic cycle associated with the coal spoil have changed. The part of the watershed surrounding the study area ranges in altitude from 6,600 to $7,300 \mathrm{ft}$ and is approximately $7.5 \mathrm{mi}^{2}$ in area. Vegetation at the site consists primarily of grasses, sage, and oakbrush. 

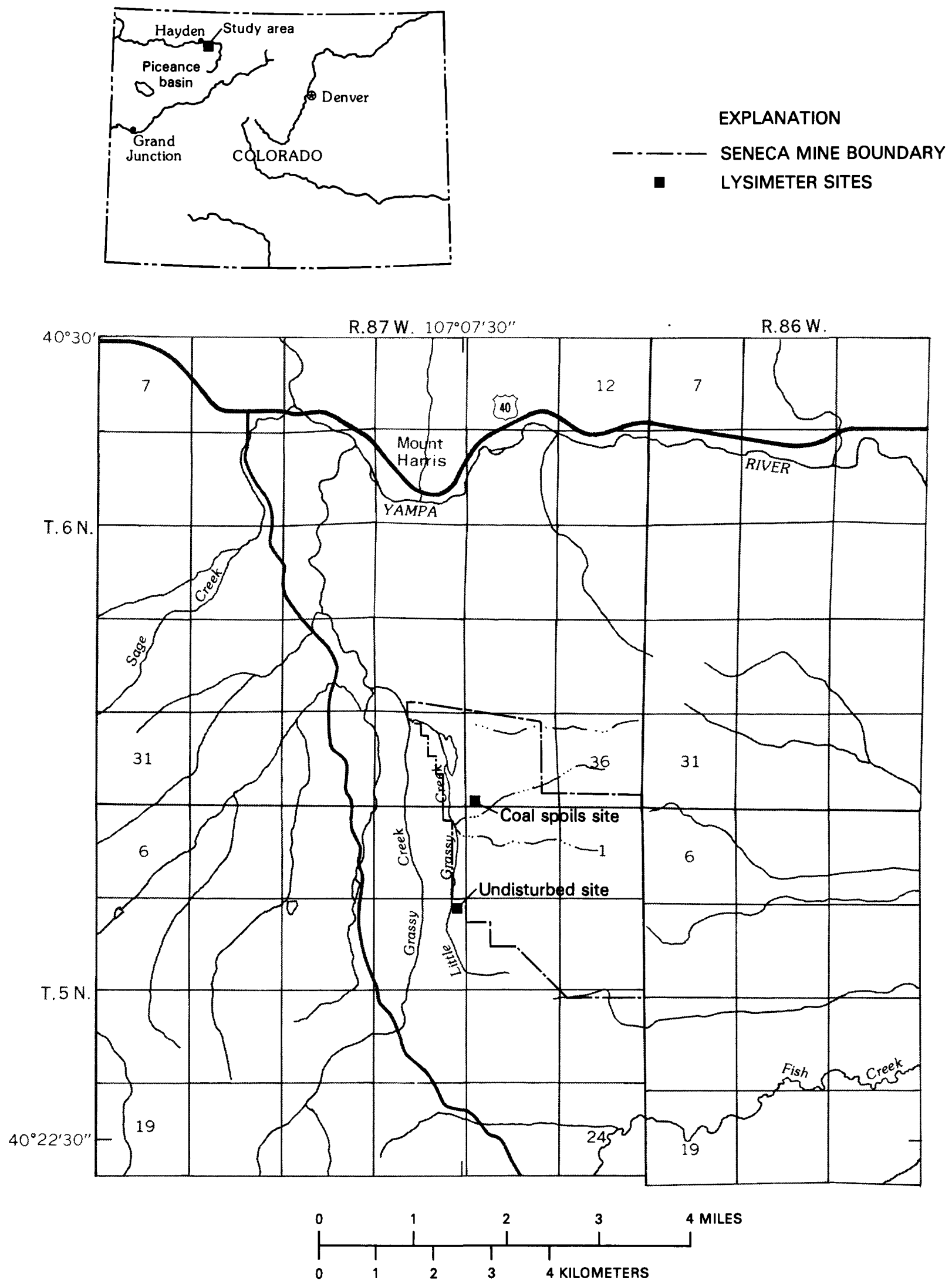

Figure 1.--Location of study area and the Piceance basin. 
The premining surficial geology of the Seneca Mine and surrounding area is shown in figure 2. Even though numerous folds are found throughout northwestern Colorado, one of the largest of these is the Tow Creek anticline, which forms the ridge of the area being mined. Faults also are present throughout the area; however, their effect on local flow patterns at the mine site is unknown.

Upper Cretaceous rocks are present near the mine site (fig. 3) (Bass and others, 1955). The oldest formation cropping out in the area is the Mancos Shale, a dark-gray shale about 4,600 ft thick. The Williams Fork and the Iles Formations are part of the Mesaverde Group (about 3,000 ft thick) that overlies the Mancos Shale. Sandstone, sandy shale, shale, and coal can be found throughout the Mesaverde Group. Two major sandstone members are present: the Trout Creek Sandstone in the Iles Formation and the Twentymine Sandstone Member in the Williams Fork Formation. The Williams Fork Formation contains the Middle coal group, which is the coal being mined at the Seneca Mine. The coal beds dip to the west at about 8 degrees and are overlain by about 50 to $75 \mathrm{ft}$ of shale. The subituminous coals (12,000 BTU's) being mined are the Lennox and the Wadge; the Wadge is deeper and more economically important. The sulfur content of the Wadge coal is about 0.5 percent; the sulfur content of the Lennox coal is about 1.7 percent. The Wadge coal generally is blended with the Lennox coal before combustion at the power plant to decrease the sulfur content. The Lennox coal seam is $4 \mathrm{ft}$ or less thick, and the Wadge coal seam is as much as $10 \mathrm{ft}$ thick. About $50 \mathrm{ft}$ of sandstone and shaley sandstone separate the two coal seams.

The Lewis Shale is a dark-gray shale, about 1,700 ft thick, that overlies the Mesaverde Group and underlies the Lance Formation. The Lance Formation is about 1,400 ft thick and consists of sandstone, shale, and some coal.

The study site is in a semiarid region. Average monthly maximum temperatures reach almost $90^{\circ} \mathrm{F}$ in the summer; average monthly minimum temperatures are about $0^{\circ} \mathrm{F}$ in the winter (ENMAP Corp., 1981) (fig. 4). Average annual temperature is approximately $42^{\circ} \mathrm{F}$.

Precipitation in the area is approximately $16 \mathrm{in} / \mathrm{yr}$ and is fairly evenly distributed throughout the year (National Oceanic and Atmospheric Administration, 1982) (fig. 5). The precipitation is evenly distributed because the local altitude change is not significant enough to cause sufficient cooling of the moist Pacific air moving through the area in the winter to cause excess winter precipitation. Precipitation does increase during the winter to the east near Steamboat Springs, Colo., because of cooling of moist air, as the air mass rises and flows over the mountains. Total annual snowfall at Hayden, Colo., is 106 in.; 65 percent of the snow falls during December, January, and February (ENMAP Corp., 1981) (fig. 6). Snow accumulation is the primary source of streamflow in the area; summer precipitation contributes little to overall water availability. 


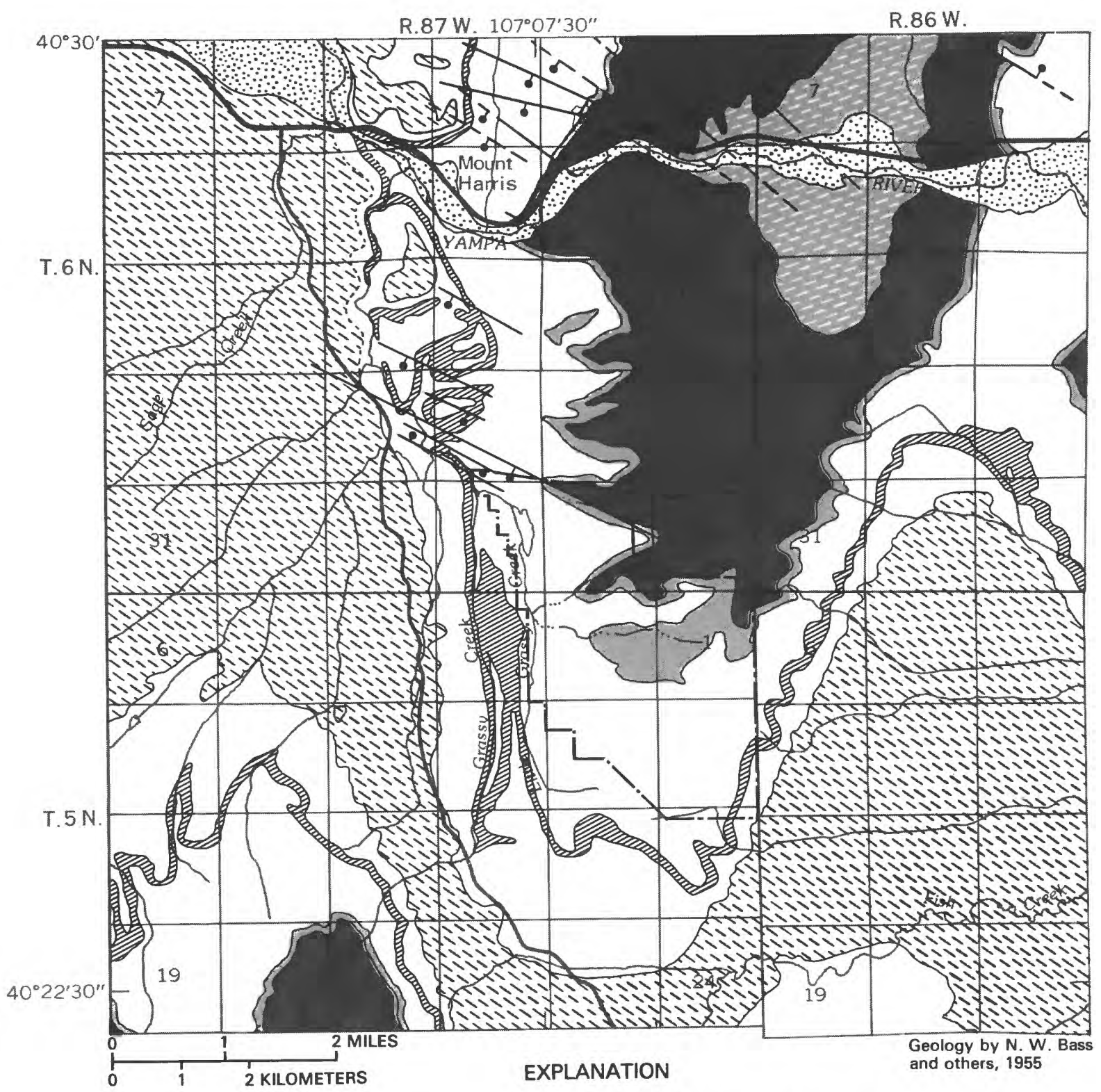

ALLUVIUM

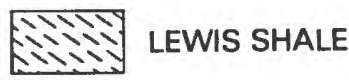

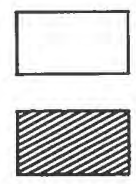

WILLIAMS FORK FORMATION

Twentymile Sandstone Member

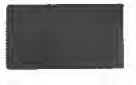

ILES FORMATION

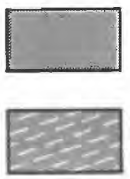

Trout Creek Sandstone Member

MANCOS SHALE

CONTACT--Dashed where approximately located

FAULT --Bar and ball on downthrown side SENECA MINE BOUNDARY

Figure 2.--Geology near the Seneca Mine. 


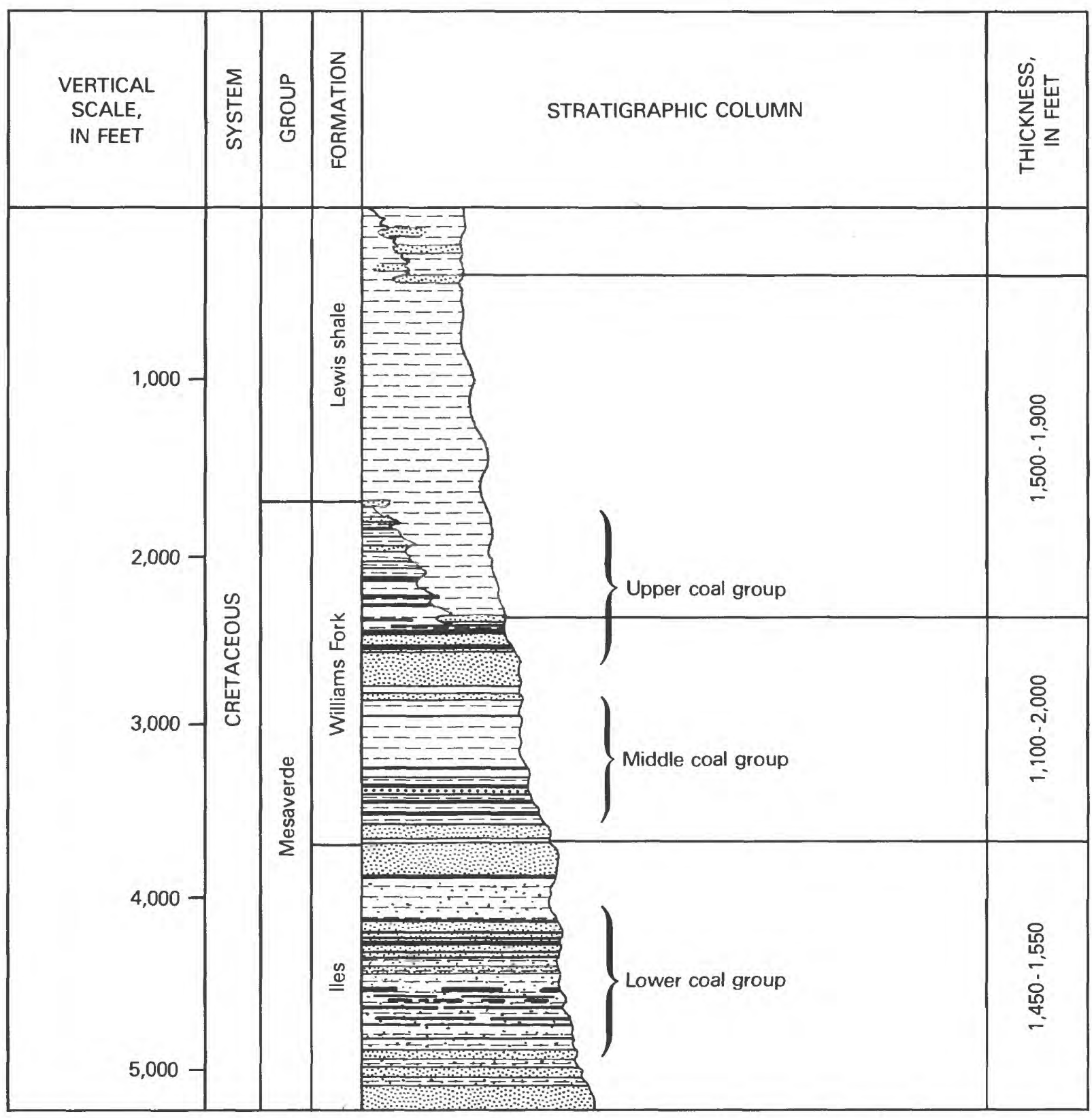

EXPLANATION

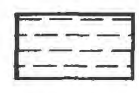

SHALE

SANDSTONE

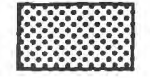

GRAVEL

SANDY SHALE

COAL

Figure 3.--Generalized columnar section of exposed rocks in parts of Routt and Moffat Counties (from Bass and others, 1955). 


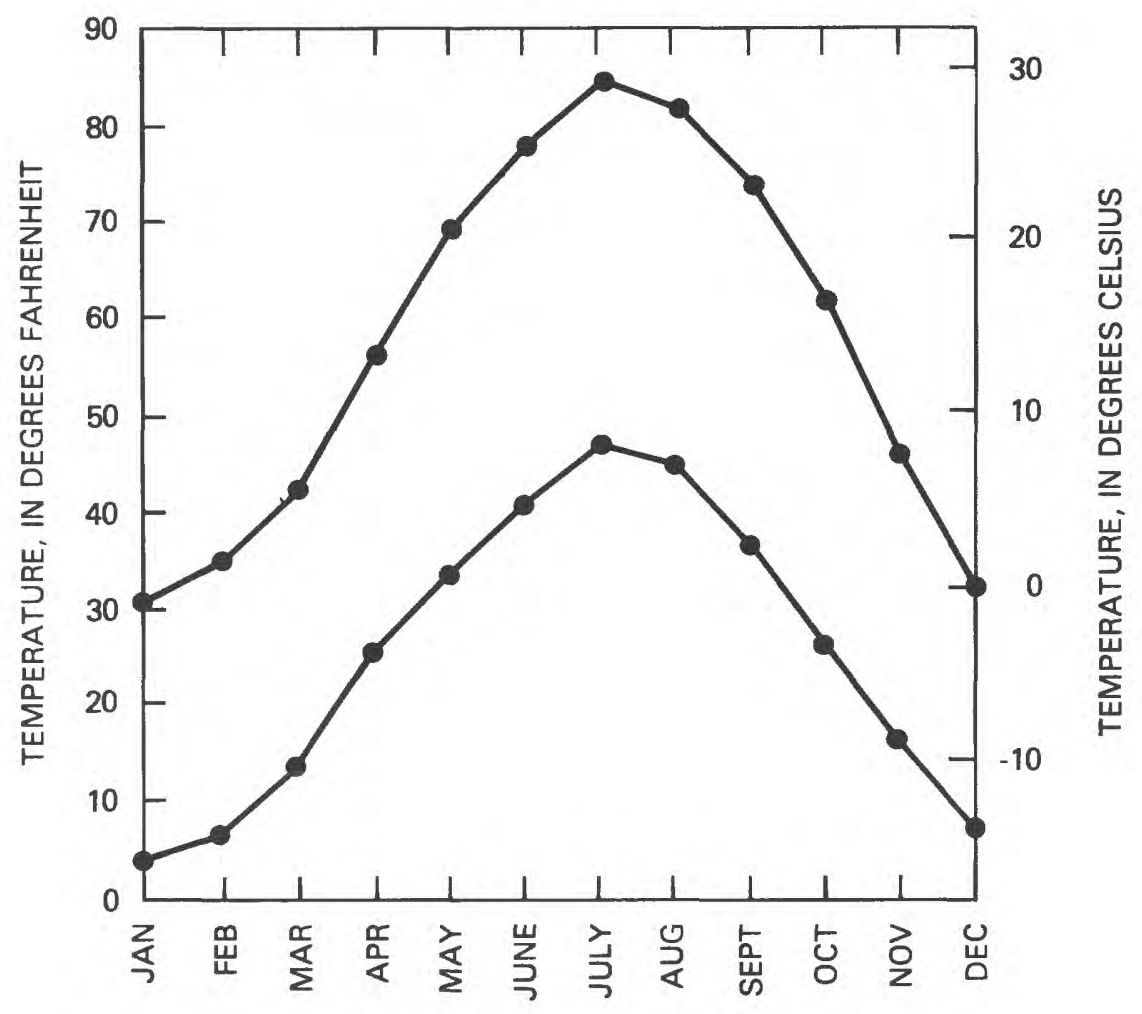

Figure 4.--Average monthly maximum and average monthly minimum temperatures at Hayden, Colo.

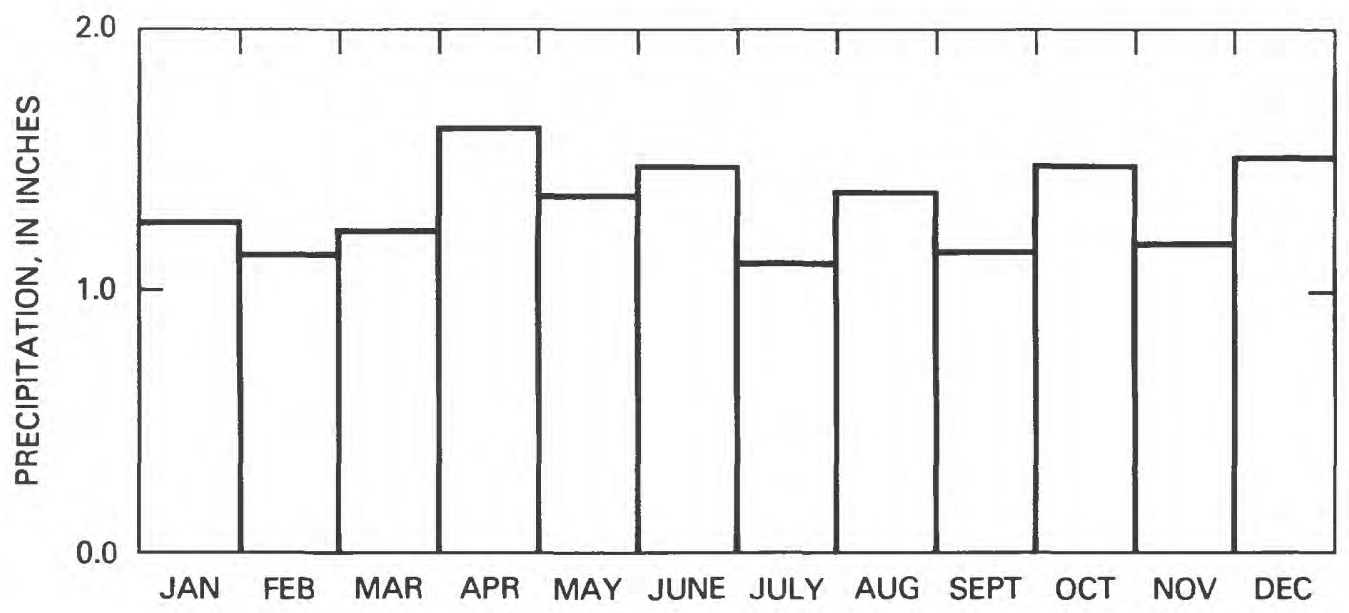

Figure 5.--Average monthly precipitation at Hayden, Colo. 


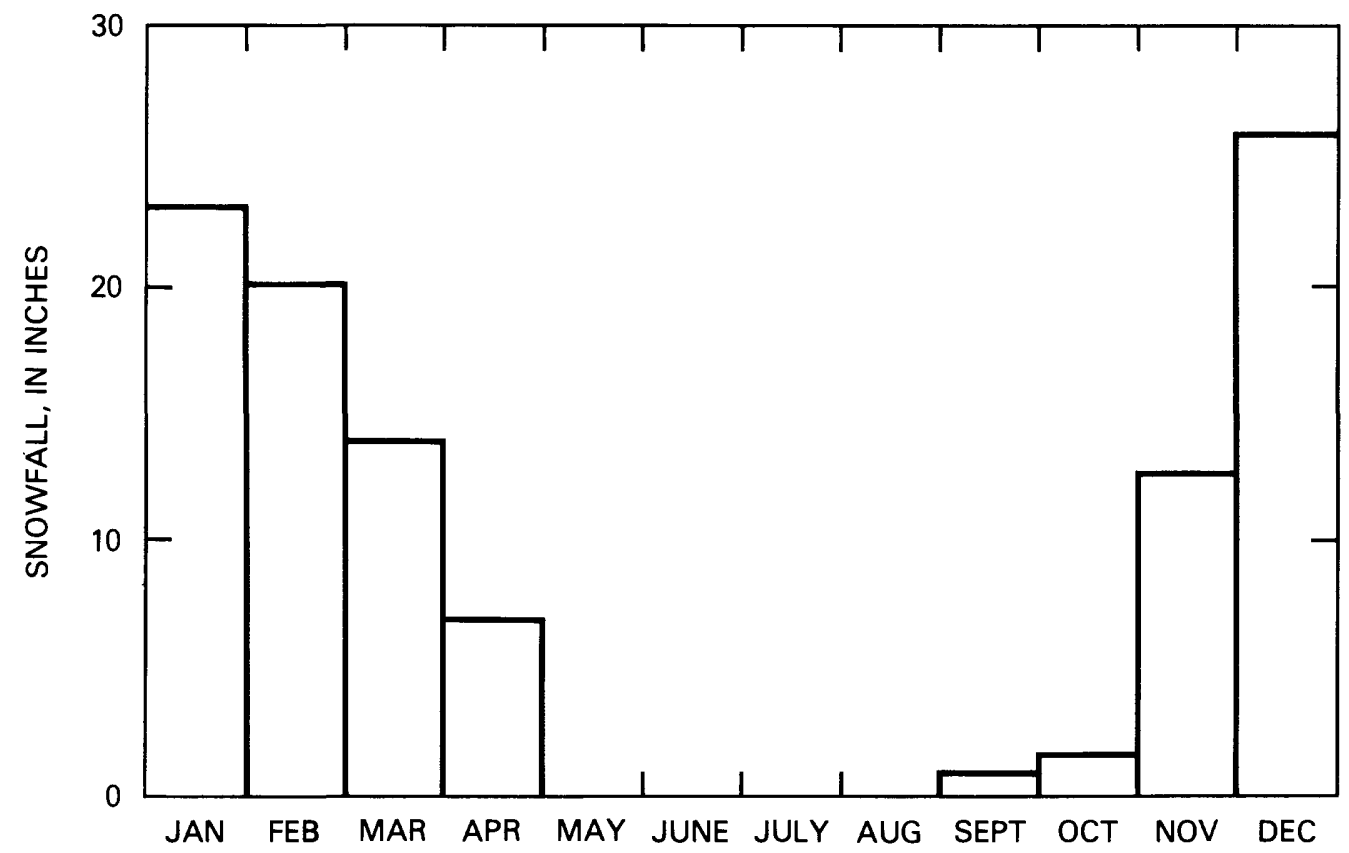

Figure 6.--Average monthly snowfall at Hayden, Colo.

Surface-water resources have been developed far more than the groundwater resources throughout the region. Surface-water flow rises rapidly in April, remains high in May, and recedes in June. The majority of streamflow occurs during these 3 months. This pattern of flow results primarily from snowmelt during the spring. Surface-water flow throughout the remainder of the year is sustained largely by ground-water discharge to the stream (Iorns and others, 1965). Streams near the study area are ephemeral or have discharges less than $0.1 \mathrm{ft}^{3} / \mathrm{s}$ for much of the year.

Ground water is used primarily for domestic and stock-watering purposes. Recharge occurs from stream loss and precipitation. The recharge quantity is not known; however, evapotranspiration, confining beds, and aquifers with small yields (less than $25 \mathrm{gal} / \mathrm{min}$ ) probably limit the recharge. Ground-water quality varies in the area. Calcium, magnesium, and sodium are the dominant cations; bicarbonate and sulfate are the dominant anions.

\section{DESCRIPTION OF INSTRUMENTATION}

Three sites are discussed in this section: (1) The lysimeter site, which includes five drainage-type lysimeters, each containing a soil-water access tube; (2) the coal-spoil soil-water access-tube site, which includes the area outside the lysimeters; and (3) the undisturbed site, which includes 24 porous-cup lysimeters and 8 soil-water access tubes. Both the lysimeter site and the coal-spoil soil-water access-tube site are on reclaimed coal spoil; together, these sites will be referred to as the coal-spoil site. The undisturbed site is a site that has not been disturbed by surface mining. 


\section{Lysimeters}

Tank or drainage-type lysimeters can be used to collect water that percolates through the material contained in the lysimeter. This water then can be analyzed to determine its chemical composition. The quantity and the timing of the water movement also can be recorded. The lysimeters used in this study collected water from the top $7 \mathrm{ft}$ of a reclaimed and recontoured coal spoil. This top $7 \mathrm{ft}$ is a dynamic zone, where evapotranspiration and aqueous chemical reactions occur.

Five tank or drainage-type lysimeters were installed in a reclaimed coal spoil at an altitude of approximately 7,000 ft. The lysimeter site has a southwesterly aspect and is on a fairly flat slope. A site where coal-spoil material had just been replaced and recontoured was chosen for the lysimeters.

Coal-spoil material excavated for the lysimeters was replaced in the lysimeters. The lysimeters were built so that their tops would be at ground level, which enables natural precipitation to recharge the lysimeters. This location also enables other abiotic and biotic factors such as temperature and vegetation to affect the spoil material, both inside and outside the lysimeters, in the same manner.

The lysimeters are 8-ft wide by $10-\mathrm{ft}$ long by 8 -ft deep (fig. 7). The walls are poured concrete, 8-in. thick. The outside of the walls is tarred to prevent acid decomposition of the concrete. The floor of the lysimeter is 10 in. of sulfate-resistant concrete that slopes to facilitate water movement out of the lysimeter. Footings $3-\mathrm{ft}$ wide by $2-\mathrm{ft}$ deep were placed under all walls.

After sandblasting, the inside walls of each lysimeter were painted with an epoxy paint that has excellent chemical, moisture, and abrasion resistance. The paint was chosen because it would be inert when it was in contact with the spoil material. As an added precaution, plastic sheeting reinforced with fiberglass was used to line the inside of the lysimeters before spoils were placed in the lysimeters.

Three 7-ft sections of slotted PVC pipe were placed in the bottom of each lysimeter to facilitate flow to the drain. Gravel was placed to a depth of 9 to $12 \mathrm{in.}$ around and over the PVC pipe. A 7-ft, aluminum, soil-water access tube was placed at the center of each lysimeter before the spoil material was placed in the lysimeter.

A backhoe was used to place the spoil material in the lysimeters. Every attempt was made to replace the spoil material in the lysimeters so that the material within the lysimeters would be similar to the material outside. Rock fragments greater than 18 in. in diameter were not placed in the lysimeters. 


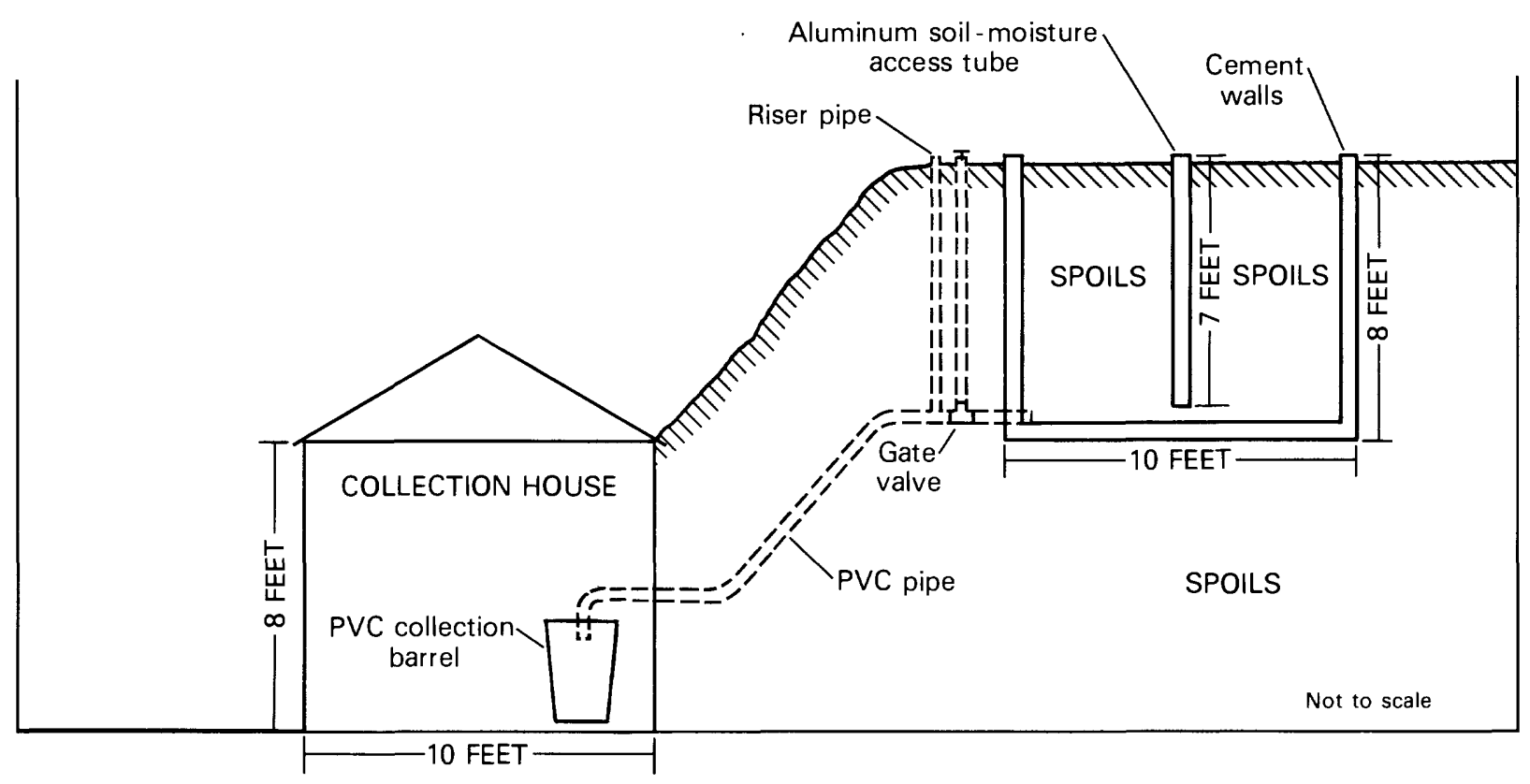

Figure 7.--Schematic of lysimeters at reclaimed coal spoil.

A 4-in. piece of PVC pipe was placed at the base and in the center of the west wall of each lysimeter; the lysimeter drains through the PVC pipe at this point. One ft from the wall, the PVC pipe enters a gate valve that is operated from land surface. One $\mathrm{ft}$ beyond the gate valve is a tee coupling that is connected to the surface by a 2-in. PVC pipe. The gate valve and 2-in. pipe were installed to enable cleaning of the pipe leading to the collection house. If water unexpectedly ceased flowing from a lysimeter, the gate valve could be closed, and water could be poured through the 2-in. riser pipe. By this approach, it could be determined if the problem is in the PVC leading to the collection house, or in the lysimeter itself.

Two-inch PVC pipe on a 4-percent slope connects each lysimeter independently to a series of separate PVC collection barrels in a collection house downslope. From these barrels, water samples were obtained for chemical analysis. The timing and quantity of water moving through the lysimeters was determined by continuously monitoring water levels with recorders in the PVC collection barrels. 
Two sets of paired lysimeters and one single lysimeter were connected to the collection house (fig. 8). Lysimeter 1 contained the coarsest material, and the end pair of lysimeters ( 4 and 5 ) contained the least coarse material. The middle lysimeters, 2 and 3 , were filled with material intermediate in texture. Lysimeters 2 and 4 were covered with about 12 in. of topsoil. The other three lysimeters $(1,3$, and 5$)$ had only raw spoil material at the surface. The topsoil was added to determine the difference in hydrologic response between spoil material covered with topsoil and raw spoil material. The lysimeters were seeded at the same time and in the same manner as the rest of the reclaimed coal spoil.

As stated earlier in this section of the report, the lysimeters were filled with the coal spoil excavated from the lysimeter site. The variation in texture coarseness was a result of the way the coal spoil was replaced and not the result of the experimental design of the study.

Approximately $2 \mathrm{mi}$ south of the lysimeters is an undisturbed site. At this location, 24 porous-cup lysimeters and a shelter for collecting samples were installed. The following information, from a Soilmoisture Equipment Corp. brochure (1976), describes the porous cup lysimeters (also see fig. 9).

"Pressure-vacuum soil-water samplers, Model 1920, are constructed of 1.9 inches diameter PVC tube with a porous ceramic cup bonded to one end. They are approximately 24 inches in overall length and are provided with two small diameter access tubes for evaluating the samples and removing the collected sample. A screw thread clamping ring, at the end of the sampler, seals the access tubes into the sampler by means of a large diameter neoprene plug. After the sample has been collected, it is forced out of the sampler by putting pressure on one end of the access tube to force the sample out of the other end of the access tube. The samplers are designed for installation up to 50 feet in depth."

The porous cups were placed at a depth of $5 \mathrm{ft}$ because this depth was believed to be below the zone of dynamic soil-water change. Therefore, only water that was potentially percolating deeper to the ground water would be sampled, rather than water that was subject to evapotranspiration loss. Unfortunately, this zone proved to have very little available water that could be drawn into the porous cup. As a result, the porous-cup lysimeters did not yield sufficient water for chemical analysis. 


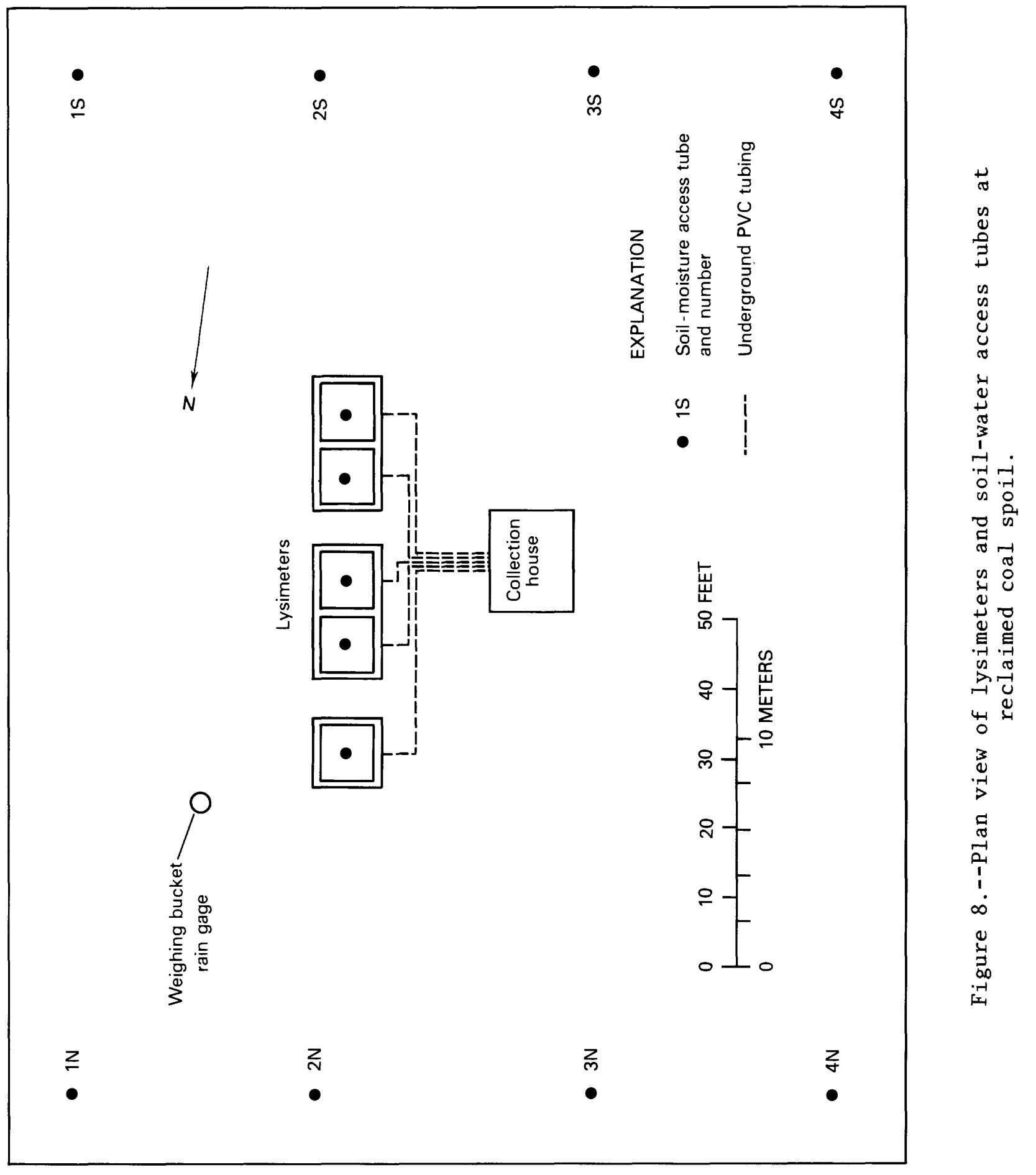




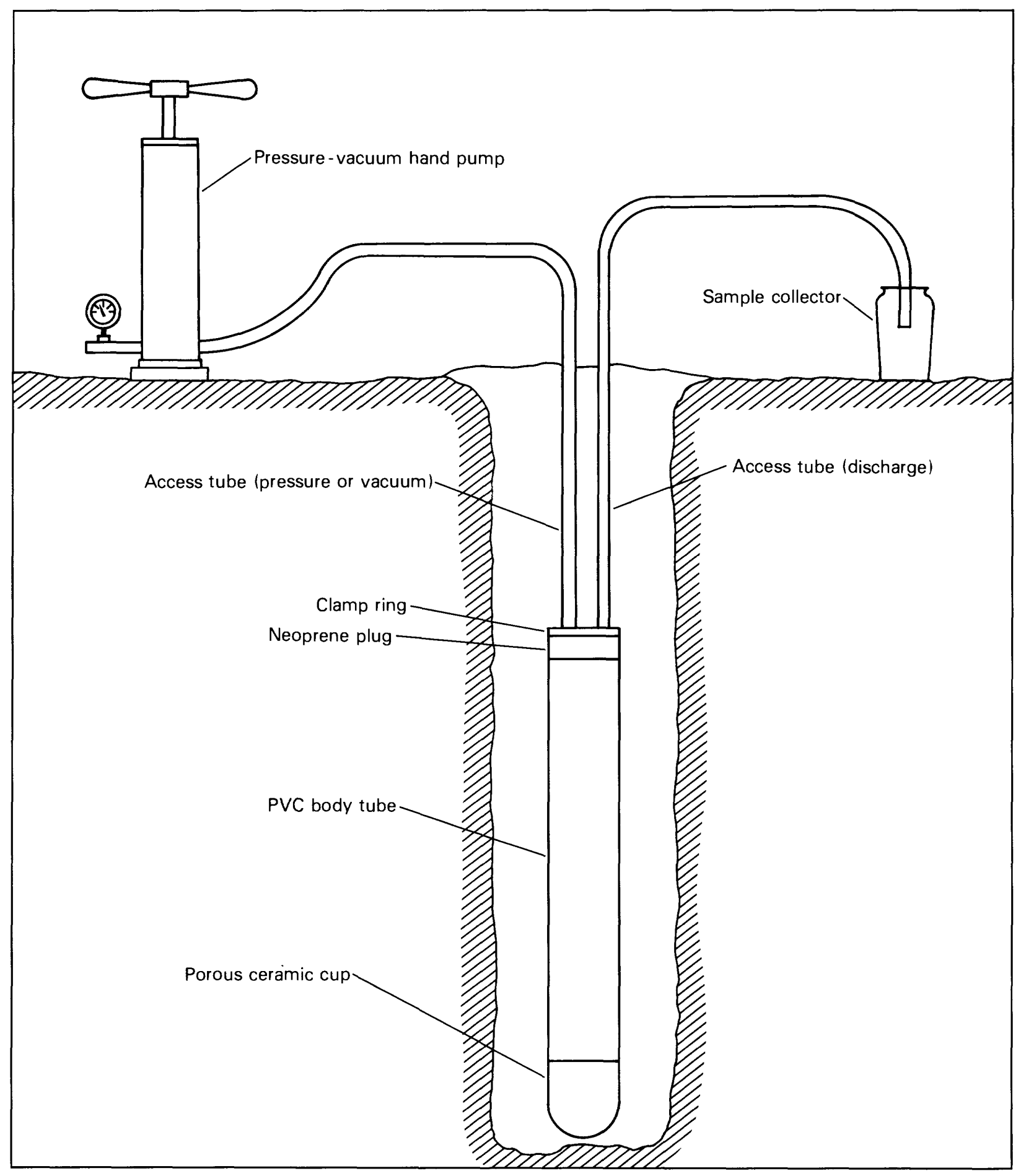

Figure 9.--Pressure-vacuum soil-water sampler. 


\section{Soil-Water Access Tubes}

Soil-water access tubes were installed at three sites at the mine. Five drainage-type lysimeters were installed at the lysimeter site, each of which has a 7-ft-deep access tube at its center (fig. 8). Eight access tubes were installed at the coal-spoil soil-water access-tube site. These tubes were installed at depths ranging from 4.5 to $7 \mathrm{ft}$ because it was difficult to drill through the spoil material. An additional eight access tubes were installed at the undisturbed site (fig. 10). Seven of the tubes were $7 \mathrm{ft}$ deep, and one was $6.5 \mathrm{ft}$ deep. More data were available at $6 \mathrm{ft}$ than $7 \mathrm{ft}$, and the $6 \mathrm{ft}$ depth is below the zone of dynamic soil-water change; therefore, $6 \mathrm{ft}$ was the depth used for soil-water content calculations.

The soil-water access tubes were made of 2-in-diameter aluminum, through which a neutron probe was lowered to measure soil-water content. The theory of neutron moderation has been discussed by many authors (Gardner and Kirkham, 1952; Merriam, 1960; Buckman and Brady, 1969). The radius of influence of the neutron probe depends on the per-unit-volume wetness of the soil and the strength of the source (Van Bavel and others, 1956). Hydrocarbons (organic matter, coal) can introduce error if they are present in sufficient quantity. Although fragments of coal can be found in the coal spoil, and organic matter would be present in the undisturbed soil, they were assumed to introduce minimal error. Soil porosity was measured by lowering a density probe into the soil-water access tubes.

The density probe measures the subsurface wet density by using backscatter and absorption of nuclear radiation. The radius of influence for detection by the probe is about 5 in. The probe operates by emitting gamma radiation at a constant average rate. The degree of scattering is proportionate to the density of the surrounding medium. The degree of backscatter then is measured by a detector and recorded on a digital readout for user recording and later analysis.

\section{Neutron-Probe Calibration}

Gravimetric methods were used to determine the quantity of soil water in soil-core samples. Immediately after coring, an aluminum access tube was placed in the core hole. A neutron probe was positioned at points in the hole where each core was taken. Counts then were recorded. These counts were used later with the gravimetric water-content determinations to develop a calibration curve using linear-regression analysis. The coefficient of determination $\left(r^{2}\right)$ was 0.89 with 94 samples. The water content ranged from about 5 percent to 35 percent.

\section{Periods and Types of Data Collection}

Soil-water measurements were made at the lysimeter sites during 1978, 1979, and 1980. The soil-water access tubes were installed at the undisturbed site in June 1978, and soil-water measurements were begun in July 1978.

Precipitation was measured using a weighing-bucket rain gage throughout the year and a float-type rain gage during the summer months. Lysimeter discharge was measured periodically for quantity and tested for quality. 


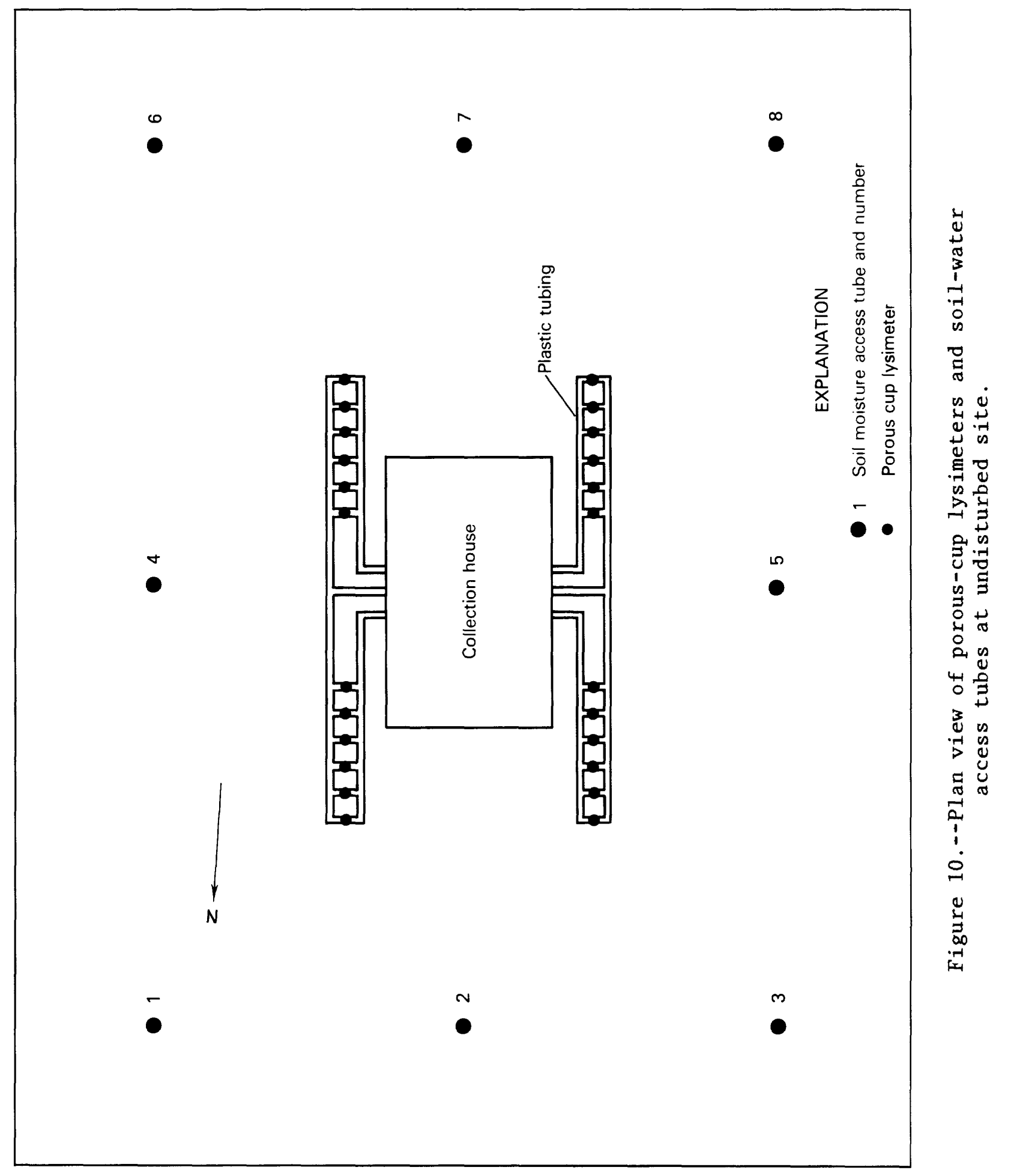


Once precipitation infiltrates into the soil matrix, it becomes soil water and "is subject to large fluctuations of quantity and quality in response to transpiration and evaporation" (Davis and DeWiest, 1966). Soil water in the top 3 to $5 \mathrm{ft}$ of a coal spoil or an undisturbed soil can be lost to evapotranspiration, can be retained in the coal spoil or soil matrix, or can be lost to deep percolation and eventually become part of the ground-water system. (Hereafter, soil water will mean water from coal spoil, or water from the upper 3 to $5 \mathrm{ft}$ of undisturbed soil, unless otherwise specified.)

\section{Comparison of Sites}

Because the lysimeters are isolated structurally from the rest of the coal spoil, it is necessary to compare the lysimeter water content with the surrounding coal-spoil water content to determine if the lysimeters water content is representative of the coal-spoil water content. The coal spoil may have different water-holding characteristics than the undisturbed soil, so the potential for this difference needs to be examined.

The soil-water content, in inches, within a site was fairly consistent among the tubes. The soil-water content for each depth, and the soil-water content through the total depth for each access tube within a site, was always within two standard deviations of the average for the site, assuming a normal distribution.

The average of the total soil-water content through the first $6 \mathrm{ft}$ of depth was used to compare the sites. Soil-water content was summed at each access tube to determine the total soil-water content. The total soil-water contents for each access tube at a site then were added together, and the average soil-water content for the site was determined. These averages are reported as average total-maximum soil-water content and average total-minimum soil-water content. The average soil-water content for the lysimeter site, the coal-spoil soil-water access-tube site, and the undisturbed site are shown in figure 11. Graphically, it can be seen that the coal-spoil soil-water access-tube site generally contains slightly more water than the lysimeter site. The difference is probably the result of compaction differences. The coal-spoil sites do show similar changes in soil-water content with time; both sites will be considered as one population for this report.

The undisturbed site contains more water than the coal-spoil site (fig. 11). The greater water content of the undisturbed site possibly could result from differences in precipitation rather than soil structure and texture. However, because the sites are only a few miles apart and there is little difference in altitude, precipitation at both sites is assumed to be very similar.

Another way to evaluate the differences in water content between sites is to compare the difference between maximum and minimum water content for the sites. This difference shows the volume of water stored and depleted throughout the year. Analysis of variance shows all these differences to be nonsignificant. Therefore, the volume of water between the maximum and minimum 
soil-water content probably is the same at all sites. This means the quantity of water held between the maximum and minimum soil-water content for each year is about the same for both the reclaimed coal-spoil site and the undisturbed site. However, the rate at which water flows through these systems, and the quantity of water present at different depths at certain times during the year, may be quite different.
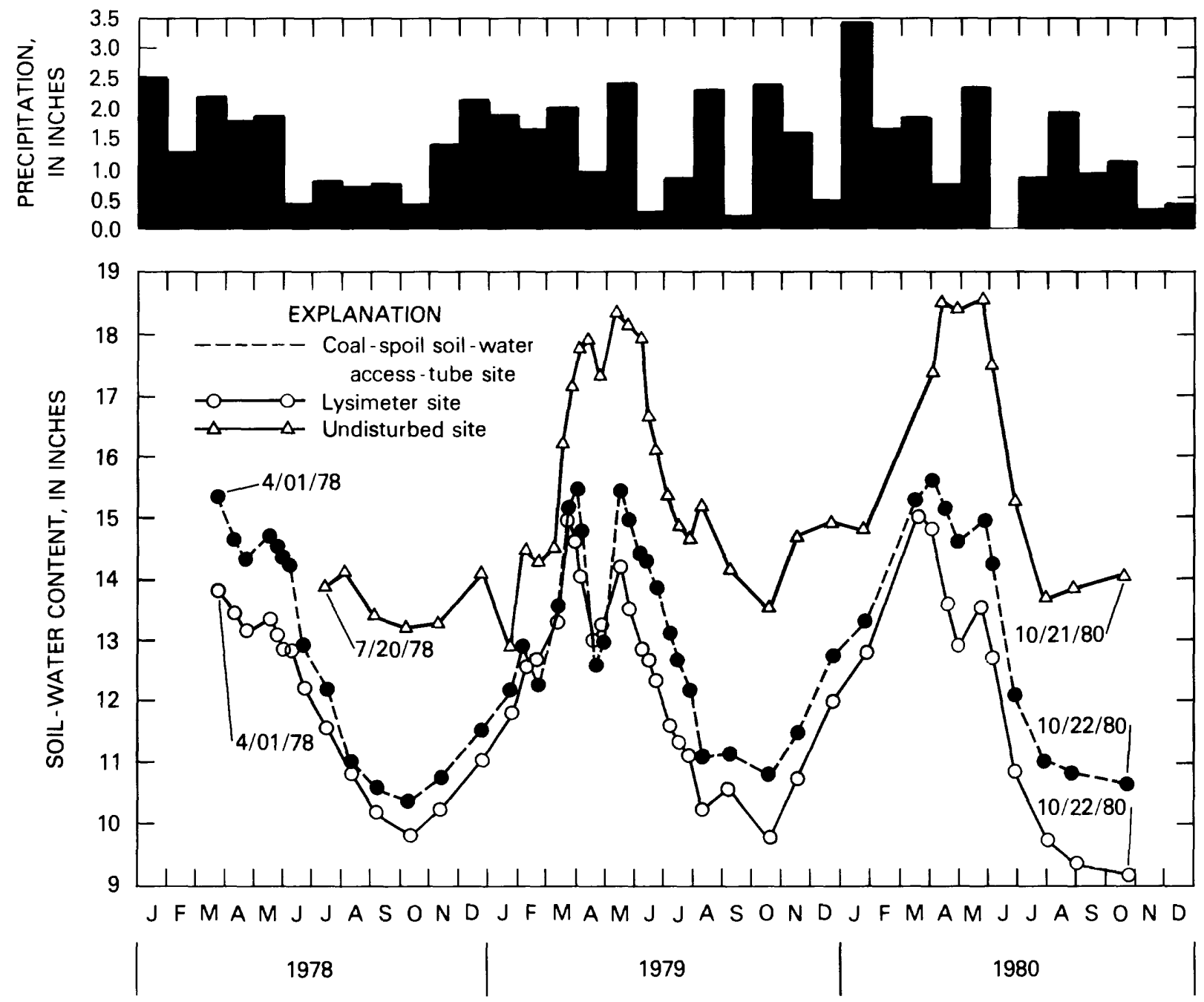

DATE OF MEASUREMENT

Figure 11.--Average soil-water content in the top 6 feet of soil for the lysimeter site, the coal-spoil soil-water access-tube site, and the undisturbed site, and monthly total precipitation. 


\section{Soil-Water Profiles}

Random replacement of broken coal-spoil material results in a nearsurface structure quite different from undisturbed soil layering and natural soil development. Water may flow differently through the two systems.

Evaluation and examination of soil-water profiles gives an indication of the soil-water content in the soil matrix. At each depth for the undisturbed site, the average total maximum and average total minimum soil-water content was calculated (fig. 12). The same calculations were made for the coal-spoil site (fig. 13).

The average maximum and the average minimum soil-water profiles of the undisturbed soil show that the largest variations in soil-water content are in the top 3 to $5 \mathrm{ft}$ of the soil surface (fig. 12). This is a dynamic zone where water uptake by plant roots (transpiration) and evaporation are the predominate factors affecting losses. Consequently, a considerable change in soilwater content can be seen in this upper zone; whereas, below this zone, a minimal change in soil-water content can be seen throughout the year.

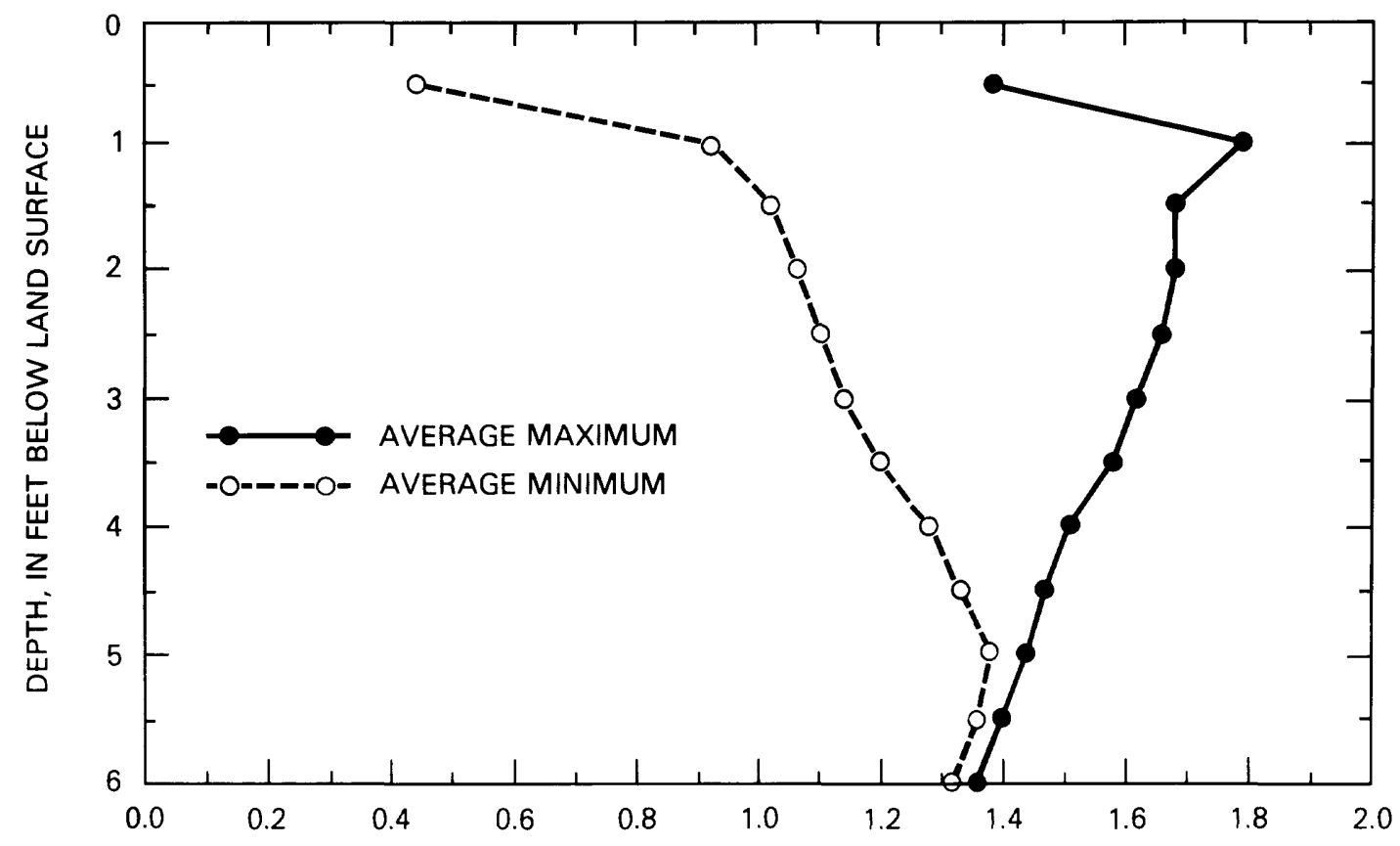

SOIL WATER, IN INCHES

Figure 12.--Comparison of average maximum and average minimum soil-water content at the undisturbed site for 1979 and 1980 . 
By contrast, the coal-spoil profile (fig. 13) is different from the undisturbed soil-water profile. The coal spoil shows the same large variation in soil-water content in the upper 3 to $5 \mathrm{ft}$ of the spoil profile, but this large variation also is present through the entire depth of measurement. Because large variations are seen throughout the profile, it is assumed that water is moving downward. This continued downward movement of water may result from different factors. The reclaimed coal spoil has much less dense and diverse vegetation than does the undisturbed soil. Therefore, transpiration demands are less. The reclaimed coal spoil does not have developed soil horizons as does the undisturbed area. The lack of soil structure and the often blocky nature of spoils enables water to move more freely downward and not be delayed or impeded by bedrock material such as the shale at the undisturbed site.

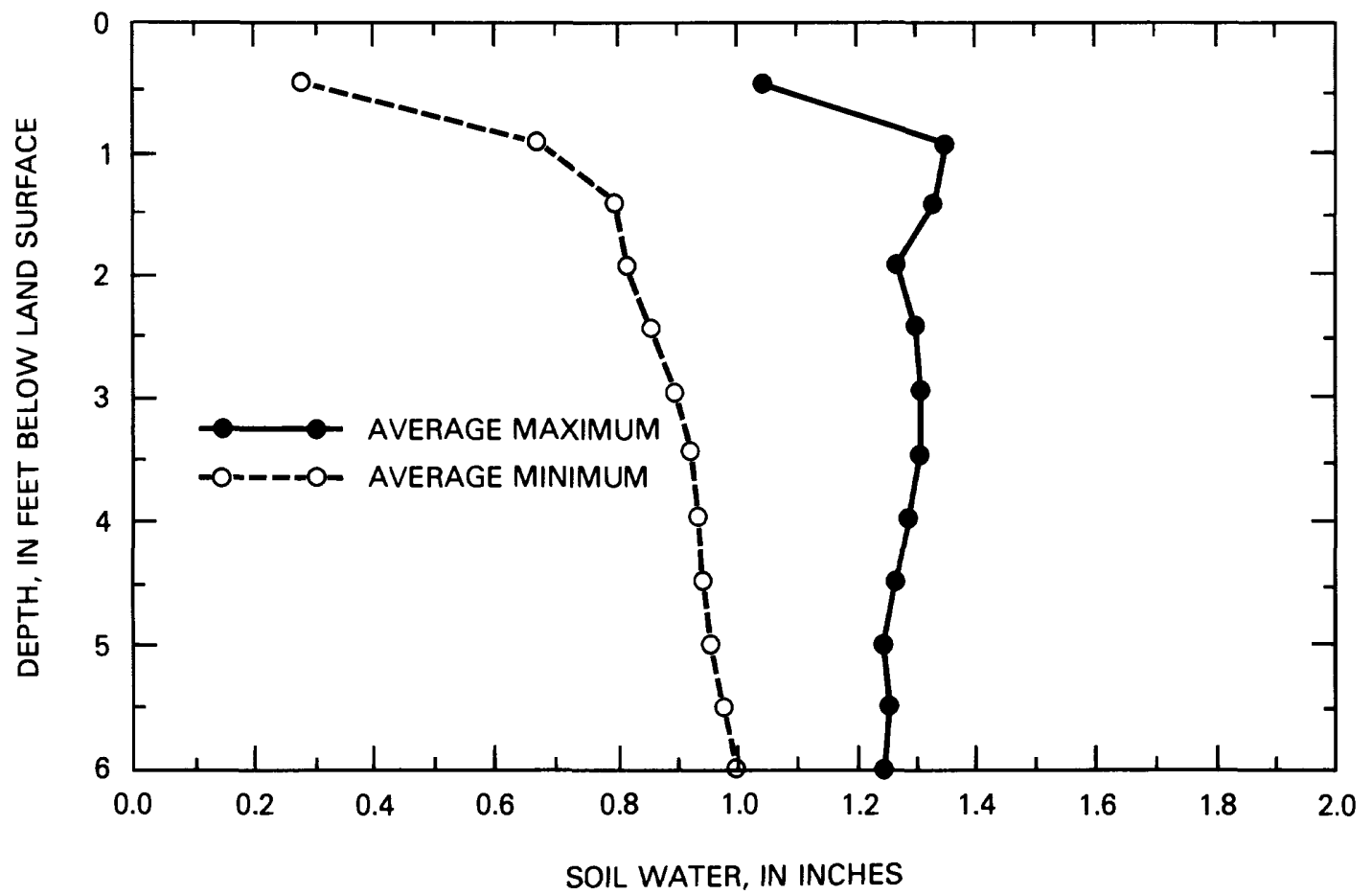

Figure 13.--Comparison of average maximum and average minimum soil-water content at the coal-spoil site for 1978, 1979, and 1980 . 
Increasing and decreasing soil-water contents through the water year at selected access tubes are shown in figures 14 through 19 . Water began entering the soil in January and moved through the soil profile until a maximum soil-water content was reached about May. Just as the soil near the surface was wetted first, this soil also was the first zone to dry out as summer months passed. Successively deeper zones did not dry out until fall.

Comparison of the porosity curves and the maximum soil-water-content curves of the coal-spoil site and the undisturbed site gives an indication of how close the systems are to saturation. The undisturbed-site curves (fig. 14 and 15) show that the soil is nearly saturated at the 4.5- to 5-ft depth. Shale underlies the site. Because shale is relatively impermeable, deep percolation probably is restricted.

The coal-spoil curves (figs. 16-19) show that the coal-spoil site (lysimeter site and coal-spoil soil-water access-tube site) does not have the nearsaturated conditions found at $5 \mathrm{ft}$ in the undisturbed site. The shale layer is not present in the coal spoil as it is in the undisturbed soil; therefore, gravity drainage of water can continue to greater depths in the coal spoil

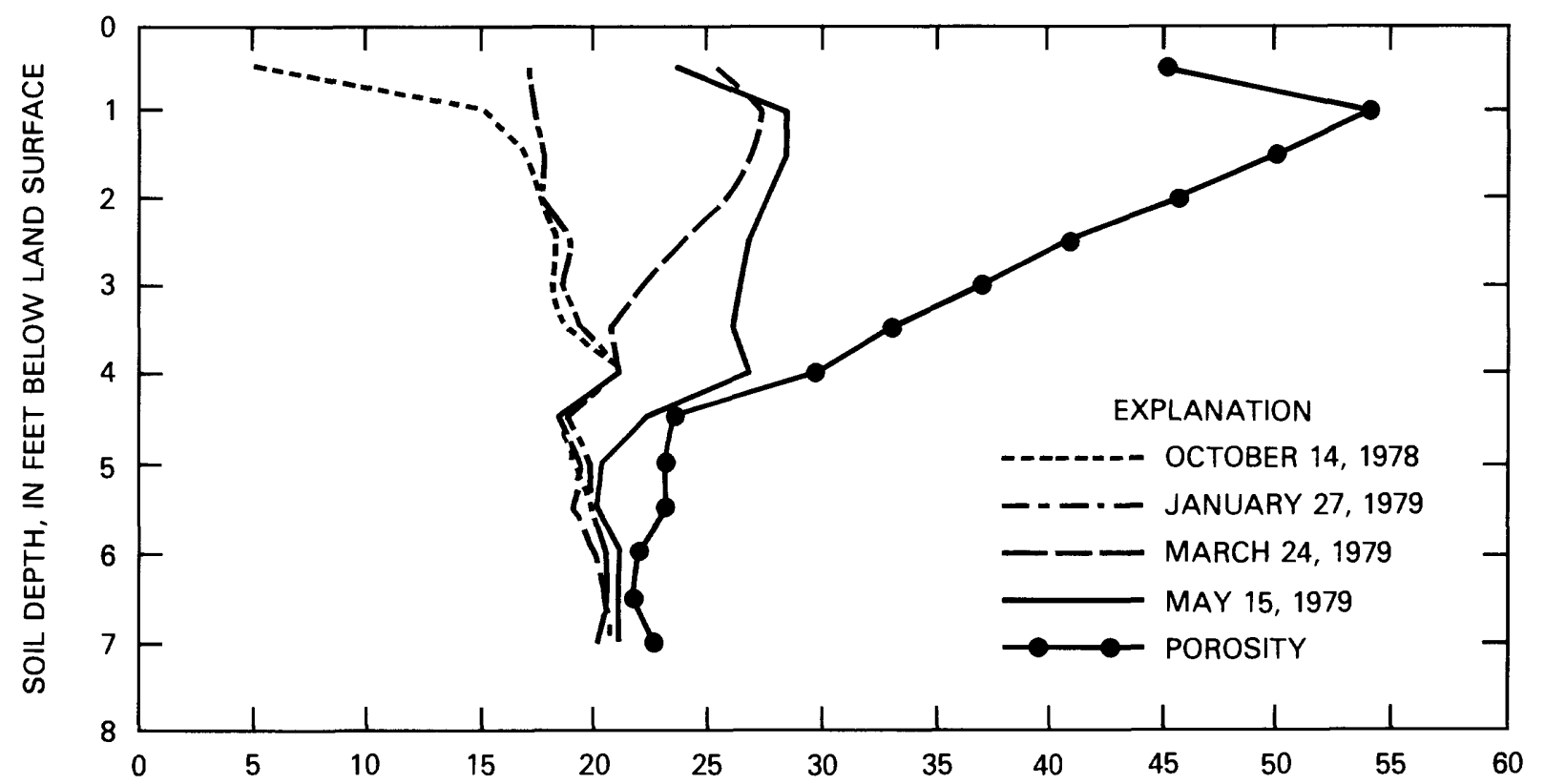

SOIL WATER AND POROSITY, IN PERCENT

Figure 14.--Increase in soil-water content: Soil depth compared to water content and soil porosity at undisturbed site, October 14, 1978 to May 15, 1979. 


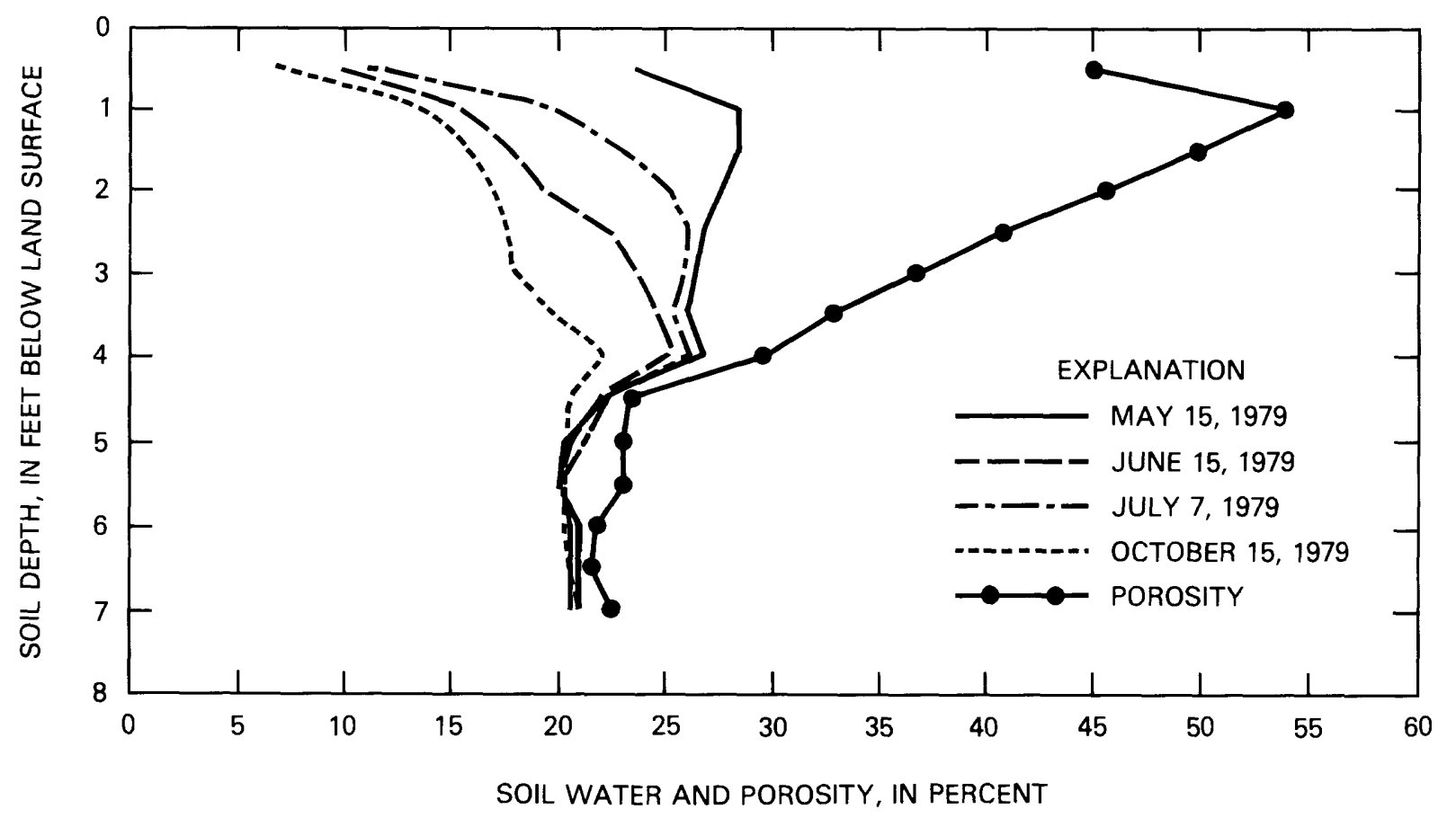

Figure 15.--Decrease in soil-water content: Soil depth compared to water content and soil porosity at undisturbed site, May 15, 1979 to October 15, 1979.

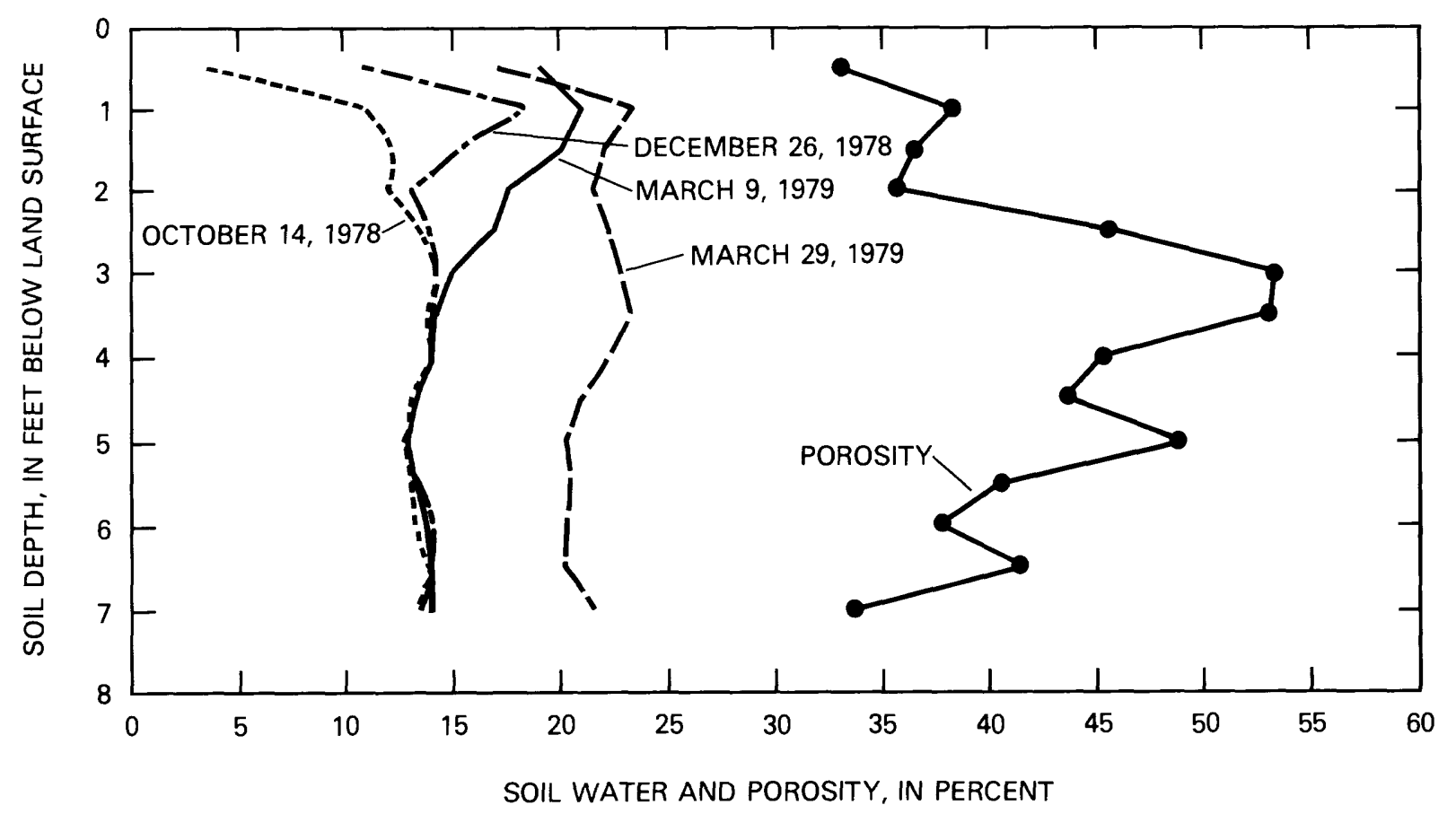

Figure 16.--Increase in soil-water content: Soil depth compared to water content and soil porosity at coal-spoil soil-water accesstube site, October 14, 1978 to March 29, 1979. 


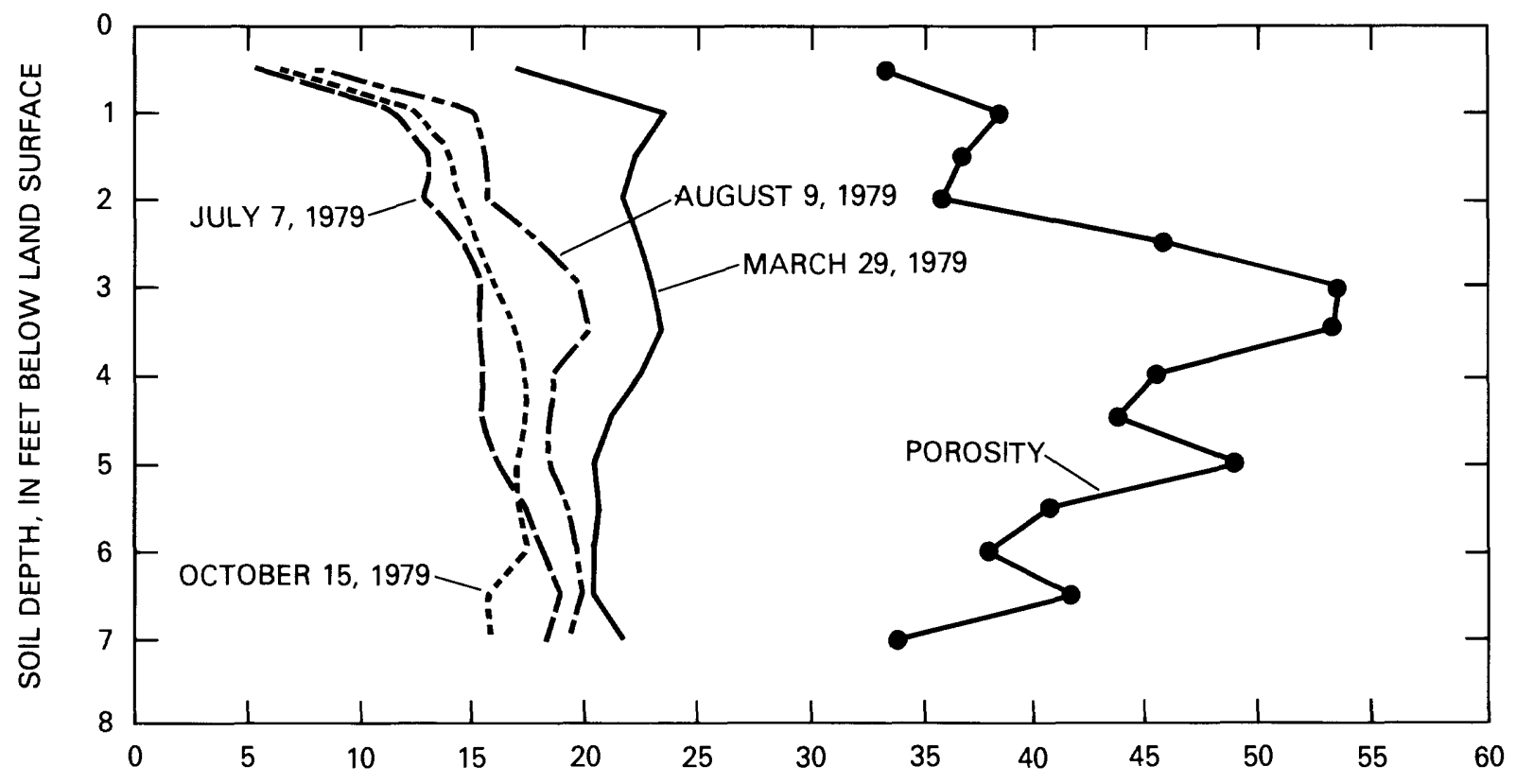

SOIL WATER AND POROSITY, IN PERCENT

Figure 17.--Decrease in soil-water content: Soil depth compared to water content and soil porosity at coal-spoil soil-water access-tube site, March 29, 1979 to October 15, 1979.

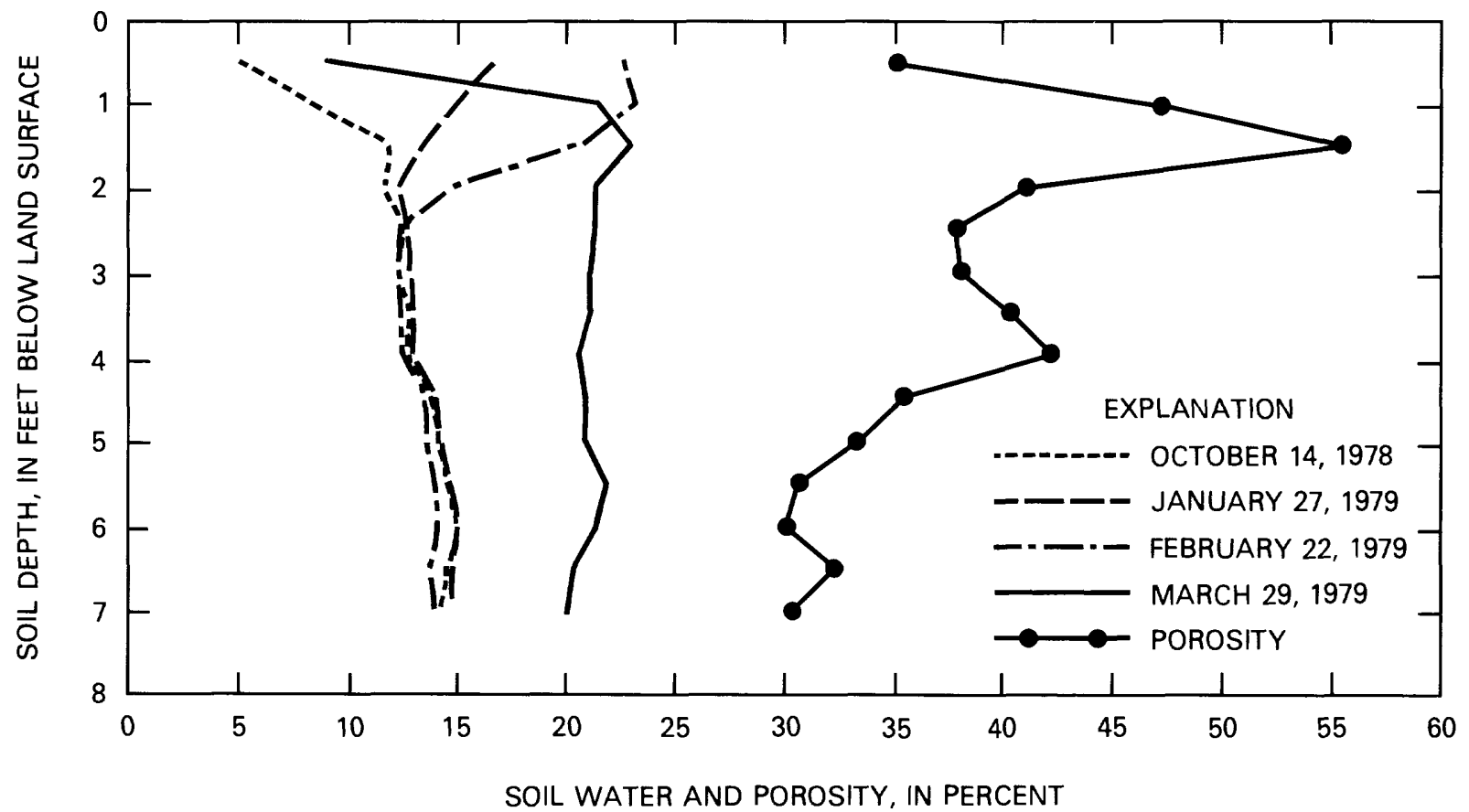

Figure 18.--Increase in soil-water content: Soil depth compared to water content and soil porosity at lysimeter site, October 14, 1978 to March 29, 1979. 


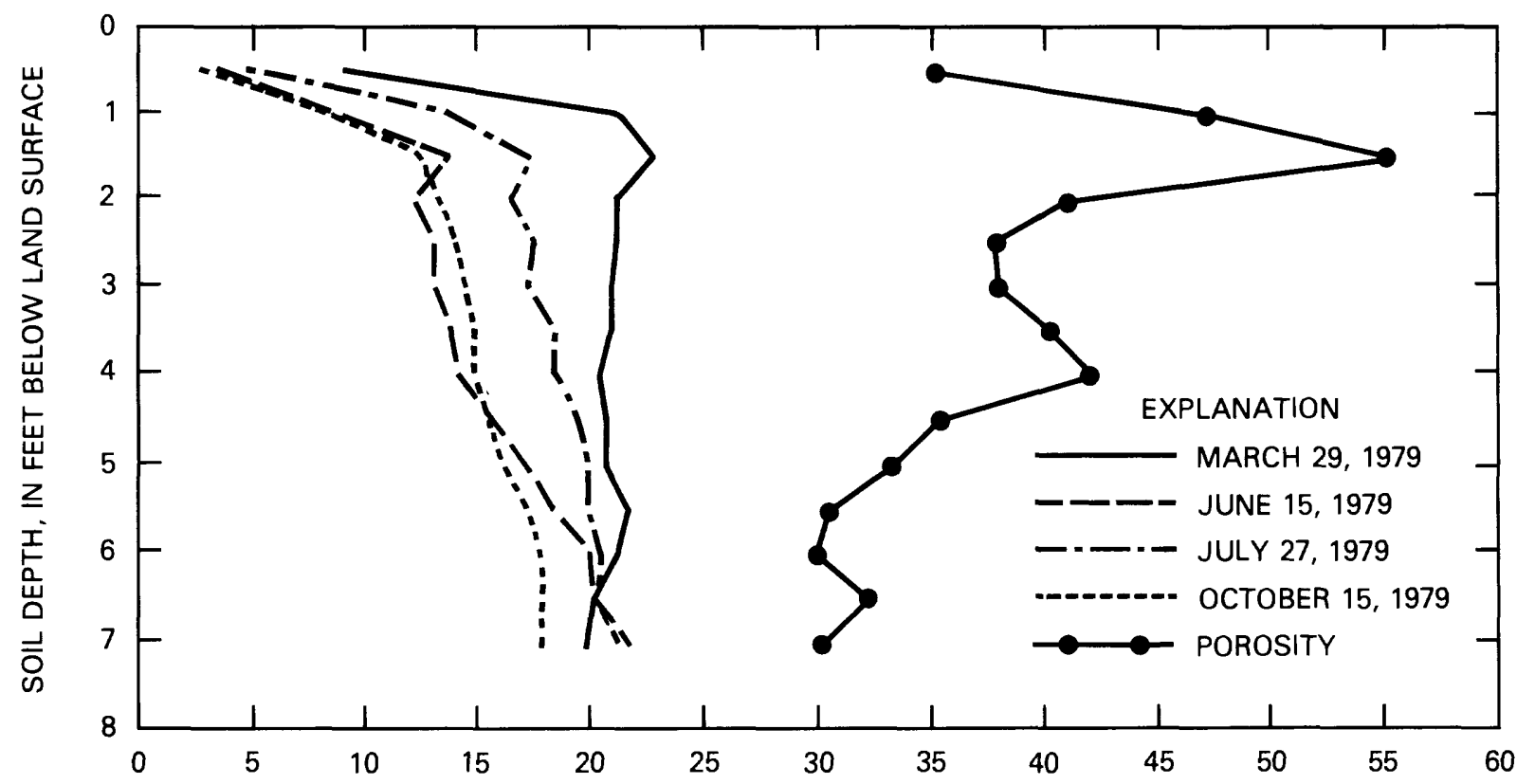

SOIL WATER AND POROSITY, IN PERCENT

Figure 19.--Decrease in soil-water content: Soil depth compared to water content and soil porosity at lysimeter site, March 29, 1979 to October 15, 1979.

more easily than in the undisturbed soil (the assumption is made that the larger change in soil-water storage indicates a greater hydraulic conductivity in the coal spoil). Once the coal-spoil water is below the rooting zone, it no longer is subject to loss by evapotranspiration. Because water in the coal spoil may percolate to greater depths more easily than in the undisturbed soil, more recharge to ground water may occur in the coal spoil. Thus, the amount of water present at different depths at certain times of the year in the coal spoil is different from the undisturbed site. Also, coal-spoil water may directly recharge underlying deeper aquifers.

\section{Soil-Water Content at the Undisturbed Site}

The undisturbed site was near saturation at depths of about 4 or $5 \mathrm{ft}$ throughout the year. Water at those depths could be part of the saturated zone (the aquifer), the tension-saturated zone (the capillary fringe), the unsaturated zone (the vadose zone), or the soil-water zone. These four zones will be considered in the following paragraphs. 
No wells are drilled at the undisturbed site. However, wells are located approximately $0.5 \mathrm{mi}$ from the site. Based on these wells and other wells in the area, it appears that the water table is 100 to $200 \mathrm{ft}$ below land surface. Therefore, the water at 4- to 5-ft depths does not represent a main aquifer or saturated zone in the area. The water probably is not the tension-saturated zone (the capillary fringe) for the main aquifer in the area, because the capillary rise would have to be greater than $100 \mathrm{ft}$.

The unsaturated zone (or the vadose zone) is located between the tensionsaturated zone and the soil-water zone. Davis and DeWiest (1966) state that the vadose zone "may be more than 1,000 feet thick in arid regions." They also note that the soil-water content in this zone can be near saturation. Based on the preceding explanation of the tension-saturated zone, the closeto-saturation conditions being measured at 4- or 5-ft depths could represent the unsaturated zone.

Davis and DeWiest (1966) also state that "...soil water is only distinguished from water in deeper unsaturated zones by the fact that it is subject to large fluctuations of quantity and quality in response to transpiration and evaporation." Clearly, the water at depths of 4 and $5 \mathrm{ft}$ is not fluctuating during the year. Therefore, the layer also is not the soil-water zone.

Based on the preceding statements, the unsaturated zone is the zone that most likely describes the water found at depths of 4 and $5 \mathrm{ft}$. The material in this zone is clay, weathered shale, and weathered siltstone. Siltstone porosity has been measured to range from 0.14 to 0.49 (Morris and Johnson, 1967). This range encompasses the porosity shown in figures 14 and 15 . Although the porosity shown in the figures is rather large for shale, it is small for clay. Whether the material is clay, shale, or siltstone, all these materials have small permeability values. Linsley and others (1975) report permeability values, in Meinzer units, for clay (0.01), shale (1), and sandstone (100). Differences in the values of permeability are one and two orders of magnitude. These permeability values may not be the same as at the undisturbed site, but they give an indication of how slowly water moves through the material at the site. So, the soil-water content being measured by the neutron probe at depths of 4 or $5 \mathrm{ft}$ probably is part of the unsaturated zone.

\section{Coal-Spoil Recharge}

Water infiltrates the broken surface of a coal spoil more easily than the natural surface of an undisturbed soil. Replaced shales, clays, and topsoil on a coal spoil can decrease infiltration.

The mean annual volume of water flowing through the lysimeters for the first 3 years after coal-spoil reclamation ranges from about 100 to $300 \mathrm{gal} /$ lysimeter. The volumes equal about 2 to 6 in. of water per unit surface area of spoil. Because the water is discharged from the base of the lysimeters, which are $8 \mathrm{ft}$ deep, the water is assumed to represent ground-water recharge because evapotranspiration losses from a depth of $8 \mathrm{ft}$ should be minimal. 
The large quantity of water flowing through the coal spoil in the lysimeters indicates water is moving downwards easily through the coal spoil. When a soil is dominated by kaolinite and illite, the infiltration-percolation rate is relatively rapid (Dollhopf and others, 1977). X-ray diffraction for the lysimeter spoil material shows kaolinite and illite to be the major clay minerals (table 1). Hounslow and others (1978) found similar clay minerology at nearby mines. Greater percolation in coal spoils containing kaolinite and illite also was reported by McWhorter and others (1977). Therefore, the large quantity of water moving through the lysimeters is reasonable.

Table 1.--Minerals or mineral groups detected by $X$-ray diffraction in coal-spoil material from locations throughout the Seneca Mine

[Units are in percent mineral present]

\begin{tabular}{|c|c|c|c|c|c|c|c|c|c|c|c|c|}
\hline \multirow{2}{*}{$\begin{array}{l}\text { Mineral or } \\
\text { mineral group }\end{array}$} & \multicolumn{12}{|c|}{ Coal-spoil sample } \\
\hline & 1 & 2 & 3 & 4 & 5 & 6 & 7 & 8 & 9 & 10 & 11 & 12 \\
\hline Quartz $\left(\mathrm{SiO}_{2}\right)$ & 42 & 35 & 46 & 43 & 36 & 34 & 42 & 38 & 38 & 25 & 59 & 45 \\
\hline Calcite $\left(\mathrm{CaCO}_{3}\right)$ & 2 & 2 & 2 & 4 & 5 & 5 & 2 & 0 & 2 & 2 & 2 & 4 \\
\hline Dolomite $\left(\mathrm{CaMg}\left(\mathrm{CO}_{3}\right)_{2}\right)$ & 3 & 4 & 4 & 4 & 4 & 4 & 3 & 2 & 3 & 2 & 4 & 2 \\
\hline Gypsum $\left(\mathrm{CaSO}_{4} \cdot 2 \mathrm{H}_{2} \mathrm{O}\right)$ & 0 & 3 & 0 & 0 & 0 & 0 & 0 & 0 & 0 & 0 & 0 & 0 \\
\hline Smectite & 0 & 0 & 0 & 0 & 0 & 0 & 0 & 0 & 0 & 0 & 0 & 0 \\
\hline Muscovite/Illite & 3 & 3 & 4 & 5 & 3 & 5 & 2 & 4 & 4 & 5 & 6 & 6 \\
\hline Chlorite & 3 & 5 & 4 & 3 & 4 & 2 & 4 & 6 & 23 & 4 & 1 & 2 \\
\hline Kaolinite & 37 & 36 & 32 & 24 & 38 & 36 & 34 & 38 & 15 & 50 & 21 & 34 \\
\hline Mixed layer clay & 1 & 2 & 2 & 1 & 1 & 2 & 2 & 1 & 1 & 1 & 0 & 0 \\
\hline Plagioclase feldspar & 8 & 5 & 4 & 8 & 3 & 4 & 7 & 9 & 6 & 3 & 5 & 3 \\
\hline Potassium feldspar & 9 & 7 & 4 & 6 & 6 & 8 & 4 & 7 & 6 & 4 & 10 & 6 \\
\hline Total percent & 98 & 102 & 102 & 98 & 100 & 100 & 100 & 105 & 98 & 96 & 108 & 102 \\
\hline
\end{tabular}

Note: The detection limits approach 1 percent for most minerals. Thus, the absence of detectable smectite, for example, only indicates that it may have been present in concentrations of less than 1 percent.

The 2 to 6 in/yr of potential ground-water recharge is substantially larger than the natural recharge of nearby undisturbed areas. Based on a mean annual precipitation of 12.71 in., a mean annual recharge of 0.66 in. was predicted for the Piceance basin (Weeks and others, 1974). Because of the similarity of the Yampa River and Piceance basins, physiographically and climatically, Warner and Dale (1982) used 0.5 in. as recharge for a groundwater model simulation of the Yampa River area. Because the study area is within the Yampa River basin, this 0.5 in. of recharge can be applied.

Comparing the expected recharge of 0.5 in. with the measured lysimeter discharge of 2 to 6 in. shows that a potential exists for considerably more recharge through a coal spoil. The result may be decreased peak flows for surface water but increased base flows. The change in distribution of runoff may supply water on a more evenly distributed basis. However, increased 
recharge may increase the dissolved-solids concentration of the base flow. The chemistry of water from the coal spoils will be discussed in the "Geochemistry" section.

More water is flowing through the coal spoil than through the undisturbed site. As the coal-spoil weathers, settles, and vegetation is reestablished, the difference between the sites may be decreased or eliminated.

A very simple coal-spoil annual water balance was calculated to examine recharge, discharge, and changes in storage in the coal spoil, assuming only vertical movement of water (table 2):

$$
E T=P C P N \pm \triangle S W C-D P R
$$

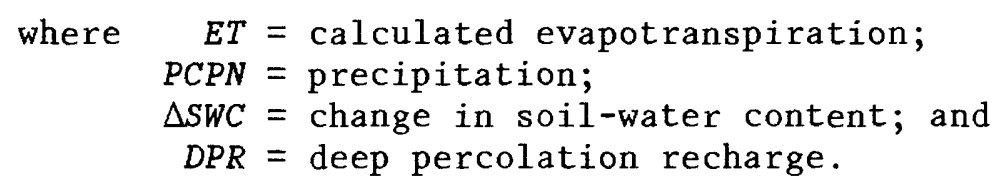

Table 2.--Coal-spoil annual water balance

[All values in inches]

\begin{tabular}{|c|c|c|c|c|c|c|}
\hline \multirow{2}{*}{$\begin{array}{l}\text { Water } \\
\text { year }\end{array}$} & \multirow{2}{*}{$\begin{array}{l}\text { Precipi- } \\
\text { tation }\end{array}$} & \multicolumn{2}{|c|}{ Soil-water content } & \multirow{2}{*}{$\begin{array}{l}\text { Change in } \\
\text { soil-water } \\
\text { content }\end{array}$} & \multirow{2}{*}{$\begin{array}{l}\text { Deep } \\
\text { perco- } \\
\text { lation } \\
\text { recharge }\end{array}$} & \multirow{2}{*}{$\begin{array}{c}\text { Evapotrans- } \\
\text { piration, } \\
\text { calculated }\end{array}$} \\
\hline & & Initial & Final & & & \\
\hline 1978 & 15.49 & 13.98 & 11.87 & -2.11 & 5.93 & 11.67 \\
\hline 1979 & 12.53 & 11.87 & 11.92 & +.05 & 3.86 & 8.62 \\
\hline 1980 & 17.92 & 11.92 & 10.99 & -.93 & 3.21 & 15.64 \\
\hline
\end{tabular}

Precipitation data were obtained from the rain gage at the coal-spoil site. Measurements of soil-water change were obtained using a neutron probe. Deep percolation was measured from flow out of the lysimeters, and evapotranspiration was calculated as a residual term. Runoff is not included in the water balance because the coal spoils have little or no runoff. Undisturbed basins in the area have approximately 1 in. of runoff per year (U.S. Geological Survey, 1983). If the water balance was extended to an entire basin, then the parts of disturbed and undisturbed areas and the associated runoff would have to be considered.

Wymore (1974) estimated actual evapotranspiration in the Piceance basin for sagebrush at 7,000 $\mathrm{ft}$ to be approximately $17.50 \mathrm{in} / \mathrm{yr}$. If the deep percolation recharge for each of the 3 years was decreased to the estimated natural recharge of 0.5 in., then the coal-spoil evapotranspiration would be 17.1 in. for $1978,11.98$ in. for 1979 , and 17.6 in. for 1980 . These values of evapotranspiration are quite close to Wymore's estimated evapotranspirations. 
Water flowing through the lysimeters decreased each year (table 3 ). Structural failure of the lysimeters, which enables leakage to occur, needs to be considered, but this failure is not believed to be the cause of decreased deep-percolation recharge. The decrease in deep-percolation recharge is probably the result of the effect of weathering on coal spoils. Weathering causes compaction and settling of coal spoil. Water moving through coal spoil will transport silt- and clay-sized soil and fill the available pore space. The result is that percolation rates will decrease, and soil water will have a longer coal-spoil residence time, thus enabling more evaporation near the coal-spoil surface and more transpiration by emergent vegetation.

Table 3.--Lysimeter deep-percolation recharge

[All values in inches]

\begin{tabular}{cccccc}
\hline & \multicolumn{5}{c}{ Lysimeter } \\
\cline { 2 - 6 } Year & 1 & 2 & 3 & \multicolumn{1}{c}{4} & 5 \\
\hline 1978 & 6.26 & 5.24 & 12.52 & 6.34 & 5.89 \\
1979 & 5.43 & 3.30 & 4.14 & 1.30 & 2.58 \\
1980 & 4.66 & 3.06 & 3.88 & 2.71 & 1.78 \\
\hline
\end{tabular}

${ }^{1}$ Equipment malfunction.

The evidence is not conclusive from this data, but the maximum soil-water content at the coal spoil may occur as much as 30 to 45 days before the maximum soil-water content at the undisturbed site (see dates on figs. 11 and 14-17). The difference is probably the result of a combined effect of different infiltration rates and time of snowmelt. Whatever the cause of the change in timing of maximum soil-water content, the timing may affect the type of vegetation that will grow on the coal spoil.

\section{GEOCHEMISTRY}

Water in the Western United States is sometimes a scarce and frequently a greatly valued commodity. The quality of the water determines what use, if any, can be made of the water. The addition of dissolved solids or salts may result in water being unacceptable for its previous use or intended use. The concentration of dissolved solids "is ordinarily determined from the weight of the dry residue remaining after evaporation of the volatile portion of an aliquot of the water sample" (Hem, 1970). The recommended concentration limit for dissolved solids in drinking water is $500 \mathrm{mg} / \mathrm{L}$ (U.S. Environmental Protection Agency, 1976). A dissolved-solids concentration greater than 2,000 to $3,000 \mathrm{mg} / \mathrm{L}$ generally is considered too salty to drink, and is classified by the U.S. Geological Survey as slightly saline to moderately saline (Robinove and others, 1958). The recommended dissolved-solids concentration limit for small livestock animals is $3,000 \mathrm{mg} / \mathrm{L}$, and the concentration limit for irrigation is $700 \mathrm{mg} / \mathrm{L}$ (National Academy of Sciences and National Academy of Engineering, 1972). 
During surface mining and the subsequent reclaiming of coal spoil, many new rock surfaces are exposed. The new surfaces then are subject to additional weathering and chemical reactions with water. Weathering as explained later in this section, will result in larger dissolved-solids concentrations. Many authors have shown that surface mining increases dissolved-solids concentrations (Curtis, 1972; Caruccio, 1973; McWhorter and others, 1974; Caruccio and Geidel, 1978; McWhorter and others, 1977; Hounslow and others, 1978). The leachate from reclaimed coal spoil eventually will come into contact with water from surrounding undisturbed areas. Depending on natural conditions, addition of leachate to surface- or ground-water supplies can alter considerably the natural water quality.

\section{Acceptance of Chemical Data}

The first step in the evaluation of chemical data is to determine the acceptability of the data base. A plot of cations (calcium, magnesium, sodium, and potassium) compared to anions (bicarbonate, sulfate, chloride, and fluoride) is shown in figure 20. One sample point appears to be an outlier. The sample was taken from lysimeter 1 during 1978 and was found to have a cation-anion milliequivalent imbalance of 38 percent. This large error was deemed excessive, and the sample was not included in the data set for this study. Lysimeter leachate water chemistry is reported for 103 samples. A11 samples were collected by U.S. Geological Survey personnel using standard U.S. Geological Survey sampling procedures and laboratory techniques (Fishman and Friedman, 1985).

\section{Lysimeter Leachate Quality}

Because the lysimeters have different textural compositions, and because lysimeters 2 and 4 have topsoil, these differences need to be considered in determining the chemical composition of the water. Only two water-quality patterns in the lysimeters are evident. The quality of water in lysimeters 4 and 5 is similar to each other and differs from that in all other lysimeters with respect to mean sodium and mean chloride concentrations, as given below, in milligrams per liter. Individual values of the chemical constituents and properties sampled are given in the "Supplementary Water-Quality Data" section at the back of the report.

\begin{tabular}{|c|c|c|c|c|c|}
\hline \multirow{2}{*}{$\begin{array}{c}\text { Ion } \\
\text { (milligrams } \\
\text { per liter) }{ }^{1}\end{array}$} & \multicolumn{5}{|c|}{ Lysimeter } \\
\hline & 1 & 2 & 3 & 4 & 5 \\
\hline Sodium & 87 & 89 & 95 & 218 & $\begin{array}{r}173 \\
80\end{array}$ \\
\hline Chloride & 7.7 & 7.5 & 6.0 & 103 & 89 \\
\hline
\end{tabular}

${ }^{1} \mathrm{~A} 11$ values are average annual concentrations for 3 years (1978, 1979, and 1980). 


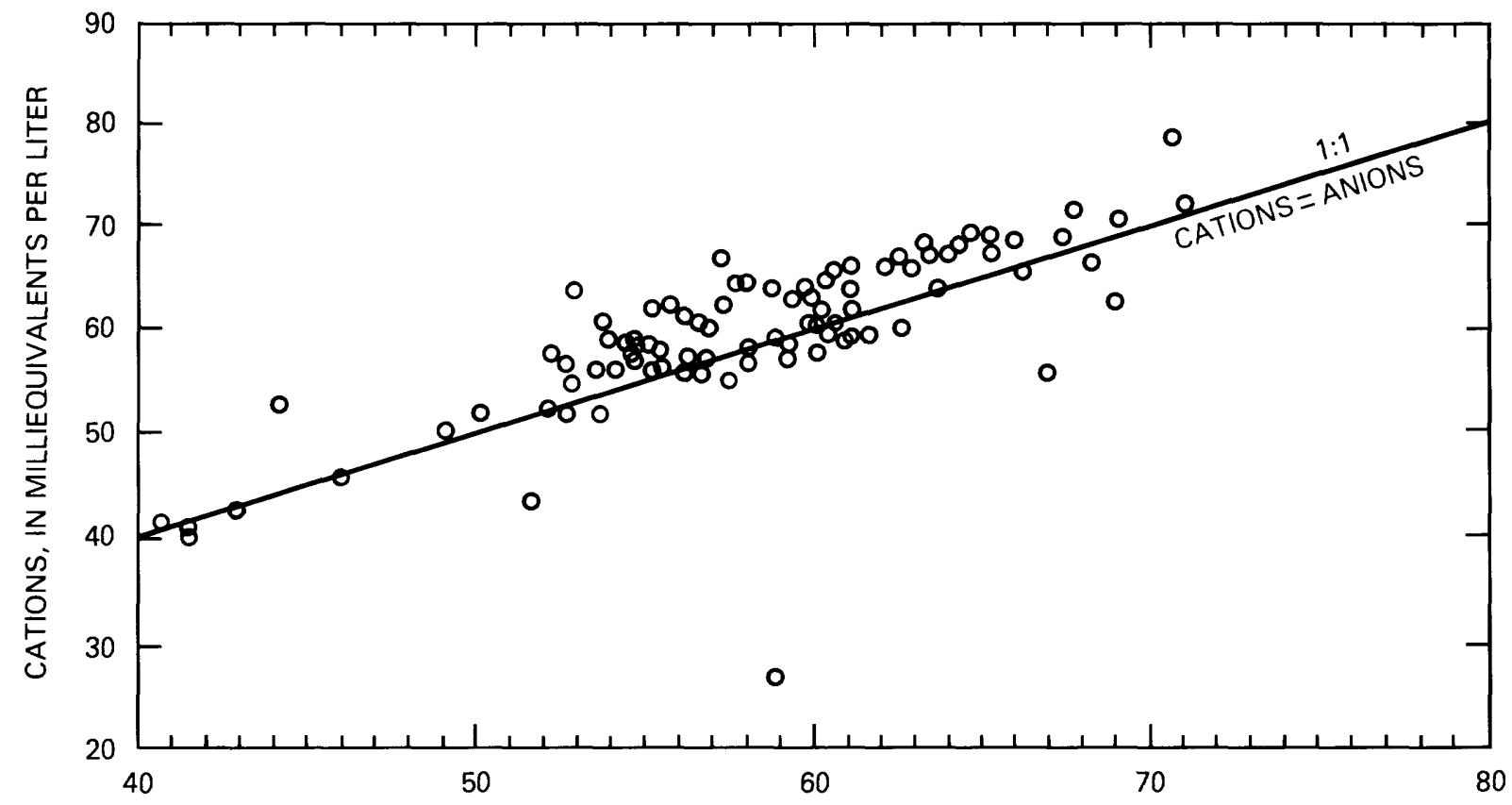

ANIONS, IN MILLEQUIVALENTS PER LITER

Figure 20.--Cations (calcium + magnesium + sodium + potassium) compared to anions (bicarbonate + sulfate + chloride + fluoride) in water from the lysimeters.

Sodium and chloride concentrations in water in lysimeters 4 and 5 are greater than those in lysimeters 1, 2, and 3. This fact indicates that the ions may originate from a similar mineral. The presence of sodium and chloride may indicate that dissolution of the evaporites, halite and natron, may be involved.

Available X-ray diffraction information does not indicate the presence of halite (table 1), and occurrence of this mineral probably is not an explanation for large concentrations in some lysimeters. However, fluid inclusions commonly occur in shales (J.E. Turk, U.S. Geological Survey, oral commun., 1984), and these inclusions could contain large concentrations of sodium and chloride ions. Rupturing of these inclusions and release of fluids in small quantities could explain why these ions occur in some water samples. It also is possible that halite is present in the spoil matrix, but that the crystals are so widely disseminated that they are not detectable by X-ray diffraction. 
The water-quality data also indicate a difference between lysimeter 2 and the other lysimeters. An example of this difference is the concentration of dissolved solids. The concentration of dissolved solids in water from lysimeter 2 is smaller than that in the other lysimeters, while the water type is essentially the same as the other lysimeters (figs. 21 and 22). It is not known whether or not this difference is the result of natural variation. Thus, minor differences in chemical-constituent concentrations occur, and negligible differences in water type occur. Therefore, the effect of textural composition and topsoil appears to have little effect on water chemistry from one lysimeter to the next.

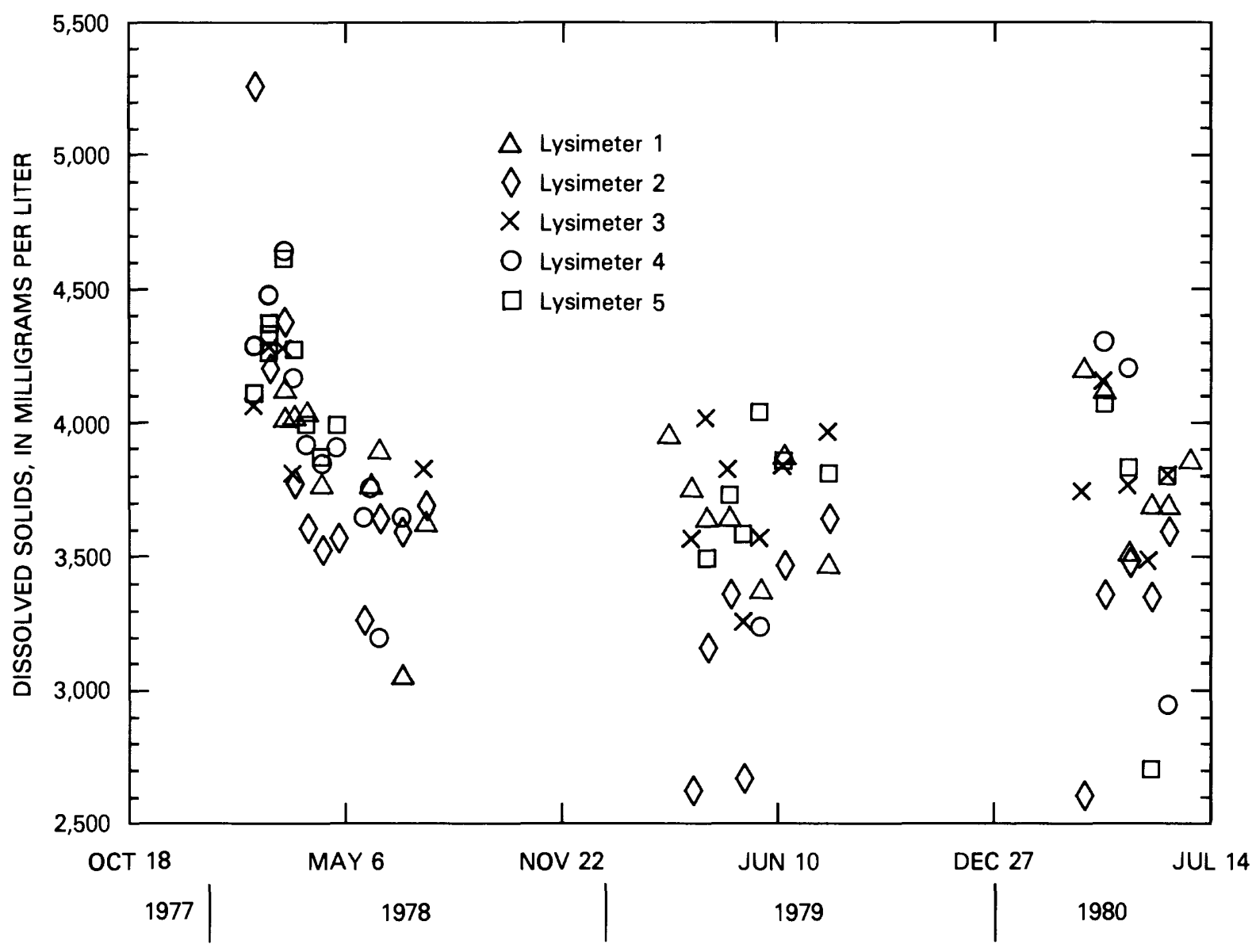

DATE SAMPLE WAS COLLECTED

Figure 21.--Dissolved-solids concentration in samples of water from the five lysimeters compared to date of collection. 


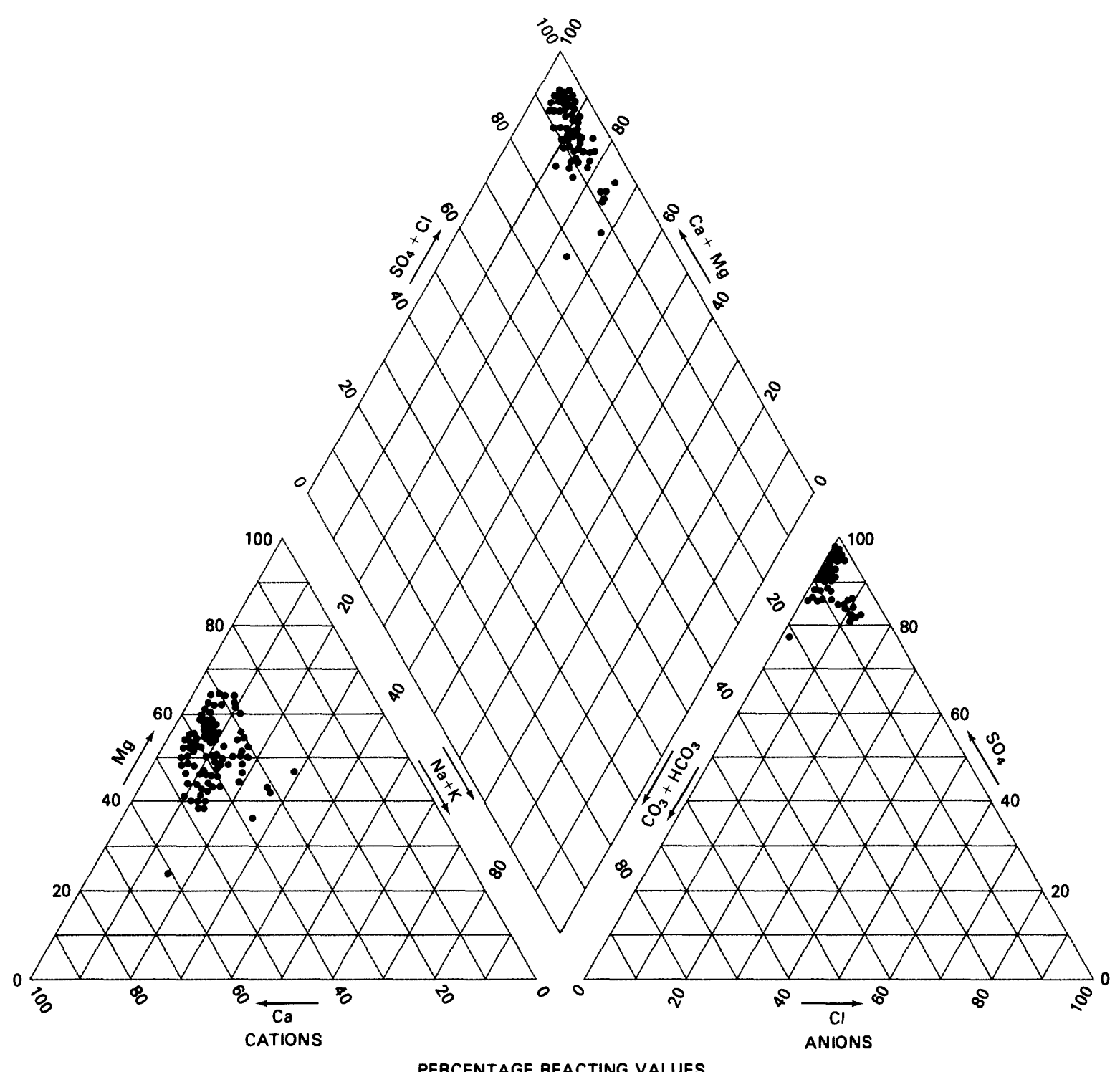

PERCENTAge REACTING VALUES

Figure 22.--Piper-trilinear diagram showing lysimeter data.

It initially was assumed that large dissolved-solids concentrations would occur in the lysimeter leachate, and with time, the readily soluble minerals would be removed from the system, resulting in smaller dissolved-solids concentrations. No clear pattern of increasing or decreasing concentrations is present. The changes that occur in concentrations simply may represent the natural variations of an average concentration. Additional years of data collection are needed before trends can be established. However, the hypothesized decrease in concentrations is not evident from these data.

Seasonal inputs, kinetics, quantity of discharge, and other factors may affect the chemical composition of the lysimeter leachate within the year. The date of collection may be important in many instances, which means that there is a within-year effect or trend with time. For example, water that remains in the lysimeter during the winter has a longer residence time than 
water flowing through the lysimeters during the spring. Consequently, there is additional time for chemical reactions and equilibration to occur.

Although minor fluctuations did occur during the year, the changes were not distinct enough to clearly identify a within-year trend.

Three conclusions from the general water chemistry are:

1. The water chemistry of all lysimeters is essentially the same; the data from these lysimeters will be analyzed as a group.

2. A difference occurs in the concentrations of ions flowing through the lysimeters on a year-to-year basis. However, the variations simply may represent natural variation.

3. The within-year variation in the water chemistry is minor.

The average concentrations of the major cations and anions in the lysimeter meter leachate were:

\begin{tabular}{lllr}
\hline \multicolumn{2}{c}{ Cations } & \multicolumn{2}{c}{ Anions } \\
\hline Calcium & $460 \mathrm{mg} / \mathrm{L}$ & Sulfate & $2,540 \mathrm{mg} / \mathrm{L}$ \\
Magnesium & $370 \mathrm{mg} / \mathrm{L}$ & Bicarbonate & $224 \mathrm{mg} / \mathrm{L}$ \\
sodium & $111 \mathrm{mg} / \mathrm{L}$ & & \\
\hline
\end{tabular}

During the summer of 1977 , the equivalent of 1 year's precipitation was applied directly as one quantity, to lysimeters $2,3,4$, and 5 . The water seemed to pipe down the walls of the lysimeters rather than saturate and flow through the spoil material. This water application then was discontinued. As has been shown, the water chemistry of lysimeter 1 is the same as lysimeters 2, 3, 4, and 5. Therefore, the application of water does not seem to have had a substantial effect on the coal-spoil water chemistry.

The first quantity of water applied was approximately 200 gal at each lysimeter, except for lysimeter 1 where no water was applied. One month later, in August, water was applied for the second and final time as follows:

$$
\begin{array}{ll}
\text { Lysimeter } & 1-0 \mathrm{gal} \\
& 2-300 \mathrm{gal} \\
3 & -200 \mathrm{gal} \\
4 & -300 \mathrm{gal} \\
5 & -400 \mathrm{gal}
\end{array}
$$

The water applied was from the Yampa River. The water was sampled before being transported in a water tank to the lysimeter site. The water from the tank was sampled before being applied to the lysimeters. The dissolved-solids concentration of the applied water was one order of magnitude less than the dissolved-solids concentration of coal-spoil water that discharged from the lysimeters. The samples associated with the water application are reported in the "Supplementary Water-Quality Data" section at the back of the report, in tables 9-22. 


\section{Dissolved-Solids Concentration}

This section will be a discussion of major cations and anions in the lysimeter leachate. The possible processes that cause the dissolved-solids concentrations also will be examined.

The average dissolved-solids concentration at the lysimeters decreased from $3,962 \mathrm{mg} / \mathrm{L}$ during 1978 to $3,560 \mathrm{mg} / \mathrm{L}$ during 1979 , but increased slightly to $3,667 \mathrm{mg} / \mathrm{L}$ during 1980 . The change probably represents just the natural fluctuations of an average value. The important consideration is evaluating the large dissolved-solids concentration.

The large dissolved-solids concentration (fig. 21) in the lysimeter leachate could inhibit plant growth on the coal spoil. The dissolved-solids concentration of the leachate also may increase concentrations in nearby natural ground- and surface-water systems.

\section{Piper-Trilinear Diagram}

A Piper-trilinear diagram depicts the ionic composition of a water sample. The points reference only percent composition and give no indication about concentrations. Therefore, a sample containing $50 \mathrm{mg} / \mathrm{L}$ of calcium, $50 \mathrm{mg} / \mathrm{L}$ of magnesium, and $50 \mathrm{mg} / \mathrm{L}$ of sodium plus potassium would plot at exactly the same point as a sample containing $5,000 \mathrm{mg} / \mathrm{L}$ of each of the named cations. The water quality of the samples obtained from the lysimeters is presented in tables 4-8 (in the "Supplementary Water-Quality Data" section at the back of the report). The homogeneity of the ionic composition of the samples is shown by the clustering of the points on the Piper-trilinear diagram in figure 22. The samples are strongly dominated by calcium, magnesium, and sulfate ions.

\section{Sources of Dissolved Solids}

Calcium, magnesium, and sulfate are the dominant ions in the coal-spoil leachate. The cations, calcium and magnesium, probably come from carbonate minerals that have been dissolved by carbonic acid or sulfuric acid. Carbonic acid is formed naturally when carbon dioxide gas $\left(\mathrm{CO}_{2}\right)$ dissolves in water. Sources of carbon dioxide are the atmosphere, decaying organic matter, and plant respiration. Sulfuric acid is formed by the oxidation and dissolution of minerals such as pyrite $\left(\mathrm{FeS}_{2}\right)$. Gypsum is a source of sulfate.

\section{Atmospheric Carbon Dioxide, Decay of Organic Matter, and Plant Respiration}

The atmospheric partial pressure of carbon dioxide $\left(\mathrm{PCO}_{2}\right)$ is approximately $10^{-3.5} \mathrm{~atm}$. Therefore, water from precipitation that enters the coal spoil should have a $\mathrm{PCO}_{2}$ of about $10^{-3.5} \mathrm{~atm}$. If the $\mathrm{PCO}_{2}$ of water in the coal spoil is greater than $10^{-3.5} \mathrm{~atm}$, then the indication is that $\mathrm{CO}_{2}$ is being added within the coal spoil during percolation. The subsurface sources 
of $\mathrm{CO}_{2}$ would be decay of organic matter, plant respiration, and dissolution of carbonates by sulfuric acid. Production of $\mathrm{CO}_{2}$ by oxidation of organic matter commonly is expressed by:

$$
\mathrm{CH}_{2} \mathrm{O}+\mathrm{O}_{2} \rightarrow \mathrm{CO}_{2}+\mathrm{H}_{2} \mathrm{O} \text {. }
$$

However, the coal spoil had little vegetation and contained very little freshly deposited organic matter during the study.

If $\mathrm{PCO}_{2}$ is less than atmospheric $\mathrm{PCO}_{2}$, that indicates the coal spoil assimilates $\mathrm{CO}_{2}$ faster than it is replaced. $\mathrm{PCO}_{2}$ levels may decline because of mineral-water reactions. The $\mathrm{CO}_{2}$ combines with water to form carbonic acid $\left(\mathrm{H}_{2} \mathrm{CO}_{3}\right)$. The carbonic acid then dissociates:

$$
\begin{aligned}
\mathrm{H}_{2} \mathrm{CO}_{3} & \rightarrow \mathrm{H}^{+}+\mathrm{HCO}_{3}^{-} . \\
\mathrm{HCO}_{3}^{-} & \rightarrow \mathrm{H}^{+}+\mathrm{CO}_{3}^{-2} .
\end{aligned}
$$

The slightly acidic environment then facilitates the dissolution of carbonate rocks, such as calcite and dolomite. As a result, carbonic acid and $\mathrm{CO}_{2}$ are consumed, and calcium, magnesium, and bicarbonate ions are released to solution.

For example, the equations for calcite and for dolomite dissolution are:

$$
\begin{aligned}
& \mathrm{CaCO}_{3}+\mathrm{H}_{2} \mathrm{CO}_{3} \rightarrow \mathrm{Ca}^{+2}+2 \mathrm{HCO}_{3}^{-} . \\
& \mathrm{CaMg}\left(\mathrm{CO}_{3}\right)_{2}+2 \mathrm{H}_{2} \mathrm{CO}_{3} \rightarrow \mathrm{Ca}^{+2}+\mathrm{Mg}^{+2}+4 \mathrm{HCO}_{3}^{-} .
\end{aligned}
$$

Without additional $\mathrm{CO}_{2}$ being introduced to the deeper soil water, the $\mathrm{PCO}_{2}$ concentration will decrease.

The spoil material in the lysimeters was not saturated with water. Therefore, atmospheric $\mathrm{CO}_{2}$ should have been able to enter the spoil-material pore space and combine with water to form carbonic acid throughout the lysimeter depth. Thus, the coal spoil was an open rather than a closed system.

Both Garrels and Christ (1965) and Krauskopf (1979) show methods to calculate ion concentrations that result from calcite dissolution by carbonic acid. Similar calculations can be made for dolomite. However, the calculated concentrations are smaller than are present in the lysimeter leachate. Krauskopf (1979) notes that, when comparing theoretically derived numbers to actual measured concentrations in natural waters, the measured concentrations "are embarrassingly high, much higher than can be accounted for even with generous assumptions about temperature, $\mathrm{CO}_{2}$ pressure, and acidity." $\mathrm{He}$ attributes the large concentrations of carbonate derived ions to be mainly the result of both the effect of other electrolytes in solution and ion association. 
Considering the preceding comments of Krauskopf (1979), dissolution of calcite and dolomite by carbonic acid could account for the calcium and magnesium found in the lysimeter leachate. Dissolution of these minerals does not account for the presence of sulfate. However, dissolution of gypsum or pyrite can account for the sulfate in the solution.

\section{Mineral Weathering}

Gypsum.--Sulfate is an ion that comprises a large percentage of the dissolved-solids load. One source of the sulfate is gypsum. Gypsum is ubiquitous in the study area, and even small quantities of gypsum could account for the concentrations of sulfate found in the lysimeter leachate.

Pyrite oxidation.--Pyrite also is a possible source of sulfate. Pyrite that is present in the shallow coal spoil can be oxidized:

$$
2 \mathrm{FeS}_{2}+7 \mathrm{O}_{2}+2 \mathrm{H}_{2} \mathrm{O} \rightarrow 2 \mathrm{Fe}^{+2}+4 \mathrm{SO}_{4}^{-2}+4 \mathrm{H}^{+} \text {. }
$$

The sulfuric acid then forms from this reaction and can dissolve carbonate rocks containing calcite:

$$
2 \mathrm{CaCO}_{3}+\mathrm{H}_{2} \mathrm{SO}_{4} \rightarrow 2 \mathrm{Ca}^{+2}+2 \mathrm{HCO}_{3}^{-}+\mathrm{SO}_{4}^{-2} ;
$$

or dolomite:

$$
\mathrm{CaMg}\left(\mathrm{CO}_{3}\right)_{2}+\mathrm{H}_{2} \mathrm{SO}_{4} \rightarrow \mathrm{Ca}^{+2}+\mathrm{Mg}^{+2}+\mathrm{SO}_{4}^{-2}+2 \mathrm{HCO}_{3}^{-} .
$$

The sulfate ions produced in the above reactions may remain in solution and may be transported in recharge water to a deeper aquifer. Alternatively, if evapotranspiration is occurring, gypsum may precipitate within the coal spoil:

$$
\mathrm{Ca}+2+\mathrm{SO}_{4}^{-2}+2 \mathrm{H}_{2} \mathrm{O} \rightarrow \mathrm{CaSO}_{4} \cdot 2 \mathrm{H}_{2} \mathrm{O} \text {. }
$$

Subsequent infiltration of water can redissolve the precipitated gypsum. Even if pyrite is present in concentrations less than 1 percent, this presence still could account for all the sulfate present in the coal-spoil water.

Carbonic-acid dissolution of carbonate rocks, combined with gypsum dissolution, may be the major reactions in the system; or, more likely, these reactions and pyrite oxidation could be occurring simultaneously. The water chemistry of the lysimeter leachate probably is the result of a carbon-dioxide driven system, gypsum dissolution, and pyrite oxidation.

Following carbonate dissolution, dissolved ions may flow from the coal spoil, or they may precipitate following evapotranspiration as the source mineral or a different mineral. Plots of saturation indices, as calculated by WATEQF (Plummer and others, 1976), are compared to date for selected minerals (figs. 23, 24, and 25). Values plotted are the saturation indices where zero indicates the equilibrium condition. A saturated condition means if the mineral is present, it is in equilibrium with the solution and should not undergo additional dissolution. Calcite, dolomite, and gypsum generally are 


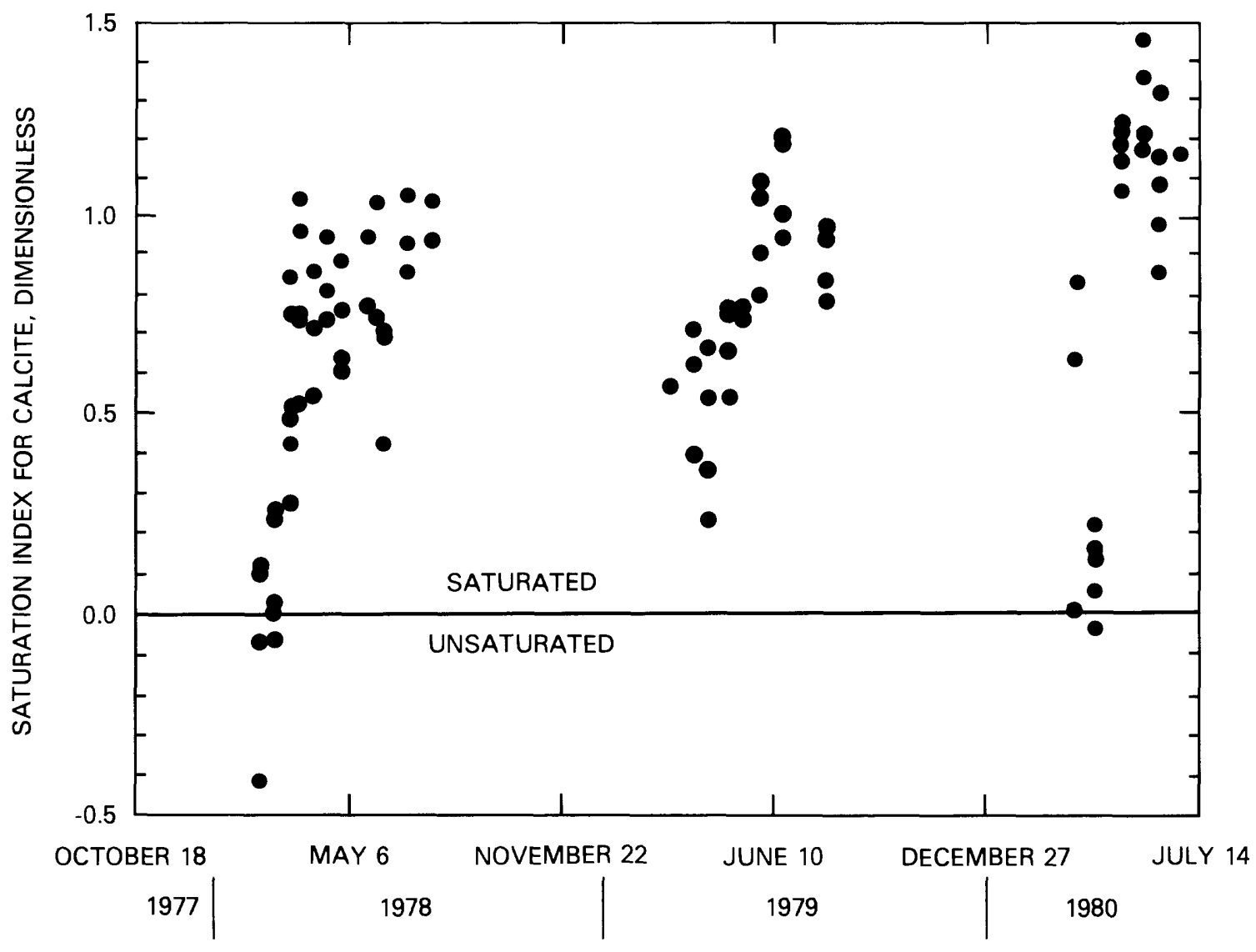

DATE SAMPLES COLLECTED

Figure 23.--Saturation indices for calcite compared to date samples were collected from the lysimeters.

saturated in the waters in the lysimeters and minerals should not dissolve any further. However, in the future, gypsum may dissolve in the presence of less-mineralized water; thus, gypsum can be a long-term source of calcium and sulfate.

Another process that could occur in a coal spoil is cation exchange. In this process, calcium and magnesium are exchanged for adsorbed sodium and potassium on the clays in shales that are abundant in the coal spoil. For example:

$$
\mathrm{Na}_{2}(\mathrm{Clay})+\mathrm{Ca}^{+2} \rightarrow \mathrm{Ca}(\mathrm{Clay})+2 \mathrm{Na}^{+} .
$$




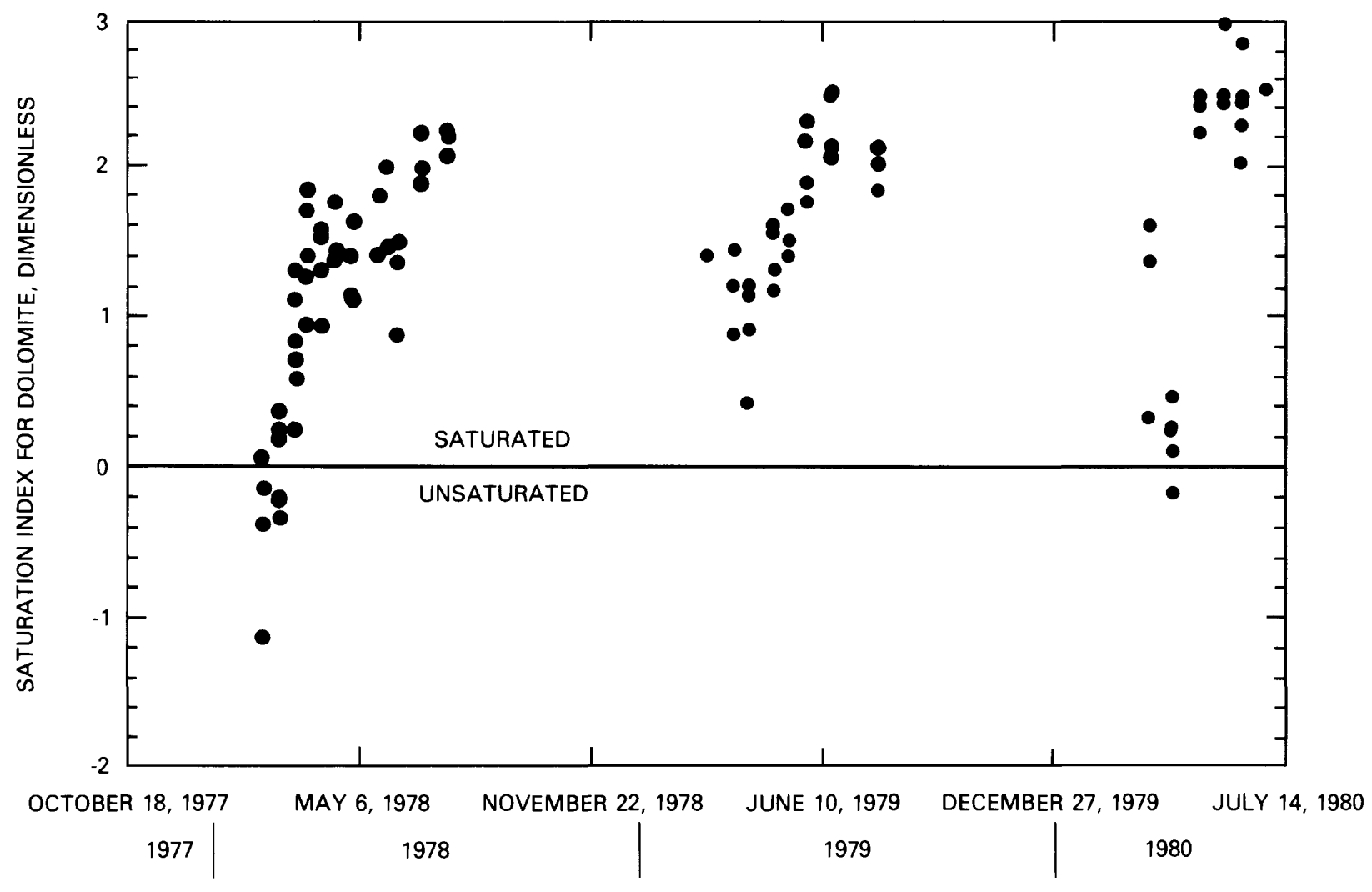

DATE SAMPLES COLLECTED

Figure 24.--Saturation indices for dolomite compared to date samples were collected from the lysimeters.

Therefore, cation exchange can help account for the presence of sodium and potassium in the coal-spoil leachate. However, the small concentration of these ions indicates that cation exchange is not a major process occurring in the lysimeters.

Still another process that could occur in the coal spoils is the weathering of potassium and sodium feldspars to kaolinite, which releases potassium and sodium to solution. The weathering is a very slow process compared to cation exchange. 


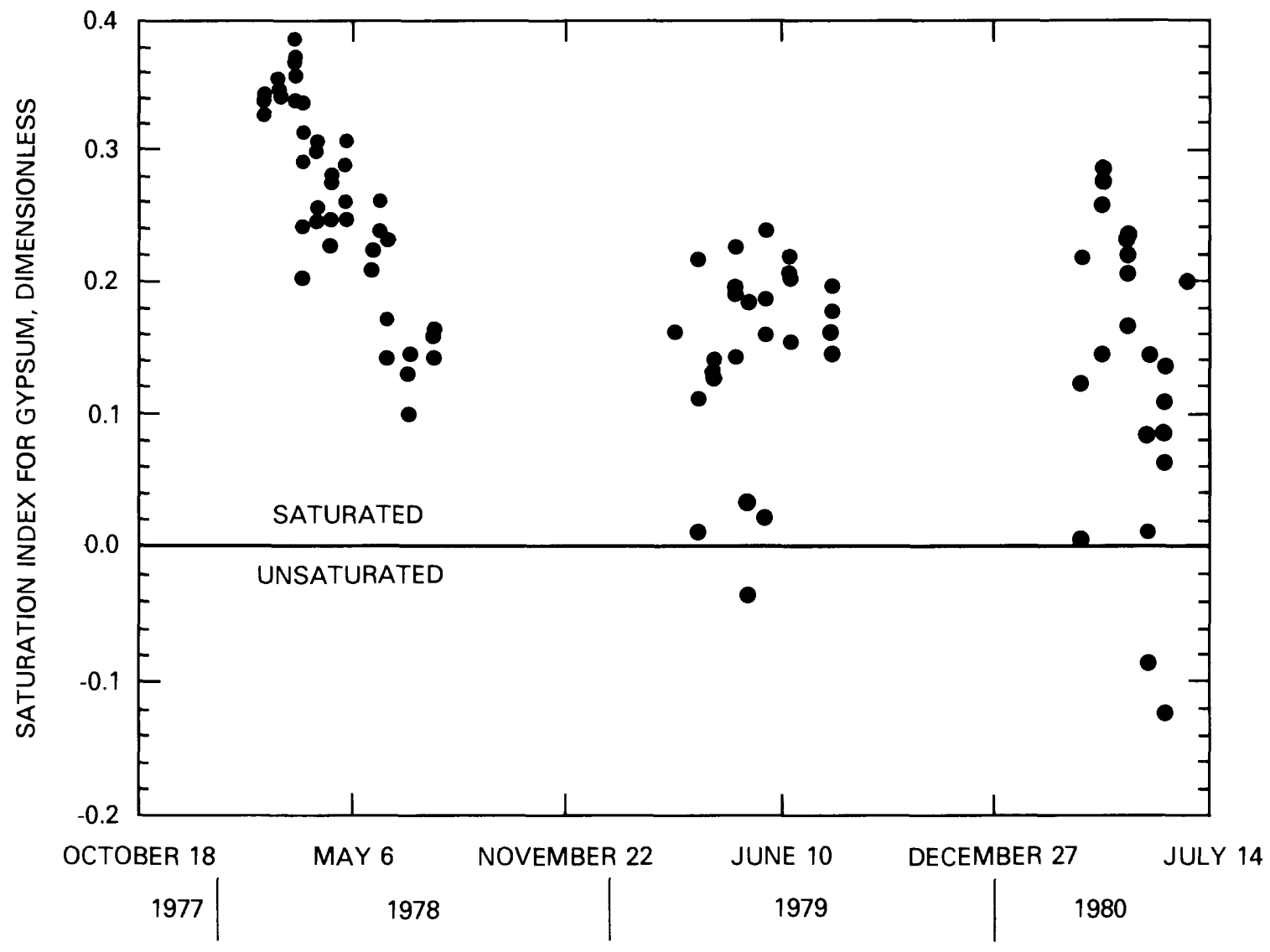

DATE SAMPLES COLLECTED

Figure 25.--Saturation indices for gypsum compared to date samples were collected from the lysimeters.

In addition to the cations and anions previously discussed, nitrogen (dissolved nitrite plus nitrate, as nitrogen), and selenium are in large concentrations in the lysimeter leachate. The large nitrogen concentrations were present only in samples collected during the early part of the study; whereas, the large selenium concentrations were present in all samples collected. 
The U.S. Environmental Protection Agency (1976) limit for concentrations of dissolved nitrate as nitrogen for domestic water supply is $10 \mathrm{mg} / \mathrm{L}$, and large concentrations of dissolved nitrate as nitrogen can cause methemoglobinemia in infants. Large concentrations of dissolved nitrate as nitrogen in the coal spoils may be due to intense fertilization of the coal spoils by the mine operators. The study area had just been recontoured and reclaimed following mining, and revegetation activities were ongoing. The following table shows the rapid decline in dissolved-nitrogen con-centrations after 1978 .

\begin{tabular}{lrrrrr}
\hline & \multicolumn{5}{c}{ Lysimeter } \\
\cline { 2 - 6 } & 1 & 2 & 3 & 4 & 5 \\
\hline 1978 & 49 & 43 & 51 & 25 & 36 \\
1979 & 15 & 7 & 2 & 8 & 2 \\
1980 & 3 & 8 & 1 & 1 & $<1$ \\
\hline
\end{tabular}

Note: All values are average annual concentrations in milligrams per liter $(\mathrm{mg} / \mathrm{L})$ of nitrogen (dissolved nitrite plus dissolved nitrate as nitrogen), for 3 years (1978, 1979, 1980).

Concentrations of selenium should not exceed $10 \mu \mathrm{g} / \mathrm{L}$ for domestic water supplies (U.S. Environmental Protection Agency, 1976). Although selenium is essential and beneficial to man, excessive concentrations are considered toxic and have symptoms that are similar to arsenic poisoning. The concentration of selenium in the lysimeter leachate exceeded $10 \mu \mathrm{g} / \mathrm{L}$ for all but one sample, and average selenium concentrations were one order of magnitude greater than the U.S. Environmental Protection Agency standards for drinking water supplies.

\begin{tabular}{cc}
\hline Lysimeter & $\begin{array}{c}\text { Average } \\
\text { selenium } \\
\text { concentration }\end{array}$ \\
\hline 1 & $174 \mu \mathrm{g} / \mathrm{L}$ \\
2 & $169 \mu \mathrm{L}$ \\
3 & $128 \mu \mathrm{L} / \mathrm{L}$ \\
4 & $105 \mu \mathrm{L} / \mathrm{L}$ \\
5 & $161 \mu \mathrm{L}$ \\
\hline
\end{tabular}

In addition to exceeding drinking water standards, these large selenium concentrations may preclude other uses of the water from the coal spoils, because selenium can be taken up by plants, which if consumed by livestock or wildlife may be harmful. 
Water quantity and water quality in a coal spoil and an adjacent undisturbed site in northwestern Colorado were compared, using 5 drainage-type lysimeters and 21 soil-water access tubes at the coal spoil and 8 access tubes at the undisturbed site. The coal spoil had one access tube in each lysimeter and eight access tubes in the coal spoil near the lysimeters. The study was made during the first 3 years after reclamation.

Soil-water content was measured to a depth of $6 \mathrm{ft}$ with a neutron probe. The quantity of water that entered the coal spoil and the undisturbed soil was about the same. However, the rate at which water flowed through the systems and the quantity of water present at different depths at certain times of the year were different. Comparison of measured average total maximum and average total minimum soil-water content and soil porosity showed that the undisturbed soil was near saturation throughout the year at depths of about 4.5 to $5 \mathrm{ft}$. Soil-water content at the 6-ft depth varied by 1 to 3 percent during the year. Because weathered shale occurs below this depth, a minimal quantity of water percolates to recharge deeper aquifers. In contrast, the coal spoil was not near saturation, and water moved freely to a depth of at least $6 \mathrm{ft}$. Soil-water content at the 6-ft depth varied from 5 to 7 percent during the year. In fact, at a depth of $8 \mathrm{ft}, 2$ to 6 in. of water per unit surface area per year was percolating through the lysimeters and potentially could have recharged deeper aquifers. The natural recharge to aquifers in the area was estimated to be about $0.5 \mathrm{in} / \mathrm{yr}$. Even though the differences between measured potential coal-spoil recharge and the undisturbed-soil estimated recharge may have seemed large, it needs to be noted that these values were for the first 3 years after reclamation. Subsequent weathering of the spoil, coal-spoil settling, vegetation development, and other factors may reduce coal-spoil recharge in the future.

Although the lysimeter coal-spoil material varied in texture, and 8 to 18 in. of topsoil was initially applied to two of the five lysimeters, the chemical composition of the leachate remained initially the same. No differences in chemical concentrations were detected from year-to-year or within any year. The average concentrations of the major ions in the leachate were: calcium, $460 \mathrm{mg} / \mathrm{L}$; magnesium, $370 \mathrm{mg} / \mathrm{L}$; sulfate, 2,540 mg/L; sodium, $111 \mathrm{mg} / \mathrm{L}$; and bicarbonate, $224 \mathrm{mg} / \mathrm{L}$.

Carbonic-acid dissolution of carbonate rocks, dissolution of gypsum, and cation exchange on clays can account for concentrations of the major cations and anions found in the lysimeter leachate. Atmospheric carbon dioxide is the major source of carbon dioxide for forming carbonic acid. The carbonic acid then dissolves calcite and dolomite and results in calcium, magnesium, and bicarbonate in solution. Gypsum dissolution results in calcium and sulfate in solution. 
Pyrite oxidation also could initiate the chemical reactions that account for the quality of coal-spoil water. Sulfuric acid is formed during pyrite oxidation. The acid then dissolves carbonate minerals such as calcite and dolomite. After reaction of the acid with carbonates, the coal-spoil water may become saturated with gypsum, and authigenic precipitation of gypsum can follow. The result is that the precipitated gypsum, in addition to the gypsum already present in the spoil, could continue to be a source of calcium and sulfate for a long time. The water chemistry of the coal spoil probably is the result of combined effects of carbonate dissolution by a carbondioxide-driven process, pyrite oxidation, and dissolution of gypsum. The small quantities of sodium and potassium present indicate that cation exchange may be occurring on the clays present; however, the exchange is a minor factor in the overall coal-spoil water chemistry. 


\section{REFERENCES CITED}

American Geological Institute, 1976, Bibliography and index of Colorado geology, 1875 to 1975: Denver, Colorado Geological Survey, Bulletin 37, $488 \mathrm{p}$.

Bass, N.W., Eby, J.B., and Campbell, M.R., 1955, Geology and mineral fuels of parts of Routt and Moffat Counties, Colorado: U.S. Geological Survey Bulletin 1027-D, p. 143-250, scale $1: 62,500$.

Berg, W.A., Brown, J.A., and Cuany, R.L., Co-chairmen, 1974, Revegetation of high-altitude disturbed lands proceedings: Fort Collins, Colorado State University, Environmental Resources Center, Information Series 10, $88 \mathrm{p}$.

Berman, A.E., Poleschook, D., Jr., and Dimelow, T.E., 1980, Jurassic and Cretaceous systems of Colorado, in Kent, H.C., and Porter, K.W., eds., Colorado geology: Rocky Mountain Association of Geologists Guide Book, p. $111-128$.

Boettcher, A.J., 1972, Ground-water occurrence in northern and central parts of western Colorado: Colorado Water Conservation Board, Water Resources Circular $15,25 \mathrm{p}$.

Brogden, R.E., and Giles, T.F., 1977, Reconnaissance of ground-water resources in a part of the Yampa River basin between Craig and Steamboat Springs, Moffat and Routt Counties, Colorado: U.S. Geological Survey WaterResources Investigations 77-4, map, scale 1:125,000.

Buckman, H.O., and Brady, N.C., 1969, The nature and properties of soils, 7 th ed.: New York, The Macmillian Co., $653 \mathrm{p}$.

Campbe11, M.R., 1923, The Twentymile Park district of the Yampa coal field, Routt County, Colorado: U.S. Geological Survey Bulletin 748, 82 p.

Caruccio, F.T., 1973, Characteristics of strip mine drainage by pyrite grain size and chemical quality of ground water, in Hutnik, R.J., and Davis, Grant, eds., Ecology and reclamation of devastated land: New York, Gordon and Breach, p. 193-226.

Caruccio, F.J., and Geidel, G., 1978, Geochemical factors affecting coal mine drainage quality, in Schaller, F.W., and Sutton, Paul, eds., Reclamation of drastically disturbed lands: American Society of Agronomy, p. 129-148.

Cook, C.W., and Bonham, C.D., 1977, Techniques for vegetation measurements and analysis for a pre- and post-mining inventory: Fort Collins, Colorado State University, Range Science Department, Science Series 28, 94 p.

Cook, C.W., Hyde, R.M., and Sims, P.L., 1974, Guidelines for revegetation and stabilization of surface mined areas in the western States: Fort Collins, Colorado State University, Range Science Department, Science Series $16,73 \mathrm{p}$.

Covay, K.J., and Tobin, R.L., 1981, Quality of ground water in Routt County, northwestern Colorado: U.S. Geological Survey Water-Resources Investigations Open-File Report 80-956, 38 p.

Curtis, W.R., 1972, Chemical changes in streamflow following surface mining in eastern Kentucky, in Fourth Symposium on coal mine drainage reservoir, Pittsburgh, Pa.: $\overline{M o n} r o e v i l l e, P a .$, Bituminous Coal Resources, Inc., p. 19-31.

Dames and Moore, 1980a, Coal-resource occurrence and coal-development potential maps of the Milner quadrangle, Routt County, Colorado: U.S. Geological Survey Open-File Report 79-815, 33 p. $1980 \mathrm{~b}$, Coal-resource occurrence and coal-development maps of the Mount Harris quadrangle, Routt County, Colorado: U.S. Geological Survey Open-File Report 79-825, 27 p. 
Davis, S.N., and DeWiest, R.J., 1966, Hydrogeology: New York, John Wiley and Sons, Inc., $463 \mathrm{p}$.

Dollhopf, D.J., Jensen, I.B., and Hodder, R.L., 1977, Effects of surface configuration in water pollution control and semiarid mined lands: Bozeman, Montana State University, Montana Agricultural Experiment Station, Research Report 114, 179 p.

ENMAP Corp., 1981, Guide to Colorado's weather and climate: Boulder, Colo., Map pamphlet.

Ficke, J.F., Weeks, J.B., and Welder, F.A., 1974, Hydrologic data from the Piceance basin, Colorado: Colorado Water Conservation Board WaterResources Basic-Data Release 31, 246 p.

Fishman, M.J., and Friedman, L.C., eds., 1985, Methods for determination of inorganic substances in water and fluvial sediments: U.S. Geological Survey Open-File Report 85-495, 709 p.

Gaffke, J.M., 1979, Depositional environments of a coal-bearing section in the Upper Cretaceous Mesaverde Group, Routt County, Colorado: U.S. Geological Survey Open-File Report 79-1669, 15 p.

Gardner, W., and Kirkham, Don, 1952, Determination of soil moisture by neutron scattering: Soil Science, v. 73, p. 391-401.

Garrels, R.M., and Christ, C.L., 1965, Solutions, minerals, and equilibria: New York, Harper and Row, $450 \mathrm{p}$.

Gaydos, M.W., 1980, Summary of water-quality data for selected streams in Colorado: U.S. Geological Survey Water-Resources Investigations Open-File Report 80-682, 148 p.

Giles, T.F., and Brogden, R.E., 1978, Selected hydrologic data, Yampa River basin and parts of the White River basin, northwestern Colorado and south-central Wyoming: U.S. Geological Survey Open-File Report 78-23, $91 \mathrm{p}$.

Hem, J.D., 1970, Study and interpretation of the chemical characteristics of natural water (2d ed.): U.S. Geological Survey Water-Supply Paper 1473, $363 \mathrm{p}$.

Hounslow, Arthur, Fitzpatrick, Joan, Cerrillo, Lawrence, and Freeland, Michael, 1978, Overburden mineralogy as related to ground-water chemical changes in coal strip mining: U.S. Environmental Protection Agency report 600/7-78-156, $229 \mathrm{p}$.

Iorns, W.V., Hembree, C.H., and Oakland, G.L., 1965, Water resources of Upper Colorado River Basin--Technical report: U.S. Geological Survey Professional Paper 441, 370 p.

Jackson, C.L, and Schuster, M.A., eds., 1980, High-altitude revegetation workshop No. 4 proceedings: Fort Collins, Colorado State University, Water Resources Research Institute, Information Series 42, 258 p.

Kenny, S.T., ed., 1978, High-altitude revegetation workshop No. 3 proceedings: Fort Collins, Colorado State University, Environmental Resources Center, Information Series 28,213 p.

Krauskopf, K.B., 1979, Introduction to geochemistry, (2d ed): New York, McGraw-Hill Book Co., 617 p.

Linsley, R.K., Kohler, M.A., and Paulhus, J.L.H., 1975, Hydrology for Engineers (2d ed.): New York, McGraw-Hill Book Co., 482 p.

McWhorter, D.B., Rowe, J.W., Van Liew, M.W., Chandler, R.L., Skogerboe, R.K., Sunada, D.K., and Skogerboe, G.V., 1977, Surface and subsurface water quality hydrology in surface mines watersheds. Part I. Text, Part II. Appendices: Fort Collins, Colorado State University, Agricultural Engineering and Chemistry Departments Reports, 313 p. 
McWhorter, D.B., Skogerboe, G.V., and Skogerboe, R.K., 1974, Water pollution potential of mine spoils in the Rocky Mountain Region, in Fifth Symposium on coal mine drainage reservoir Louisville, Kentucky: Washington, D.C., National Coal Association, p. 25-38.

Merriam, R.A., 1960, Moisture sampling in wildland soils with a neutron probe: Iowa State Journal of Science, v. 34, no. 4, p. 641-648.

Miller, A.E., 1975, Geology energy and mineral resources of Routt County, Colorado: Denver, Colorado Geological Survey, Map Series 1, 2 maps, scale $1: 126,720$ and $1: 500,000$.

Misbach, G.T., 1972, Water quality survey of the Yampa River: Colorado Department of Health, Water Pollution Control Division, $14 \mathrm{p}$.

Moran, R.E., and Wentz, D.A., 1974, Effects of metal-mine drainage on water quality on selected areas of Colorado, 1972-73: Colorado Water-Resources Circular 25, $250 \mathrm{p}$.

Morris, D.A., and Johnson, A.I., 1967, Summary of hydrologic and physical properties of rock and soil materials as analyzed by the hydrologic laboratory of the U.S. Geological Survey, 1948-60: U.S. Geological Survey Water-Supply Paper 1839-D, p. D1-D42.

National Academy of Sciences and National Academy of Engineering, 1972[1974], Water quality criteria: Washington, D.C., U.S. Government Printing Office, $594 \mathrm{p}$.

National Oceanic and Atmospheric Administration, 1982, Climatological data, annual summary, Colorado, 1982: Ashville, N.C., National Climatic Data Center, $30 \mathrm{p}$.

Parsons, H.F., and Liddell, C.A., 1903, Coal and mineral resources of Routt and Moffat Counties, Colorado: Denver, Colorado Geological Survey Bulletin 24, 76 p.

Pearl, R.H., 1974, Geology of ground water resources in Colorado: Denver, Colorado Geological Survey, 47 p.

Plummer, L.N., Jones, B.F., and Truesdell, A.H., 1976, WATEQF: A FORTRAN IV version of WATEQ, a computer program for calculating chemical equilibrium of natural waters: U.S. Geological Survey Water-Resources Investigations $76-13,61 \mathrm{p}$.

Robinove, C.J., Langford, R.H., and Brookhart, J.W., 1958, Saline-water resources of North Dakota: U.S. Geological Survey Water-Supply Paper $1428,72 \mathrm{p}$.

Robson, S.G., and Saulnier, G.J., Jr., 1981, Hydrogeochemistry and simulated solute transport, Piceance basin, northwestern Colorado: U.S. Geological Survey Professional Paper 1196, 65 p.

Ryer, T.A., 1977, Geology and coal resources of the Foidel Creek EMRIA site and surrounding area, Routt County, Colorado: U.S. Geological Survey Open-File Report 77-303, 31 p.

Schaller, F.W., and Sutton, Paul, eds., 1978, Reclamation of drastically disturbed lands: American Society of Agronomy, $742 \mathrm{p}$.

Steele, T.D., Bauer, D.P., Wentz, D.A., and Warner, J.W., 1979, The Yampa River basin, Colorado and Wyoming--A preview to expanded coal-resource development and its impacts on regional water resources: U.S. Geological Survey Water-Resources Investigations 78-126, $133 \mathrm{p}$.

Steele, T.D., and Hillier, D.E., 1981, Assessment of impacts of proposed coal-resource and related economic development on water resources, Yampa River basin, Colorado and Wyoming--A summary: U.S. Geological Survey Circular 839,56 p. 
Soilmoisture Equipment Corp., 1976, Brochure: Post Office Box 30025, Santa Barbara, Calif.

Turk, J.T., 1982, Thermodynamic controls on quality of water from underground coal mines in Colorado: Water Resources Bulletin, American Water Resources Association, v. 18 no. 1, p. 75-80.

Turk, J.T., and Parker, R.S., 1982, Water quality characteristics of six small, semiarid watersheds in the Green River coal region of Colorado: U.S. Geological Survey Water-Resources Investigations 81-19, $96 \mathrm{p}$.

Tweto, Ogden, 1976, Geologic map of the Craig $1^{\circ} \times 2^{\circ}$ quadrangle, northwestern Colorado: U.S. Geological Survey Miscellaneous Investigations Series Map I-972, scale 1:250,000.

U.S. Environmental Protection Agency, 1976, National interim primary drinking water regulations: U.S. Environmental Protection Agency 570/9-76-003, $159 \mathrm{p}$.

U.S. Geological Survey, 1983, Water-resources data for Colorado--Water year 1982, Volume 3. Dolores River basin, Green River basin, and San Juan River basin: U.S. Geological Survey Water-Data Report C0-82-3, 366 p.

Van Bavel, C.H., Underwood, N., and Swanson, R.W., 1956, Soil moisture measurement by neutron probe moderation: Soil Science, v. 82, p. 29-41.

Warner, J.W., and Dale, R.H., 1982, Digital-transport model study of the potential effects of coal-resource development on the ground-water system in the Yampa River basin, Moffat and Routt Counties, Colorado: U.S. Geological Survey Water-Resources Investigations 81-15, $70 \mathrm{p}$.

Weeks, J.B., 1978, Digital model of ground-water flow in the Piceance basin, Rio Blanco and Garfield Counties, Colorado: U.S. Geological Survey Water-Resources Investigations $78-46,108 \mathrm{p}$.

Weeks, J.B., Leavesley, G.H., Welder, F.A., and Saulnier, G.J., Jr., 1974, Simulated effects of oil-shale development on the hydrology of Piceance basin, Colorado: U.S. Geological Survey Professional Paper 908, 84 p.

Weeks, J.B., and Welder, F.A., 1974, Hydrologic and geophysical data from the Piceance basin, Colorado: Colorado Water Conservation Board, Water Resources Basic-Data Release 35, $121 \mathrm{p}$.

Wentz, D.A., 1974, Effect of mine drainage on the quality of streams in Colorado, 1971-72: U.S. Geological Survey, Colorado Water-Resources Circular 21, $117 \mathrm{p}$.

Wentz, D.A., and Steele, T.D., 1980, Analysis of stream quality in the Yampa River basin, Colorado and Wyoming: U.S. Geological Survey WaterResources Investigations 80-8, $161 \mathrm{p}$.

Wymore, T.F., 1974, Estimated average annual water balance for Piceance and Yellow Creek watersheds: Fort Collins, Colorado State University, Envi ronmental Resources Center, Technical Report 2, 60 p.

Zuck, R.H., and Brown, L.F., eds., 1976, High altitude revegetation workshop No. 2 Proceedings: Fort Collins, Colorado State University, Environmental Resources Center, Information Series 21, 128 p. 
SUPPLEMENTARY WATER-QUALITY DATA 
The following abbreviations are used in tables 4-22.

${ }^{\circ} \mathrm{C}$, degree Celsius

$\mu \mathrm{S} / \mathrm{CM}$, microsiemens per centimeter at 25 degrees Celsius

$M G / L$, milligram per liter

FET-FLD, Fixed end-point titration-field

$\mu G / L$, microgram per liter

IT-LAB, incremental titration-laboratory

--, no data

$<$, less than

ND, not detected

$\mathrm{AC}-\mathrm{FT}$, acre foot

RECOV., recoverable 
Table 4.--Water-quality data from Lysimeter 1

\begin{tabular}{|c|c|c|c|c|c|c|c|c|c|c|c|c|}
\hline \multirow{2}{*}{\multicolumn{2}{|c|}{ DATE }} & \multicolumn{6}{|c|}{ WATER-QUALITY DATA, WATER YEAR OCTOBER 1977} & \multicolumn{3}{|c|}{ TO SEPTEMBER 1978} & \multirow[b]{2}{*}{$\begin{array}{l}\text { HARD- } \\
\text { NESS } \\
\text { (MG/L } \\
\text { AS } \\
\text { CAC03) }\end{array}$} & \\
\hline & & $\begin{array}{l}\text { TEMPER- } \\
\text { ATURE } \\
\left({ }^{\circ} \mathrm{C}\right)\end{array}$ & $\begin{array}{l}\text { SPE- } \\
\text { CIFIC } \\
\text { CON- } \\
\text { DUCT- } \\
\text { ANCE } \\
(\mu \mathrm{S} / \mathrm{CM})\end{array}$ & $\begin{array}{l}\text { OXYGEN, } \\
\text { DIS- } \\
\text { SOLVED } \\
\text { (MG/L) }\end{array}$ & $\begin{array}{c}\mathrm{pH} \\
\text { (STAND- } \\
\text { ARD } \\
\text { UNITS) }\end{array}$ & $\begin{array}{c}\text { CARBON } \\
\text { DIOXIDE } \\
\text { DIS- } \\
\text { SOLVED } \\
(\text { MG/L } \\
\text { AS CO2) }\end{array}$ & $\begin{array}{c}\text { CAR- } \\
\text { BONATE } \\
\text { FET-FID } \\
(M G / L \\
\text { AS CO3) }\end{array}$ & $\begin{array}{c}\text { NITRO- } \\
\text { GEN } \\
\mathrm{NO}_{2}+\mathrm{NO}_{3} \\
\text { DIS- } \\
\text { SOLVED } \\
(\mathrm{MG} / \mathrm{L} \\
\mathrm{AS} \mathrm{N})\end{array}$ & $\begin{array}{l}\text { PHOS- } \\
\text { PHATE, } \\
\text { ORTHO, } \\
\text { DIS- } \\
\text { SOLVED } \\
\text { (MG/L } \\
\text { AS PO4) }\end{array}$ & $\begin{array}{l}\text { PHOS- } \\
\text { PHORUS, } \\
\text { ORTHO, } \\
\text { DIS- } \\
\text { SOLVED } \\
\text { (MG/L } \\
\text { AS P) }\end{array}$ & & \\
\hline \multicolumn{13}{|c|}{ MAR } \\
\hline & $11 \cdots$ & 2.0 & 4,080 & 10.2 & 7.8 & 6.6 & 0 & 84 & .00 & $<.010$ & 2,700 & \\
\hline & $11---$ & 2.0 & 4,080 & 10.2 & 7.9 & 5.2 & 0 & 86 & .00 & $<.010$ & 2,800 & \\
\hline & $20 \cdots$ & 3.5 & 4,240 & 9.8 & 7.8 & 6.6 & 0 & 100 & .06 & .020 & 2,900 & \\
\hline \multicolumn{13}{|c|}{ APR } \\
\hline & $01 \ldots$ & 5.0 & 4,230 & 9.8 & 7.5 & 16 & 0 & 69 & .40 & .130 & 3,200 & \\
\hline & $15 \cdots-\cdots$ & 6.0 & 3,910 & 9.5 & 7.9 & 4.2 & 0 & 36 & .03 & .010 & 2,900 & \\
\hline & \multicolumn{11}{|l|}{ MAY } & \\
\hline & $23 \cdots \cdots$ & 9.5 & 3,720 & 8.4 & 8.0 & 3.4 & 0 & 25 & .00 & $<.010$ & -- & \\
\hline & $30 \cdots$ & 10.0 & 3,880 & 8.4 & 8.0 & 2.2 & 0 & 26 & .03 & .010 & 2,800 & \\
\hline \multicolumn{13}{|c|}{ JUN } \\
\hline & $07 \cdots$ & 10.5 & 3,870 & 8.3 & 7.8 & 3.6 & 0 & 28 & .00 & $<.010$ & 2,500 & \\
\hline & $28 \cdots \cdots$ & 18.0 & 3,890 & 6.6 & 8.3 & 1.2 & 0 & 26 & .03 & .010 & 2,400 & \\
\hline & \multicolumn{11}{|l|}{ JUL } & \\
\hline & $20----$ & 18.0 & 3,900 & 6.6 & 8.3 & 1.2 & 0 & 26 & .00 & $<.010$ & 2,600 & \\
\hline DATE & $\begin{array}{l}\text { HARD- } \\
\text { NESS, } \\
\text { NONCAR- } \\
\text { BONATE } \\
\text { (MG/L AS } \\
\text { CACO3) }\end{array}$ & $\begin{array}{c}\text { CALCIUM } \\
\text { DIS- } \\
\text { SOLVED } \\
\text { (MG/L } \\
\text { AS CA) }\end{array}$ & $\begin{array}{l}\text { MAGNE- } \\
\text { SIUM, } \\
\text { DIS- } \\
\text { SOLVED } \\
\text { (MG/L } \\
\text { AS MG) }\end{array}$ & $\begin{array}{l}\text { SODIUM, } \\
\text { DIS- } \\
\text { SOLVED } \\
\text { (MG/L } \\
\text { AS NA) }\end{array}$ & $\begin{array}{c}\text { SODIUM } \\
\text { AD- } \\
\text { SORP- } \\
\text { TION } \\
\text { RATIO }\end{array}$ & $\begin{array}{l}\text { PERCENT } \\
\text { SODIUM }\end{array}$ & $\begin{array}{l}\text { POTAS- } \\
\text { SIUM, } \\
\text { DIS- } \\
\text { SOLVED } \\
\text { (MG/L } \\
\text { AS K) }\end{array}$ & $\begin{array}{l}\text { CHLO- } \\
\text { RIDE, } \\
\text { DIS- } \\
\text { SOLVED } \\
\text { (MG/L } \\
\text { AS CL) }\end{array}$ & $\begin{array}{l}\text { SULFATE } \\
\text { DIS- } \\
\text { SOLVED } \\
\text { (MG/L } \\
\text { AS S04) }\end{array}$ & $\begin{array}{l}\text { FLUO- } \\
\text { RIDE, } \\
\text { DIS- } \\
\text { SOLVED } \\
\text { (MG/L } \\
\text { AS F) }\end{array}$ & $\begin{array}{l}\text { SILICA, } \\
\text { DIS- } \\
\text { SOLVED } \\
\text { (MG/L } \\
\text { AS } \\
\text { SIO2) }\end{array}$ & $\begin{array}{c}\text { ARSENIC } \\
\text { DIS- } \\
\text { SOLVED } \\
(\mu \mathrm{G} / \mathrm{L} \\
\text { AS AS) }\end{array}$ \\
\hline \multicolumn{13}{|l|}{ MAR } \\
\hline $11---$ & $-\quad 2,500$ & 600 & 300 & 120 & 1 & 9 & 53 & 32 & 2,400 & .30 & 10 & 2 \\
\hline $11---$ & $-2,500$ & 610 & 300 & 120 & 1 & 8 & 47 & 32 & 2,500 & .30 & 10 & 1 \\
\hline $20---$ & $-\quad 2,700$ & 570 & 370 & 83 & .7 & 6 & 21 & 25 & 2,300 & .30 & 89 & 1 \\
\hline \multicolumn{13}{|l|}{ APR } \\
\hline $01--$ & $-\quad 2,900$ & 580 & 420 & 54 & .4 & 4 & 14 & 3.7 & 2,500 & .20 & 7.0 & 1 \\
\hline $15---$ & $-2,800$ & 530 & 390 & 55 & .4 & 4 & 20 & 7.4 & 2,500 & .40 & 8.4 & $<1$ \\
\hline MAY & $-2,900$ & 560 & 400 & 54 & .4 & 4 & 23 & 7.4 & 2,600 & .40 & 9.7 & 1 \\
\hline $23--$ & -- & 500 & -- & 62 & -- & 3 & 23 & 5.6 & 2,400 & .40 & 8.9 & 1 \\
\hline $30---$ & $-\quad 2,700$ & 500 & 380 & 60 & .5 & 4 & 24 & 5.7 & 2,600 & .40 & 9.2 & $<1$ \\
\hline \multicolumn{13}{|c|}{ JN } \\
\hline 07--- & $-2,400$ & 420 & 360 & 380 & 3 & 24 & 28 & 5.6 & 2,500 & -- & 11 & $<1$ \\
\hline $28--$ & $-2,300$ & 410 & 340 & 62 & .5 & 5 & 38 & 2.8 & 2,000 & .50 & 15 & $<1$ \\
\hline JUL & - & $\cdots$ & - & -- & $\cdots$ & $\cdots$ & -- & $\cdots$ & $\ldots$ & $\ldots$ & -- & -- \\
\hline $20--$ & $-\quad 2,500$ & 420 & 380 & 65 & .6 & 5 & 47 & 5.5 & 2,500 & .40 & 23 & 2 \\
\hline
\end{tabular}


Table 4.--Water-quality data from Lysimeter 1--Continued

WATER QUALITY DATA, WATER YEAR OCTOBER 1977 TO SEPTEMBER 1978--Continued

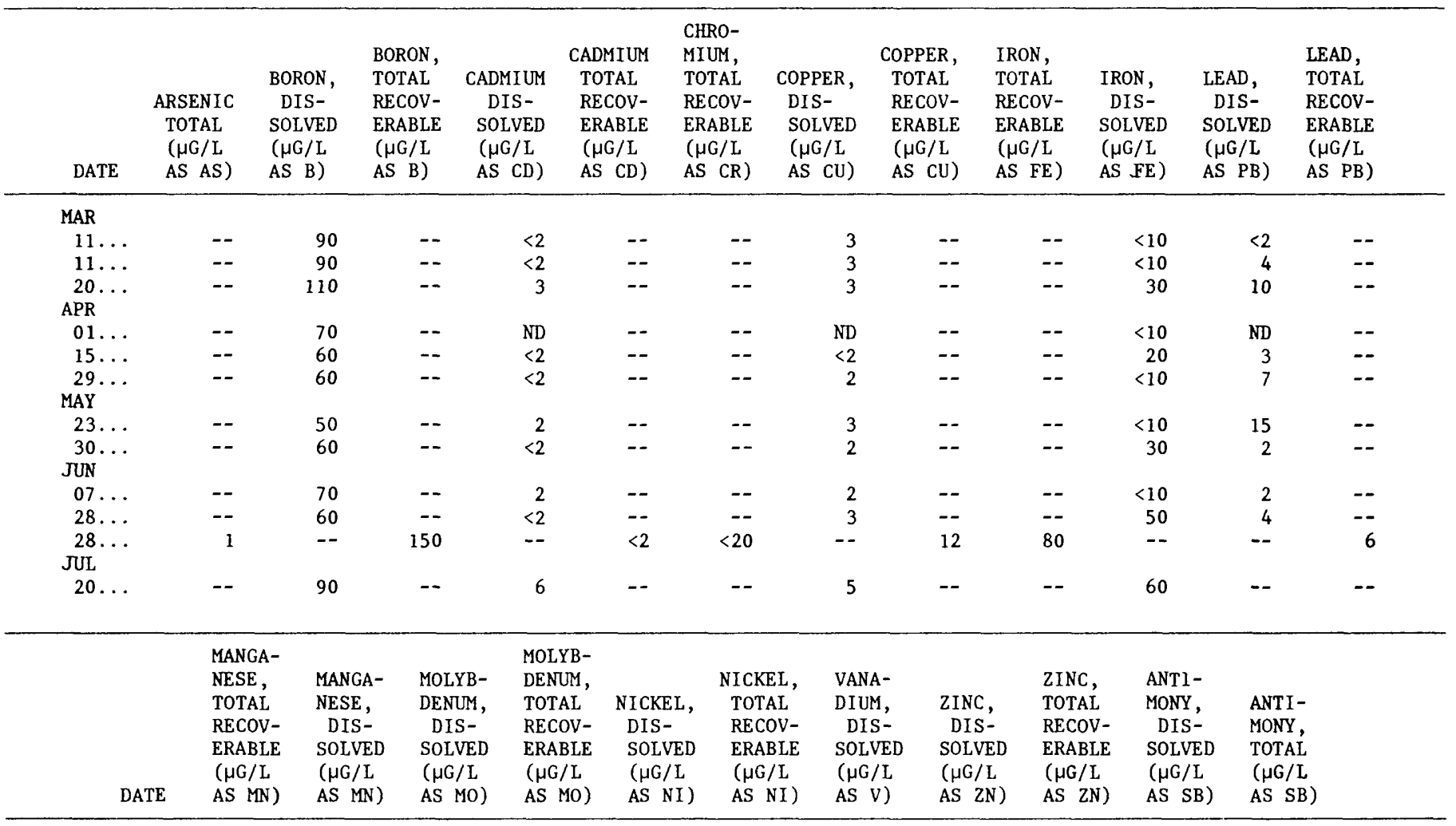

MAR

\begin{tabular}{|c|c|c|c|c|c|c|c|c|c|c|c|}
\hline MAR & & & & & & & & & & & \\
\hline $11 \ldots$ & -- & 30 & 2 & -- & 7 & -- & 0 & 20 & -- & -- & - \\
\hline $11 \ldots$ & -- & 20 & 3 & -- & 4 & - & 0 & 20 & -- & -- & -- \\
\hline $20 \ldots$ & -- & 40 & 4 & -- & $<2$ & -- & 0 & 30 & -- & $<1$ & - \\
\hline APR & & & & & & & & & & & \\
\hline $01 \ldots$ & -- & 20 & 5 & -- & 5 & -- & 0 & $<20$ & -- & $<1$ & -- \\
\hline $15 \ldots$ & -- & $<10$ & 4 & -- & 5 & -- & 0 & 20 & -- & 1 & -- \\
\hline$\underset{\text { MAY }}{29} \ldots$ & -- & 20 & 2 & -- & ND & -- & 0 & 20 & -- & $<1$ & -- \\
\hline $23 \ldots$ & -- & 20 & 4 & -- & ND & -- & 0 & 20 & -- & 1 & -- \\
\hline $30 \ldots$ & -- & 20 & 4 & -- & 4 & -- & 0 & 20 & -- & $<1$ & -- \\
\hline JUN & & & & & & & & & & & \\
\hline $07 \ldots$ & -- & $<10$ & 4 & -- & 4 & $\cdots$ & 0 & 20 & -- & $<1$ & -- \\
\hline $28 \ldots$ & -- & 20 & 4 & -- & 5 & -- & 0 & 30 & -- & 3 & -- \\
\hline $28 \ldots$ & 20 & -- & -- & 7 & -- & 8 & -- & -- & 20 & -- & $<1$ \\
\hline ЛL & & & & & & & & & & & \\
\hline $20 \ldots$ & -- & $<10$ & 5 & -- & 8 & -- & -- & -- & -- & -- & -- \\
\hline
\end{tabular}


Table 4.--Water-quality data from Lysimeter 1--Continued

WATER QUALITY DATA, WATER YEAR OCTOBER 1977 TO SEPTEMBER 1978--Continued

\begin{tabular}{|c|c|c|c|c|c|c|c|c|c|c|}
\hline DATE & $\begin{array}{l}\text { ALUM- } \\
\text { INUM, } \\
\text { TOTAL } \\
\text { RECOV- } \\
\text { ERABLE } \\
(\mu G / L \\
\text { AS AL) }\end{array}$ & $\begin{array}{l}\text { ALUM- } \\
\text { INUM, } \\
\text { DIS- } \\
\text { SOLVED } \\
(\mu G / L \\
\text { AS AL) }\end{array}$ & $\begin{array}{l}\text { SELE- } \\
\text { NIUM, } \\
\text { DIS- } \\
\text { SOLVED } \\
(\mu G / L \\
\text { AS SE) }\end{array}$ & $\begin{array}{l}\text { SELE- } \\
\text { NIUM, } \\
\text { TOTAL } \\
(\mu G / L \\
\text { AS SE) }\end{array}$ & $\begin{array}{l}\text { SOLIDS, } \\
\text { SUM OF } \\
\text { CONSTI- } \\
\text { TUENTS, } \\
\text { DIS- } \\
\text { SOLVED } \\
\text { (MG/L) }\end{array}$ & $\begin{array}{c}\text { SOLIDS, } \\
\text { DIS- } \\
\text { SOLVED } \\
\text { (TONS } \\
\text { PER } \\
\text { AC-FT) }\end{array}$ & $\begin{array}{c}\text { MERCURY } \\
\text { DIS- } \\
\text { SOLVED } \\
(\mu G / L \\
\text { AS HG) }\end{array}$ & $\begin{array}{c}\text { MERCURY } \\
\text { TOTAL } \\
\text { RECOV- } \\
\text { ERABLE } \\
(\mu G / L \\
\text { AS HG) }\end{array}$ & $\begin{array}{l}\text { ALKA- } \\
\text { LINITY } \\
\text { LAB } \\
\text { (MG/L } \\
\text { AS } \\
\text { CACO3) }\end{array}$ & $\begin{array}{l}\text { BICAR- } \\
\text { BONATE } \\
\text { IT-LAB } \\
\text { (MG/L AS } \\
\text { HCO3) }\end{array}$ \\
\hline \multicolumn{11}{|l|}{ MAR } \\
\hline $11 \ldots$ & -- & $<100$ & 290 & -- & 4000 & 5.5 & $<.1$ & -- & 210 & 260 \\
\hline $11 \ldots$ & -- & $<100$ & 290 & -- & 4100 & 5.6 & $<.1$ & -- & 210 & 260 \\
\hline $20 \ldots$ & -- & 20 & 100 & -- & 4000 & 5.5 & $<.1$ & -- & 210 & 260 \\
\hline \multicolumn{11}{|l|}{ APR } \\
\hline $01 \ldots$ & -- & $<100$ & 380 & -- & 4000 & 5.5 & $<.1$ & -- & 250 & 310 \\
\hline $15 \ldots$ & -- & $<100$ & 270 & -- & 3800 & 5.1 & $<.1$ & -- & 170 & 210 \\
\hline \multicolumn{11}{|l|}{ MAY } \\
\hline $23 \ldots$ & -- & $<100$ & $<1$ & -- & -- & -- & $<.1$ & -- & 160 & 190 \\
\hline $30 \ldots$ & -- & $<100$ & 230 & -- & 3800 & 5.1 & $<.1$ & -- & 120 & 150 \\
\hline \multicolumn{11}{|l|}{ JUN } \\
\hline $07 \ldots$ & -- & $<100$ & 190 & -- & 3900 & 5.3 & $<.1$ & -- & 110 & 140 \\
\hline $28 \ldots$ & -- & $<100$ & 170 & -- & 3100 & 4.2 & $<.1$ & -- & 120 & 150 \\
\hline $28 \ldots$ & 30 & -- & -- & 190 & -- & -- & -- & $<.1$ & -- & -- \\
\hline \multicolumn{11}{|l|}{ JUL } \\
\hline $20 \ldots$ & -- & 10 & 290 & -- & 3600 & 4.9 & $<.1$ & -- & 120 & 150 \\
\hline
\end{tabular}

WATER QUALITY DATA, WATER YEAR OCTOBER 1978 TO SEPTEMBER 1979

\begin{tabular}{|c|c|c|c|c|c|c|c|c|c|}
\hline DATE & $\begin{array}{l}\text { TEMPER- } \\
\text { ATURE } \\
\left({ }^{\circ} \mathrm{C}\right)\end{array}$ & $\begin{array}{l}\text { SPE- } \\
\text { CIFIC } \\
\text { CON- } \\
\text { DUCT- } \\
\text { ANCE } \\
(\mu S / C M)\end{array}$ & $\begin{array}{l}\text { OXYGEN, } \\
\text { DIS- } \\
\text { SOLVED } \\
\text { (MG/L) }\end{array}$ & $\begin{array}{c}\text { PH } \\
\text { (STAND- } \\
\text { ARD } \\
\text { UNITS) }\end{array}$ & $\begin{array}{c}\text { CARBON } \\
\text { DIOXIDE } \\
\text { DIS- } \\
\text { SOLVED } \\
\text { (MG/L } \\
\text { AS CO2) }\end{array}$ & $\begin{array}{c}\text { CAR- } \\
\text { BONATE } \\
\text { FET - FLD } \\
\text { (MG/L } \\
\text { AS CO3) }\end{array}$ & $\begin{array}{c}\text { NITRO- } \\
\text { GEN, } \\
\text { NO2+NO3 } \\
\text { DIS- } \\
\text { SOLVED } \\
\text { (MG/L } \\
\text { AS N) }\end{array}$ & $\begin{array}{l}\text { PHOS- } \\
\text { PHATE, } \\
\text { ORTHO, } \\
\text { DIS- } \\
\text { SOLVED } \\
\text { (MG/L } \\
\text { AS PO4) }\end{array}$ & $\begin{array}{l}\text { PHOS- } \\
\text { PHORUS, } \\
\text { ORTHO, } \\
\text { DIS- } \\
\text { SOLVED } \\
\text { (MG/L } \\
\text { AS P) }\end{array}$ \\
\hline \multicolumn{10}{|l|}{ MAR } \\
\hline $01 \ldots$ & 24.0 & 4170 & 6.8 & 7.7 & 6.8 & 0 & 30 & .09 & .030 \\
\hline \multicolumn{10}{|l|}{ APR } \\
\hline $06 \ldots$ & 8.0 & 4050 & 8.4 & 7.8 & 5.8 & 0 & 16 & .00 & $<.010$ \\
\hline \multicolumn{10}{|l|}{ MAY } \\
\hline $10 \ldots$ & 8.5 & 3820 & 13.6 & 7.9 & 8.3 & 0 & 14 & .03 & .010 \\
\hline \multicolumn{10}{|l|}{ JUN } \\
\hline$\underset{\text { JUL }}{16 \ldots}$ & \multicolumn{7}{|c|}{ JUL } & .00 & $<.010$ \\
\hline $27 \ldots$ & 20.0 & 3400 & 6.6 & 8.1 & 1.7 & 0 & 16 & .00 & $<.010$ \\
\hline
\end{tabular}


Table 4.--Water-quality data from Lysimeter 1--Continued

WATER QUALITY DATA, WATER YEAR OCTOBER 1978 TO SEPTEMBER 1979--Continued

\begin{tabular}{|c|c|c|c|c|c|c|c|c|c|c|c|}
\hline DATE & $\begin{array}{l}\text { HARD- } \\
\text { NESS } \\
\text { (MG/L } \\
\text { AS } \\
\text { CACO3) }\end{array}$ & $\begin{array}{c}\text { HARD- } \\
\text { NESS, } \\
\text { NONCAR- } \\
\text { BONATE } \\
\text { (MG/L AS } \\
\text { CACO3) }\end{array}$ & $\begin{array}{l}\text { CALCIUM } \\
\text { DIS- } \\
\text { SOLVED } \\
\text { (MG/L } \\
\text { AS CA) }\end{array}$ & $\begin{array}{l}\text { MAGNE- } \\
\text { SIUM, } \\
\text { DIS- } \\
\text { SOLVED } \\
\text { (MG/L } \\
\text { AS MG) }\end{array}$ & $\begin{array}{l}\text { SODIUM, } \\
\text { DIS- } \\
\text { SOLVED } \\
\text { (MG/L } \\
\text { AS NA) }\end{array}$ & $\begin{array}{l}\text { SODIUM } \\
\text { AD- } \\
\text { SORP- } \\
\text { TION } \\
\text { RATIO }\end{array}$ & $\begin{array}{r}\text { PERCENT } \\
\text { SODIUM }\end{array}$ & $\begin{array}{c}\text { SODIUM+ } \\
\text { POTAS- } \\
\text { SIUM } \\
\text { DIS- } \\
\text { SOLVED } \\
\text { (MG/L } \\
\text { AS NA) }\end{array}$ & $\begin{array}{l}\text { POTAS- } \\
\text { SIUM, } \\
\text { DIS- } \\
\text { SOLVED } \\
\text { (MG/L } \\
\text { AS K) }\end{array}$ & $\begin{array}{l}\text { CHLO- } \\
\text { RIDE, } \\
\text { DIS- } \\
\text { SOLVED } \\
\text { (MG/L } \\
\text { AS CL) }\end{array}$ & $\begin{array}{l}\text { SULFATE } \\
\text { DIS- } \\
\text { SOLVED } \\
\text { (MG/L } \\
\text { AS S04) }\end{array}$ \\
\hline \multicolumn{12}{|l|}{ MAR } \\
\hline $01 \ldots$ & 2800 & 2600 & 420 & 420 & 60 & .5 & 4 & -- & 19 & 5.4 & 2800 \\
\hline \multicolumn{12}{|l|}{ APR } \\
\hline $06 \ldots$ & 2700 & 2500 & 360 & 430 & 46 & .4 & 4 & -- & 16 & 1.4 & 2600 \\
\hline $27 \ldots$ & 2700 & 2600 & 420 & 400 & 47 & .4 & 4 & -- & 20 & 1.4 & 2600 \\
\hline \multicolumn{12}{|l|}{ MAY } \\
\hline $10 \ldots$ & 1100 & 800 & 330 & 75 & 66 & .9 & 11 & 110 & 44 & 1.9 & 2500 \\
\hline \multicolumn{12}{|l|}{ JUN } \\
\hline $16 \ldots$ & 2700 & 2600 & 450 & 390 & 59 & .5 & 4 & 95 & 36 & 1.8 & 2800 \\
\hline $27 \ldots$ & 2700 & 2600 & 440 & 380 & 59 & .5 & 10 & 100 & 42 & 2.0 & 2400 \\
\hline DATE & $\begin{array}{l}\text { FLUO- } \\
\text { RIDE, } \\
\text { DIS- } \\
\text { SOLVED } \\
\text { (MG/L } \\
\text { AS F) }\end{array}$ & $\begin{array}{l}\text { SILICA, } \\
\text { DIS- } \\
\text { SOLVED } \\
\text { (MG/L } \\
\text { AS } \\
\text { SIO2) }\end{array}$ & $\begin{array}{c}\text { ARSENIC } \\
\text { DIS- } \\
\text { SOLVED } \\
(\mu \mathrm{G} / \mathrm{L} \\
\text { AS AS) }\end{array}$ & $\begin{array}{c}\text { ARSENIC } \\
\text { TOTAL } \\
\text { ( } \mu \mathrm{G} / \mathrm{L} \\
\text { AS AS) }\end{array}$ & $\begin{array}{l}\text { BORON, } \\
\text { DIS- } \\
\text { SOLVED } \\
(\mu G / L \\
\text { AS B) }\end{array}$ & $\begin{array}{c}\text { CADMIUM } \\
\text { DIS- } \\
\text { SOLVED } \\
(\mu \mathrm{G} / \mathrm{L} \\
\text { AS CD) }\end{array}$ & $\begin{array}{l}\text { CADMIUM } \\
\text { SUS- } \\
\text { PENDED } \\
\text { RECOV- } \\
\text { ERABLE } \\
(\mu G / L \\
\text { AS CD) }\end{array}$ & $\begin{array}{l}\text { CADMIUM } \\
\text { TOTAL } \\
\text { RECOV- } \\
\text { ERABLE } \\
(\mu \mathrm{G} / \mathrm{L} \\
\text { AS CD) }\end{array}$ & $\begin{array}{l}\text { COPPER, } \\
\text { DIS- } \\
\text { SOLVED } \\
\text { ( } \mu \mathrm{G} / \mathrm{L} \\
\text { AS CU) }\end{array}$ & $\begin{array}{l}\text { COPPER, } \\
\text { SUS- } \\
\text { PENDED } \\
\text { RECOV- } \\
\text { ERABLE } \\
(\mu \mathrm{G} / \mathrm{L} \\
\text { AS CU) }\end{array}$ & $\begin{array}{c}\text { COPPER, } \\
\text { TOTAL } \\
\text { RECOV- } \\
\text { ERABLE } \\
\text { ( } \mu \mathrm{G} / \mathrm{L} \\
\text { AS CU) }\end{array}$ \\
\hline
\end{tabular}

MAR

$\begin{array}{rrrrr}.1 & & & \\ 01 \ldots & .30 & 10 & 1 & 1\end{array}$

23..

APR

06... $\quad .40$

$27 \ldots \quad .40$

MAY

$10 \ldots . \quad .40$

$25 \ldots \quad .50$

JN

$16 \ldots . .50$

JUL

27 ...
6.9

7.7

8.7

7.8

9.5

18

70
60
50

2
ND
ND
ND
ND
ND
ND
$<2$

$\begin{aligned} 0 & \\ 0 & \\ 2 & \\ 1 & \\ 2 & \\ 12 & \\ 0 & \\ 0 & \end{aligned}$

$\begin{array}{rrrr}<2 & 3 & 1 & 4 \\ \text { ND } & <2 & 0 & \text { ND } \\ 2 & <2 & 3 & 4 \\ <2 & <2 & 1 & 2 \\ 2 & \text { ND } & 2 & 2 \\ 12 & \text { ND } & 5 & 5 \\ \text { ND } & <2 & 5 & 6 \\ \text { ND } & 2 & 1 & 3\end{array}$


Table 4.--Water-quality data from Lysimeter 1--Continued

WATER QUALITY DATA, WATER YEAR OCTOBER 1978 TO SEPTEMBER 1979--Continued

\begin{tabular}{|c|c|c|c|c|c|c|c|c|c|c|c|}
\hline DATE & $\begin{array}{c}\text { IRON, } \\
\text { SUS- } \\
\text { PENDED } \\
\text { RECOV- } \\
\text { ERABLE } \\
(\mu G / L \\
\text { AS FE) }\end{array}$ & $\begin{array}{l}\text { IRON, } \\
\text { TOTAL } \\
\text { RECOV- } \\
\text { ERABLE } \\
(\mu G / L \\
\text { AS FE) }\end{array}$ & $\begin{array}{l}\text { IRON, } \\
\text { DIS- } \\
\text { SOLVED } \\
(\mu G / L \\
\text { AS FE) }\end{array}$ & $\begin{array}{l}\text { LEAD, } \\
\text { DIS- } \\
\text { SOLVED } \\
(\mu G / L \\
\text { AS PB) }\end{array}$ & $\begin{array}{l}\text { LEAD, } \\
\text { SUS- } \\
\text { PENDED } \\
\text { RECOV- } \\
\text { ERABLE } \\
(\mu G / L \\
\text { AS PB) }\end{array}$ & $\begin{array}{l}\text { LEAD, } \\
\text { TOTAL } \\
\text { RECOV- } \\
\text { ERABLE } \\
(\mu \mathrm{G} / \mathrm{L} \\
\text { AS PB) }\end{array}$ & $\begin{array}{l}\text { MANGA- } \\
\text { NESE, } \\
\text { SUS- } \\
\text { PENDED } \\
\text { RECOV. } \\
(\mu G / L \\
\text { AS MN) }\end{array}$ & $\begin{array}{l}\text { MANGA- } \\
\text { NESE, } \\
\text { TOTAL } \\
\text { RECOV- } \\
\text { ERABLE } \\
(\mu G / L \\
\text { AS MN) }\end{array}$ & $\begin{array}{l}\text { MANGA- } \\
\text { NESE , } \\
\text { DIS- } \\
\text { SOLVED } \\
(\mu G / L \\
\text { AS MN })\end{array}$ & $\begin{array}{l}\text { MOLYB- } \\
\text { DENUM, } \\
\text { DIS- } \\
\text { SOLVED } \\
(\mu \mathrm{G} / \mathrm{L} \\
\text { AS MO) }\end{array}$ & $\begin{array}{l}\text { MOLYB- } \\
\text { DENUM, } \\
\text { SUS- } \\
\text { PENDED } \\
\text { RECOV. } \\
(\mu G / L \\
\text { AS MO) }\end{array}$ \\
\hline
\end{tabular}

MAR

\begin{tabular}{|c|c|c|c|c|c|c|c|c|c|c|c|}
\hline $\begin{array}{l}01 \ldots \\
23 \ldots \\
\text { APR }\end{array}$ & $\begin{array}{l}10 \\
20\end{array}$ & $\begin{array}{l}60 \\
50\end{array}$ & $\begin{array}{l}50 \\
30\end{array}$ & $\begin{array}{r}<2 \\
3\end{array}$ & $\begin{array}{r}0 \\
10\end{array}$ & $\begin{array}{l}<2 \\
13\end{array}$ & $\begin{array}{r}10 \\
0\end{array}$ & $\begin{array}{l}20 \\
20\end{array}$ & $\begin{array}{r}<10 \\
20\end{array}$ & $\begin{array}{l}5 \\
4\end{array}$ & $\begin{array}{l}0 \\
1\end{array}$ \\
\hline $06 \ldots$ & 10 & 70 & 60 & ND & 11 & 11 & 0 & 20 & 20 & 3 & 3 \\
\hline $\begin{array}{r}27 \ldots \\
\text { MAY }\end{array}$ & 0 & 30 & 30 & ND & 110 & 110 & 0 & $<10$ & $<10$ & 3 & 3 \\
\hline $10 \ldots$ & 0 & 20 & 30 & ND & 37 & 37 & 0 & 20 & 20 & 3 & 2 \\
\hline $\begin{array}{l}25 \ldots \\
\text { JUN }\end{array}$ & 20 & 40 & 20 & ND & 7 & 7 & 0 & 20 & 20 & $<1$ & 5 \\
\hline$\frac{16 \ldots}{\text { ЛUL }}$ & -- & -- & 20 & ND & 7 & 7 & -- & -- & 20 & 2 & 1 \\
\hline $27 \ldots$ & 50 & 70 & 20 & $\mathrm{ND}$ & 15 & 15 & 0 & 20 & 20 & 4 & 0 \\
\hline DATE & $\begin{array}{l}\text { MOLYB- } \\
\text { DENUM, } \\
\text { TOTAL } \\
\text { RECOV- } \\
\text { ERABLE } \\
(\mu \mathrm{G} / \mathrm{L} \\
\text { AS MO) }\end{array}$ & $\begin{array}{l}\text { NICKEL, } \\
\text { DIS- } \\
\text { SOLVED } \\
(\mu \mathrm{G} / \mathrm{L} \\
\text { AS NI) }\end{array}$ & $\begin{array}{c}\text { NICKEL, } \\
\text { SUS- } \\
\text { PENDED } \\
\text { RECOV- } \\
\text { ERABLE } \\
(\mu G / L \\
\text { AS NI) }\end{array}$ & $\begin{array}{l}\text { NICKEL, } \\
\text { TOTAL } \\
\text { RECOV- } \\
\text { ERABLE } \\
(\mu \mathrm{G} / \mathrm{L} \\
\text { AS NI) }\end{array}$ & $\begin{array}{l}\text { VANA- } \\
\text { DIUM, } \\
\text { DIS- } \\
\text { SOLVED } \\
(\mu G / L \\
\text { AS V) }\end{array}$ & $\begin{array}{l}\text { ZINC, } \\
\text { DIS- } \\
\text { SOLVED } \\
(\mu \mathrm{G} / \mathrm{L} \\
\text { AS ZN) }\end{array}$ & $\begin{array}{l}\text { ZINC, } \\
\text { SUS- } \\
\text { PENDED } \\
\text { RECOV- } \\
\text { ERABLE } \\
(\mu G / L \\
\text { AS ZN) }\end{array}$ & $\begin{array}{l}\text { ZINC, } \\
\text { TOTAL } \\
\text { RECOV- } \\
\text { ERABLE } \\
(\mu \mathrm{G} / \mathrm{L} \\
\text { AS ZN) }\end{array}$ & $\begin{array}{l}\text { ALUM- } \\
\text { INUM, } \\
\text { TOTAL } \\
\text { RECOV- } \\
\text { ERABLE } \\
(\mu \mathrm{G} / \mathrm{L} \\
\text { AS AL) }\end{array}$ & $\begin{array}{l}\text { ALUM- } \\
\text { INUM, } \\
\text { DIS- } \\
\text { SOLVED } \\
\text { ( } \mu G / L \\
\text { AS AL) }\end{array}$ & $\begin{array}{l}\text { ALUM- } \\
\text { INUM, } \\
\text { SUS- } \\
\text { PENDED } \\
\text { RECOV. } \\
(\mu G / L \\
\text { AS AL) }\end{array}$ \\
\hline
\end{tabular}

\begin{tabular}{|c|c|c|c|c|c|c|c|c|c|c|c|}
\hline & & & & & & & & & & & \\
\hline $01 \ldots$ & 3 & 4 & 1 & 5 & 0 & 40 & 0 & 40 & 30 & $<100$ & 30 \\
\hline $23 \ldots$ & 5 & 3 & 2 & 5 & 0 & 20 & 10 & 30 & 20 & $<100$ & 20 \\
\hline \multicolumn{12}{|l|}{ APR } \\
\hline $06 \ldots$ & 6 & 4 & 3 & 7 & 0 & 30 & 0 & 30 & 60 & $<100$ & 60 \\
\hline $27 \ldots$ & 6 & ND & 3 & 3 & 0 & 30 & 10 & 40 & 40 & $<100$ & 40 \\
\hline \multicolumn{12}{|l|}{ MAY } \\
\hline $10 \ldots$ & 5 & ND & 4 & 4 & 0 & 30 & 10 & 40 & 70 & 20 & 50 \\
\hline $25 \ldots$ & 5 & ND & 0 & ND & 0 & 20 & 0 & 20 & 110 & $<100$ & 110 \\
\hline \multicolumn{12}{|l|}{ JUN } \\
\hline $16 .$. & 3 & $<2$ & 6 & 7 & 0 & 30 & 10 & 40 & 120 & $<100$ & 120 \\
\hline \multicolumn{12}{|l|}{ JUL } \\
\hline $27 \ldots$ & 4 & 2 & 3 & 5 & $<1$ & 20 & 10 & 30 & 110 & $<100$ & 110 \\
\hline
\end{tabular}


Table 4.--Water-quality data from Lysimeter 1--Continued

WATER QUALITY DATA, WATER YEAR OCTOBER 1978 TO SEPTEMBER 1979--Continued

\begin{tabular}{|c|c|c|c|c|c|c|c|c|c|c|}
\hline DATE & $\begin{array}{l}\text { SELE- } \\
\text { NIUM, } \\
\text { DIS- } \\
\text { SOLVED } \\
(\mu G / L \\
\text { AS SE) }\end{array}$ & $\begin{array}{l}\text { SELE- } \\
\text { NIUM, } \\
\text { SUS- } \\
\text { PENDED } \\
\text { TOTAL } \\
(\mu \mathrm{G} / \mathrm{L} \\
\text { AS SE) }\end{array}$ & $\begin{array}{l}\text { SELE- } \\
\text { NIUM, } \\
\text { TOTAL } \\
(\mu G / L \\
\text { AS SE })\end{array}$ & $\begin{array}{l}\text { SOLIDS, } \\
\text { SUM OF } \\
\text { CONSTI- } \\
\text { TUENTS, } \\
\text { DIS- } \\
\text { SOLVED } \\
(\mathrm{MG} / \mathrm{L})\end{array}$ & $\begin{array}{c}\text { SOLIDS, } \\
\text { DIS- } \\
\text { SOLVED } \\
\text { (TONS } \\
\text { PER } \\
\text { AC-FT) }\end{array}$ & $\begin{array}{c}\text { MERCURY } \\
\text { DIS - } \\
\text { SOLVED } \\
(\mu G / L \\
\text { AS HG) }\end{array}$ & $\begin{array}{c}\text { MERCURY } \\
\text { SUS- } \\
\text { PENDED } \\
\text { RECOV- } \\
\text { ERABLE } \\
(\mu G / L \\
\text { AS HG) }\end{array}$ & $\begin{array}{l}\text { MERCURY } \\
\text { TOTAL } \\
\text { RECOV- } \\
\text { ERABLE } \\
(\mu G / L \\
\text { AS HG) }\end{array}$ & $\begin{array}{l}\text { ALKA- } \\
\text { LINITY } \\
\text { LAB } \\
\text { (MG/L } \\
\text { AS } \\
\text { CACO3) }\end{array}$ & $\begin{array}{c}\text { BICAR- } \\
\text { BONATE } \\
\text { IT-LAB } \\
\text { (MG/L AS } \\
\text { HCO3) }\end{array}$ \\
\hline \multicolumn{11}{|l|}{ MAR } \\
\hline $01 \ldots$ & 230 & 0 & 230 & 4000 & 5.4 & $<.1$ & .3 & .3 & 160 & 190 \\
\hline $\begin{array}{l}23 \ldots \\
\text { APR }\end{array}$ & 180 & 20 & 200 & 3800 & 5.1 & $<.1$ & .0 & $<.1$ & 210 & 250 \\
\hline $06 \ldots$ & 120 & 20 & 140 & 3700 & 5.0 & $<.1$ & .0 & $<.1$ & 190 & 230 \\
\hline$\underset{M A Y}{27 \ldots}$ & 150 & 0 & 150 & 3700 & 5.0 & $<.1$ & .1 & $<.1$ & 130 & 160 \\
\hline $10 \ldots$ & 82 & 28 & 110 & 3300 & 4.5 & $<.1$ & .2 & .2 & 340 & 410 \\
\hline$\underset{\text { JN }}{25 \ldots}$ & 120 & 0 & 110 & 3400 & 4.6 & $<.1$ & .2 & .2 & 120 & 150 \\
\hline$\underset{\text { JUL }}{16 \ldots}$ & 120 & 10 & 130 & 3900 & 5.3 & $<.1$ & .0 & $<.1$ & 120 & 150 \\
\hline $27 \ldots$ & 97 & 3 & 100 & 3500 & 4.7 & $<.1$ & .0 & $<.1$ & 110 & 130 \\
\hline
\end{tabular}

WATER QUALITY DATA, WATER YEAR OCTOBER 1979 TO SEPTEMBER 1980

\begin{tabular}{|c|c|c|c|c|c|c|c|c|c|c|}
\hline DATE & $\begin{array}{l}\text { TEMPER- } \\
\text { ATURE } \\
\left({ }^{\circ} \mathrm{C}\right)\end{array}$ & $\begin{array}{c}\text { SPE- } \\
\text { CIFIC } \\
\text { CON- } \\
\text { DUCT- } \\
\text { ANCE } \\
(\mu S / C M)\end{array}$ & $\begin{array}{c}\text { OXYGEN, } \\
\text { DIS - } \\
\text { SOLVED } \\
(\mathrm{MG} / \mathrm{L})\end{array}$ & $\begin{array}{c}\text { PH } \\
\text { (STAND- } \\
\text { ARD } \\
\text { UNITS) }\end{array}$ & $\begin{array}{c}\text { CARBON } \\
\text { DIOXIDE } \\
\text { DIS- } \\
\text { SOLVED } \\
(\mathrm{MG} / \mathrm{L} \\
\text { AS CO2) }\end{array}$ & $\begin{array}{c}\text { NITRO- } \\
\text { GEN, } \\
\text { NO2+NO3 } \\
\text { DIS- } \\
\text { SOLVED } \\
\text { (MG/L } \\
\text { AS N) }\end{array}$ & $\begin{array}{c}\text { PHOS- } \\
\text { PHATE, } \\
\text { ORTHO, } \\
\text { DIS- } \\
\text { SOLVED } \\
\text { (MG/L } \\
\text { AS PO4) }\end{array}$ & $\begin{array}{l}\text { PHOS- } \\
\text { PHORUS, } \\
\text { ORTHO, } \\
\text { DIS- } \\
\text { SOLVED } \\
\text { (MG/L } \\
\text { AS P) }\end{array}$ & $\begin{array}{l}\text { HARD- } \\
\text { NESS } \\
(\mathrm{MG} / \mathrm{L} \\
\mathrm{AS} \\
\mathrm{CAC03})\end{array}$ & $\begin{array}{l}\text { HARD- } \\
\text { NESS, } \\
\text { NONCAR- } \\
\text { BONATE } \\
\text { (MG/L AS } \\
\text { CACO3) }\end{array}$ \\
\hline \multicolumn{11}{|l|}{ MAR } \\
\hline $\begin{array}{l}19 \ldots \\
\text { APR }\end{array}$ & 8.0 & 4340 & $-\infty$ & 7.8 & 6.6 & 2.5 & .09 & .030 & 2900 & 2700 \\
\hline $07 \ldots$ & 4.0 & 4040 & 9.3 & 7.3 & 18 & 2.0 & .09 & .030 & 3100 & 2900 \\
\hline $\begin{array}{l}30 \ldots \\
\text { MAY }\end{array}$ & 12.0 & 4070 & 8.5 & 8.4 & 1.3 & 2.3 & .03 & .010 & 2700 & 2500 \\
\hline$\underset{\text { JUN }}{20 \ldots}$ & 11.0 & 3960 & - & 8.6 & 1.2 & 3.2 & .12 & .040 & 2600 & 2400 \\
\hline $\begin{array}{l}05 \ldots \\
26 \ldots\end{array}$ & $\begin{array}{l}16.5 \\
19.5\end{array}$ & $\begin{array}{l}4060 \\
4130\end{array}$ & -- & $\begin{array}{l}8.2 \\
8.4\end{array}$ & $\begin{array}{l}1.6 \\
1.0\end{array}$ & $\begin{array}{l}3.2 \\
3.8\end{array}$ & $\begin{array}{l}.09 \\
.03\end{array}$ & $\begin{array}{l}.030 \\
.010\end{array}$ & $\begin{array}{l}2800 \\
2900\end{array}$ & $\begin{array}{l}2700 \\
2800\end{array}$ \\
\hline
\end{tabular}


Table 4.--Water-quality data from Lysimeter 1--Continued

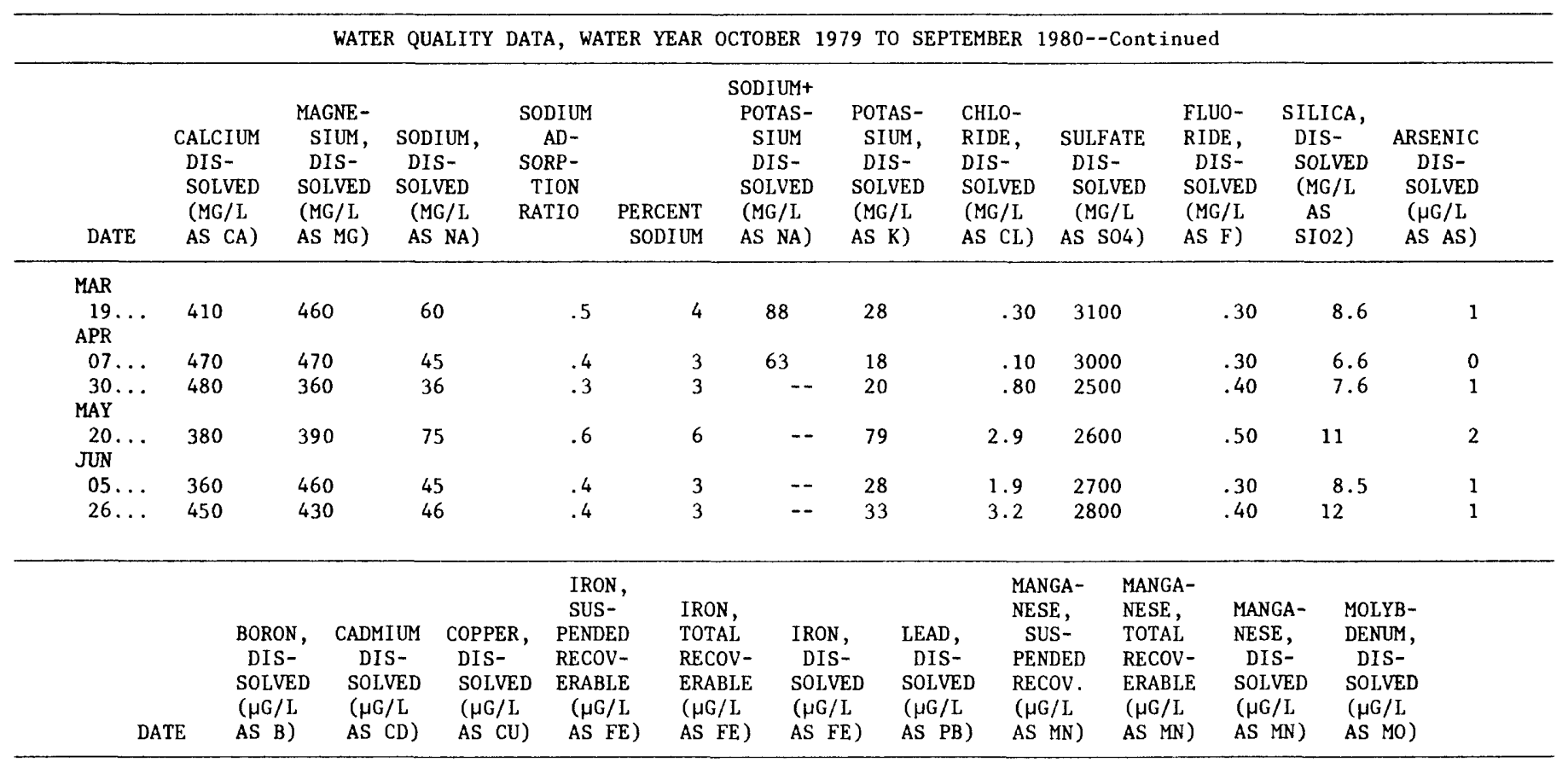

$\begin{aligned} \text { MAR } & \\ 19 \ldots & 70 \\ \text { APR } & \\ 07 \ldots & 60 \\ 30 \ldots & 50 \\ \text { MAY } & \\ 20 \ldots & 80 \\ \text { JUN } & \\ 05 \ldots & 60 \\ 26 \ldots & 90\end{aligned}$

$\begin{array}{rrrrrrrrrr}0 & 2 & 60 & 110 & 50 & 0 & 0 & 10 & 20 & 3 \\ 0 & 2 & 10 & 50 & 40 & 0 & 0 & 20 & 20 & 3 \\ 0 & 1 & 40 & 80 & 40 & 0 & 0 & 10 & 10 & 3 \\ 1 & 5 & 20 & 80 & 60 & 0 & 0 & 10 & 10 & 4 \\ 1 & 7 & 150 & 180 & 30 & 4 & 70 & 80 & 10 & 4 \\ 1 & 4 & 50 & 90 & 40 & 2 & 0 & 20 & 20 & 4\end{array}$


Table 4.--Water-quality data from Lysimeter 1--Continued

WATER QUALITY DATA, WATER YEAR OCTOBER 1979 TO SEPTEMBER 1980--Continued

\begin{tabular}{|c|c|c|c|c|c|c|c|c|c|c|}
\hline & & WATER QU & LITY DAT & , WATER & EAR OCTO & BER 1979 & TO SEPTEMBER & $1980--\mathrm{Co}$ & nued & \\
\hline DATE & $\begin{array}{l}\text { NICKEL, } \\
\text { DIS- } \\
\text { SOLVED } \\
(\mu \mathrm{G} / \mathrm{L} \\
\text { AS NI) }\end{array}$ & $\begin{array}{l}\text { VANA- } \\
\text { DIUM, } \\
\text { DIS- } \\
\text { SOLVED } \\
(\mu G / L \\
\text { AS V) }\end{array}$ & $\begin{array}{l}\text { ZINC, } \\
\text { DIS- } \\
\text { SOLVED } \\
(\mu G / I \\
\text { AS ZN) }\end{array}$ & $\begin{array}{l}\text { ALUM- } \\
\text { INUM, } \\
\text { DIS- } \\
\text { SOLVED } \\
(\mu G / L \\
\text { AS AL) }\end{array}$ & $\begin{array}{l}\text { SELE- } \\
\text { NIUM, } \\
\text { DIS- } \\
\text { SOLVED } \\
(\mu G / L \\
\text { AS SE) }\end{array}$ & $\begin{array}{c}\text { SOLIDS, } \\
\text { SUM OF } \\
\text { CONSTI- } \\
\text { TUENTS, } \\
\text { DIS- } \\
\text { SOLVED } \\
\text { (MG/L) }\end{array}$ & $\begin{array}{c}\text { SOLIDS, } \\
\text { DIS- } \\
\text { SOLVED } \\
\text { (TONS } \\
\text { PER } \\
\text { AC-FT) }\end{array}$ & $\begin{array}{c}\text { MERCURY } \\
\text { DIS- } \\
\text { SOLVED } \\
(\mu G / L \\
\text { AS HG) }\end{array}$ & $\begin{array}{l}\text { ALKA- } \\
\text { LINITY } \\
\text { LAB } \\
\text { (MG/L } \\
\text { AS } \\
\text { CACO3) }\end{array}$ & $\begin{array}{c}\text { BICAR- } \\
\text { BONATE } \\
\text { IT-LAB } \\
\text { (MG/L AS } \\
\text { HCO3) }\end{array}$ \\
\hline \multicolumn{11}{|l|}{ MAR } \\
\hline \multicolumn{11}{|l|}{ APR } \\
\hline $07 \ldots$ & 3 & 1 & 10 & 30 & 110 & 4100 & 5.6 & .0 & 180 & 220 \\
\hline $\begin{array}{l}30 \ldots \\
\text { MAY }\end{array}$ & 4 & 1 & 10 & 20 & 98 & 3500 & 4.8 & .0 & 170 & 207 \\
\hline$\frac{20 \ldots}{J U N}$ & 4 & 3 & 20 & 20 & 97 & 3700 & 5.0 & .0 & 250 & 305 \\
\hline $05 \ldots$ & 5 & 3 & 0 & 20 & 98 & 3700 & 5.0 & .0 & 130 & 159 \\
\hline $26 \ldots$ & 6 & 2 & 20 & 10 & 78 & 3900 & 5.3 & .0 & 130 & 159 \\
\hline
\end{tabular}


Table 5.--Water-quality data from Lysimeter 2

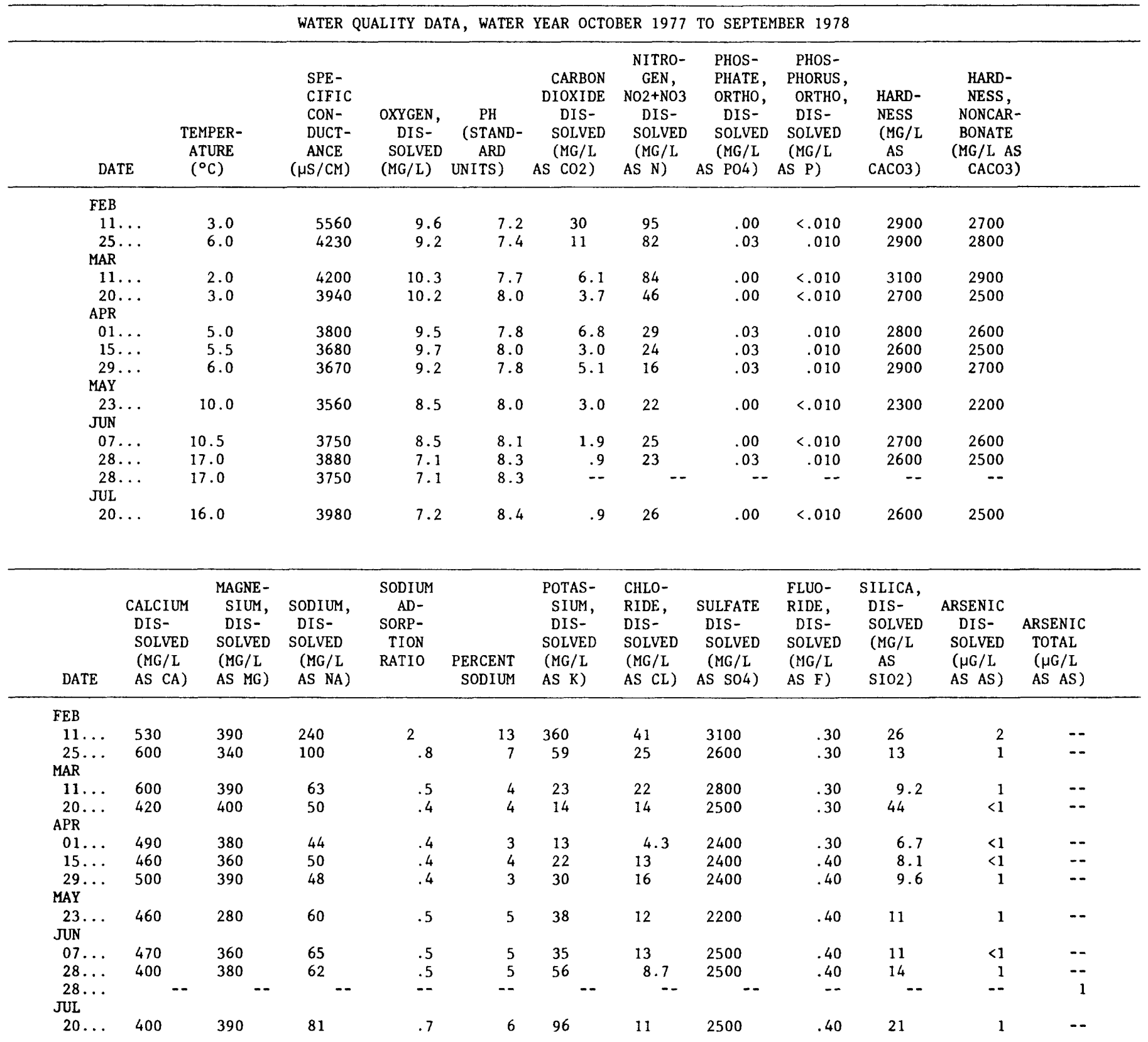


Table 5.--Water-quality data from Lysimeter 2--Continued

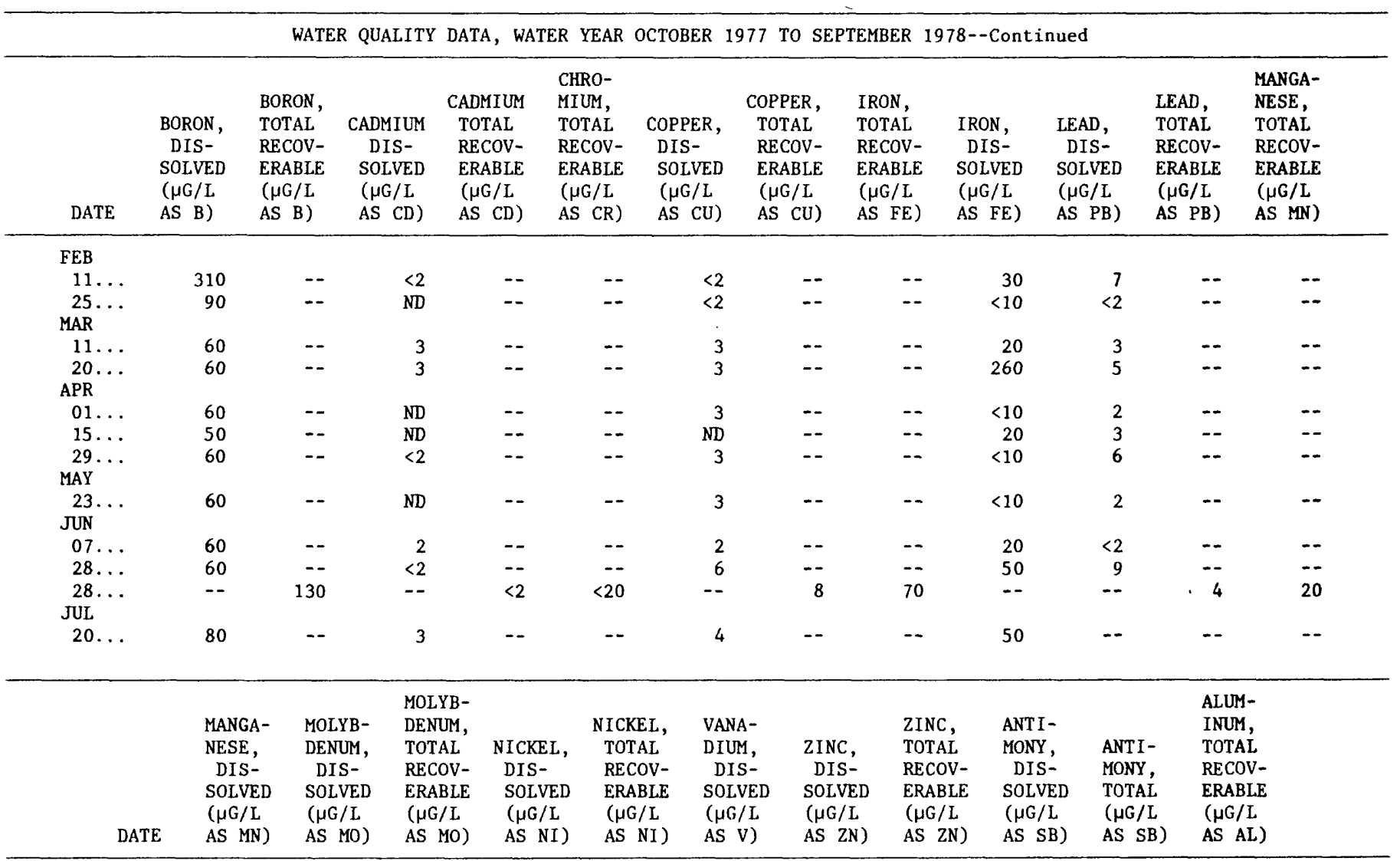

\section{FEB}

\begin{tabular}{|c|c|c|c|c|}
\hline $11 \ldots$ & 20 & 2 & -- & 2 \\
\hline $25 \ldots$ & 20 & 4 & $=-$ & $<2$ \\
\hline \multicolumn{5}{|l|}{ MAR } \\
\hline $11 \ldots$ & 20 & 2 & -- & 11 \\
\hline $20 \ldots$ & 30 & 3 & -- & 2 \\
\hline \multicolumn{5}{|l|}{ APR } \\
\hline $01 \ldots$ & $<10$ & 3 & -- & 3 \\
\hline $15 \ldots$ & $<10$ & 4 & -- & 2 \\
\hline $29 \ldots$ & $<10$ & $<1$ & -- & ND \\
\hline \multicolumn{5}{|l|}{ MAY } \\
\hline $23 \ldots$ & $<10$ & 3 & -- & ND \\
\hline \multicolumn{5}{|l|}{ JUN } \\
\hline $07 \ldots$ & $<10$ & 4 & -- & $<2$ \\
\hline $28 \ldots$ & 20 & 2 & -- & 4 \\
\hline $28 \ldots$ & -- & -- & 7 & -- \\
\hline \multicolumn{5}{|l|}{ JUL } \\
\hline $20 \ldots$ & 20 & 4 & -- & 7 \\
\hline
\end{tabular}

$\begin{array}{lrrrrrr}-- & 1 & 20 & -- & -- & -- & -- \\ -- & 0 & 20 & -- & -- & -- & - \\ -- & 0 & <20 & -- & -- & - & - \\ -- & 0 & 20 & -- & 1 & -- & -- \\ -- & 0 & <20 & -- & <1 & -- & - \\ -- & 0 & <20 & -- & <1 & -- & - \\ -- & 0 & 20 & -- & <1 & -- & - \\ -- & 0 & 20 & -- & 1 & -- & - \\ -- & 0 & 20 & -- & <1 & -- & -- \\ -- & 1 & 20 & -- & 2 & -- & - \\ 8 & -- & -- & 20 & -- & 2 & 20 \\ -- & -- & -- & -- & -- & -- & -\end{array}$


Table 5.--Water-quality data from Lysimeter 2--Continued

WATER QUALITY DATA, WATER YEAR OCTOBER 1977 TO SEPTEMBER 1978--Continued

\begin{tabular}{|c|c|c|c|c|c|c|c|c|c|c|}
\hline DATE & $\begin{array}{l}\text { ALUM- } \\
\text { INUM, } \\
\text { DIS- } \\
\text { SOLVED } \\
(\mu G / L \\
\text { AS AL) }\end{array}$ & $\begin{array}{l}\text { SELE- } \\
\text { NIUM, } \\
\text { DIS- } \\
\text { SOLVED } \\
(\mu G / L \\
\text { AS SE) }\end{array}$ & $\begin{array}{l}\text { SELE- } \\
\text { NIUM, } \\
\text { TOTAL } \\
(\mu G / L \\
\text { AS SE) }\end{array}$ & $\begin{array}{c}\text { SOLIDS, } \\
\text { SUM OF } \\
\text { CONSTI- } \\
\text { TUENTS, } \\
\text { DIS- } \\
\text { SOLVED } \\
\text { (MG/L) }\end{array}$ & $\begin{array}{c}\text { SOLIDS, } \\
\text { DIS- } \\
\text { SOLVED } \\
\text { (TONS } \\
\text { PER } \\
\text { AC-FT) }\end{array}$ & $\begin{array}{c}\text { MERCURY } \\
\text { DIS- } \\
\text { SOLVED } \\
(\mu G / L \\
\text { AS HG) }\end{array}$ & $\begin{array}{c}\text { MERCURY } \\
\text { TOTAL } \\
\text { RECOV- } \\
\text { ERABLE } \\
(\mu \mathrm{G} / \mathrm{L} \\
\text { AS HG) }\end{array}$ & $\begin{array}{l}\text { ALKA- } \\
\text { LINITY } \\
\text { LAB } \\
\text { (MG/L } \\
\text { AS } \\
\text { CACO3) }\end{array}$ & $\begin{array}{c}\text { BICAR- } \\
\text { BONATE } \\
\text { IT-LAB } \\
\text { (MG/L AS } \\
\text { HCO3) }\end{array}$ & $\begin{array}{c}\text { CAR- } \\
\text { BONATE } \\
\text { IT-LAB } \\
(\mathrm{MG} / \mathrm{L} \text { AS } \\
\mathrm{CO} 3)\end{array}$ \\
\hline \multicolumn{11}{|l|}{ FEB } \\
\hline $11 \ldots$ & $<100$ & 500 & -- & 5300 & 7.2 & $<.1$ & -- & 250 & 300 & .00 \\
\hline$\underset{\text { MAR }}{25 \ldots}$ & $<100$ & 150 & -- & 4200 & 5.7 & $<.1$ & -- & 150 & 180 & .00 \\
\hline $11 \ldots$ & 10 & 210 & - & 4400 & 5.9 & $<.1$ & -- & 160 & 190 & .00 \\
\hline $20 \ldots$ & 20 & 160 & -- & 3800 & 5.1 & $<.1$ & -- & 190 & 230 & .00 \\
\hline \multicolumn{11}{|l|}{ APR } \\
\hline $01 \ldots$ & $<100$ & 180 & -- & 3600 & 4.9 & $<.1$ & -- & 220 & 270 & .00 \\
\hline $15 \ldots$ & $<100$ & 100 & -- & 3500 & 4.8 & $<.1$ & -- & 160 & 190 & .00 \\
\hline$\underset{\text { MAY }}{29} \ldots$ & $<100$ & 120 & -- & 3600 & 4.8 & $<.1$ & -- & 160 & 200 & .00 \\
\hline$\underset{\text { JUN }}{23} \ldots$ & $<100$ & 66 & -- & 3300 & 4.4 & $<.1$ & -- & 150 & 180 & .00 \\
\hline $07 \ldots$ & $<100$ & 76 & -- & 3600 & 4.9 & $<.1$ & -- & 110 & 130 & .00 \\
\hline $28 \ldots$ & $<100$ & 60 & -- & 3600 & 4.9 & $<.1$ & -- & 90 & 110 & .00 \\
\hline$\underset{\text { JUL }}{28} \ldots$ & -- & -- & 65 & -- & -- & -- & $<.1$ & -- & -- & -- \\
\hline $20 \ldots$ & 10 & 130 & -- & 3700 & 5.0 & $<.1$ & -- & 110 & 140 & .00 \\
\hline
\end{tabular}

WATER QUALITY DATA, WATER YEAR OCTOBER 1978 TO SEPTEMBER 1979

\begin{tabular}{|c|c|c|c|c|c|c|c|c|c|}
\hline DATE & $\begin{array}{l}\text { TEMPER- } \\
\text { ATURE } \\
\left({ }^{\circ} \mathrm{C}\right)\end{array}$ & $\begin{array}{l}\text { SPE- } \\
\text { CIFIC } \\
\text { CON- } \\
\text { DUCT- } \\
\text { ANCE } \\
(\mu S / C M)\end{array}$ & $\begin{array}{c}\text { OXYGEN, } \\
\text { DIS- } \\
\text { SOLVED } \\
\text { (MG/L) }\end{array}$ & $\begin{array}{c}\text { PH } \\
\text { (STAND- } \\
\text { ARD } \\
\text { UNITS) }\end{array}$ & $\begin{array}{c}\text { CARBON } \\
\text { DIOXIDE } \\
\text { DIS- } \\
\text { SOLVED } \\
\text { (MG/L } \\
\text { AS CO2) }\end{array}$ & $\begin{array}{c}\text { NITRO- } \\
\text { GEN, } \\
\text { NO2+NO3 } \\
\text { DIS- } \\
\text { SOLVED } \\
\text { (MG/L } \\
\text { AS N) }\end{array}$ & $\begin{array}{c}\text { PHOS- } \\
\text { PHATE, } \\
\text { ORTHO, } \\
\text { DIS- } \\
\text { SOLVED } \\
\text { (MG/L } \\
\text { AS PO4) }\end{array}$ & $\begin{array}{l}\text { PHOS- } \\
\text { PHORUS, } \\
\text { ORTHO, } \\
\text { DIS- } \\
\text { SOLVED } \\
\text { (MG/L } \\
\text { AS P) }\end{array}$ & $\begin{array}{l}\text { HARD- } \\
\text { NESS } \\
(\mathrm{MG} / \mathrm{L} \\
\text { AS } \\
\mathrm{CACO3})\end{array}$ \\
\hline \multicolumn{10}{|l|}{ MAR } \\
\hline \multicolumn{10}{|l|}{ APR } \\
\hline $06 \ldots$ & 8.0 & 3510 & 93.0 & 7.5 & 11 & 4.0 & .00 & $<.010$ & 2000 \\
\hline$\underset{\text { MAY }}{27 \ldots}$ & 11.0 & 3690 & 11.4 & 8.1 & 2.0 & 4.9 & .03 & .010 & 2300 \\
\hline $10 \ldots$ & 8.0 & 3120 & 14.9 & 8.2 & 2.2 & 6.8 & .21 & .070 & 1700 \\
\hline $25 \ldots$ & 15.5 & 3500 & 7.3 & 8.3 & 1.2 & 8.1 & .00 & $<.010$ & 2400 \\
\hline \multicolumn{10}{|l|}{ JUN } \\
\hline \multicolumn{10}{|l|}{ ЛUL } \\
\hline $27 \ldots$ & 20.0 & 4080 & 7.0 & 8.2 & 1.6 & 12 & .09 & .030 & 2500 \\
\hline
\end{tabular}


Table 5.--Water-quality data from Lysimeter 2--Continued

WATER QUALITY DATA, WATER YEAR OCTOBER 1978 TO SEPTEMBER 1979 - Continued

\begin{tabular}{|c|c|c|c|c|c|c|c|c|c|c|c|}
\hline DATE & $\begin{array}{l}\text { HARD- } \\
\text { NESS, } \\
\text { NONCAR- } \\
\text { BONATE } \\
\text { (MG/L AS } \\
\text { CACO3) }\end{array}$ & $\begin{array}{l}\text { CALCIUM } \\
\text { DIS - } \\
\text { SOLVED } \\
\text { (MG/L } \\
\text { AS CA) }\end{array}$ & $\begin{array}{l}\text { MAGNE- } \\
\text { SIUM, } \\
\text { DIS- } \\
\text { SOLVED } \\
\text { (MG/I } \\
\text { AS MG) }\end{array}$ & $\begin{array}{l}\text { SODIUM, } \\
\text { DIS- } \\
\text { SOLVED } \\
\text { (MG/L } \\
\text { AS NA) }\end{array}$ & $\begin{array}{c}\text { SODIUM } \\
\text { AD- } \\
\text { SORP- } \\
\text { TION } \\
\text { RATIO }\end{array}$ & $\begin{array}{r}\text { PERCENT } \\
\text { SODIUM }\end{array}$ & $\begin{array}{c}\text { SODIUM+ } \\
\text { POTAS- } \\
\text { SIUM } \\
\text { DIS- } \\
\text { SOLVED } \\
\text { (MG/L } \\
\text { AS NA) }\end{array}$ & $\begin{array}{l}\text { POTAS- } \\
\text { SIUM, } \\
\text { DIS- } \\
\text { SOLVED } \\
\text { (MG/L } \\
\text { AS K) }\end{array}$ & $\begin{array}{l}\text { CHLO- } \\
\text { RIDE, } \\
\text { DIS- } \\
\text { SOLVED } \\
\text { (MG/L } \\
\text { AS CL) }\end{array}$ & $\begin{array}{l}\text { SULFATE } \\
\text { DIS- } \\
\text { SOLVED } \\
\text { (MG/L } \\
\text { AS SO4) }\end{array}$ & $\begin{array}{l}\text { FLUO- } \\
\text { RIDE, } \\
\text { DIS- } \\
\text { SOLVED } \\
\text { (MG/L } \\
\text { AS F) }\end{array}$ \\
\hline \multicolumn{12}{|l|}{ MAR } \\
\hline$\underset{A P R}{23 \ldots}$ & 1700 & 300 & 270 & 52 & .5 & 6 & -- & 46 & 2.1 & 1800 & .40 \\
\hline $\begin{array}{r}06 \ldots \\
27 \ldots \\
\text { MAY }\end{array}$ & $\begin{array}{l}1800 \\
2200\end{array}$ & $\begin{array}{l}350 \\
380\end{array}$ & $\begin{array}{l}270 \\
340\end{array}$ & $\begin{array}{l}55 \\
64\end{array}$ & $\begin{array}{l}.5 \\
.6\end{array}$ & $\begin{array}{l}6 \\
5\end{array}$ & -- & $\begin{array}{l}35 \\
54\end{array}$ & $\begin{array}{l}2.6 \\
3.1\end{array}$ & $\begin{array}{l}2300 \\
2400\end{array}$ & $\begin{array}{l}.40 \\
.40\end{array}$ \\
\hline $\begin{array}{l}10 \ldots \\
25 \ldots \\
\text { JUN }\end{array}$ & $\begin{array}{l}1500 \\
2300\end{array}$ & $\begin{array}{l}270 \\
420\end{array}$ & $\begin{array}{l}250 \\
330\end{array}$ & $\begin{array}{r}110 \\
64\end{array}$ & ${ }^{1} .6$ & $\begin{array}{r}12 \\
5\end{array}$ & $\begin{array}{r}210 \\
74\end{array}$ & $\begin{array}{l}95 \\
10\end{array}$ & $\begin{array}{l}4.4 \\
3.9\end{array}$ & $\begin{array}{l}1800 \\
2300\end{array}$ & $\begin{array}{l}.40 \\
.40\end{array}$ \\
\hline$\underset{\text { JUL }}{16 \ldots}$ & 2300 & 410 & 330 & 96 & .9 & 8 & 180 & 87 & 5.1 & 2400 & .40 \\
\hline $27 \ldots$ & 2400 & 410 & 360 & 98 & .9 & 7 & 210 & 110 & 4.9 & 2500 & .40 \\
\hline DATE & $\begin{array}{l}\text { SILICA, } \\
\text { DIS- } \\
\text { SOLVED } \\
\text { (MG/L } \\
\text { AS } \\
\text { SIO2) }\end{array}$ & $\begin{array}{c}\text { ARSENIC } \\
\text { DIS- } \\
\text { SOLVED } \\
(\mu G / L \\
\text { AS AS) }\end{array}$ & $\begin{array}{c}\text { ARSENIC } \\
\text { TOTAL } \\
(\mu \mathrm{G} / \mathrm{L} \\
\text { AS AS) }\end{array}$ & $\begin{array}{l}\text { BORON, } \\
\text { DIS- } \\
\text { SOLVED } \\
(\mu G / L \\
\text { AS B) }\end{array}$ & $\begin{array}{l}\text { CADMIUM } \\
\text { DIS- } \\
\text { SOLVED } \\
(\mu G / L \\
\text { AS CD) }\end{array}$ & $\begin{array}{l}\text { CADMIUM } \\
\text { SUS- } \\
\text { PENDED } \\
\text { RECOV- } \\
\text { ERABLE } \\
(\mu \mathrm{G} / \mathrm{L} \\
\text { AS CD })\end{array}$ & $\begin{array}{l}\text { CADMIUM } \\
\text { TOTAL } \\
\text { RECOV- } \\
\text { ERABLE } \\
(\mu G / L \\
\text { AS CD) }\end{array}$ & $\begin{array}{l}\text { COPPER, } \\
\text { DIS- } \\
\text { SOLVED } \\
(\mu \mathrm{G} / \mathrm{L} \\
\text { AS CU) }\end{array}$ & $\begin{array}{l}\text { COPPER, } \\
\text { SUS - } \\
\text { PENDED } \\
\text { RECOV- } \\
\text { ERABLE } \\
\text { ( } \mu \mathrm{G} / \mathrm{L} \\
\text { AS CU) }\end{array}$ & $\begin{array}{l}\text { COPPER, } \\
\text { TOTAL } \\
\text { RECOV- } \\
\text { ERABLE } \\
(\mu G / L \\
\text { AS CU) }\end{array}$ & $\begin{array}{l}\text { IRON, } \\
\text { SUS- } \\
\text { PENDED } \\
\text { RECOV- } \\
\text { ERABLE } \\
(\mu G / L \\
\text { AS FE) }\end{array}$ \\
\hline
\end{tabular}

\begin{tabular}{|c|c|c|c|c|c|c|c|c|c|c|c|}
\hline MAR & & & & & & & & & & & \\
\hline $23 \ldots$ & 7.9 & 1 & 1 & 50 & $<2$ & 0 & ND & ND & 1 & $<2$ & 30 \\
\hline APR & & & & & & & & & & & \\
\hline $06 \ldots$ & 7.5 & 1 & 1 & 50 & ND & 1 & $<2$ & 2 & 4 & 6 & 0 \\
\hline $27 \ldots$ & 8.0 & 1 & 1 & 60 & ND & 0 & ND & 2 & 0 & 2 & 10 \\
\hline MAY & & & & & & & & & & & \\
\hline $10 \ldots$ & 11 & 1 & 1 & 60 & ND & 0 & ND & ND & 2 & 2 & 0 \\
\hline $25 \ldots$ & 7.1 & $<1$ & 1 & 50 & $<2$ & 0 & ND & $<2$ & 5 & 6 & 30 \\
\hline JUN & & & & & & & & & & & \\
\hline $16 \ldots$ & 10 & 1 & 1 & 50 & ND & 0 & ND & 2 & 6 & 8 & -- \\
\hline JUL & & & & & & & & & & & \\
\hline $27 \ldots$ & 16 & 1 & 1 & 60 & ND & 1 & $<2$ & 3 & 1 & 4 & 60 \\
\hline
\end{tabular}


Table 5.--Water-quality data from Lysimeter 2--Continued

WATER QUALITY DATA, WATER YEAR OCTOBER 1978 TO SEPTEMBER 1979--Continued

\begin{tabular}{|c|c|c|c|c|c|c|c|c|c|c|c|}
\hline DATE & $\begin{array}{l}\text { IRON, } \\
\text { TOTAL } \\
\text { RECOV- } \\
\text { ERABLE } \\
(\mu G / L \\
\text { AS FE) }\end{array}$ & $\begin{array}{l}\text { IRON, } \\
\text { DIS- } \\
\text { SOLVED } \\
(\mu G / L \\
\text { AS FE) }\end{array}$ & $\begin{array}{l}\text { LEAD, } \\
\text { DIS- } \\
\text { SOLVED } \\
\text { ( } \mu G / L \\
\text { AS PB) }\end{array}$ & $\begin{array}{l}\text { LEAD, } \\
\text { SUS- } \\
\text { PENDED } \\
\text { RECOV- } \\
\text { ERABLE } \\
(\mu G / L \\
\text { AS PB) }\end{array}$ & $\begin{array}{l}\text { LEAD, } \\
\text { TOTAL } \\
\text { RECOV- } \\
\text { ERABLE } \\
(\mu G / L \\
\text { AS PB) }\end{array}$ & $\begin{array}{l}\text { MANGA- } \\
\text { NESE, } \\
\text { SUS- } \\
\text { PENDED } \\
\text { RECOV. } \\
(\mu G / L \\
\text { AS MN) }\end{array}$ & $\begin{array}{l}\text { MANGA- } \\
\text { NESE, } \\
\text { TOTAL } \\
\text { RECOV- } \\
\text { ERABLE } \\
(\mu G / L \\
\text { AS MN) }\end{array}$ & $\begin{array}{l}\text { MANGA- } \\
\text { NESE, } \\
\text { DIS- } \\
\text { SOLVED } \\
(\mu G / L \\
\text { AS MN) }\end{array}$ & $\begin{array}{l}\text { MOLYB- } \\
\text { DENUM, } \\
\text { DIS- } \\
\text { SOLVED } \\
(\mu G / L \\
\text { AS MO) }\end{array}$ & $\begin{array}{l}\text { MOLYB- } \\
\text { DENUM, } \\
\text { SUS- } \\
\text { PENDED } \\
\text { RECOV. } \\
(\mu G / L \\
\text { AS MO) }\end{array}$ & $\begin{array}{l}\text { MOLYB- } \\
\text { DENUM, } \\
\text { TOTAL } \\
\text { RECOV- } \\
\text { ERABLE } \\
(\mu G / L \\
\text { AS MO) }\end{array}$ \\
\hline
\end{tabular}

\begin{tabular}{|c|c|c|c|c|c|c|c|c|c|c|c|}
\hline \multicolumn{12}{|l|}{ MAR } \\
\hline $\begin{array}{l}23 \ldots \\
\mathrm{APR}\end{array}$ & 60 & 30 & 5 & 6 & 11 & 0 & $<10$ & $<10$ & 4 & 0 & 4 \\
\hline $06 \ldots$ & 40 & 40 & $<2$ & 9 & 10 & 0 & $<10$ & $<10$ & 3 & 2 & 5 \\
\hline $27 \ldots$ & 30 & 20 & ND & 62 & 62 & 0 & $<10$ & $<10$ & 2 & 3 & 5 \\
\hline MAY & & & & & & & & & & & \\
\hline $10 \ldots$ & 30 & 30 & ND & 9 & 9 & 10 & 20 & $<10$ & 3 & 1 & 4 \\
\hline$\underset{\text { JUN }}{25 \ldots}$ & 40 & $<10$ & ND & 5 & 5 & 0 & $<10$ & $<10$ & $<1$ & 5 & 5 \\
\hline $16 \ldots$ & -- & 20 & ND & 8 & 8 & - & -. & $<10$ & 2 & 0 & 2 \\
\hline $27 \ldots$ & 70 & $<10$ & ND & 4 & 4 & 0 & 20 & 20 & 3 & 0 & 2 \\
\hline DATE & $\begin{array}{l}\text { NICKEL, } \\
\text { DIS- } \\
\text { SOLVED } \\
(\mu G / L \\
\text { AS NI) }\end{array}$ & $\begin{array}{c}\text { NICKEL, } \\
\text { SUS- } \\
\text { PENDED } \\
\text { RECOV- } \\
\text { ERABLE } \\
(\mu G / L \\
\text { AS NI) }\end{array}$ & $\begin{array}{c}\text { NICKEL, } \\
\text { TOTAL } \\
\text { RECOV- } \\
\text { ERABLE } \\
(\mu G / L \\
\text { AS NI) }\end{array}$ & $\begin{array}{l}\text { VANA- } \\
\text { DIUM, } \\
\text { DIS- } \\
\text { SOLVED } \\
(\mu G / L \\
\text { AS V) }\end{array}$ & $\begin{array}{l}\text { ZINC, } \\
\text { DIS- } \\
\text { SOLVED } \\
(\mu \mathrm{G} / \mathrm{L} \\
\text { AS ZN) }\end{array}$ & $\begin{array}{l}\text { ZINC, } \\
\text { SUS- } \\
\text { PENDED } \\
\text { RECOV- } \\
\text { ERABLE } \\
(\mu G / L \\
\text { AS ZN) }\end{array}$ & $\begin{array}{l}\text { ZINC, } \\
\text { TOTAL } \\
\text { RECOV- } \\
\text { ERABLE } \\
(\mu G / L \\
\text { AS ZN) }\end{array}$ & $\begin{array}{l}\text { ALUM- } \\
\text { INUM, } \\
\text { TOTAL } \\
\text { RECOV- } \\
\text { ERABLE } \\
(\mu G / L \\
\text { AS AL) }\end{array}$ & $\begin{array}{l}\text { ALUM- } \\
\text { INUM, } \\
\text { DIS- } \\
\text { SOLVED } \\
(\mu G / L \\
\text { AS AL) }\end{array}$ & $\begin{array}{l}\text { ALUM- } \\
\text { INUM, } \\
\text { SUS- } \\
\text { PENDED } \\
\text { RECOV. } \\
(\mu G / L \\
\text { AS AL) }\end{array}$ & $\begin{array}{l}\text { SELE- } \\
\text { NIUM, } \\
\text { DIS- } \\
\text { SOLVED } \\
(\mu G / L \\
\text { AS SE) }\end{array}$ \\
\hline
\end{tabular}

\begin{tabular}{|c|c|c|c|c|c|c|c|c|c|c|c|}
\hline \multicolumn{12}{|c|}{ MAR } \\
\hline $23 \ldots$ & 2 & 2 & 4 & 2 & 20 & 10 & 30 & 40 & $<100$ & 40 & 120 \\
\hline \multicolumn{12}{|l|}{ APR } \\
\hline $06 \ldots$ & 4 & 5 & 9 & 2 & 20 & 10 & 30 & 60 & $<100$ & 60 & 140 \\
\hline $27 \ldots$ & ND & 0 & ND & 2 & 30 & 0 & 30 & 50 & 30 & 20 & 180 \\
\hline \multicolumn{12}{|l|}{ MAY } \\
\hline $10 \ldots$ & ND & 4 & 4 & 9 & 20 & 20 & 40 & 90 & 20 & 70 & 150 \\
\hline $25 \ldots$ & ND & 2 & 2 & 3 & 20 & 0 & 20 & 80 & $<100$ & 80 & 190 \\
\hline \multicolumn{12}{|l|}{ JUN } \\
\hline $16 \ldots$ & 2 & 4 & 6 & 5 & 20 & 10 & 30 & 60 & $<100$ & 60 & 220 \\
\hline \multicolumn{12}{|l|}{ JUL } \\
\hline $27 \ldots$ & 2 & 5 & 7 & 4 & $<20$ & 10 & 20 & $<100$ & $<100$ & 100 & 230 \\
\hline
\end{tabular}


Table 5.--Water-quality data from Lysimeter 2--Continued

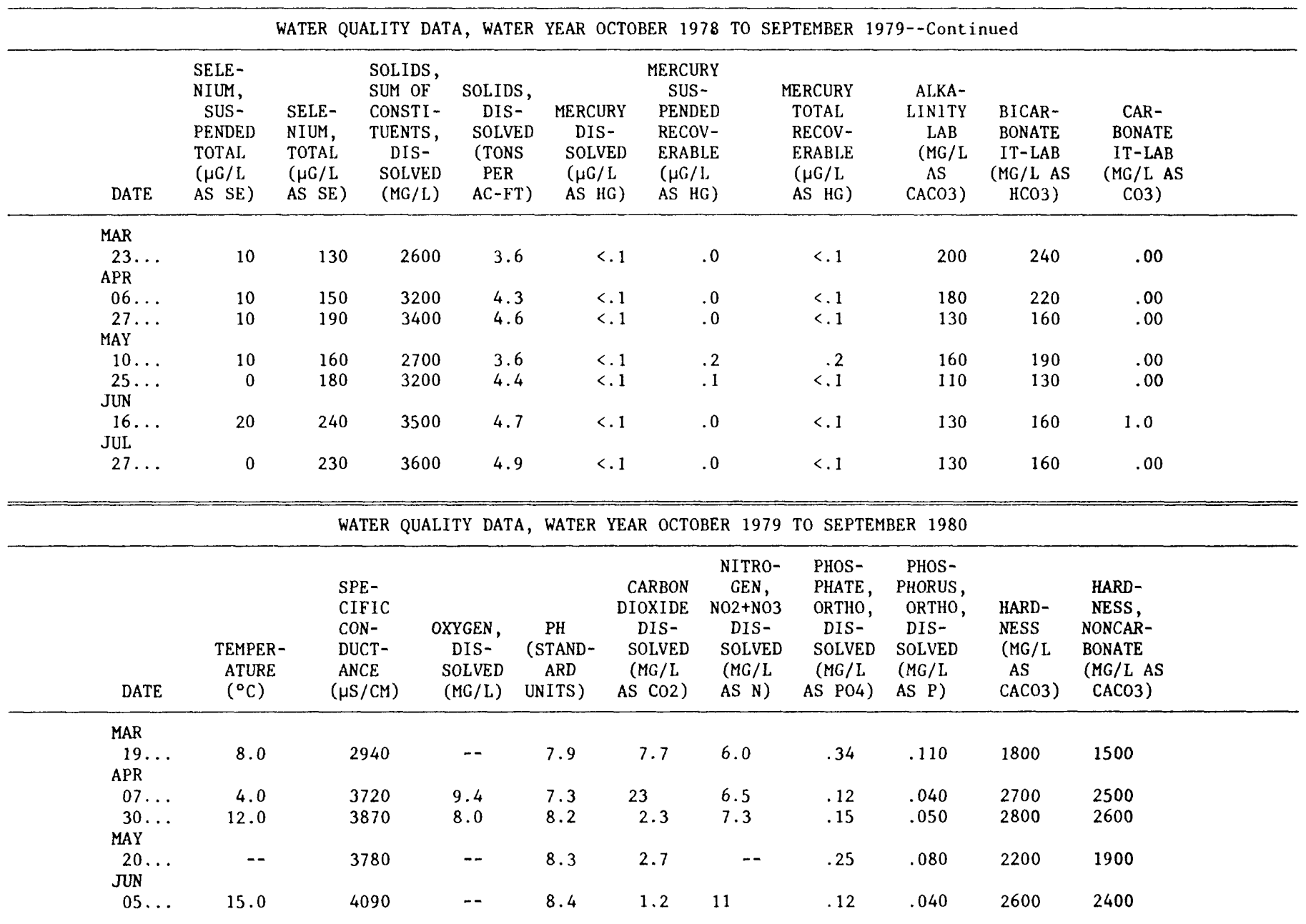


Table 5.--Water-quality data from Lysimeter 2--Continued

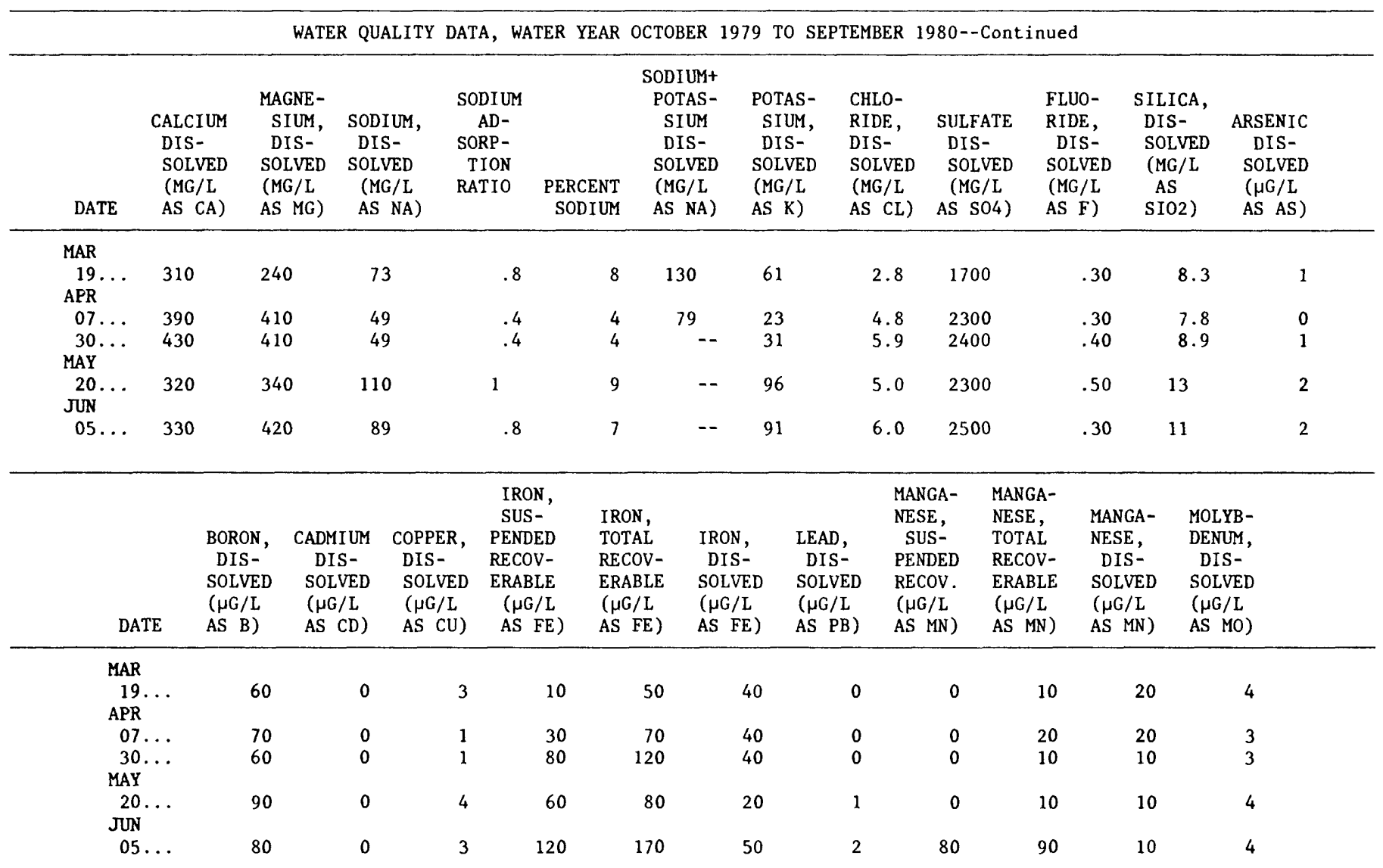


Table 5.--Water-quality data from Lysimeter 2--Continued

WATER QUALITY DATA, WATER YEAR OCTOBER 1979 TO SEPTEMBER 1980--Continued

\begin{tabular}{|c|c|c|c|c|c|c|c|c|c|c|}
\hline DATE & $\begin{array}{l}\text { NICKEL, } \\
\text { DIS- } \\
\text { SOLVED } \\
(\mu G / L \\
\text { AS NI) }\end{array}$ & $\begin{array}{l}\text { VANA- } \\
\text { DIUM, } \\
\text { DIS- } \\
\text { SOLVED } \\
(\mu G / L \\
\text { AS V) }\end{array}$ & $\begin{array}{l}\text { ZINC, } \\
\text { DIS- } \\
\text { SOLVED } \\
(\mu G / I \\
\text { AS ZN) }\end{array}$ & $\begin{array}{l}\text { ALUM- } \\
\text { INUM, } \\
\text { DIS- } \\
\text { SOLVED } \\
(\mu G / L \\
\text { AS AL) }\end{array}$ & $\begin{array}{l}\text { SELE- } \\
\text { NIUM, } \\
\text { DIS- } \\
\text { SOLVED } \\
(\mu G / L \\
\text { AS SE) }\end{array}$ & $\begin{array}{l}\text { SOLIDS, } \\
\text { SUM OF } \\
\text { CONSTI- } \\
\text { TUENTS, } \\
\text { DIS- } \\
\text { SOLVED } \\
\text { (MG/L) }\end{array}$ & $\begin{array}{c}\text { SOLIDS, } \\
\text { DIS- } \\
\text { SOLVED } \\
\text { (TONS } \\
\text { PER } \\
\text { AC-FT) }\end{array}$ & $\begin{array}{c}\text { MERCURY } \\
\text { DIS- } \\
\text { SOLVED } \\
(\mu G / L \\
\text { AS HG) }\end{array}$ & $\begin{array}{c}\text { ALKA- } \\
\text { LINITY } \\
\text { LAB } \\
\text { (MG/L } \\
\text { AS } \\
\text { CACO3) }\end{array}$ & $\begin{array}{c}\text { BICAR- } \\
\text { BONATE } \\
\text { IT-LAB } \\
\text { (MG/L AS } \\
\text { HCO3) }\end{array}$ \\
\hline \multicolumn{11}{|l|}{ MAR } \\
\hline $\begin{array}{c}19 \ldots \\
\text { APR }\end{array}$ & 2 & 6 & 20 & 0 & 66 & 2600 & 3.5 & .0 & 300 & 366 \\
\hline $07 \ldots$ & 2 & 1 & 10 & 20 & 170 & 3400 & 4.6 & .0 & 230 & 281 \\
\hline$\underset{M A Y}{30 \ldots}$ & 4 & 2 & 10 & 0 & 220 & 3500 & 4.7 & .0 & 190 & 232 \\
\hline$\underset{\text { JUN }}{20} \cdots$ & 3 & 11 & 20 & 10 & 200 & 3400 & 4.6 & .0 & 280 & 341 \\
\hline $05 \ldots$ & 3 & 10 & 0 & 10 & 240 & 3600 & 4.9 & .0 & 160 & 195 \\
\hline
\end{tabular}


Table 6.-Water-quality data from Lysimeter 3

WATER QUALITY DATA, WATER YEAR OCTOBER 1977 TO SEPTEMBER 1978

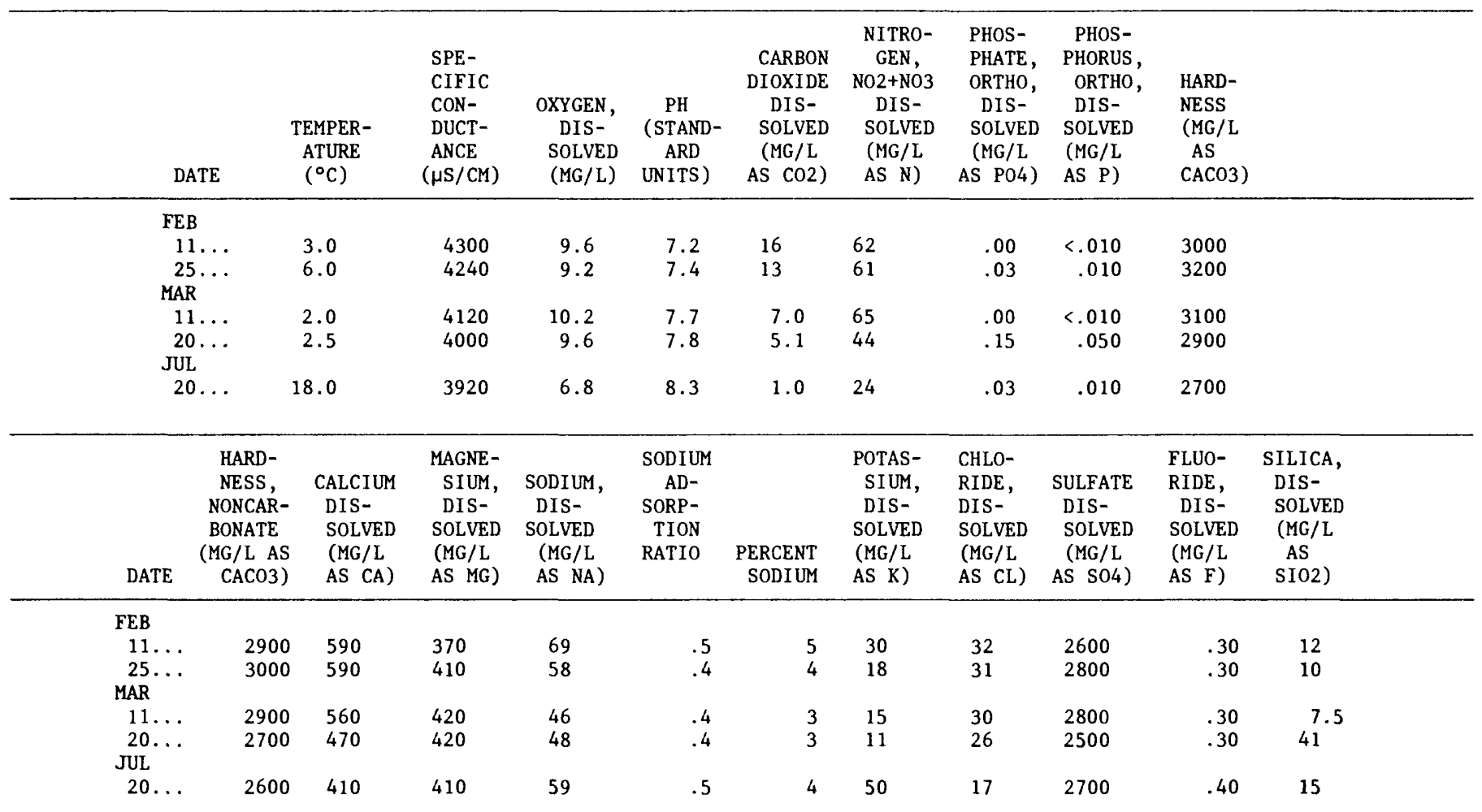


Table 6.--Water-quality data from Lysimeter 3--Continued

WATER QUALITY DATA, WATER YEAR OCTOBER 1977 TO SEPTEMBER 1978--Continued

\begin{tabular}{|c|c|c|c|c|c|c|c|c|c|c|c|c|c|c|c|c|c|c|}
\hline DATE & \multicolumn{2}{|c|}{$\begin{array}{l}\text { ARSENIC } \\
\text { DIS- } \\
\text { SOLVED } \\
(\mu \mathrm{G} / \mathrm{L} \\
\text { AS AS) }\end{array}$} & \multicolumn{2}{|c|}{$\begin{array}{l}\text { BORON, } \\
\text { DIS- } \\
\text { SOLVED } \\
(\mu \mathrm{G} / \mathrm{L} \\
\text { AS B) }\end{array}$} & \multicolumn{2}{|c|}{$\begin{array}{l}\text { CADMIUM } \\
\text { DIS- } \\
\text { SOLVED } \\
(\mu \mathrm{G} / \mathrm{L} \\
\text { AS CD) }\end{array}$} & \multicolumn{2}{|c|}{$\begin{array}{l}\text { COPPER, } \\
\text { DIS- } \\
\text { SOLVED } \\
(\mu \mathrm{G} / \mathrm{L} \\
\text { AS CU) }\end{array}$} & \multicolumn{2}{|c|}{$\begin{array}{l}\text { IRON, } \\
\text { DIS- } \\
\text { SOLVED } \\
(\mu \mathrm{G} / \mathrm{L} \\
\text { AS FE) }\end{array}$} & \multicolumn{2}{|c|}{$\begin{array}{l}\text { LEAD, } \\
\text { DIS- } \\
\text { SOLVED } \\
(\mu \mathrm{G} / \mathrm{L} \\
\text { AS PB) }\end{array}$} & \multirow[t]{2}{*}{$\begin{array}{l}\text { MANGA- } \\
\text { NESE, } \\
\text { DIS- } \\
\text { SOLVED } \\
(\mu G / L \\
\text { AS MN) }\end{array}$} & \multirow[t]{2}{*}{$\begin{array}{l}\text { MOLYB- } \\
\text { DENUM, } \\
\text { DIS- } \\
\text { SOLVED } \\
(\mu \mathrm{G} / \mathrm{L} \\
\text { AS MO) }\end{array}$} & \multirow[t]{2}{*}{$\begin{array}{l}\text { NICKEL, } \\
\text { DIS- } \\
\text { SOLVED } \\
(\mu \mathrm{G} / \mathrm{L} \\
\text { AS NI) }\end{array}$} & \multirow[t]{2}{*}{$\begin{array}{l}\text { VANA- } \\
\text { DIUM, } \\
\text { DIS- } \\
\text { SOLVED } \\
(\mu G / L \\
\text { AS V) }\end{array}$} & \multicolumn{2}{|c|}{$\begin{array}{c}\text { ZINC, } \\
\text { DIS- } \\
\text { SOLVED } \\
(\mu \mathrm{G} / \mathrm{L} \\
\text { AS ZN) }\end{array}$} \\
\hline \multicolumn{15}{|l|}{ FEB } & & & & \\
\hline $11 \ldots$ & & $<1$ & & 70 & & ND & & $<2$ & & $<10$ & & ND & 20 & $<1$ & 4 & 0 & & 20 \\
\hline$\underset{M A R}{25 \ldots}$ & & 1 & & 60 & & ND & & 2 & & $<10$ & & 4 & 20 & 4 & 2 & 0 & & 20 \\
\hline $11 \ldots$ & & 1 & & 50 & & $<2$ & & 2 & & $<10$ & & ND & 20 & 2 & 5 & 0 & & 20 \\
\hline $20 \ldots$ & & $<1$ & & 50 & & 2 & & 2 & & 20 & & 6 & 20 & 4 & ND & 0 & & 20 \\
\hline \multicolumn{19}{|l|}{ JUL } \\
\hline \multirow[t]{2}{*}{$20 \ldots$} & & 2 & & 70 & & 2 & & 3 & & 80 & & -- & 20 & 5 & 7 & -- & & -- \\
\hline & TE & $\begin{array}{r}\text { AN } \\
\text { MO } \\
D \\
\text { SO } \\
(\mu \\
\text { AS }\end{array}$ & $\begin{array}{l}\text { I- } \\
Y, \\
\text { S- } \\
\text { VED } \\
\text { /L } \\
\text { SB) }\end{array}$ & & $\begin{array}{l}\text { UM- } \\
\text { UM, } \\
\text { IS- } \\
\text { LVED } \\
\text { G/L } \\
\text { AL) }\end{array}$ & $\begin{array}{r}\text { SE } \\
\text { NI } \\
\text { D } \\
\text { SO } \\
(\mu \\
\text { AS }\end{array}$ & $\begin{array}{l}\text { ELE- } \\
\text { IUM, } \\
\text { DIS- } \\
\text { OLVED } \\
\mu G / L \\
S \text { SE) }\end{array}$ & $\begin{array}{l}\text { SOLI } \\
\text { SUM } \\
\text { CONS } \\
\text { TUEN } \\
\text { DI } \\
\text { SOI } \\
\text { (MC }\end{array}$ & $\begin{array}{l}\text { DS, } \\
\text { OF } \\
\text { TI- } \\
\text { TS, } \\
\text { S- } \\
\text { VED } \\
\text { /L) }\end{array}$ & $\begin{array}{r}\text { SOL } \\
\text { D } \\
\text { SO } \\
\text { (TC } \\
\text { PI } \\
\text { AC }\end{array}$ & $\begin{array}{l}\text { DS, } \\
\text { S- } \\
\text { VED } \\
\text { NS } \\
\text { R } \\
\text { FT) }\end{array}$ & & $\begin{array}{l}\text { MERCURY } \\
\text { DIS- } \\
\text { SOLVED } \\
(\mu G / L \\
\text { AS HG) }\end{array}$ & $\begin{array}{c}\text { ALKA- } \\
\text { LINITY } \\
\text { LAB } \\
\text { (MG/L } \\
\text { AS } \\
\text { CACO3) }\end{array}$ & $\begin{array}{l}\text { BICAR- } \\
\text { BONATE } \\
\text { IT-LAB } \\
(\mathrm{MG} / \mathrm{L} \text { AS } \\
\text { HCO3) }\end{array}$ & $\begin{array}{r}\text { CAP } \\
\text { BON } \\
\text { IT- } \\
\text { (MG/ } \\
\text { CO }\end{array}$ & $\begin{array}{l}\mathrm{TE} \\
\mathrm{AB} \\
\mathrm{AS}\end{array}$ & \\
\hline \multicolumn{19}{|c|}{ FEB } \\
\hline \multirow{2}{*}{\multicolumn{3}{|c|}{$\begin{array}{r}11 \ldots \\
25 \ldots \\
\text { MAR }\end{array}$}} & -- & \multirow{2}{*}{\multicolumn{3}{|c|}{$\begin{array}{l}<100 \\
<100\end{array}$}} & 210 & \multirow{2}{*}{\multicolumn{2}{|c|}{$\begin{array}{l}4100 \\
4300\end{array}$}} & \multirow{2}{*}{\multicolumn{3}{|c|}{$\begin{array}{l}5.5 \\
5.8\end{array}$}} & $<.1$ & 130 & 160 & \multicolumn{3}{|c|}{.00} \\
\hline & & & $<1$ & & & & 130 & & & & & & $<.1$ & 160 & 200 & & 00 & \\
\hline & 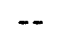 & & $<100$ & & 180 & & 300 & \multicolumn{3}{|c|}{5.8} & $<.1$ & 180 & 220 & \multicolumn{3}{|c|}{.00} \\
\hline \multicolumn{3}{|c|}{$\underset{\text { JUL }}{20 \ldots}$} & 1 & & 30 & & 90 & & 800 & \multicolumn{3}{|c|}{5.2} & $<.1$ & 160 & 200 & \multicolumn{3}{|c|}{.00} \\
\hline \multicolumn{3}{|c|}{$20 \ldots$} & -- & & 10 & & 100 & & 800 & \multicolumn{3}{|c|}{5.2} & $<.1$ & 110 & 130 & \multicolumn{3}{|c|}{.00} \\
\hline
\end{tabular}


Table 6.--Water-quality data from Lysimeter 3--Continued

WATER QUALITY DATA, WATER YEAR OCTOBER 1978 TO SEPTEMBER 1979

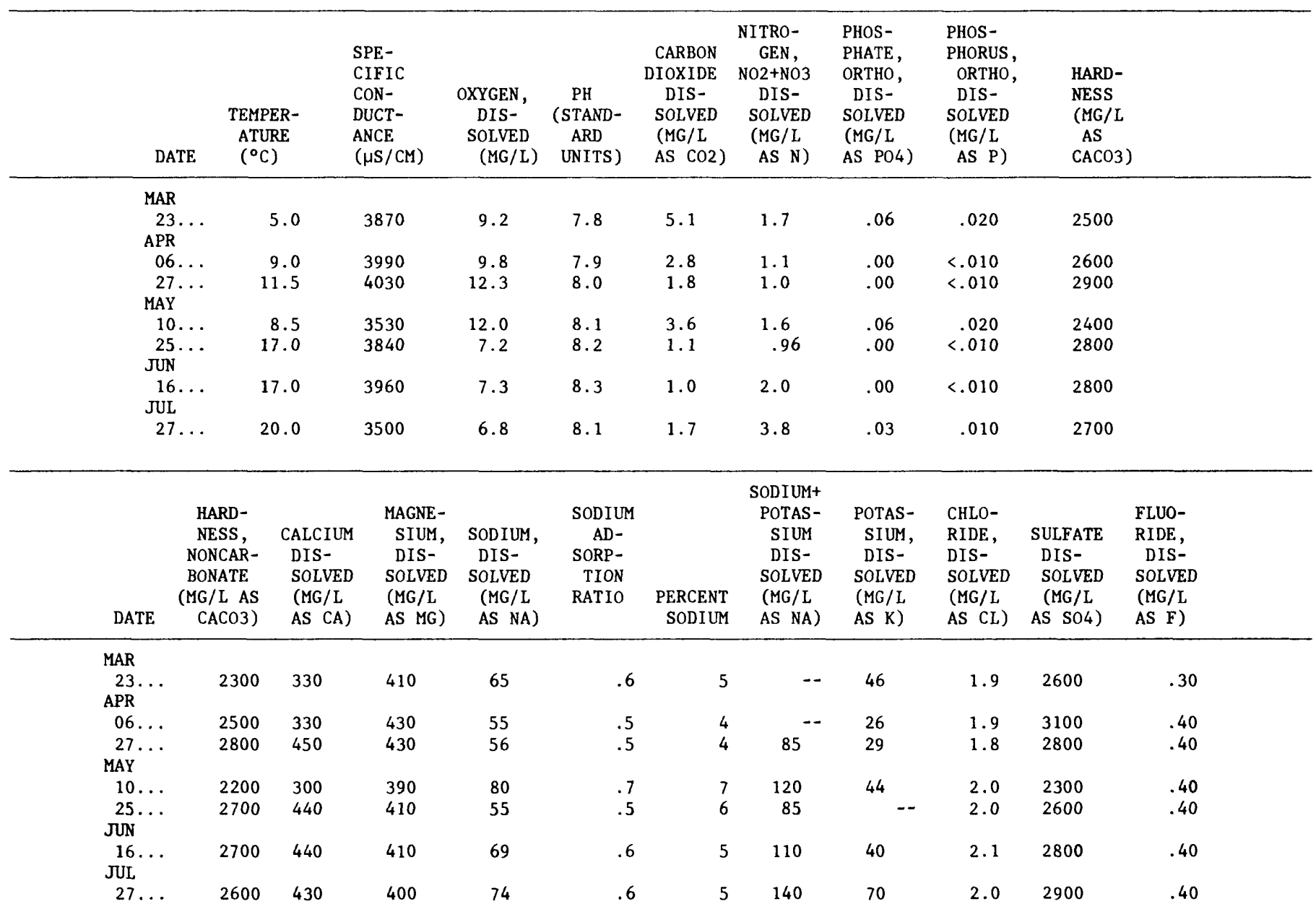




\begin{tabular}{|c|c|c|c|c|c|c|c|c|c|c|c|}
\hline & & WATER QU & ALITY DAT & WATER & YEAR OCTO & BER 1978 & TO SEPTEM & BER 1979- & -Continue & & \\
\hline DATE & $\begin{array}{l}\text { SILICA, } \\
\text { DIS- } \\
\text { SOLVED } \\
\text { (MG/L } \\
\text { AS } \\
\text { SIO2) }\end{array}$ & $\begin{array}{c}\text { ARSENIC } \\
\text { DIS- } \\
\text { SOLVED } \\
\text { ( } \mu \mathrm{G} / \mathrm{L} \\
\text { AS AS) }\end{array}$ & $\begin{array}{c}\text { ARSENIC } \\
\text { TOTAL } \\
(\mu \mathrm{G} / \mathrm{L} \\
\text { AS AS) }\end{array}$ & $\begin{array}{l}\text { BORON, } \\
\text { DIS- } \\
\text { SOLVED } \\
(\mu G / L \\
\text { AS B) }\end{array}$ & $\begin{array}{c}\text { CADMIUM } \\
\text { DIS- } \\
\text { SOLVED } \\
(\mu G / L \\
\text { AS CD) }\end{array}$ & $\begin{array}{l}\text { CADMIUM } \\
\text { SUS- } \\
\text { PENDED } \\
\text { RECOV- } \\
\text { ERABLE } \\
(\mu G / L \\
\text { AS CD) }\end{array}$ & $\begin{array}{l}\text { CADMIUM } \\
\text { TOTAL } \\
\text { RECOV- } \\
\text { ERABLE } \\
(\mu G / L \\
\text { AS CD })\end{array}$ & $\begin{array}{l}\text { COPPER, } \\
\text { DIS- } \\
\text { SOLVED } \\
(\mu \mathrm{G} / \mathrm{L} \\
\text { AS CU) }\end{array}$ & $\begin{array}{l}\text { COPPER, } \\
\text { SUS- } \\
\text { PENDED } \\
\text { RECOV- } \\
\text { ERABLE } \\
\text { ( } \mu \mathrm{G} / \mathrm{L} \\
\text { AS CU) }\end{array}$ & $\begin{array}{l}\text { COPPER, } \\
\text { TOTAL } \\
\text { RECOV- } \\
\text { ERABLE } \\
\text { ( } \mu \mathrm{G} / \mathrm{L} \\
\text { AS CU) }\end{array}$ & $\begin{array}{l}\text { IRON, } \\
\text { SUS- } \\
\text { PENDED } \\
\text { RECOV- } \\
\text { ERABLE } \\
\text { ( } \mu \mathrm{G} / \mathrm{L} \\
\text { AS FE) }\end{array}$ \\
\hline \multicolumn{12}{|l|}{ MAR } \\
\hline$\underset{A P R}{23 \ldots}$ & 7.7 & 1 & $<1$ & 50 & ND & 13 & 13 & 2 & 0 & $<2$ & 20 \\
\hline $06 \ldots$ & 6.5 & 1 & 1 & 40 & ND & 1 & $<2$ & $<2$ & 3 & 4 & 20 \\
\hline $27 \ldots$ & 6.9 & $<1$ & 1 & 50 & ND & 0 & ND & $<2$ & 4 & 5 & 20 \\
\hline $10 \ldots$ & 8.2 & 1 & 1 & 50 & ND & 0 & ND & ND & 2 & 2 & 10 \\
\hline $25 \ldots$ & 7.1 & $<1$ & 1 & 50 & $<2$ & 0 & ND & $<2$ & 4 & 5 & 10 \\
\hline $16 \ldots$ & 8.1 & 1 & 1 & 40 & ND & 0 & ND & ND & 9 & 9 & -- \\
\hline $27 \ldots$ & 11 & 1 & 1 & 30 & ND & 1 & $<2$ & $<2$ & 1 & 2 & 10 \\
\hline DATE & $\begin{array}{l}\text { IRON, } \\
\text { TOTAL } \\
\text { RECOV- } \\
\text { ERABLE } \\
(\mu G / L \\
\text { AS FE) }\end{array}$ & $\begin{array}{l}\text { IRON, } \\
\text { DIS- } \\
\text { SOLVED } \\
(\mu \mathrm{G} / \mathrm{L} \\
\text { AS FE) }\end{array}$ & $\begin{array}{l}\text { LEAD, } \\
\text { DIS- } \\
\text { SOLVED } \\
(\mu G / L \\
\text { AS PB) }\end{array}$ & $\begin{array}{l}\text { LEAD, } \\
\text { SUS- } \\
\text { PENDED } \\
\text { RECOV- } \\
\text { ERABLE } \\
(\mu G / L \\
\text { AS PB) }\end{array}$ & $\begin{array}{l}\text { LEAD, } \\
\text { TOTAL } \\
\text { RECOV- } \\
\text { ERABLE } \\
(\mu G / L \\
\text { AS PB) }\end{array}$ & $\begin{array}{l}\text { MANGA- } \\
\text { NESE, } \\
\text { SUS- } \\
\text { PENDED } \\
\text { RECOV. } \\
(\mu G / L \\
\text { AS MN) }\end{array}$ & $\begin{array}{l}\text { MANGA- } \\
\text { NESE, } \\
\text { TOTAL } \\
\text { RECOV- } \\
\text { ERABLE } \\
(\mu G / I \\
\text { AS MN) }\end{array}$ & $\begin{array}{l}\text { MANGA- } \\
\text { NESE, } \\
\text { DIS- } \\
\text { SOLVED } \\
(\mu G / L \\
\text { AS MN) }\end{array}$ & $\begin{array}{l}\text { MOLYB- } \\
\text { DENUM, } \\
\text { DIS- } \\
\text { SOLVED } \\
(\mu \mathrm{G} / \mathrm{L} \\
\text { AS MO) }\end{array}$ & $\begin{array}{l}\text { MOLYB- } \\
\text { DENUM, } \\
\text { SUS- } \\
\text { PENDED } \\
\text { RECOV. } \\
(\mu G / L \\
\text { AS MO) }\end{array}$ & $\begin{array}{l}\text { MOLYB- } \\
\text { DENUM, } \\
\text { TOTAL } \\
\text { RECOV- } \\
\text { ERABLE } \\
\text { ( } \mu G / L \\
\text { AS MO) }\end{array}$ \\
\hline MAR & & & & & & & & & & & \\
\hline$\underset{\mathrm{APR}}{23 . \cdots}$ & 60 & 40 & 2 & 130 & 130 & 0 & $<10$ & $<10$ & 3 & 1 & 4 \\
\hline $06 \ldots$ & 60 & 40 & $<2$ & 8 & 9 & 10 & 20 & $<10$ & 3 & 2 & 5 \\
\hline$\underset{M A Y}{27} \cdots$ & 40 & 20 & ND & 13 & 13 & 0 & $<10$ & $<10$ & 2 & 1 & 3 \\
\hline $10 \ldots$ & 30 & 20 & ND & 17 & 17 & 10 & 20 & $<10$ & 1 & 2 & 3 \\
\hline JUN & 20 & $<10$ & ND & 3 & 3 & 0 & 20 & 20 & 4 & 1 & 5 \\
\hline $\begin{array}{l}16 . \\
\text { JUL }\end{array}$ & - & $<10$ & ND & 8 & 8 & - & -- & $<10$ & 1 & 1 & 2 \\
\hline $27 \ldots$ & 30 & 20 & ND & 3 & 3 & 0 & 20 & 20 & 2 & 0 & 2 \\
\hline
\end{tabular}


Table 6.--Water-quality data from Lysimeter 3--Continued

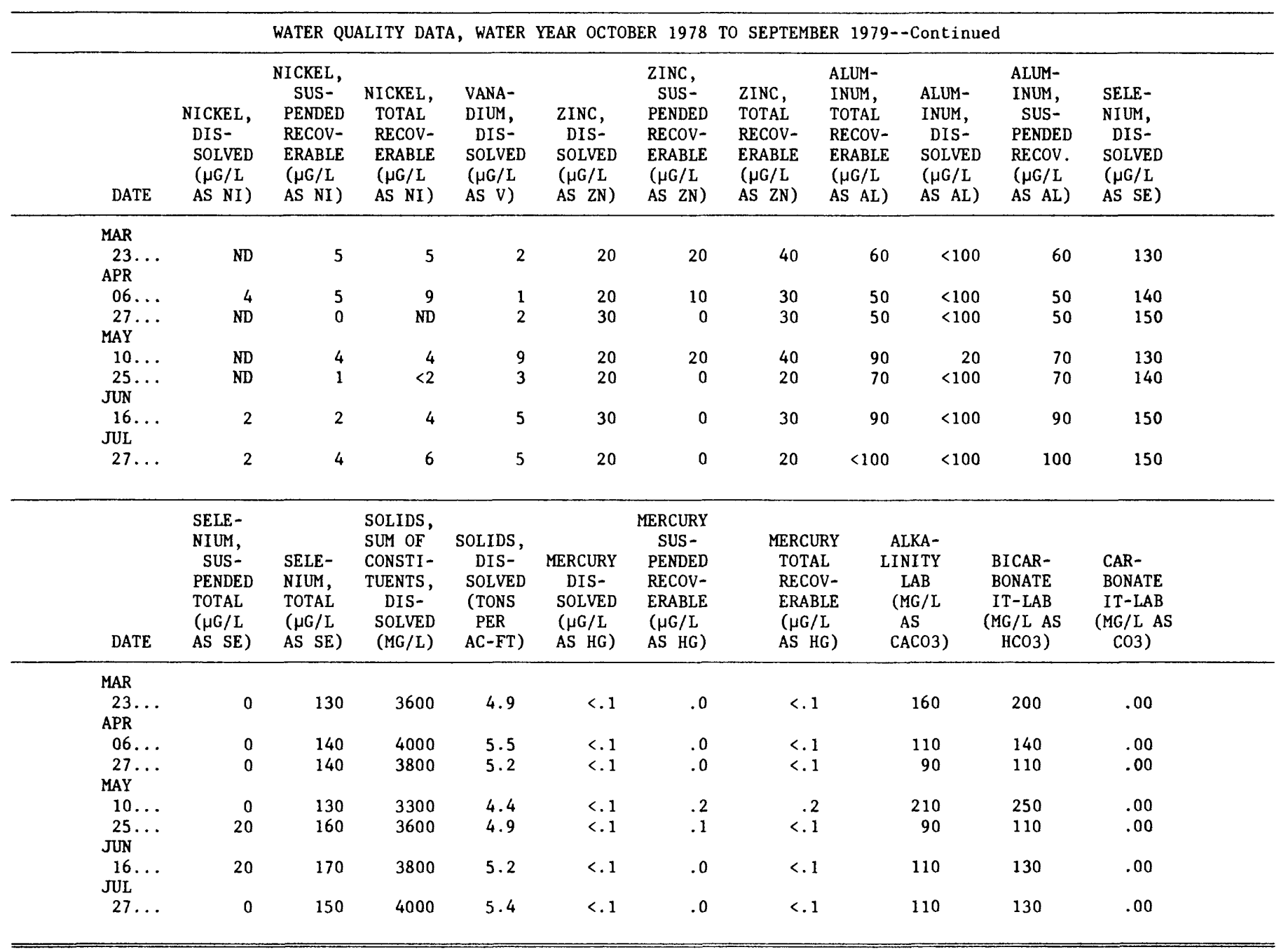


Table 6.--Water-quality data from Lysimeter 3--Continued

WATER QUALITY DATA, WATER YEAR OCTOBER 1979 TO SEPTEMBER 1980

\begin{tabular}{|c|c|c|c|c|c|c|c|c|c|c|c|c|}
\hline DATE & \multicolumn{2}{|c|}{$\begin{array}{l}\text { TEMPER- } \\
\text { ATURE } \\
\left({ }^{\circ} \mathrm{C}\right)\end{array}$} & $\begin{array}{l}\text { SPE- } \\
\text { CIFIC } \\
\text { CON- } \\
\text { DUCT- } \\
\text { ANCE } \\
(\mu S / C M)\end{array}$ & $\begin{array}{c}\text { OXYGEN, } \\
\text { DIS- } \\
\text { SOLVED } \\
(M G / L)\end{array}$ & $\begin{array}{c}\text { PH } \\
\text { (STAND- } \\
\text { ARD } \\
\text { UNITS) }\end{array}$ & $\begin{array}{c}\text { CARBON } \\
\text { DIOXIDE } \\
\text { DIS- } \\
\text { SOLVED } \\
\text { (MG/L } \\
\text { AS CO2) }\end{array}$ & $\begin{array}{c}\text { NITRO- } \\
\text { GEN, } \\
\text { NO2+NO3 } \\
\text { DIS- } \\
\text { SOLVED } \\
\text { (MG/L } \\
\text { AS N) }\end{array}$ & $\begin{array}{l}\text { PHOS- } \\
\text { PHATE, } \\
\text { ORTHO, } \\
\text { DIS- } \\
\text { SOLVED } \\
\text { (MG/L } \\
\text { AS PO4) }\end{array}$ & $\begin{array}{l}\text { PHOS- } \\
\text { PHORUS, } \\
\text { ORTHO, } \\
\text { DIS- } \\
\text { SOLVED } \\
\text { (MG/L } \\
\text { AS P) }\end{array}$ & \multicolumn{3}{|c|}{$\begin{array}{l}\text { HARD- } \\
\text { NESS , } \\
\text { NONCAR- } \\
\text { BONATE } \\
\text { (MG/L AS } \\
\text { CACO3) }\end{array}$} \\
\hline \multicolumn{13}{|l|}{ MAR } \\
\hline $\begin{array}{l}19 . \\
\text { APR }\end{array}$ & \multicolumn{2}{|c|}{--} & 4160 & - & -- & -- & 2.0 & & .050 & 2600 & 2400 & \\
\hline $\begin{array}{r}07 \\
30 \\
\text { MAY }\end{array}$ & & $\begin{array}{r}4.0 \\
12.5\end{array}$ & $\begin{array}{l}4160 \\
4140\end{array}$ & $\begin{array}{l}9.2 \\
8.2\end{array}$ & $\begin{array}{l}7.5 \\
8.4\end{array}$ & $\begin{array}{l}10 \\
1.2\end{array}$ & $\begin{array}{l}.98 \\
.79\end{array}$ & $\begin{array}{l}.09 \\
.03\end{array}$ & $\begin{array}{l}.030 \\
.010\end{array}$ & $\begin{array}{l}3200 \\
3000\end{array}$ & $\begin{array}{l}3000 \\
2900\end{array}$ & \\
\hline $\begin{array}{r}20 \\
\text { JUN }\end{array}$ & & & 3730 & -- & 8.3 & 2.5 & 1.2 & .21 & .070 & 2400 & 2100 & \\
\hline 05 & \multicolumn{2}{|c|}{15.5} & 4190 & -- & 8.4 & 1.0 & .98 & .09 & .030 & 2700 & \multicolumn{2}{|c|}{2600} \\
\hline DATE & $\begin{array}{l}\text { CALCIUM } \\
\text { DIS- } \\
\text { SOLVED } \\
\text { (MG/L } \\
\text { AS CA) }\end{array}$ & $\begin{array}{l}\text { MAGNE- } \\
\text { SIUM, } \\
\text { DIS- } \\
\text { SOLVED } \\
\text { (MG/L } \\
\text { AS MG) }\end{array}$ & $\begin{array}{c}\text { SODIUM, } \\
\text { DIS- } \\
\text { SOLVED } \\
\text { (MG/L } \\
\text { AS NA) }\end{array}$ & $\begin{array}{c}\text { SODIUM } \\
\text { AD- } \\
\text { SORP- } \\
\text { TION } \\
\text { RATIO }\end{array}$ & $\begin{array}{r}\text { PERCENT } \\
\text { SODIUM }\end{array}$ & $\begin{array}{c}\text { SODIUM+ } \\
\text { POTAS- } \\
\text { SIUM } \\
\text { DIS- } \\
\text { SOLVED } \\
\text { (MG/L } \\
\text { AS NA) }\end{array}$ & $\begin{array}{l}\text { POTAS- } \\
\text { SIUM, } \\
\text { DIS- } \\
\text { SOLVED } \\
\text { (MG/L } \\
\text { AS K) }\end{array}$ & $\begin{array}{l}\text { CHLO- } \\
\text { RIDE, } \\
\text { DIS- } \\
\text { SOLVED } \\
\text { (MG/L } \\
\text { AS CL) }\end{array}$ & $\begin{array}{l}\text { SULFATE } \\
\text { DIS- } \\
\text { SOLVED } \\
\text { (MG/L } \\
\text { AS SO4) }\end{array}$ & $\begin{array}{l}\text { FLUO- } \\
\text { RIDE, } \\
\text { DIS- } \\
\text { SOLVED } \\
\text { (MG/L } \\
\text { AS F) }\end{array}$ & $\begin{array}{l}\text { SILICA, } \\
\text { DIS- } \\
\text { SOLVED } \\
\text { (MG/L } \\
\text { AS } \\
\text { SIO2) }\end{array}$ & $\begin{array}{c}\text { ARSENIC } \\
\text { DIS- } \\
\text { SOLVED } \\
(\mu \mathrm{G} / \mathrm{L} \\
\text { AS AS) }\end{array}$ \\
\hline \multicolumn{13}{|l|}{ MAR } \\
\hline $\begin{array}{l}19 \ldots \\
\text { APR }\end{array}$ & 390 & 400 & 81 & .7 & 6 & 120 & 43 & 1.2 & 2700 & .30 & 8.1 & 1 \\
\hline $\begin{array}{l}07 \ldots \\
30 \ldots\end{array}$ & $\begin{array}{l}460 \\
450\end{array}$ & $\begin{array}{l}510 \\
450\end{array}$ & $\begin{array}{l}57 \\
47\end{array}$ & $\begin{array}{l}.4 \\
.4\end{array}$ & $\begin{array}{l}4 \\
3\end{array}$ & 75 & $\begin{array}{l}18 \\
23\end{array}$ & $\begin{array}{l}2.1 \\
3.0\end{array}$ & $\begin{array}{l}3000 \\
2700\end{array}$ & $\begin{array}{l}.30 \\
.40\end{array}$ & \multirow[t]{2}{*}{$\begin{array}{l}5.9 \\
7.0\end{array}$} & $\begin{array}{l}0 \\
1\end{array}$ \\
\hline MAY & \multirow[b]{2}{*}{340} & & & & & \multirow{2}{*}{--} & & & & & & \\
\hline$\underset{\text { JUN }}{20 \ldots}$ & & 380 & 110 & 1 & 9 & & 80 & 2.2 & 2400 & .50 & 11 & 2 \\
\hline $05 \ldots$ & 330 & 460 & 66 & .6 & 5 & -- & 55 & 1.8 & 2800 & .30 & 8.4 & 2 \\
\hline
\end{tabular}


Table 6.--Water-quality data from Lysimeter 3--Continued

WATER QUALITY DATA, WATER YEAR OCTOBER 1979 TO SEPTEMBER 1980--Continued

\begin{tabular}{|c|c|c|c|c|c|c|c|c|c|c|c|}
\hline DATE & $\begin{array}{l}\text { BORON, } \\
\text { DIS- } \\
\text { SOLVED } \\
(\mu G / L \\
\text { AS B) }\end{array}$ & $\begin{array}{c}\text { CADMIUM } \\
\text { DIS- } \\
\text { SOLVED } \\
(\mu G / L \\
\text { AS CD) }\end{array}$ & $\begin{array}{l}\text { COPPER, } \\
\text { DIS- } \\
\text { SOLVED } \\
(\mu G / L \\
\text { AS CU) }\end{array}$ & $\begin{array}{l}\text { IRON, } \\
\text { SUS- } \\
\text { PENDED } \\
\text { RECOV- } \\
\text { ERABLE } \\
(\mu G / L \\
\text { AS FE) }\end{array}$ & $\begin{array}{l}\text { IRON, } \\
\text { TOTAL } \\
\text { RECOV- } \\
\text { ERABLE } \\
(\mu G / L \\
\text { AS FE) }\end{array}$ & $\begin{array}{l}\text { IRON, } \\
\text { DIS- } \\
\text { SOLVED } \\
(\mu G / L \\
\text { AS FE) }\end{array}$ & $\begin{array}{l}\text { LEAD, } \\
\text { DIS- } \\
\text { SOLVED } \\
(\mu G / L \\
\text { AS PB) }\end{array}$ & $\begin{array}{l}\text { MANGA- } \\
\text { NESE, } \\
\text { SUS- } \\
\text { PENDED } \\
\text { RECOV. } \\
\text { ( } \mu G / L \\
\text { AS MN) }\end{array}$ & $\begin{array}{l}\text { MANGA- } \\
\text { NESE, } \\
\text { TOTAL } \\
\text { RECOV- } \\
\text { ERABLE } \\
(\mu G / L \\
\text { AS MN) }\end{array}$ & $\begin{array}{l}\text { MANGA- } \\
\text { NESE, } \\
\text { DIS- } \\
\text { SOLVED } \\
(\mu G / L \\
\text { AS MN) }\end{array}$ & $\begin{array}{l}\text { MOLYB- } \\
\text { DENUM, } \\
\text { DIS- } \\
\text { SOLVED } \\
(\mu G / L \\
\text { AS MO) }\end{array}$ \\
\hline \multicolumn{12}{|l|}{ MAR } \\
\hline$\underset{A P R}{19} \ldots$ & 60 & 0 & 2 & 10 & 60 & 50 & 0 & 0 & 10 & 20 & 3 \\
\hline $07 \ldots$ & 50 & 0 & 1 & 40 & 70 & 30 & 0 & 10 & 20 & 10 & 3 \\
\hline $\begin{array}{l}30 \ldots \\
\text { MAY }\end{array}$ & 40 & 0 & 1 & 70 & 110 & 40 & 0 & 0 & 10 & 10 & 3 \\
\hline JUN & 90 & 0 & 3 & 30 & 60 & 30 & 1 & 0 & 10 & 10 & 3 \\
\hline $05 \ldots$ & 60 & 0 & 3 & 530 & 550 & 20 & 1 & 0 & 20 & 20 & 4 \\
\hline DATE & $\begin{array}{l}\text { NICKEL, } \\
\text { DIS- } \\
\text { SOLVED } \\
(\mu G / L \\
\text { AS NI) }\end{array}$ & $\begin{array}{l}\text { VANA- } \\
\text { DIUM, } \\
\text { DIS- } \\
\text { SOLVED } \\
(\mu G / L \\
\text { AS V) }\end{array}$ & $\begin{array}{l}\text { ZINC, } \\
\text { DIS- } \\
\text { SOLVED } \\
(\mu G / L \\
\text { AS ZN) }\end{array}$ & $\begin{array}{l}\text { ALUM- } \\
\text { INUM, } \\
\text { DIS- } \\
\text { SOLVED } \\
(\mu G / L \\
\text { AS AL) }\end{array}$ & $\begin{array}{l}\text { SELE- } \\
\text { NIUM, } \\
\text { DIS- } \\
\text { SOLVED } \\
(\mu G / L \\
\text { AS SE) }\end{array}$ & $\begin{array}{l}\text { SOLIDS, } \\
\text { SUM OF } \\
\text { CONSTI- } \\
\text { TUENTS, } \\
\text { DIS- } \\
\text { SOLVED } \\
\text { (MG/L) }\end{array}$ & $\begin{array}{l}\text { SOLIDS, } \\
\text { DIS- } \\
\text { SOLVED } \\
\text { (TONS } \\
\text { PER } \\
\text { AC-FT) }\end{array}$ & $\begin{array}{c}\text { MERCURY } \\
\text { DIS- } \\
\text { SOLVED } \\
(\mu G / L \\
\text { AS HG) }\end{array}$ & & $\begin{array}{c}\text { ALKA- } \\
\text { LINITY } \\
\text { LAB } \\
\text { (MG/L } \\
\text { AS } \\
\text { CACO3) }\end{array}$ & $\begin{array}{c}\text { BICAR- } \\
\text { BONATE } \\
\text { IT-LAB } \\
\text { (MG/L AS } \\
\text { HCO3) }\end{array}$ \\
\hline \multicolumn{12}{|l|}{ MAR } \\
\hline $\begin{array}{l}19 \ldots \\
\text { APR }\end{array}$ & 1 & 5 & 20 & 0 & 68 & 3800 & 5.1 & .0 & & 190 & 232 \\
\hline $07 \ldots$ & 3 & 2 & 10 & 20 & 110 & 4200 & 5.7 & .0 & & 170 & 207 \\
\hline $\begin{array}{l}30 \ldots \\
\text { MAY }\end{array}$ & 3 & 2 & 10 & 10 & 110 & 3800 & 5.1 & .0 & & 150 & 183 \\
\hline$\underset{\text { JUN }}{20 \ldots}$ & 3 & 19 & 20 & 20 & 91 & 3500 & 4.8 & .0 & & 260 & 317 \\
\hline $05 \ldots$ & 4 & 10 & 20 & 30 & 100 & 3800 & 5.2 & .0 & & 130 & 159 \\
\hline
\end{tabular}


Table 7.--Water-quality data from Lysimeter 4

WATER QUALITY DATA, WATER YEAR OCTOBER 1977 TO SEPTEMBER 1978

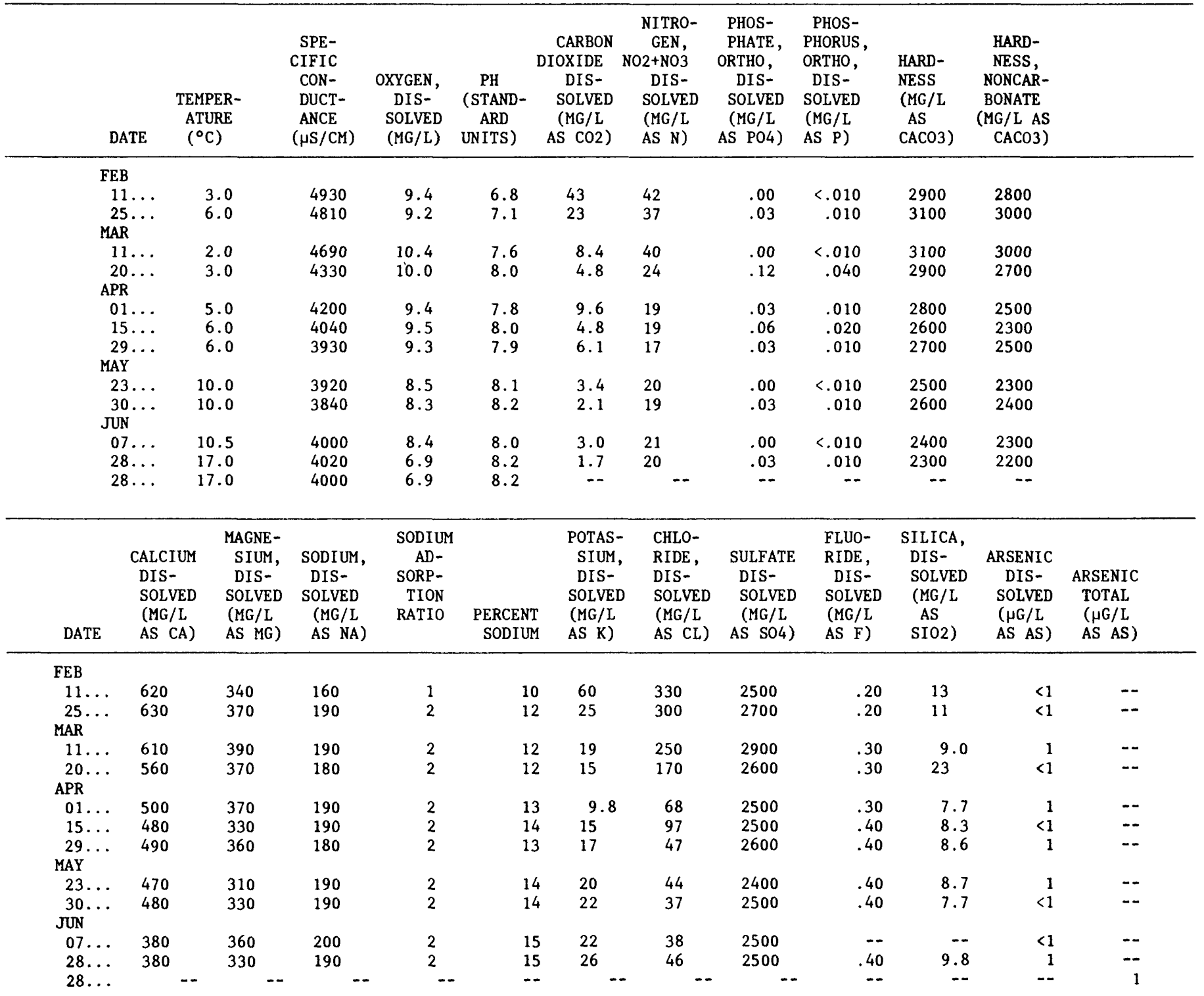


Table 7.-Water-quality data from Lysimeter 4--Continued

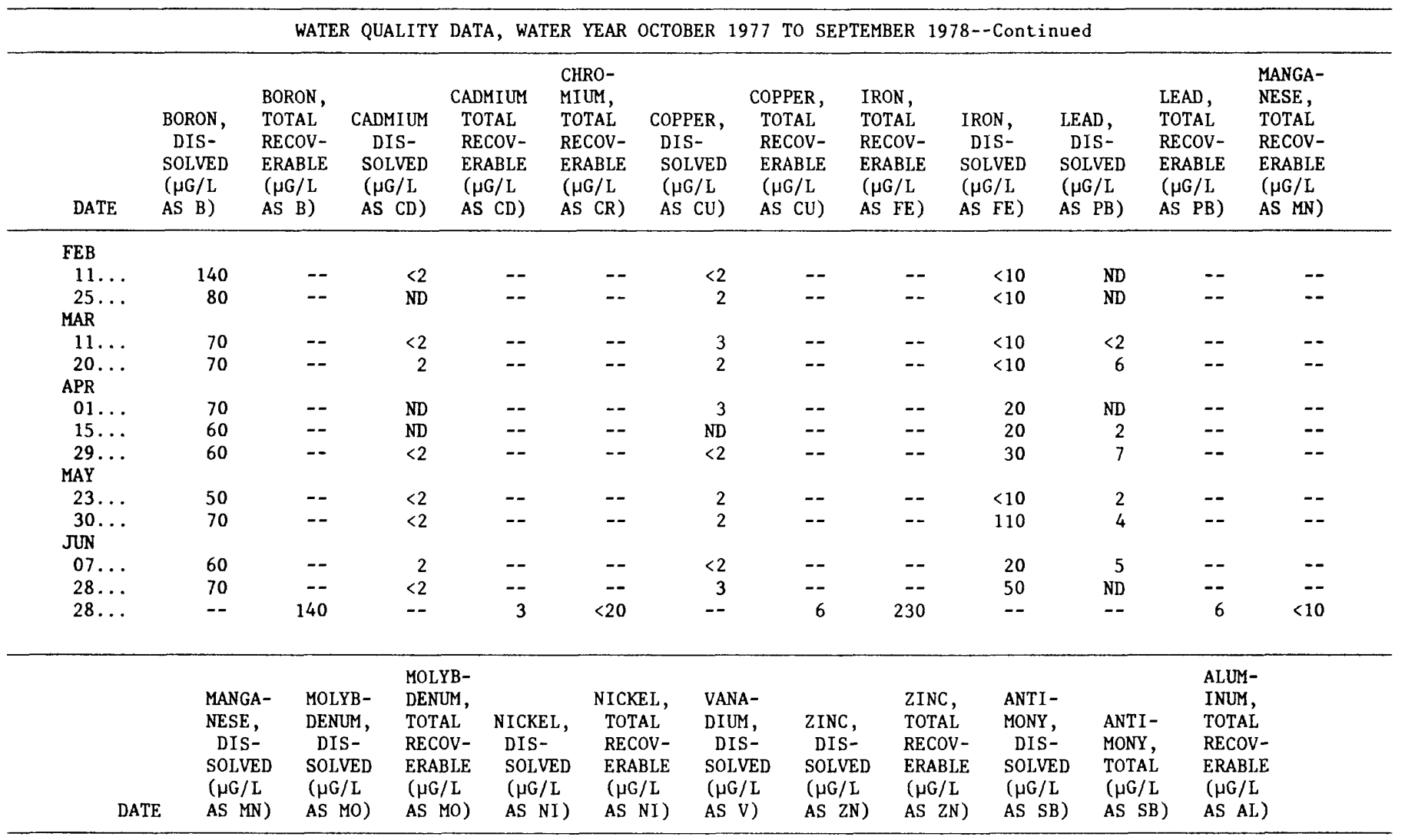

\begin{tabular}{|c|c|c|c|c|c|c|c|c|c|c|c|}
\hline \multicolumn{12}{|l|}{ FEB } \\
\hline $11 \ldots$ & 20 & $<1$ & -- & $<2$ & -- & 4 & 20 & -- & -- & -- & -- \\
\hline $25 \ldots$ & 20 & 3 & -- & 2 & -- & 4 & 20 & -- & -- & -- & -- \\
\hline \multicolumn{12}{|l|}{ MAR } \\
\hline $11 \ldots$ & 20 & 2 & -- & 4 & -- & 3 & 20 & -- & -- & -- & -- \\
\hline $20 \ldots$ & 20 & 3 & -- & 2 & -- & 1 & 20 & -- & $<1$ & -- & -- \\
\hline \multicolumn{12}{|l|}{ APR } \\
\hline $01 \ldots$ & $<10$ & 2 & -- & 4 & -- & 0 & $<20$ & -- & $<1$ & -- & -- \\
\hline $15 \ldots$ & $<10$ & 1 & -- & 4 & -- & 0 & $<20$ & -- & $<1$ & -- & -- \\
\hline $29 \ldots$ & $<10$ & $<1$ & -- & $<2$ & -- & 0 & 20 & -- & $<1$ & -- & -- \\
\hline \multicolumn{12}{|l|}{ MAY } \\
\hline $23 \ldots$ & $<10$ & 3 & -- & 2 & -- & 0 & 20 & -- & $<1$ & -- & -- \\
\hline $30 \ldots$ & $<10$ & 3 & -- & 5 & -- & 0 & 20 & -- & $<1$ & -- & -- \\
\hline \multicolumn{12}{|l|}{ JN } \\
\hline $07 \ldots$ & $<10$ & 3 & -- & 4 & -- & 0 & 20 & -- & $<1$ & -- & -- \\
\hline $28 \ldots$ & 20 & 1 & -- & 5 & -- & 0 & 20 & -- & 3 & -- & -- \\
\hline $28 \ldots$ & - & -- & 7 & - & 8 & -- & - & 20 & -- & 1 & 40 \\
\hline
\end{tabular}


Table 7.--Water-quality data from Lysimeter 4--Continued

\begin{tabular}{|c|c|c|c|c|c|c|c|c|c|c|}
\hline & & WATER QU & LITY DAT & A, WATER & YEAR OCTO & R 1977 TO & PTEMBER 1 & $8--$ Contin & led & \\
\hline DATE & $\begin{array}{l}\text { ALUM- } \\
\text { INUM, } \\
\text { DIS- } \\
\text { SOLVED } \\
(\mu G / L \\
\text { AS AL) }\end{array}$ & $\begin{array}{l}\text { SELE- } \\
\text { NIUM, } \\
\text { DIS- } \\
\text { SOLVED } \\
(\mu G / I \\
\text { AS SE) }\end{array}$ & $\begin{array}{l}\text { SELE- } \\
\text { NIUM, } \\
\text { TOTAL } \\
(\mu G / L \\
\text { AS SE) }\end{array}$ & $\begin{array}{l}\text { SOLIDS, } \\
\text { SUM OF } \\
\text { CONSTI- } \\
\text { TUENTS, } \\
\text { DIS- } \\
\text { SOLVED } \\
\text { (MG/L) }\end{array}$ & $\begin{array}{l}\text { SOLIDS, } \\
\text { DIS- } \\
\text { SOLVED } \\
\text { (TONS } \\
\text { PER } \\
\text { AC-FT) }\end{array}$ & $\begin{array}{c}\text { MERCURY } \\
\text { DIS- } \\
\text { SOLVED } \\
(\mu G / L \\
\text { AS HG) }\end{array}$ & $\begin{array}{c}\text { MERCURY } \\
\text { TOTAL } \\
\text { RECOV- } \\
\text { ERABLE } \\
(\mu G / L \\
\text { AS HG) }\end{array}$ & $\begin{array}{c}\text { ALKA- } \\
\text { LINITY } \\
\text { LAB } \\
\text { (MG/L } \\
\text { AS } \\
\text { CACO3) }\end{array}$ & $\begin{array}{c}\text { BICAR- } \\
\text { BONATE } \\
\text { IT-LAB } \\
\text { (MG/L AS } \\
\text { HCO3) }\end{array}$ & $\begin{array}{c}\text { CAR- } \\
\text { BONATE } \\
\text { IT-LAB } \\
\text { (MG/L AS } \\
\text { CO3) }\end{array}$ \\
\hline \multicolumn{11}{|l|}{ FEB } \\
\hline $11 \ldots$ & 20 & 130 & -- & 4300 & 5.8 & $<.1$ & -- & 140 & 170 & .00 \\
\hline$\underset{\text { MAR }}{25} \cdots$ & $<100$ & 200 & -- & 4500 & 6.1 & $<.1$ & -- & 150 & 180 & .00 \\
\hline $11 \ldots$ & 10 & 75 & -- & 4700 & 6.3 & $<.1$ & -- & 170 & 210 & .00 \\
\hline $20 \ldots$ & 20 & 150 & -- & 4200 & 5.7 & $<.1$ & -- & 250 & 300 & .00 \\
\hline \multicolumn{11}{|l|}{ APR } \\
\hline $01 \ldots$ & $<100$ & 83 & -- & 3900 & 5.3 & $<.1$ & - & 310 & 380 & .00 \\
\hline $15 \ldots$ & $<100$ & 50 & -- & 3900 & 5.2 & $<.1$ & - & 250 & 300 & .00 \\
\hline $29 \ldots$ & $<100$ & 44 & -- & 3900 & 5.3 & $<.1$ & - & 220 & 270 & .00 \\
\hline \multicolumn{11}{|l|}{ MAY } \\
\hline $23 \ldots$ & $<100$ & 46 & -- & 3700 & 5.0 & $<.1$ & - & 200 & 240 & .00 \\
\hline $30 \ldots$ & 20 & 42 & -- & 3800 & 5.1 & $<.1$ & 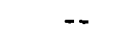 & 170 & 210 & .00 \\
\hline \multicolumn{11}{|l|}{ JUN } \\
\hline $07 \ldots$ & 0 & 30 & -- & 3200 & 5.0 & $<.1$ & -- & 160 & 190 & .00 \\
\hline $28 \ldots$ & $<100$ & 35 & -- & 3700 & 5.0 & $<.1$ & -- & 140 & 170 & .00 \\
\hline $28 \ldots$ & -. & -- & 33 & -- & -- & -- & $<.1$ & -. & -- & -. \\
\hline
\end{tabular}

WATER QUALITY DATA, WATER YEAR OCTOBER 1978 TO SEPTEMBER 1979

\begin{tabular}{|c|c|c|c|c|c|c|c|c|c|}
\hline DATE & $\begin{array}{l}\text { TEMPER- } \\
\text { ATURE } \\
\left({ }^{\circ} \mathrm{C}\right)\end{array}$ & $\begin{array}{l}\text { SPE- } \\
\text { CIFIC } \\
\text { CON- } \\
\text { DUCT- } \\
\text { ANCE } \\
(\mu \mathrm{S} / \mathrm{CM})\end{array}$ & $\begin{array}{c}\text { OXYGEN, } \\
\text { DIS- } \\
\text { SOLVED } \\
(M G / L)\end{array}$ & $\begin{array}{c}\mathrm{PH} \\
\text { (STAND- } \\
\text { ARD } \\
\text { UNITS) }\end{array}$ & $\begin{array}{c}\text { CARBON } \\
\text { DIOXIDE } \\
\text { DIS- } \\
\text { SOLVED } \\
\text { (MG/L } \\
\text { AS CO2) }\end{array}$ & $\begin{array}{c}\text { NITRO- } \\
\text { GEN, } \\
\text { NO2+NO3 } \\
\text { DIS- } \\
\text { SOLVED } \\
\text { (MG/L } \\
\text { AS N) }\end{array}$ & $\begin{array}{l}\text { PHOS- } \\
\text { PHATE, } \\
\text { ORTHO, } \\
\text { DIS- } \\
\text { SOLVED } \\
\text { (MG/L } \\
\text { AS PO4) }\end{array}$ & $\begin{array}{l}\text { PHOS- } \\
\text { PHORUS, } \\
\text { ORTHO, } \\
\text { DIS- } \\
\text { SOLVED } \\
\text { (MG/L } \\
\text { AS P) }\end{array}$ & $\begin{array}{l}\text { HARD- } \\
\text { NESS } \\
\text { (MG/L } \\
\text { AS } \\
\text { CACO3) }\end{array}$ \\
\hline $\begin{array}{r}\text { MAY } \\
25 \ldots\end{array}$ & 15.0 & 3500 & 7.0 & 8.3 & 2.5 & 7.8 & .06 & .020 & 1800 \\
\hline
\end{tabular}


Table 7.--Water-quality data from Lysimeter 4--Continued

WATER QUALITY DATA, WATER YEAR OCTOBER 1978 TO SEPTEMBER 1979--Continued

\begin{tabular}{|c|c|c|c|c|c|c|c|c|c|c|c|}
\hline DATE & $\begin{array}{l}\text { HARD- } \\
\text { NESS } \\
\text { NONCAR- } \\
\text { BONATE } \\
\text { (MG/L AS } \\
\text { CACO3) }\end{array}$ & $\begin{array}{l}\text { CALCIUM } \\
\text { DIS- } \\
\text { SOLVED } \\
\text { (MG/L } \\
\text { AS CA) }\end{array}$ & $\begin{array}{l}\text { MAGNE- } \\
\text { SIUM, } \\
\text { DIS- } \\
\text { SOLVED } \\
\text { (MG/L } \\
\text { AS MG) }\end{array}$ & $\begin{array}{l}\text { SODIUM, } \\
\text { DIS- } \\
\text { SOLVED } \\
\text { (MG/L } \\
\text { AS NA) }\end{array}$ & $\begin{array}{c}\text { SODIUM } \\
\text { AD- } \\
\text { SORP- } \\
\text { TION } \\
\text { RATIO }\end{array}$ & $\begin{array}{r} \\
\text { PERCENT } \\
\text { SODIUM }\end{array}$ & $\begin{array}{c}\text { SODIUM+ } \\
\text { POTAS- } \\
\text { SIUM } \\
\text { DIS- } \\
\text { SOLVED } \\
\text { (MG/L } \\
\text { AS NA) }\end{array}$ & $\begin{array}{l}\text { CHLO- } \\
\text { RIDE, } \\
\text { DIS- } \\
\text { SOLVED } \\
\text { (MG/L } \\
\text { AS CL) }\end{array}$ & $\begin{array}{l}\text { SULFATE } \\
\text { DIS- } \\
\text { SOLVED } \\
\text { (MG/L } \\
\text { AS SO4) }\end{array}$ & $\begin{array}{l}\text { FLUO- } \\
\text { RIDE, } \\
\text { DIS- } \\
\text { SOLVED } \\
\text { (MG/L } \\
\text { AS F) }\end{array}$ & $\begin{array}{l}\text { SILICA, } \\
\text { DIS- } \\
\text { SOLVED } \\
\text { (MG/L } \\
\text { AS } \\
\text { SIO2) }\end{array}$ \\
\hline $\begin{array}{l}\text { MAY } \\
25 \ldots\end{array}$ & 1600 & 300 & 260 & 280 & 3 & 39 & 410 & 18 & 2200 & .50 & 9.0 \\
\hline DATE & $\begin{array}{c}\text { ARSENIC } \\
\text { DIS- } \\
\text { SOLVED } \\
(\mu G / L \\
\text { AS AS) }\end{array}$ & $\begin{array}{c}\text { ARSENIC } \\
\text { TOTAL } \\
\text { ( } \mu G / L \\
\text { AS AS) }\end{array}$ & $\begin{array}{l}\text { BORON, } \\
\text { DIS- } \\
\text { SOLVED } \\
\text { ( } \mu G / L \\
\text { AS B) }\end{array}$ & $\begin{array}{c}\text { CADMIUM } \\
\text { DIS- } \\
\text { SOLVED } \\
(\mu G / L \\
\text { AS CD) }\end{array}$ & $\begin{array}{c}\text { CADMIUM } \\
\text { SUS- } \\
\text { PENDED } \\
\text { RECOV- } \\
\text { ERABLE } \\
(\mu G / L \\
\text { AS CD) }\end{array}$ & $\begin{array}{l}\text { CADMIUM } \\
\text { TOTAL } \\
\text { RECOV- } \\
\text { ERABLE } \\
(\mu G / L \\
\text { AS CD) }\end{array}$ & $\begin{array}{l}\text { COPPER, } \\
\text { DIS- } \\
\text { SOLVED } \\
(\mu G / L \\
\text { AS CU) }\end{array}$ & $\begin{array}{l}\text { COPPER, } \\
\text { SUS- } \\
\text { PENDED } \\
\text { RECOV- } \\
\text { ERABLE } \\
(\mu G / L \\
\text { AS CU) }\end{array}$ & $\begin{array}{l}\text { COPPER, } \\
\text { TOTAL } \\
\text { RECOV- } \\
\text { ERABLE } \\
(\mu G / L \\
\text { AS CU) }\end{array}$ & $\begin{array}{l}\text { IRON, } \\
\text { SUS- } \\
\text { PENDED } \\
\text { RECOV- } \\
\text { ERABLE } \\
(\mu G / L \\
\text { AS FE) }\end{array}$ & $\begin{array}{l}\text { IRON, } \\
\text { TOTAL } \\
\text { RECOV- } \\
\text { ERABLE } \\
\text { ( } \mu \text { G/L } \\
\text { AS FE) }\end{array}$ \\
\hline
\end{tabular}

\begin{tabular}{|c|c|c|c|c|c|c|c|c|c|c|c|}
\hline $\begin{array}{l}\text { MAY } \\
25 \ldots\end{array}$ & 1 & 3 & 70 & ND & 0 & ND & 2 & 5 & 7 & 30 & 40 \\
\hline DATE & $\begin{array}{l}\text { IRON, } \\
\text { DIS- } \\
\text { SOLVED } \\
(\mu G / L \\
\text { AS FE) }\end{array}$ & $\begin{array}{l}\text { LEAD, } \\
\text { DIS- } \\
\text { SOLVED } \\
(\mu G / L \\
\text { AS PB) }\end{array}$ & $\begin{array}{l}\text { LEAD, } \\
\text { SUS- } \\
\text { PENDED } \\
\text { RECOV- } \\
\text { ERABLE } \\
\text { ( } \mu \text { G / L } \\
\text { AS PB) }\end{array}$ & $\begin{array}{l}\text { LEAD, } \\
\text { TOTAL } \\
\text { RECOV- } \\
\text { ERABLE } \\
(\mu G / \mathrm{L} \\
\text { AS PB) }\end{array}$ & $\begin{array}{l}\text { MANGA- } \\
\text { NESE, } \\
\text { SUS- } \\
\text { PENDED } \\
\text { RECOV. } \\
(\mu G / L \\
\text { AS MN) }\end{array}$ & $\begin{array}{l}\text { MANGA- } \\
\text { NESE, } \\
\text { TOTAL } \\
\text { RECOV- } \\
\text { ERABLE } \\
(\mu G / L \\
\text { AS MN) }\end{array}$ & $\begin{array}{l}\text { MANGA- } \\
\text { NESE, } \\
\text { DIS- } \\
\text { SOLVED } \\
(\mu G / L \\
\text { AS MN) }\end{array}$ & $\begin{array}{l}\text { MOLYB- } \\
\text { DENUM, } \\
\text { DIS- } \\
\text { SOLVED } \\
(\mu G / L \\
\text { AS MO) }\end{array}$ & $\begin{array}{l}\text { MOLYB- } \\
\text { DENUM, } \\
\text { SUS- } \\
\text { PENDED } \\
\text { RECOV. } \\
(\mu G / L \\
\text { AS MO) }\end{array}$ & $\begin{array}{l}\text { MOLYB- } \\
\text { DENUM, } \\
\text { TOTAL } \\
\text { RECOV- } \\
\text { ERABLE } \\
(\mu G / L \\
\text { AS MO) }\end{array}$ & $\begin{array}{l}\text { NICKEL, } \\
\text { DIS- } \\
\text { SOLVED } \\
\text { ( } \mu G / L \\
\text { AS NI) }\end{array}$ \\
\hline
\end{tabular}

\begin{tabular}{|c|c|c|c|c|c|c|c|c|c|c|c|}
\hline $\begin{array}{l}\text { MAY } \\
25 \ldots\end{array}$ & $<10$ & ND & 4 & 4 & 0 & $<10$ & $<10$ & 4 & 2 & 6 & $<2$ \\
\hline DATE & $\begin{array}{c}\text { NICKEL, } \\
\text { SUS- } \\
\text { PENDED } \\
\text { RECOV- } \\
\text { ERABLE } \\
(\mu G / L \\
\text { AS NI) }\end{array}$ & $\begin{array}{c}\text { NICKEL, } \\
\text { TOTAL } \\
\text { RECOV- } \\
\text { ERABLE } \\
\text { ( } \mu \mathrm{G} / \mathrm{L} \\
\text { AS NI) }\end{array}$ & $\begin{array}{l}\text { VANA- } \\
\text { DIUM, } \\
\text { DIS- } \\
\text { SOLVED } \\
(\mu G / L \\
\text { AS V) }\end{array}$ & $\begin{array}{l}\text { ZINC, } \\
\text { DIS- } \\
\text { SOLVED } \\
(\mu G / L \\
\text { AS } Z N)\end{array}$ & $\begin{array}{l}\text { ZINC, } \\
\text { SUS- } \\
\text { PENDED } \\
\text { RECOV- } \\
\text { ERABLE } \\
(\mu G / L \\
\text { AS ZN) }\end{array}$ & $\begin{array}{l}\text { ZINC, } \\
\text { TOTAL } \\
\text { RECOV- } \\
\text { ERABLE } \\
(\mu G / L \\
\text { AS ZN) }\end{array}$ & $\begin{array}{l}\text { ALUM- } \\
\text { INUM, } \\
\text { TOTAL } \\
\text { RECOV- } \\
\text { ERABLE } \\
(\mu G / L \\
\text { AS AL) }\end{array}$ & $\begin{array}{l}\text { ALUM- } \\
\text { INUM, } \\
\text { DIS- } \\
\text { SOLVED } \\
\text { ( } \mu G / L \\
\text { AS AL) }\end{array}$ & $\begin{array}{l}\text { ALUM- } \\
\text { INUM, } \\
\text { SUS- } \\
\text { PENDED } \\
\text { RECOV. } \\
(\mu G / L \\
\text { AS AL) }\end{array}$ & $\begin{array}{l}\text { SELE- } \\
\text { NIUM, } \\
\text { DIS- } \\
\text { SOLVED } \\
(\mu G / L \\
\text { AS SE) }\end{array}$ & $\begin{array}{l}\text { SELE- } \\
\text { NIUM, } \\
\text { SUS- } \\
\text { PENDED } \\
\text { TOTAL } \\
(\mu G / L \\
\text { AS SE) }\end{array}$ \\
\hline
\end{tabular}

MAY

$25 \ldots$

120

20

0

$20 \quad 7$

$70<100$

$70 \quad 170$

10 
Table 7.--Water-quality data from Lysimeter 4--Continued

\begin{tabular}{|c|c|c|c|c|c|c|c|c|c|c|c|c|c|}
\hline \multirow{2}{*}{\multicolumn{3}{|c|}{$\begin{array}{l}\text { DATE } \\
\text { MAY } \\
25 \ldots\end{array}$}} & \multirow{2}{*}{$\begin{array}{l}\text { SELE- } \\
\text { NIUM, } \\
\text { TOTAL } \\
(\mu G / L \\
\text { AS SE) } \\
\\
180\end{array}$} & $\begin{array}{c}\text { SOLIDS, } \\
\text { SUM OF } \\
\text { CONSTI- } \\
\text { TUENTS, } \\
\text { DIS- } \\
\text { SOLVED } \\
\text { (MG } / L)\end{array}$ & $\begin{array}{c}\text { SOLIDS, } \\
\text { DIS- } \\
\text { SOLVED } \\
\text { (TONS } \\
\text { PER } \\
\text { AC-FT) }\end{array}$ & $\begin{array}{c}\text { MERCURY } \\
\text { DIS- } \\
\text { SOLVED } \\
(\mu G / L \\
\text { AS HG) }\end{array}$ & $\begin{array}{l}\text { MERCURY } \\
\text { SUS- } \\
\text { PENDED } \\
\text { RECOV- } \\
\text { ERABLE } \\
\text { ( } \mu \text { G/L } \\
\text { AS HG) }\end{array}$ & \multicolumn{2}{|c|}{$\begin{array}{l}\text { MERCURY } \\
\text { TOTAL } \\
\text { RECOV- } \\
\text { ERABLE } \\
(\mu G / L \\
\text { AS HG) }\end{array}$} & $\begin{array}{c}\text { ALKA- } \\
\text { LINITY } \\
\text { LAB } \\
\text { (MG/L } \\
\text { AS } \\
\text { CACO3) }\end{array}$ & $\begin{array}{l}\text { BICAR- } \\
\text { BONATE } \\
\text { IT-LAB } \\
\text { (MG/L AS } \\
\text { HCO3) }\end{array}$ & $\begin{array}{c}\text { CAR- } \\
\text { BONATE } \\
\text { IT-LAB } \\
(\mathrm{MG} / \mathrm{L} \text { AS } \\
\text { CO3) }\end{array}$ & \\
\hline & & & & 3200 & 4 & 1 & 0 & $<$ & & 230 & 280 & 00 & \\
\hline \multicolumn{14}{|c|}{ WATER QUALITY DATA, WATER YEAR OCTOBER 1979 TO SEPTEMBER 1980} \\
\hline \multicolumn{4}{|c|}{$\begin{array}{l}\text { TEMPER- } \\
\text { ATURE } \\
\left({ }^{\circ} \mathrm{C}\right)\end{array}$} & $\begin{array}{l}\text { SPE- } \\
\text { CIFIC } \\
\text { CON- } \\
\text { DUCT- } \\
\text { ANCE } \\
(\mu S / C M)\end{array}$ & $\begin{array}{c}\text { OXYGEN, } \\
\text { DIS- } \\
\text { SOLVED } \\
\text { (MG/L) }\end{array}$ & $\begin{array}{l}\text { PH } \\
\text { (STAND- } \\
\text { ARD } \\
\text { UNITS) }\end{array}$ & $\begin{array}{l}\text { CARBON } \\
\text { DIOXIDE } \\
\text { DIS- } \\
\text { SOLVED } \\
\text { (MG/I } \\
\text { AS CO2) }\end{array}$ & $\begin{array}{l}\text { NITRO- } \\
\text { GEN, } \\
\text { NO2+NO3 } \\
\text { DIS- } \\
\text { SOLVED } \\
\text { (MG/L } \\
\text { AS N) }\end{array}$ & $\begin{array}{l}\text { PHOS- } \\
\text { PHATE, } \\
\text { ORTHO, } \\
\text { DIS- } \\
\text { SOLVED } \\
\text { (MG/L } \\
\text { AS PO4) }\end{array}$ & $\begin{array}{l}\text { PHOS- } \\
\text { PHORUS, } \\
\text { ORTHO, } \\
\text { DIS- } \\
\text { SOLVED } \\
\text { (MG/L } \\
\text { AS P) }\end{array}$ & $\begin{array}{l}\text { HARD- } \\
\text { NESS } \\
(\mathrm{MG} / \mathrm{L} \\
\text { AS } \\
\text { CACO3) }\end{array}$ & $\begin{array}{l}\text { HARD- } \\
\text { NESS, } \\
\text { NONCAR- } \\
\text { BONATE } \\
\text { (MG/L AS } \\
\text { CACO3) }\end{array}$ & \\
\hline \multicolumn{2}{|c|}{$\begin{array}{l}\text { APR } \\
07 \ldots \\
30 \ldots \\
\text { JUN } \\
05 \ldots\end{array}$} & & $\begin{array}{l}.0 \\
.0\end{array}$ & $\begin{array}{l}4500 \\
4400 \\
3480\end{array}$ & $\begin{array}{r}9.4 \\
8.2 \\
-.\end{array}$ & $\begin{array}{l}7.3 \\
8.3 \\
8.5\end{array}$ & $\begin{array}{l}22 \\
1.9 \\
\\
2.1\end{array}$ & $\begin{array}{r}.65 \\
.47 \\
\\
1.8\end{array}$ & $\begin{array}{l}.15 \\
.03 \\
.21\end{array}$ & $\begin{array}{l}.050 \\
.010 \\
.070\end{array}$ & $\begin{array}{l}2900 \\
2800 \\
1600\end{array}$ & $\begin{array}{l}2700 \\
2600 \\
1300\end{array}$ & \\
\hline DATE & $\begin{array}{l}\text { CALC } \\
\text { DIS } \\
\text { SOL } \\
\text { (MG } \\
\text { AS }\end{array}$ & $\begin{array}{l}\text { IUM } \\
- \\
\text { VED } \\
\text { /L } \\
\text { CA) }\end{array}$ & $\begin{array}{l}\text { MAGNE- } \\
\text { SIUM, } \\
\text { DIS- } \\
\text { SOLVED } \\
\text { (MG/L } \\
\text { AS MG) }\end{array}$ & $\begin{array}{l}\text { SODIUM, } \\
\text { DIS- } \\
\text { SOLVED } \\
\text { (MG } / L \\
\text { AS NA) }\end{array}$ & $\begin{array}{l}\text { SODIUM } \\
\text { AD- } \\
\text { SORP- } \\
\text { TION } \\
\text { RATIO }\end{array}$ & $\begin{array}{r}\text { PERCENT } \\
\text { SODIUM }\end{array}$ & $\begin{array}{c}\text { SODIUM+ } \\
\text { POTAS- } \\
\text { SIUM } \\
\text { DIS- } \\
\text { SOLVED } \\
\text { (MG/L } \\
\text { AS NA) }\end{array}$ & $\begin{array}{l}\text { POTAS- } \\
\text { SIUM, } \\
\text { DIS- } \\
\text { SOLVED } \\
\text { (MG/I } \\
\text { AS K) }\end{array}$ & $\begin{array}{l}\text { CHLO- } \\
\text { RIDE, } \\
\text { DIS- } \\
\text { SOLVED } \\
\text { (MG/L } \\
\text { AS CL) }\end{array}$ & $\begin{array}{c}\text { SULFATE } \\
\text { DIS- } \\
\text { SOLVED } \\
(M G / L \\
\text { AS SO4) }\end{array}$ & $\begin{array}{l}\text { FLUO- } \\
\text { RIDE, } \\
\text { DIS- } \\
\text { SOLVED } \\
\text { (MG/L } \\
\text { AS F) }\end{array}$ & $\begin{array}{l}\text { SILICA, } \\
\text { DIS- } \\
\text { SOLVED } \\
\text { (MG/L } \\
\text { AS } \\
\text { SIO2) }\end{array}$ & $\begin{array}{c}\text { ARSENIC } \\
\text { DIS- } \\
\text { SOLVED } \\
(\mu G / L \\
\text { AS AS) }\end{array}$ \\
\hline \multicolumn{14}{|l|}{ APR } \\
\hline $\begin{array}{l}07 \ldots \\
30 \ldots \\
\text { JUN }\end{array}$ & $\begin{array}{l}470 \\
470\end{array}$ & & $\begin{array}{l}410 \\
400\end{array}$ & $\begin{array}{l}230 \\
190\end{array}$ & $\begin{array}{l}2 \\
2\end{array}$ & $\begin{array}{l}15 \\
13\end{array}$ & 270 & $\begin{array}{l}44 \\
36\end{array}$ & $\begin{array}{r}10 \\
280\end{array}$ & $\begin{array}{l}3000 \\
2700\end{array}$ & $\begin{array}{l}.30 \\
.40\end{array}$ & $\begin{array}{l}8.1 \\
8.9\end{array}$ & $\begin{array}{l}0 \\
1\end{array}$ \\
\hline $05 \ldots$ & 230 & & 250 & 240 & 3 & 23 & -- & 110 & 8.6 & 1900 & .40 & 13 & 3 \\
\hline
\end{tabular}


Table 7.--Water-quality data from Lysimeter 4--Continued

WATER QUALITY DATA, WATER YEAR OCTOBER 1979 TO SEPTEMBER 1980

\begin{tabular}{|c|c|c|c|c|c|c|c|c|c|c|c|}
\hline DATE & $\begin{array}{l}\text { BORON, } \\
\text { DIS- } \\
\text { SOLVED } \\
(\mu G / L \\
\text { AS B) }\end{array}$ & $\begin{array}{c}\text { CADMIUM } \\
\text { DIS- } \\
\text { SOLVED } \\
(\mu G / L \\
\text { AS CD) }\end{array}$ & $\begin{array}{l}\text { COPPER, } \\
\text { DIS- } \\
\text { SOLVED } \\
(\mu G / L \\
\text { AS CU) }\end{array}$ & $\begin{array}{l}\text { IRON, } \\
\text { SUS- } \\
\text { PENDED } \\
\text { RECOV- } \\
\text { ERABLE } \\
(\mu G / L \\
\text { AS FE) }\end{array}$ & $\begin{array}{l}\text { IRON, } \\
\text { TOTAL } \\
\text { RECOV- } \\
\text { ERABLE } \\
(\mu \mathrm{G} / \mathrm{L} \\
\text { AS FE) }\end{array}$ & $\begin{array}{l}\text { IRON, } \\
\text { DIS- } \\
\text { SOLVED } \\
(\mu G / L \\
\text { AS FE) }\end{array}$ & $\begin{array}{l}\text { LEAD, } \\
\text { DIS- } \\
\text { SOLVED } \\
(\mu G / L \\
\text { AS PB) }\end{array}$ & $\begin{array}{l}\text { MANGA- } \\
\text { NESE, } \\
\text { SUS- } \\
\text { PENDED } \\
\text { RECOV. } \\
(\mu G / L \\
\text { AS MN) }\end{array}$ & $\begin{array}{l}\text { MANGA- } \\
\text { NESE, } \\
\text { TOTAL } \\
\text { RECOV- } \\
\text { ERABLE } \\
(\mu G / L \\
\text { AS MN) }\end{array}$ & $\begin{array}{l}\text { MANGA- } \\
\text { NESE, } \\
\text { DIS- } \\
\text { SOLVED } \\
(\mu G / L \\
\text { AS MN) }\end{array}$ & $\begin{array}{l}\text { MOLYB- } \\
\text { DENUM, } \\
\text { DIS- } \\
\text { SOLVED } \\
(\mu \mathrm{G} / \mathrm{L} \\
\text { AS MO) }\end{array}$ \\
\hline \multicolumn{12}{|l|}{ APR } \\
\hline $07 \ldots$ & 70 & 0 & 1 & 30 & 50 & 20 & 0 & 10 & 20 & 10 & 2 \\
\hline $30 \ldots$ & 60 & 0 & 1 & 100 & 140 & 40 & 0 & 10 & 20 & 10 & 2 \\
\hline \multicolumn{12}{|l|}{ JUN } \\
\hline $05 \ldots$ & 100 & 0 & 3 & 170 & 190 & 20 & 5 & 0 & 10 & 10 & 3 \\
\hline DATE & $\begin{array}{l}\text { NICKEL, } \\
\text { DIS- } \\
\text { SOLVED } \\
(\mu \mathrm{G} / \mathrm{L} \\
\text { AS NI) }\end{array}$ & $\begin{array}{l}\text { VANA- } \\
\text { DIUM, } \\
\text { DIS- } \\
\text { SOLVED } \\
(\mu G / L \\
\text { AS V) }\end{array}$ & $\begin{array}{l}\text { ZINC, } \\
\text { DIS- } \\
\text { SOLVED } \\
(\mu G / L \\
\text { AS ZN) }\end{array}$ & $\begin{array}{l}\text { ALUM- } \\
\text { INUM, } \\
\text { DIS- } \\
\text { SOLVED } \\
(\mu \mathrm{G} / \mathrm{L} \\
\text { AS AL) }\end{array}$ & $\begin{array}{l}\text { SELE- } \\
\text { NIUM, } \\
\text { DIS- } \\
\text { SOLVED } \\
(\mu G / L \\
\text { AS SE) }\end{array}$ & $\begin{array}{c}\text { SOLIDS, } \\
\text { SUM OF } \\
\text { CONSTI- } \\
\text { TUENTS, } \\
\text { DIS- } \\
\text { SOLVED } \\
(\mathrm{MG} / \mathrm{L})\end{array}$ & $\begin{array}{l}\text { SOLIDS, } \\
\text { DIS- } \\
\text { SOLVED } \\
\text { (TONS } \\
\text { PER } \\
\text { AC-FT) }\end{array}$ & $\begin{array}{c}\text { MERCURY } \\
\text { DIS- } \\
\text { SOLVED } \\
\text { ( } \mu \mathrm{G} / \mathrm{L} \\
\text { AS HG) }\end{array}$ & $\begin{array}{r}\mathrm{AI} \\
\mathrm{LI} \\
\mathrm{I} \\
\mathrm{C} \\
\mathrm{CA}\end{array}$ & $\begin{array}{l}\text { KA- } \\
\text { ITY } \\
\text { AB } \\
\text { G/L } \\
\text { S } \\
\text { CO3) }\end{array}$ & $\begin{array}{c}\text { BICAR- } \\
\text { BONATE } \\
\text { IT-LAB } \\
\text { (MG/L AS } \\
\text { HCO3) }\end{array}$ \\
\hline \multicolumn{12}{|l|}{ APR } \\
\hline $07 \ldots$ & 6 & 1 & 10 & 30 & 220 & 4300 & 5.9 & .0 & & 30 & 280 \\
\hline \multicolumn{11}{|l|}{ JUN } & 243 \\
\hline $05 \ldots$ & 4 & 24 & 10 & 30 & 100 & 3000 & 4.0 & .0 & & 10 & 378 \\
\hline
\end{tabular}


Table 8.--Water-quality data from Lysimeter 5

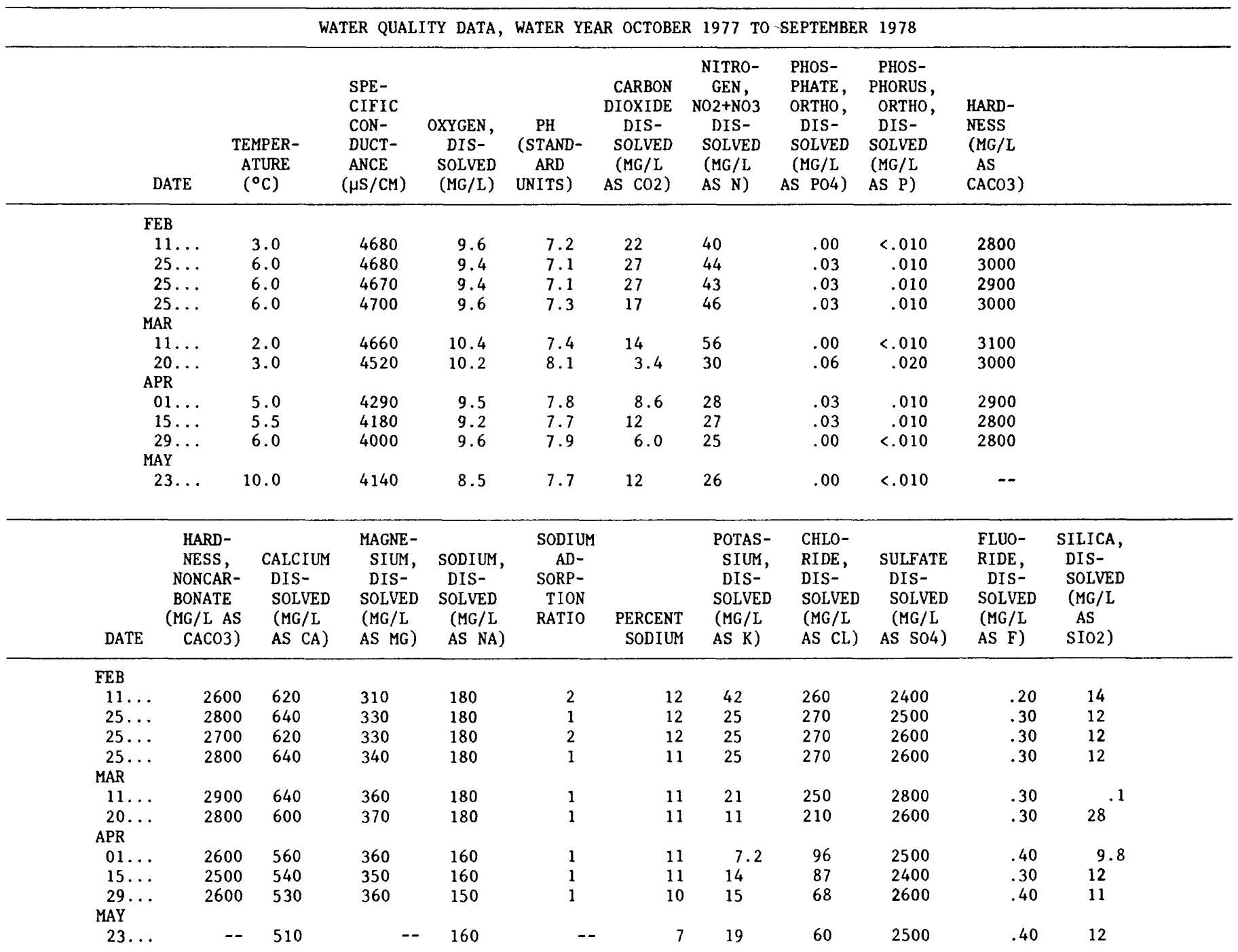


Table 8.--Water-quality data from Lysimeter 5--Continued

WATER QUALITY DATA, WATER YEAR OCTOBER 1977 TO SEPTEMBER 1978--Continued

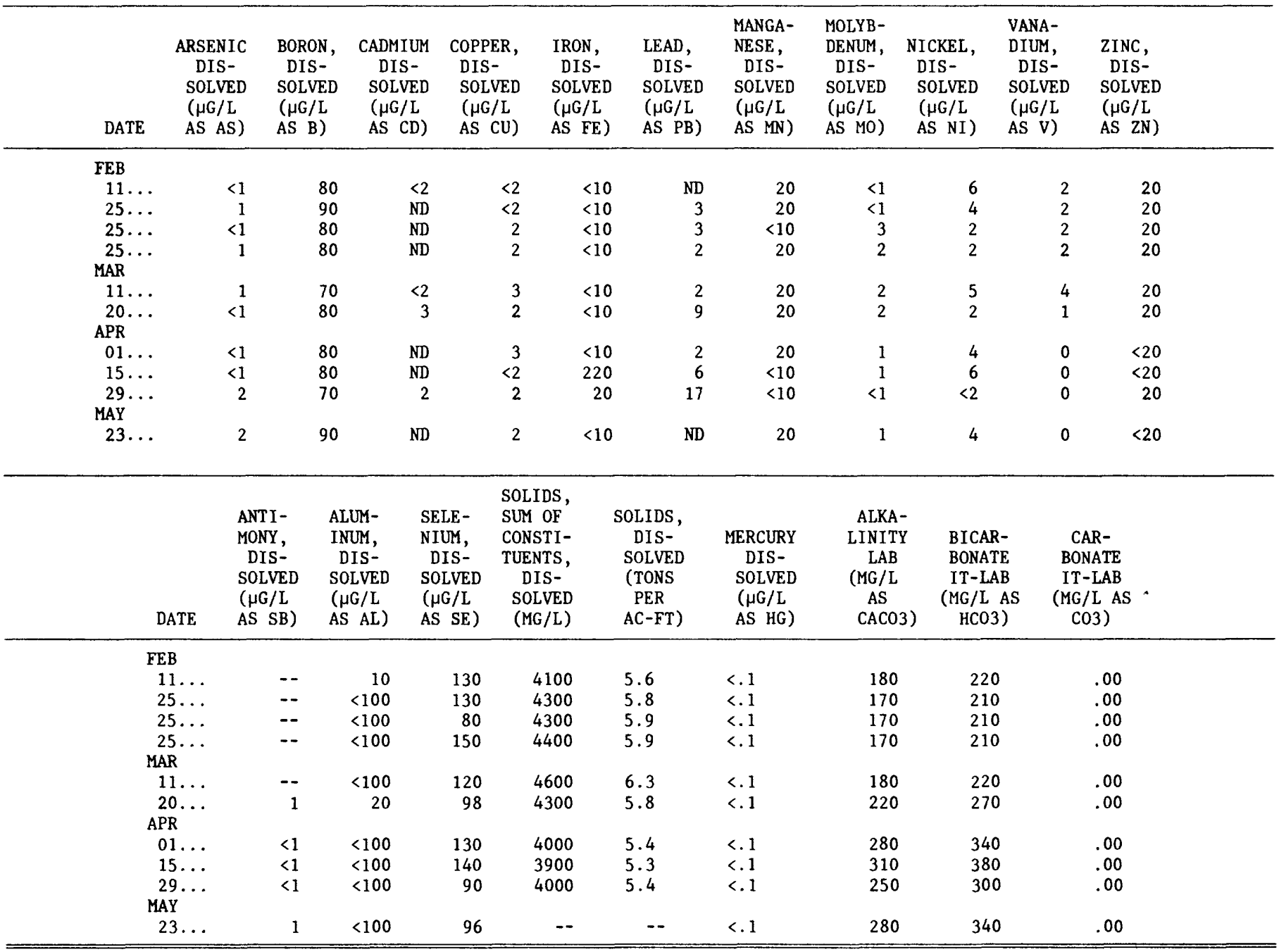


Table 8.--Water-quality data from Lysimeter 5--Continued

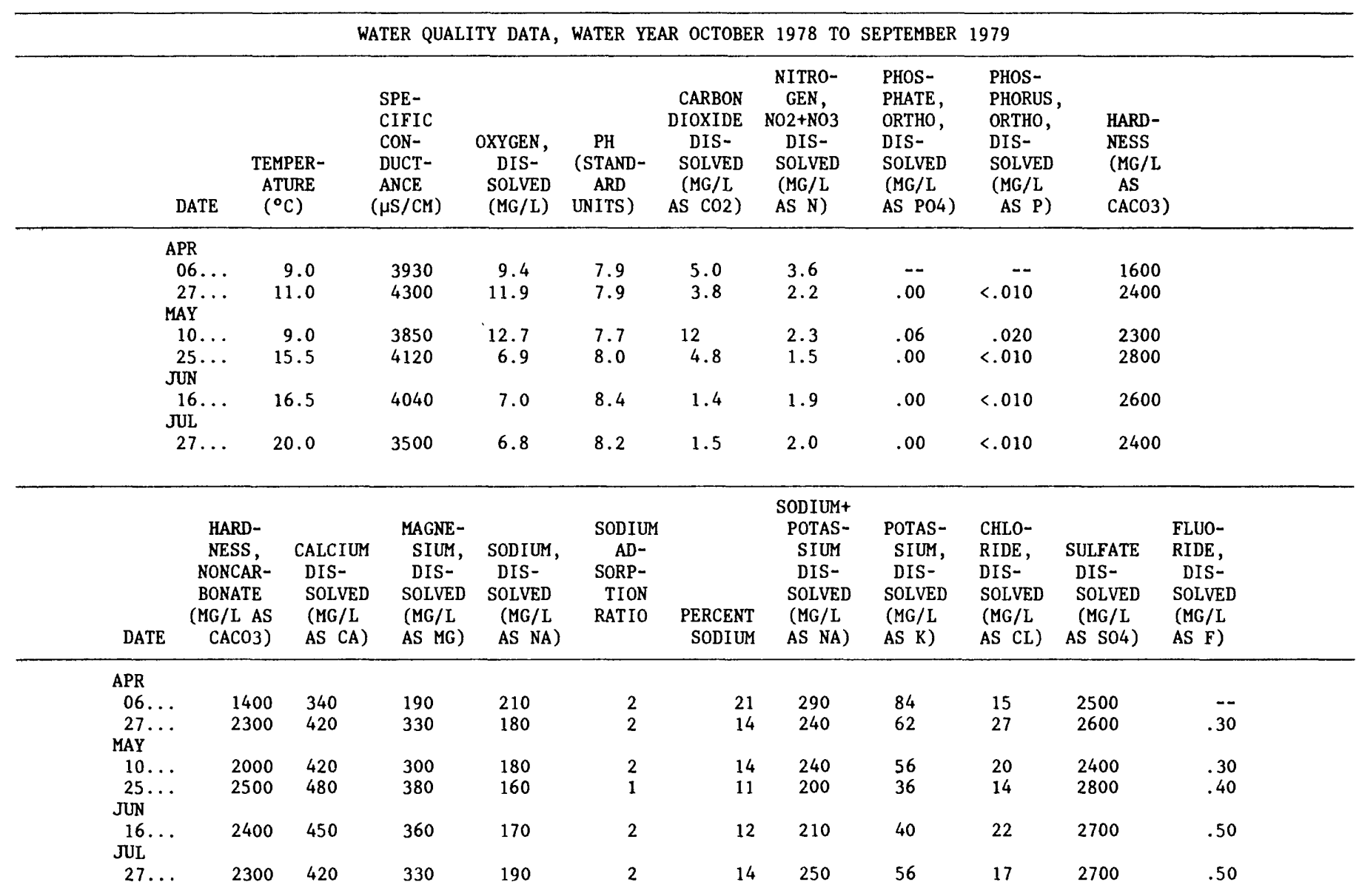


Table 8.--Water-quality data from Lysimeter 5--Continued

WATER QUALITY DATA, WATER YEAR OCTOBER 1978 TO SEPTEMBER 1979--Continued

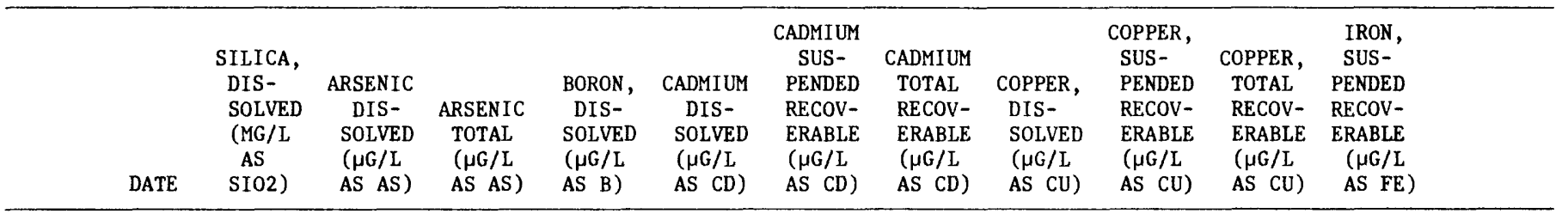

APR

$06 \ldots$
$27 .$.

8.9

1
$<1$
$<1$
$<1$
1
1

1
1
1
1
1
1

$\begin{array}{ll}60 & 3 \\ 70 & \text { ND } \\ 90 & \text { ND } \\ 80 & \text { ND } \\ 60 & \text { ND } \\ 80 & \text { ND }\end{array}$

$\begin{array}{ll}0 & <2 \\ 0 & \text { ND } \\ 1 & <2 \\ 0 & \text { ND } \\ 0 & \end{array}$

$\begin{array}{rrrrr}<2 & 2 & 3 & 5 & 0 \\ \text { ND } & <2 & 1 & 2 & 10 \\ <2 & \text { ND } & 2 & 2 & 20 \\ \text { ND } & \text { ND } & 8 & 8 & 10 \\ \text { ND } & \text { ND } & 2 & 2 & -- \\ \text { ND } & 2 & 1 & 3 & 80\end{array}$

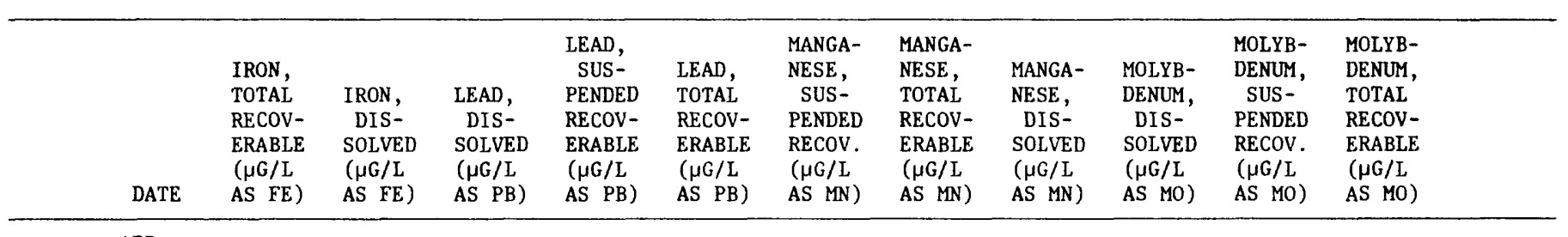

APR

\begin{tabular}{|c|c|c|c|c|c|c|c|c|c|c|c|}
\hline APR & & & & & & & & & & & \\
\hline $06 \ldots$ & 60 & 50 & ND & 12 & 12 & 10 & 20 & $<10$ & 1 & 4 & 5 \\
\hline $27 \ldots$ & 30 & 20 & ND & 7 & 7 & 0 & $<10$ & 20 & 2 & 2 & 4 \\
\hline MAY & & & & & & & & & & & \\
\hline $10 \ldots$ & 50 & 30 & ND & 11 & 11 & 0 & $<10$ & 20 & $<1$ & 0 & $<1$ \\
\hline $25 \ldots$ & 30 & 20 & 3 & 78 & 81 & 0 & $<10$ & $<10$ & $<1$ & 2 & 2 \\
\hline JUN & & & & & & & & & & & \\
\hline $16 \ldots$ & -- & 20 & ND & 11 & 11 & -- & -- & $<10$ & 1 & 0 & 1 \\
\hline JUL & & & & & & & & & & & \\
\hline $27 \ldots$ & 90 & $<10$ & ND & 5 & 5 & 0 & 20 & 20 & 2 & 0 & 1 \\
\hline
\end{tabular}


Table 8.--Water-quality data from Lysimeter 5--Continued

\begin{tabular}{|c|c|c|c|c|c|c|c|c|c|c|c|}
\hline \multirow[b]{2}{*}{ DATE } & \multirow[b]{2}{*}{$\begin{array}{l}\text { NICKEL, } \\
\text { DIS- } \\
\text { SOLVED } \\
(\mu G / L \\
\text { AS NI) }\end{array}$} & \multicolumn{3}{|c|}{ WATER QUALITY DATA, WATER } & \multicolumn{6}{|c|}{ YEAR OCTOBER 1978 TO SEPTEMBER 1979--Continued } & \multirow[b]{2}{*}{$\begin{array}{l}\text { SELE- } \\
\text { NIUM, } \\
\text { DIS- } \\
\text { SOLVED } \\
(\mu G / L \\
\text { AS SE) }\end{array}$} \\
\hline & & $\begin{array}{c}\text { NICKEL, } \\
\text { SUS- } \\
\text { PENDED } \\
\text { RECOV- } \\
\text { ERABLE } \\
(\mu G / L \\
\text { AS NI) }\end{array}$ & $\begin{array}{c}\text { NICKEL, } \\
\text { TOTAL } \\
\text { RECOV- } \\
\text { ERABLE } \\
(\mu G / L \\
\text { AS NI) }\end{array}$ & $\begin{array}{l}\text { VANA- } \\
\text { DIUM, } \\
\text { DIS- } \\
\text { SOLVED } \\
(\mu G / L \\
\text { AS V) }\end{array}$ & $\begin{array}{l}\text { ZINC, } \\
\text { DIS- } \\
\text { SOLVED } \\
(\mu G / L \\
\text { AS ZN) }\end{array}$ & $\begin{array}{l}\text { ZINC, } \\
\text { SUS- } \\
\text { PENDED } \\
\text { RECOV- } \\
\text { ERABLE } \\
(\mu G / L \\
\text { AS ZN) }\end{array}$ & $\begin{array}{l}\text { ZINC, } \\
\text { TOTAL } \\
\text { RECOV- } \\
\text { ERABLE } \\
(\mu G / L \\
\text { AS } Z N)\end{array}$ & $\begin{array}{l}\text { ALUM- } \\
\text { INUM, } \\
\text { TOTAL } \\
\text { RECOV- } \\
\text { ERABLE } \\
(\mu G / L \\
\text { AS AL) }\end{array}$ & $\begin{array}{l}\text { ALUM- } \\
\text { INUM, } \\
\text { DIS- } \\
\text { SOLVED } \\
(\mu G / L \\
\text { AS AL) }\end{array}$ & $\begin{array}{l}\text { ALUM- } \\
\text { INUM, } \\
\text { SUS- } \\
\text { PENDED } \\
\text { RECOV. } \\
(\mu G / L \\
\text { AS AL) }\end{array}$ & \\
\hline \multicolumn{12}{|l|}{ APR } \\
\hline $06 \ldots$ & 5 & 4 & 9 & -- & 40 & 0 & 50 & 50 & $<100$ & 50 & 200 \\
\hline \multicolumn{12}{|l|}{ MAY } \\
\hline $10 \ldots$ & ND & 6 & 6 & 1 & 20 & 10 & 30 & 110 & 20 & 90 & 230 \\
\hline \multicolumn{12}{|l|}{ JUN } \\
\hline \multicolumn{12}{|l|}{ JUL } \\
\hline $27 \ldots$ & 3 & 4 & 7 & $<1$ & $<20$ & 20 & 30 & 140 & $<100$ & 140 & 200 \\
\hline DATE & $\begin{array}{l}\text { SELE- } \\
\text { NIUM, } \\
\text { SUS- } \\
\text { PENDED } \\
\text { TOTAL } \\
(\mu G / L \\
\text { AS SE) }\end{array}$ & $\begin{array}{l}\text { SELE- } \\
\text { NIUM, } \\
\text { TOTAL } \\
\text { ( } \mu G / L \\
\text { AS SE) }\end{array}$ & $\begin{array}{c}\text { SOLIDS, } \\
\text { SUM OF } \\
\text { CONSTI- } \\
\text { TUENTS, } \\
\text { DIS- } \\
\text { SOLVED } \\
\text { (MG/L) }\end{array}$ & $\begin{array}{c}\text { SOLIDS, } \\
\text { DIS- } \\
\text { SOLVED } \\
\text { (TONS } \\
\text { PER } \\
\text { AC-FT) }\end{array}$ & $\begin{array}{c}\text { MERCURY } \\
\text { DIS- } \\
\text { SOLVED } \\
(\mu G / L \\
\text { AS HG) }\end{array}$ & $\begin{array}{c}\text { MERCURY } \\
\text { SUS- } \\
\text { PENDED } \\
\text { RECOV- } \\
\text { ERABLE } \\
(\mu G / L \\
\text { AS HG) }\end{array}$ & & $\begin{array}{l}\text { RCURY } \\
\text { OTAL } \\
\text { ECOV- } \\
\text { RABLE } \\
\text { MG /L } \\
\text { S HG) }\end{array}$ & $\begin{array}{c}\text { ALKA- } \\
\text { LINITY } \\
\text { LAB } \\
\text { (MG/L } \\
\text { AS } \\
\text { CACO3) }\end{array}$ & $\begin{array}{l}\text { BICAR- } \\
\text { BONATE } \\
\text { IT-LAB } \\
\text { (MG/L AS } \\
\text { HCO3) }\end{array}$ & $\begin{array}{c}\text { CAR- } \\
\text { BONATE } \\
\text { IT-LAB } \\
\text { (MG/L AS } \\
\text { C03) }\end{array}$ \\
\hline \multicolumn{12}{|l|}{ APR } \\
\hline $06 \ldots$ & 0 & 190 & 3500 & 4.8 & $<.1$ & -- & & -- & 210 & 250 & .00 \\
\hline \multicolumn{12}{|l|}{ MAY } \\
\hline $10 \ldots$ & 0 & 230 & 3600 & 4.9 & $<.1$ & .1 & & $<.1$ & 300 & 370 & .00 \\
\hline \multicolumn{12}{|l|}{ JUN } \\
\hline JUL & \multicolumn{9}{|c|}{ JUL } & 200 & 1.0 \\
\hline $27 \ldots$ & 10 & 210 & 3800 & 5.2 & $<.1$ & .0 & & $<.1$ & 120 & 150 & .00 \\
\hline
\end{tabular}


Table 8.--Water-quality data from Lysimeter 5--Continued

WATER QUALITY DATA, WATER YEAR OCTOBER 1979 TO SEPTEMBER 1980

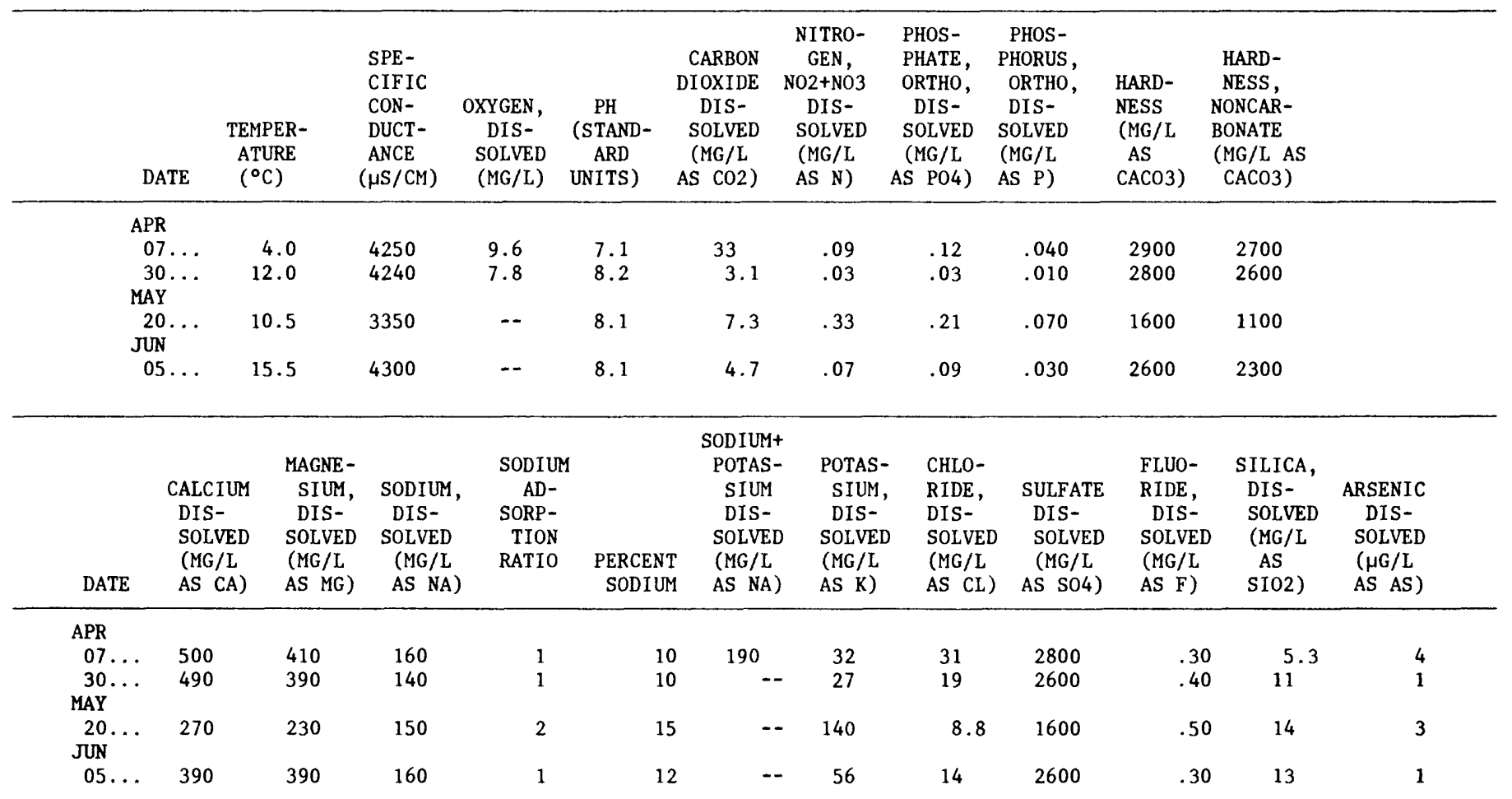


Table 8.--Water-quality data from Lysimeter 5--Continued

WATER QUALITY DATA, WATER YEAR OCTOBER 1979 TO SEPTEMBER 1980--Continued

\begin{tabular}{|c|c|c|c|c|c|c|c|c|c|c|c|}
\hline DATE & $\begin{array}{l}\text { BORON, } \\
\text { DIS- } \\
\text { SOLVED } \\
(\mu \mathrm{G} / \mathrm{L} \\
\text { AS B) }\end{array}$ & $\begin{array}{l}\text { CADMIUM } \\
\text { DIS- } \\
\text { SOLVED } \\
(\mu G / L \\
\text { AS CD) }\end{array}$ & $\begin{array}{l}\text { COPPER, } \\
\text { DIS- } \\
\text { SOLVED } \\
(\mu G / L \\
\text { AS CU) }\end{array}$ & $\begin{array}{l}\text { IRON, } \\
\text { SUS- } \\
\text { PENDED } \\
\text { RECOV- } \\
\text { ERABLE } \\
(\mu G / L \\
\text { AS FE) }\end{array}$ & $\begin{array}{l}\text { IRON, } \\
\text { TOTAL } \\
\text { RECOV- } \\
\text { ERABLE } \\
(\mu G / L \\
\text { AS FE) }\end{array}$ & $\begin{array}{l}\text { IRON, } \\
\text { DIS- } \\
\text { SOLVED } \\
(\mu \mathrm{G} / \mathrm{L} \\
\text { AS FE) }\end{array}$ & $\begin{array}{l}\text { LEAD, } \\
\text { DIS- } \\
\text { SOLVED } \\
(\mu \mathrm{G} / \mathrm{L} \\
\text { AS PB) }\end{array}$ & $\begin{array}{l}\text { MANGA- } \\
\text { NESE, } \\
\text { SUS- } \\
\text { PENDED } \\
\text { RECOV. } \\
(\mu G / L \\
\text { AS MN) }\end{array}$ & $\begin{array}{l}\text { JGA- } \\
\text { CA, } \\
\text { CAL } \\
\text { COV- } \\
\text { ALE } \\
\text { J/L } \\
\text { MN) }\end{array}$ & $\begin{array}{l}\text { MANGA- } \\
\text { NESE, } \\
\text { DIS- } \\
\text { SOLVED } \\
\text { ( } \mu G / L \\
\text { AS MN) }\end{array}$ & $\begin{array}{l}\text { MOLYB- } \\
\text { DENUM, } \\
\text { DIS- } \\
\text { SOLVED } \\
(\mu \mathrm{G} / \mathrm{L} \\
\text { AS MO) }\end{array}$ \\
\hline \multicolumn{12}{|l|}{ APR } \\
\hline $07 \ldots$ & 70 & 0 & 1 & 10 & 50 & 40 & 2 & 10 & 20 & 10 & 2 \\
\hline $30 \ldots$ & 70 & 0 & 1 & 60 & 100 & 40 & 0 & 0 & 10 & 20 & 0 \\
\hline \multicolumn{12}{|l|}{ MAY } \\
\hline & \multicolumn{10}{|c|}{ JUN } & 1 \\
\hline $05 \ldots$ & 100 & 0 & 4 & 70 & 100 & 30 & 2 & 0 & 10 & 20 & 1 \\
\hline DATE & $\begin{array}{l}\text { NICKEL, } \\
\text { DIS- } \\
\text { SOLVED } \\
(\mu G / L \\
\text { AS NI) }\end{array}$ & $\begin{array}{l}\text { VANA- } \\
\text { DIUM, } \\
\text { DIS- } \\
\text { SOLVED } \\
(\mu G / L \\
\text { AS V) }\end{array}$ & $\begin{array}{l}\text { ZINC, } \\
\text { DIS- } \\
\text { SOLVED } \\
(\mu G / L \\
\text { AS ZN) }\end{array}$ & $\begin{array}{l}\text { ALUM- } \\
\text { INUM, } \\
\text { DIS- } \\
\text { SOLVED } \\
(\mu G / L \\
\text { AS AL) }\end{array}$ & $\begin{array}{l}\text { SELE- } \\
\text { NIUM, } \\
\text { DIS- } \\
\text { SOLVED } \\
(\mu G / L \\
\text { AS SE) }\end{array}$ & $\begin{array}{c}\text { SOLIDS, } \\
\text { SUM OF } \\
\text { CONSTI- } \\
\text { TUENTS, } \\
\text { DIS- } \\
\text { SOLVED } \\
\text { (MG/L) }\end{array}$ & $\begin{array}{l}\text { SOLIDS, } \\
\text { DIS- } \\
\text { SOLVED } \\
\text { (TONS } \\
\text { PER } \\
\text { AC-FT) }\end{array}$ & $\begin{array}{l}\text { MERCURY } \\
\text { DIS- } \\
\text { SOLVED } \\
(\mu \mathrm{G} / \mathrm{L} \\
\text { AS HG) }\end{array}$ & & $\begin{array}{c}\text { ALKA- } \\
\text { LINITY } \\
\text { LAB } \\
\text { (MG/L } \\
\text { AS } \\
\text { CACO3) }\end{array}$ & $\begin{array}{c}\text { BICAR- } \\
\text { BONATE } \\
\text { IT-LAB } \\
\text { (MG/L AS } \\
\text { HCO3) }\end{array}$ \\
\hline \multicolumn{12}{|l|}{ APR } \\
\hline $07 \ldots$ & 7 & 1 & 0 & 20 & 210 & 4100 & 5.5 & .0 & & 210 & 256 \\
\hline${ }_{\text {MAY }}^{30 . . .}$ & 5 & 1 & 10 & 40 & 200 & 3800 & 5.2 & .0 & & 250 & 305 \\
\hline$\underset{\text { JUN }}{20} \ldots$ & 5 & 20 & 50 & 30 & 100 & 2700 & 3.7 & .0 & & 470 & 573 \\
\hline $05 \ldots$ & 6 & 7 & 20 & 20 & 130 & 3800 & 5.2 & .0 & & 300 & 366 \\
\hline
\end{tabular}


Table 9.--Water-quality data from Yampa River above Hayden, first application each day

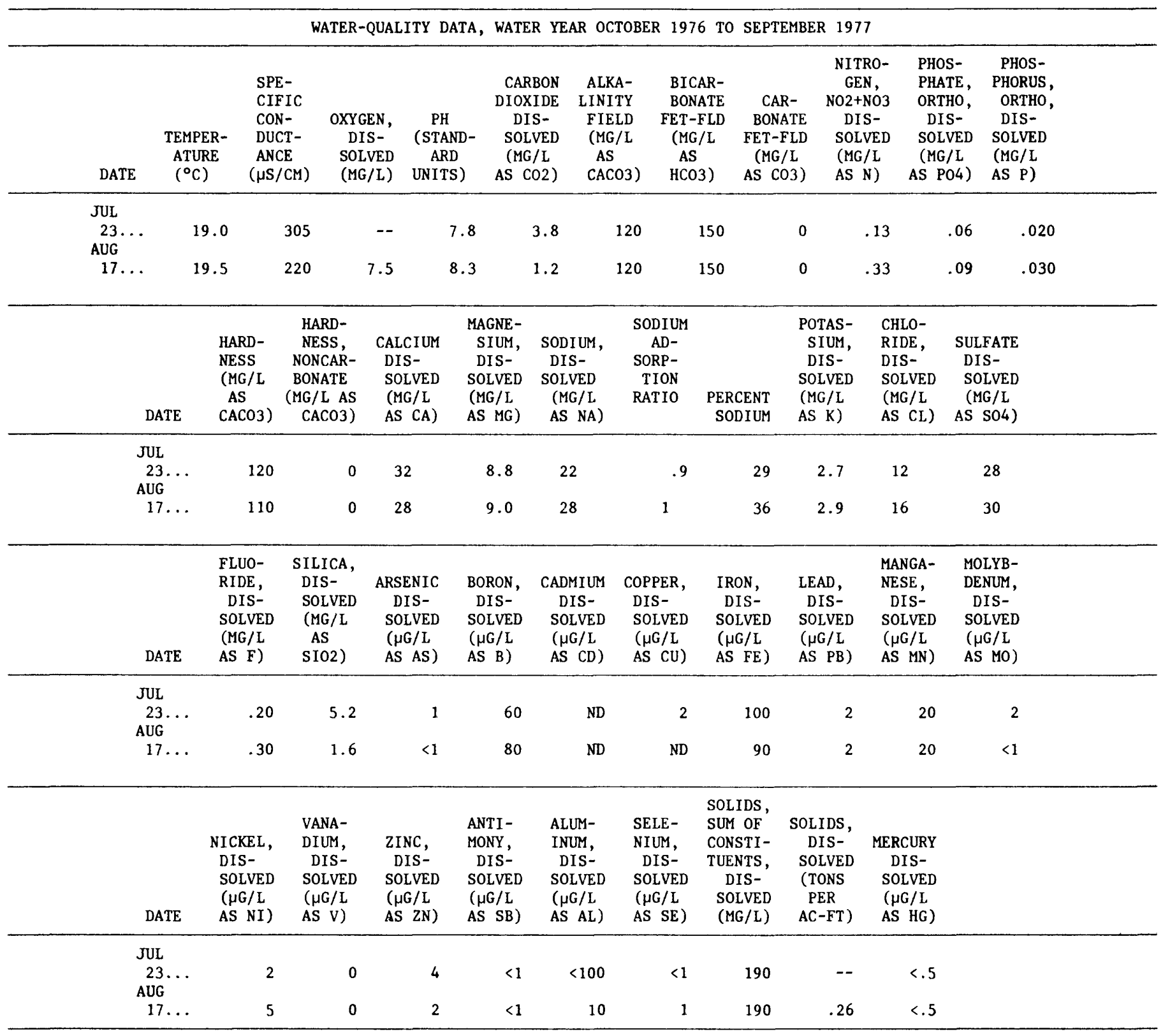


Table 10.--Water-quality data from Yampa River above Hayden, second application each day

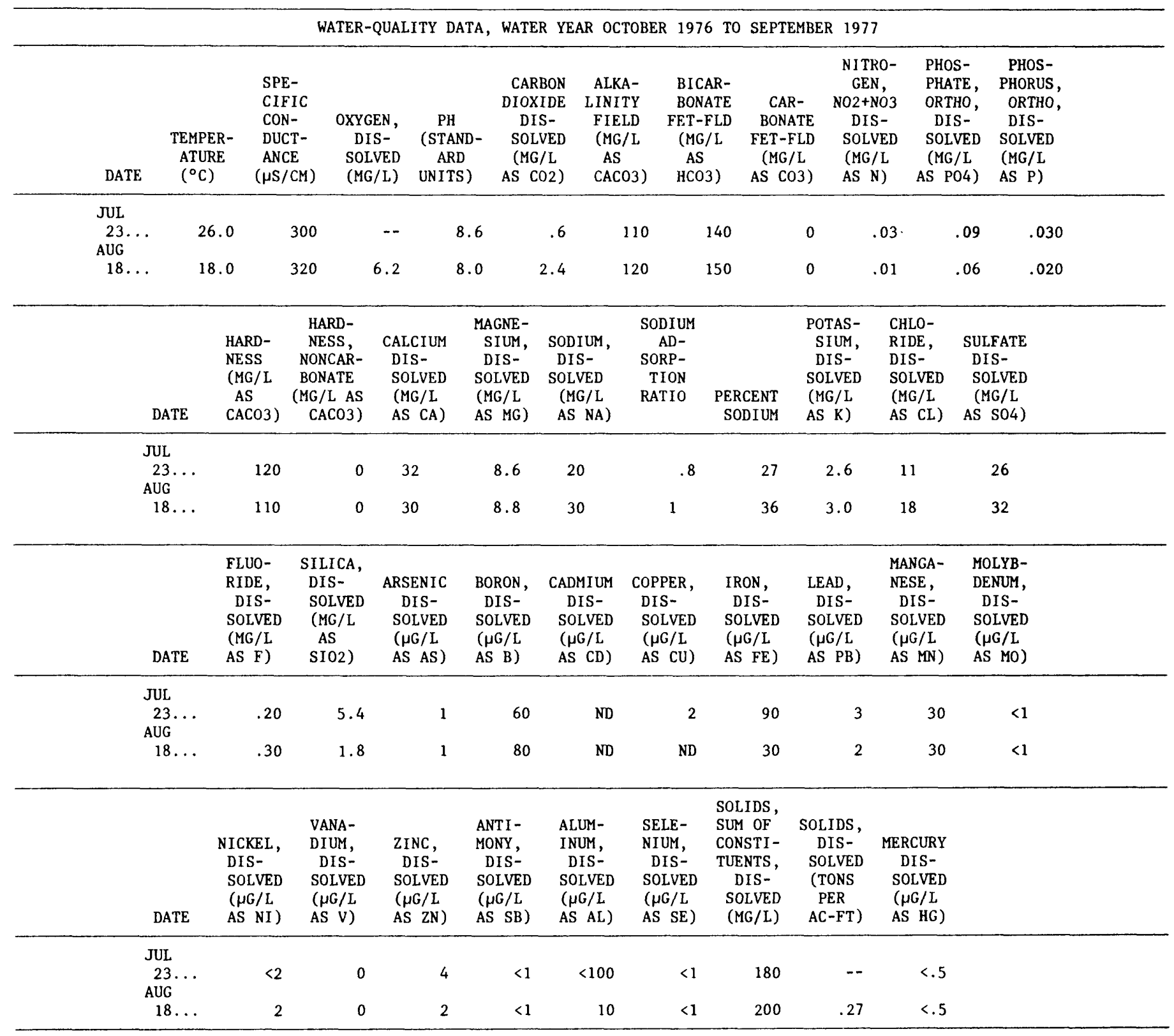


Table 11.--Water-quality data from Yampa River above Hayden, third application each day

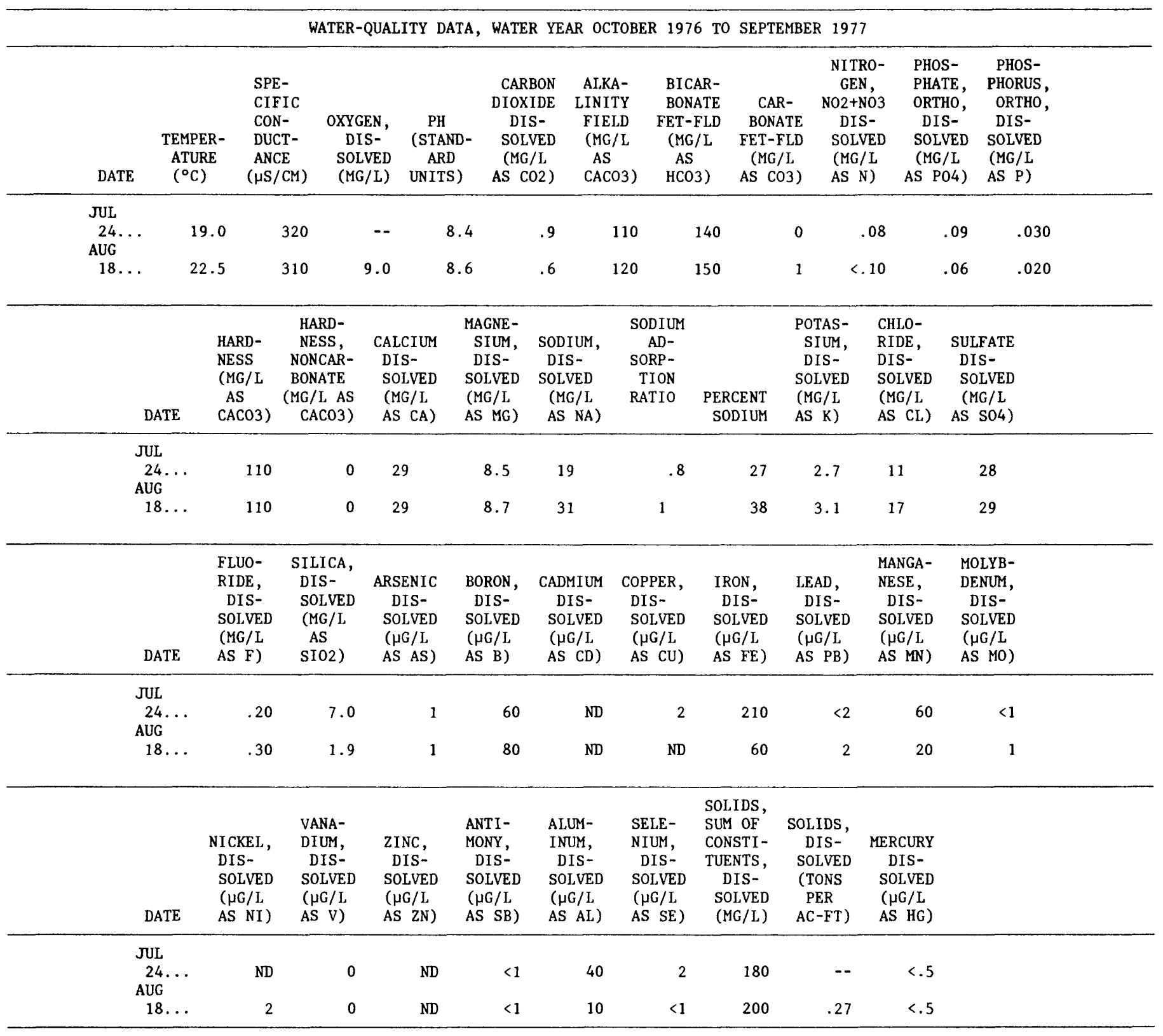


Table 12.--Water-quality data from Yampa River above Hayden, fourth application each day

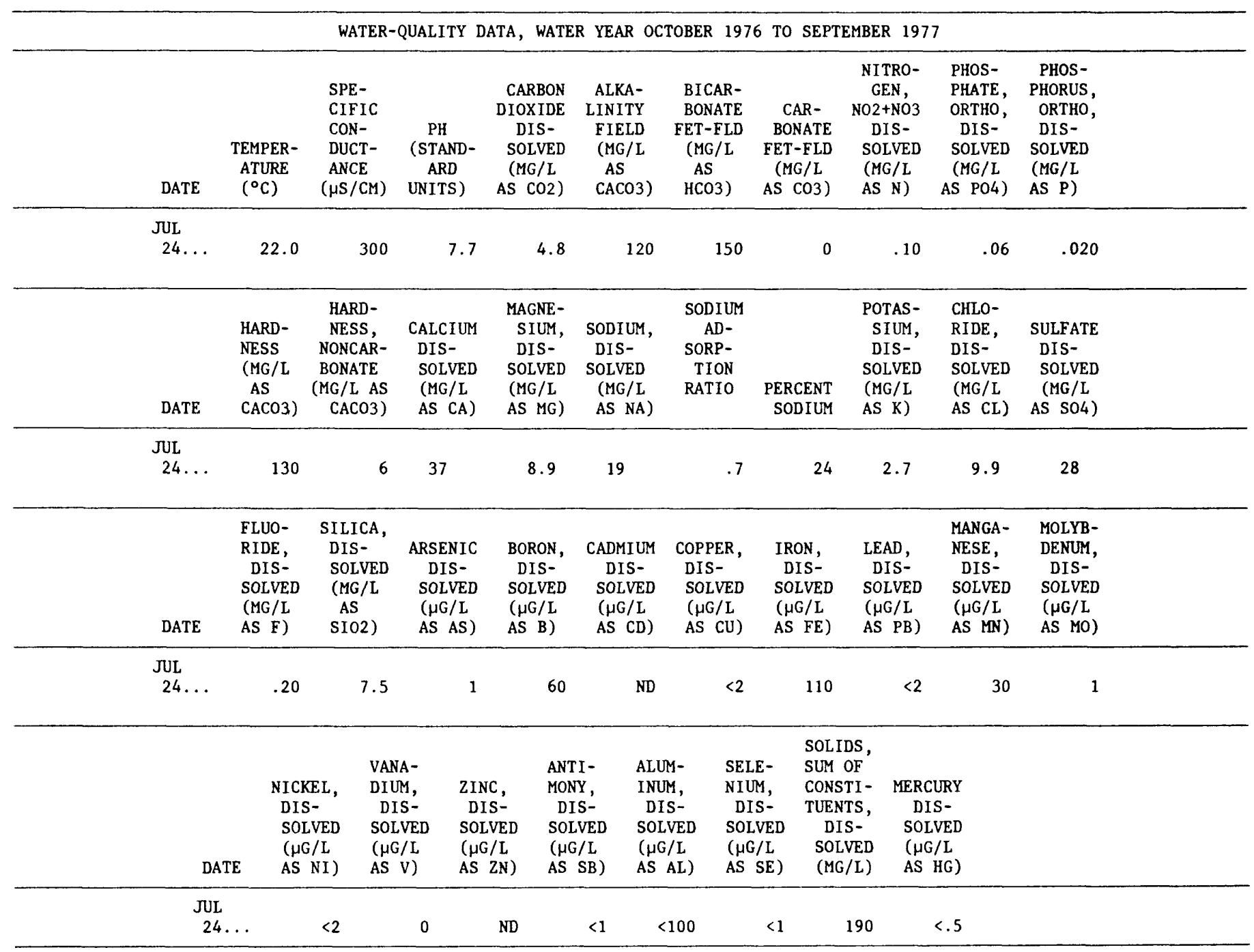


Table 13.--Water-quality data from Yampa River above Hayden, fifth application each day WATER-QUALITY DATA, WATER YEAR OCTOBER 1976 TO SEPTEMBER 1977

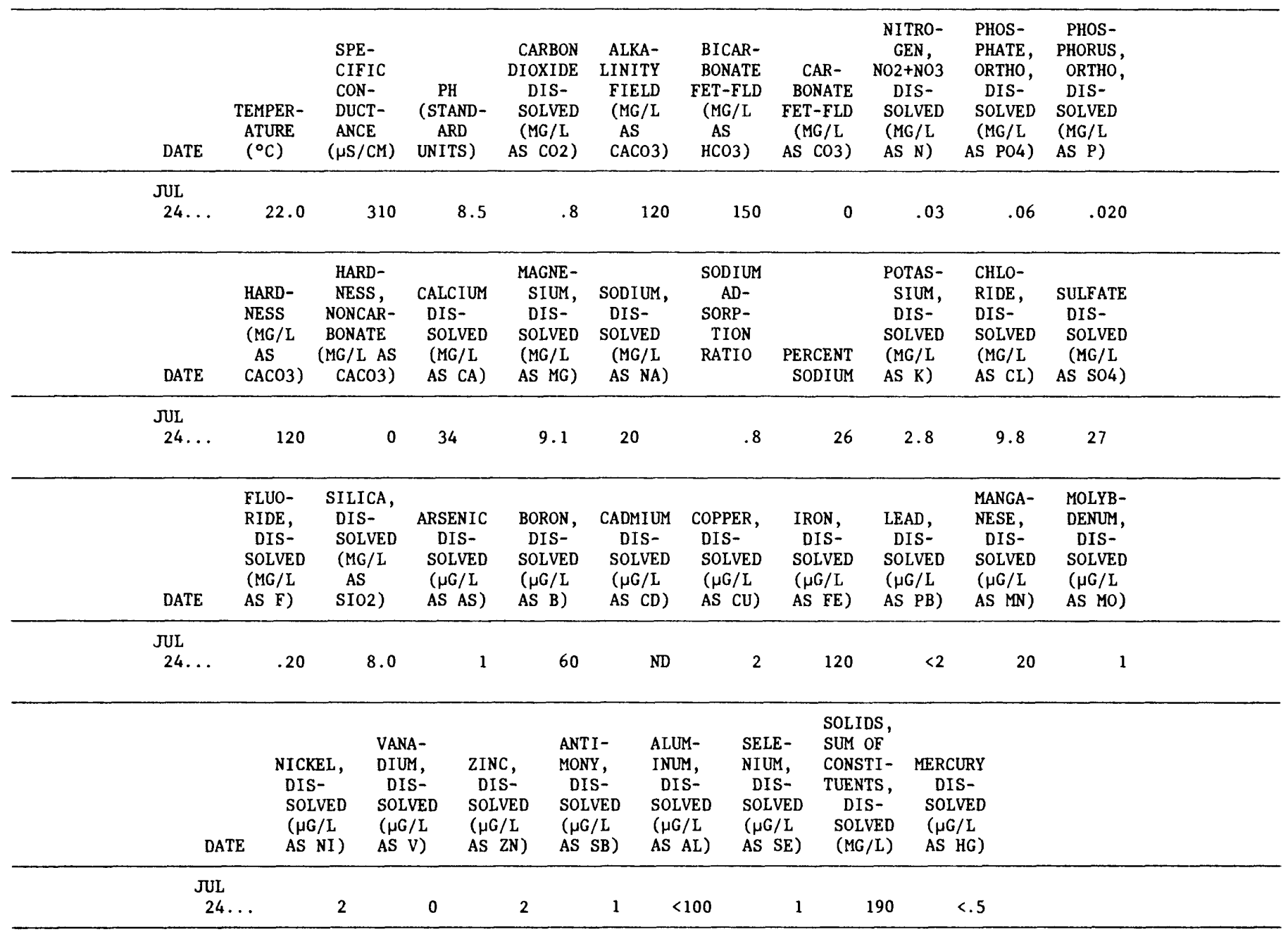


Table 14.--Water-quality data from Yampa River water, after transportation to lysimeter site, first application each day

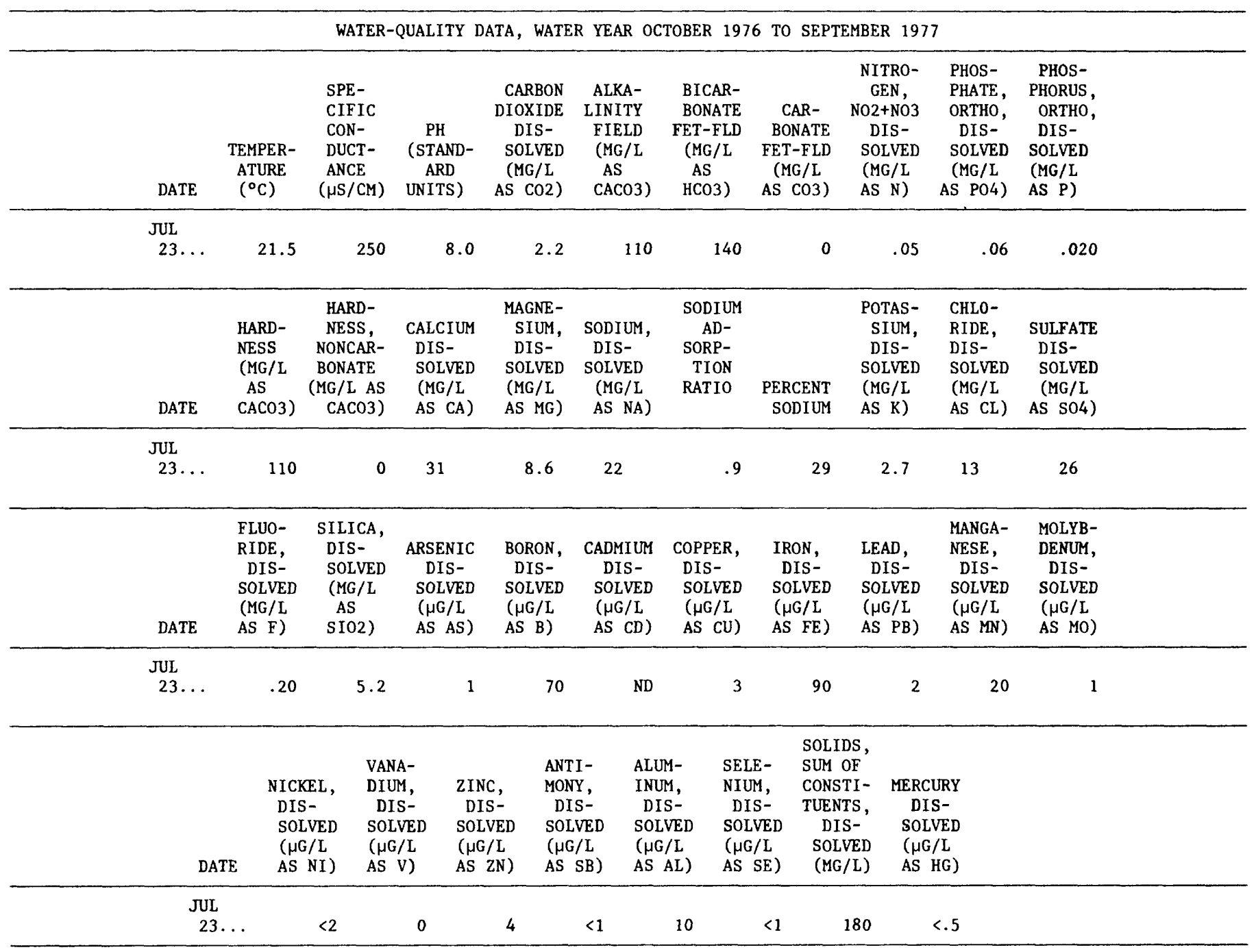


Table 15.--Water-quality data from Yampa River water, after transportation to lysimeter site, second application each day

WATER-QUALITY DATA, WATER YEAR OCTOBER 1976 TO SEPTEMBER 1977

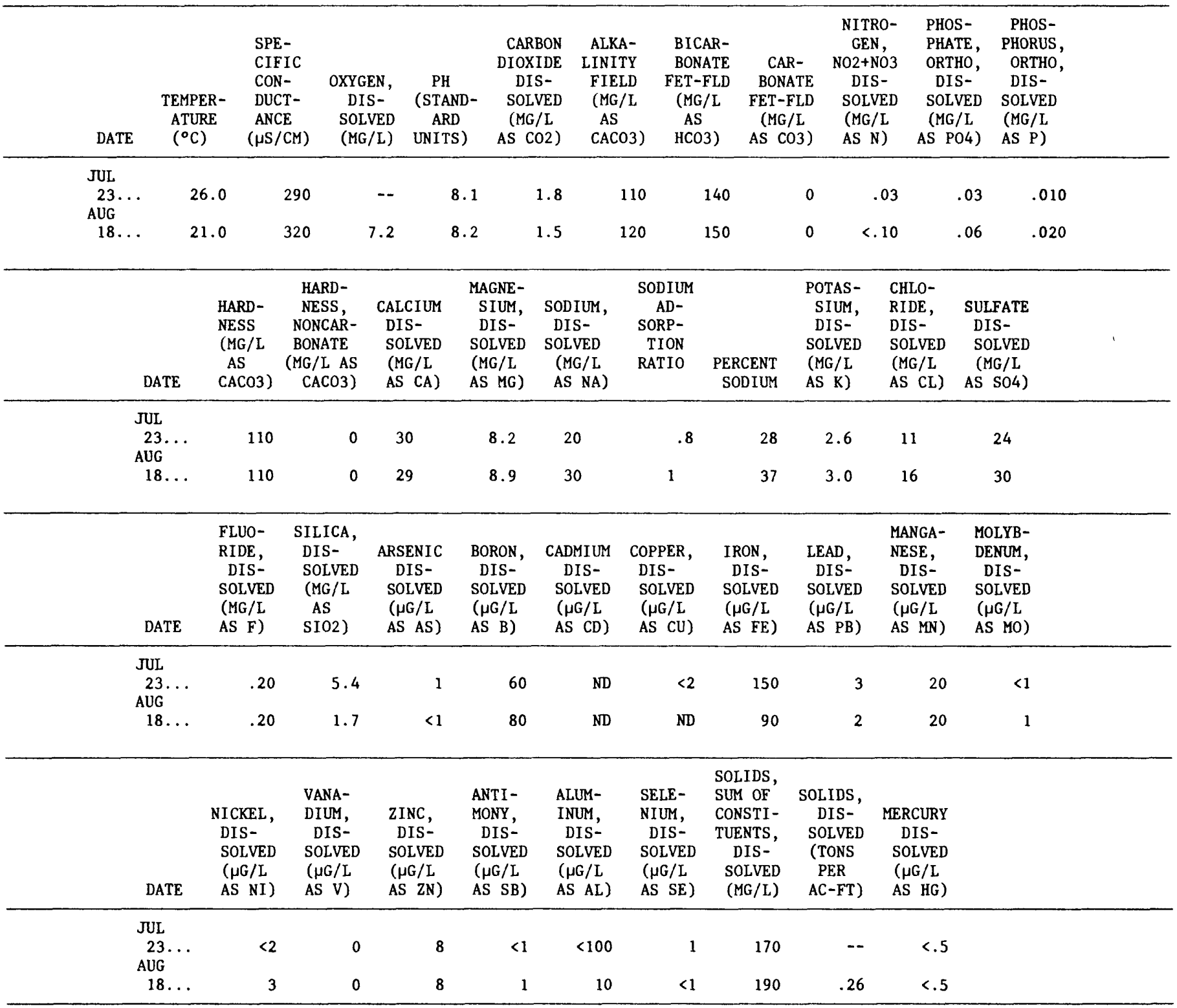


Table 16.--Water-quality data from Yampa River water, after transportation to lysimeter site, third application each day

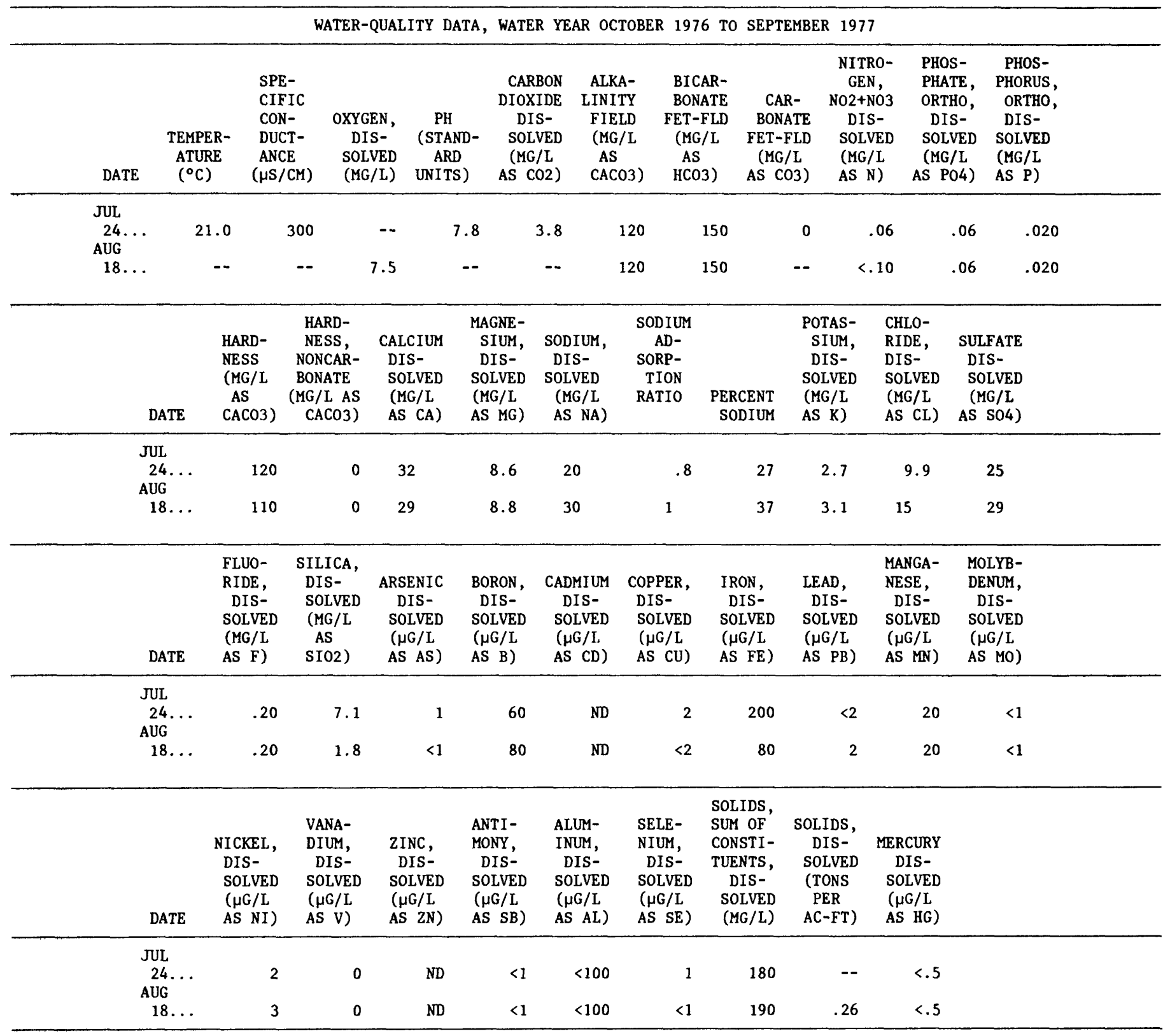


Table 17.--Water-quality data from Yampa River water, after transportation to Iysimeter site, fourth application each day

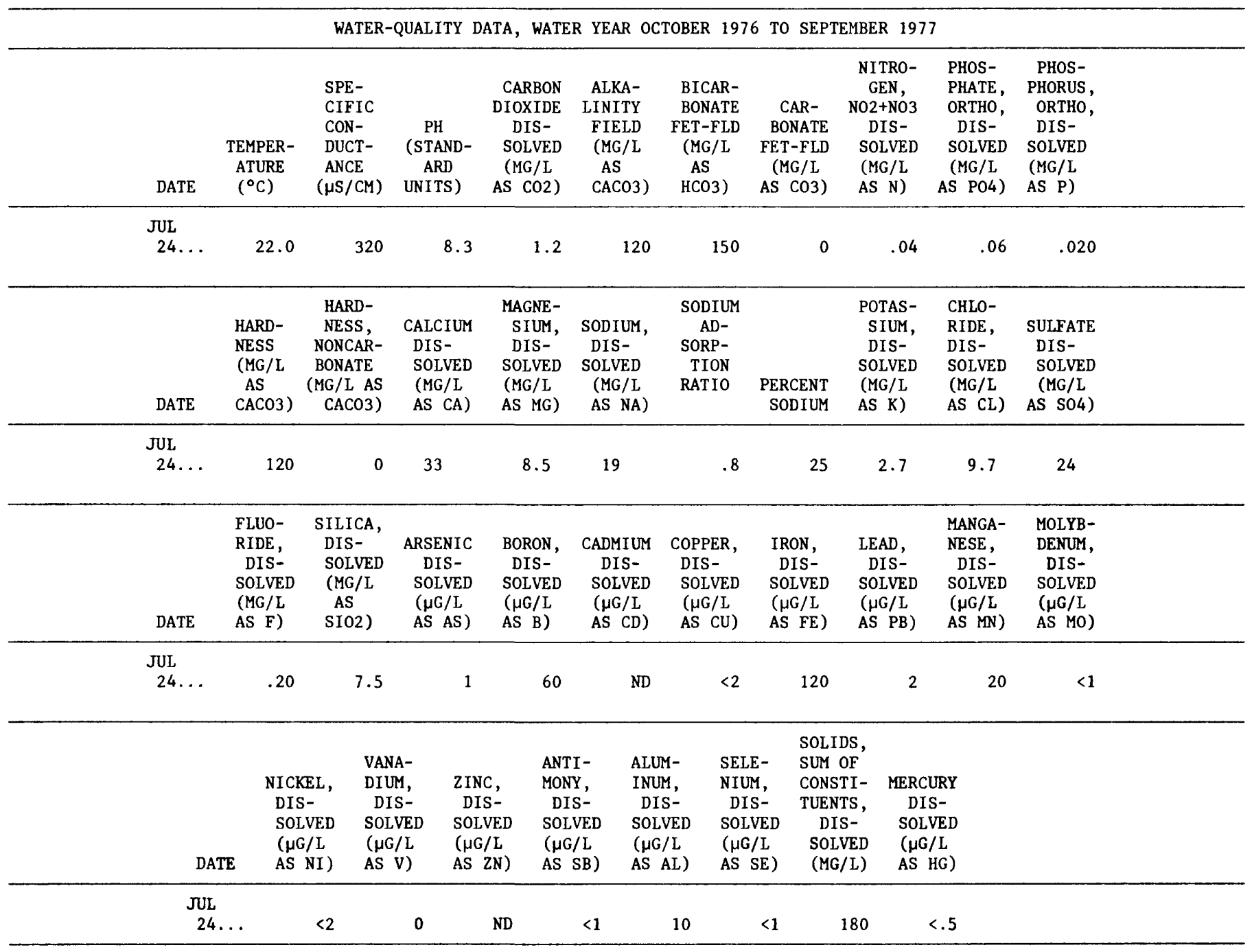


Table 18.--Water-quality data from Yampa River water, after transportation to lysimeter site, fifth application each day

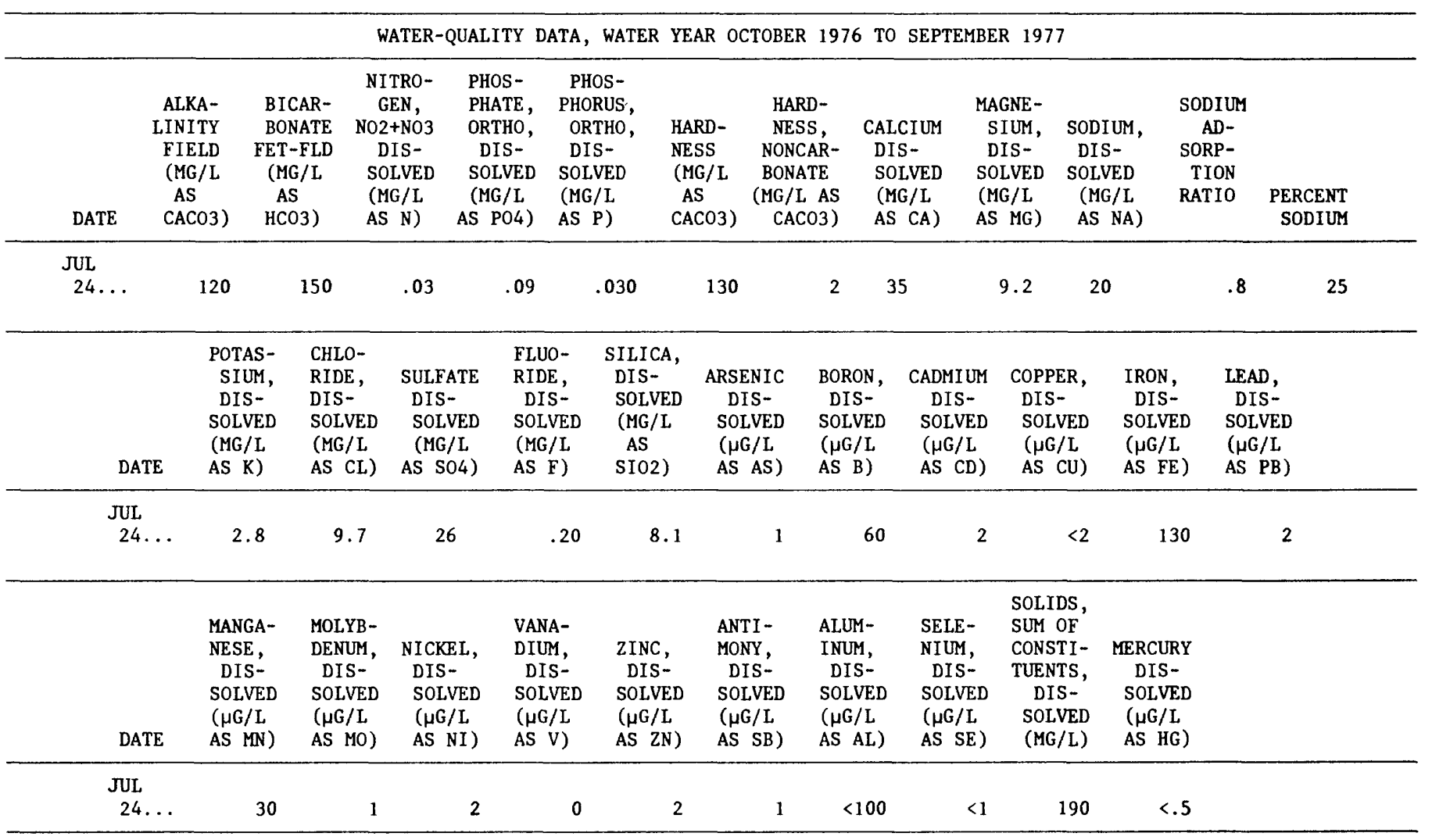




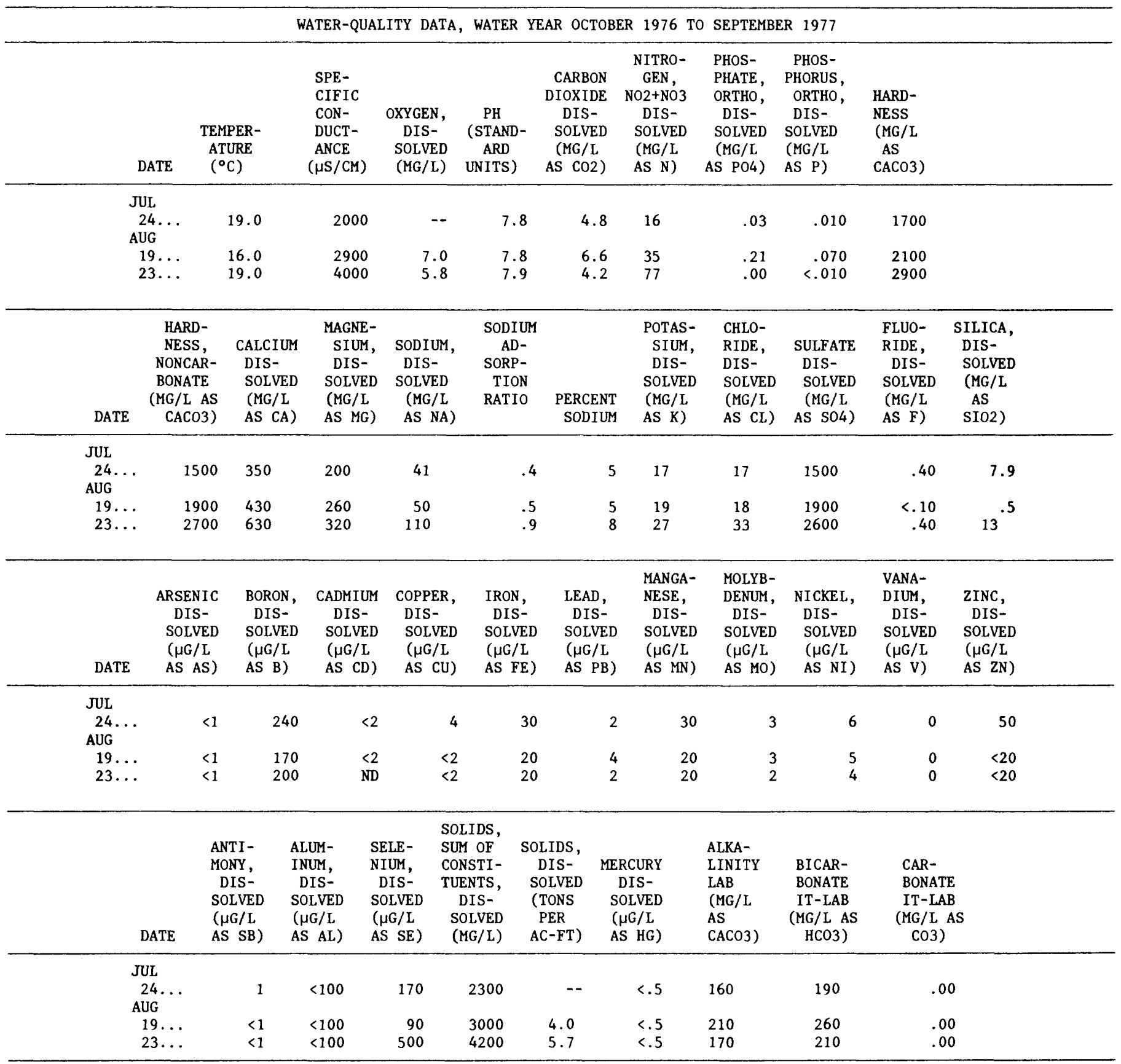


Table 20.--Water-quality data from lysimeter 3 following water application

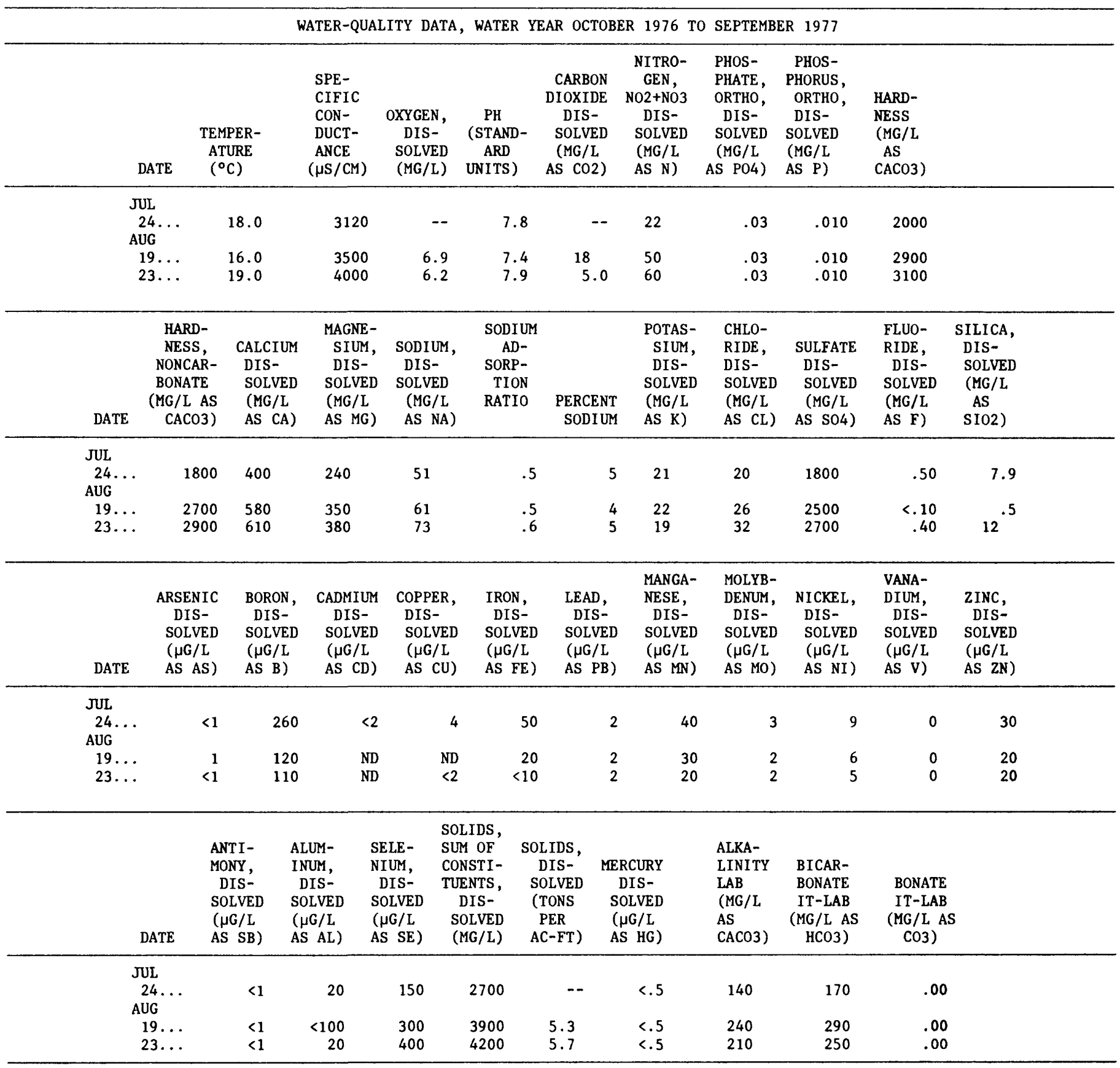


Table 21.--Water-quality data from lysimeter 4 following water application

WATER-QUALITY DATA, WATER YEAR OCTOBER 1976 TO SEPTEMBER 1977

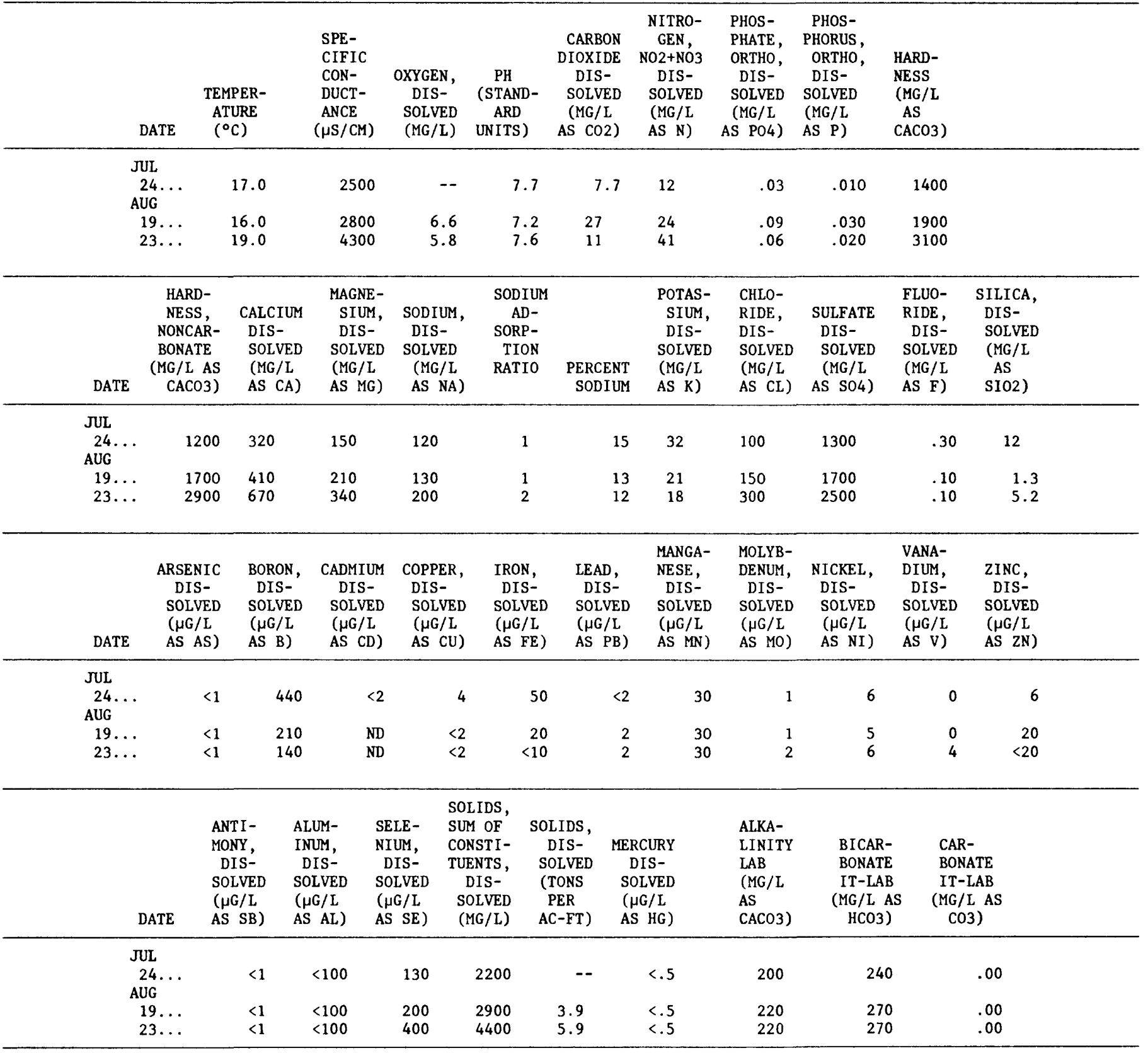


Table 22.--Water-quality data from lysimeter 5 following water application

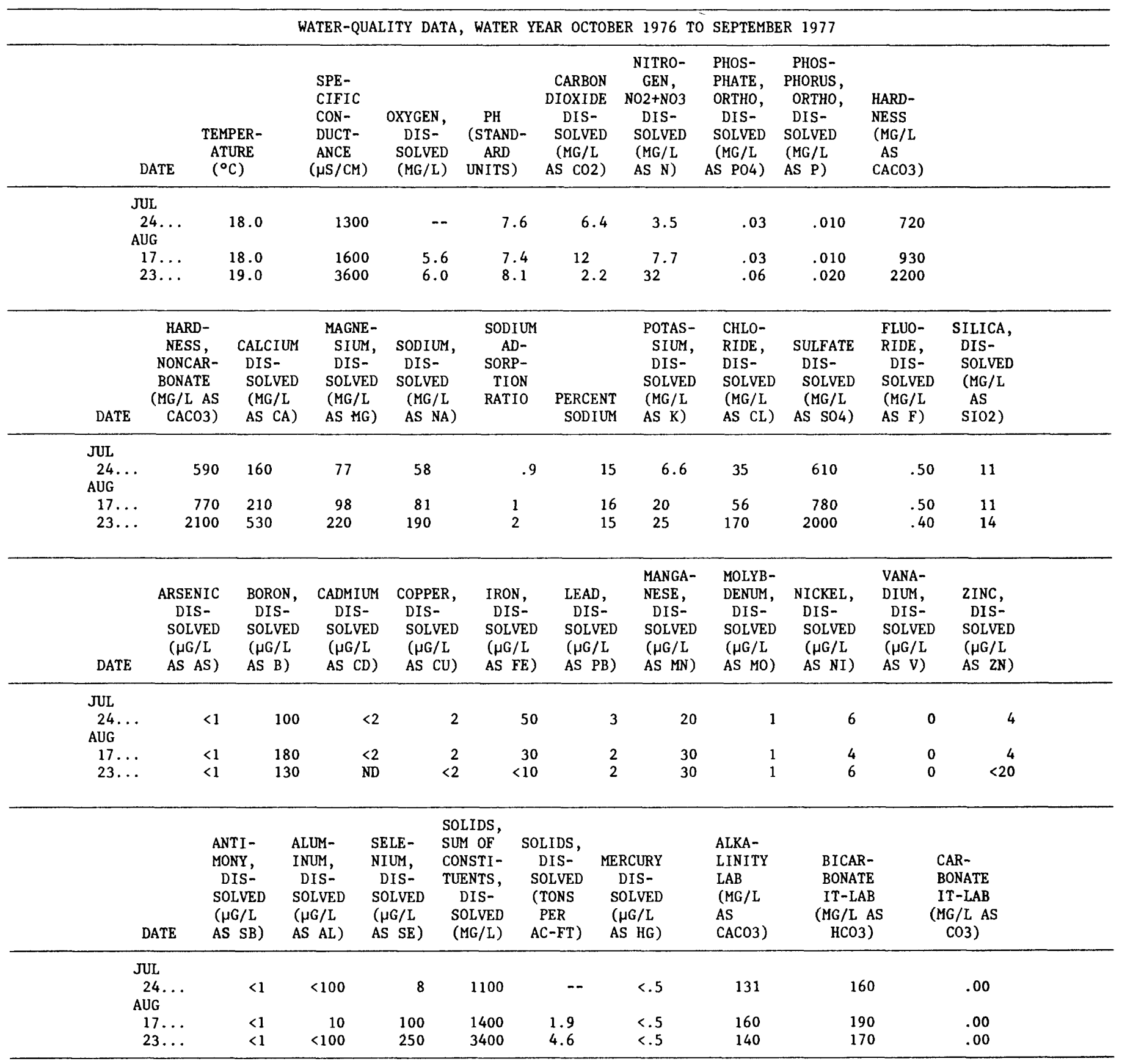

